Klonierung und Charakterisierung des Interleukin-1 $\beta$-Systems im Gehirn von Callithrix jacchus

\author{
Dissertation \\ zur Erlangung des Doktorgrades \\ der Mathematisch-Naturwissenschaftlichen Fakultäten \\ der Georg-August-Universität zu Göttingen
}

\author{
vorgelegt von \\ Christiane Köster-Patzlaff, \\ geb. Köster \\ aus Papenburg
}

Göttingen 2003 
D 7

Referent: $\quad$ Prof. Dr. R. Hustert

Korreferent: Prof. Dr. I. Balzer

Tag der mündlichen Prüfung: 03.07.2003 
Meinen Eltern

\& Clemens 


\section{Abkürzungsverzeichnis}

A

Abb.

ACTH

$\mathrm{Ak}$

Amp.

AP

AS

BCIP

BIO-ULS $^{\circledR}$

bp

bzw.

$\mathrm{C}$

${ }^{\circ} \mathrm{C}$

ca.

cDNA

C. jacchus

$\mathrm{cm}$

CRF

ct

$\mathrm{DAB}+$

d.h.

dig

DNA

DNAse

dNTP

DPZ

dsDNA

E. coli

ELISA

et al.

$\mathrm{EtOH}$

FAM
Argenin

Abbildung

Adreno-Corticotropes-Hormon

Antikörper

Ampicillin

Alkalische Phosphatase

antisense

Bromchorindolphosphat

Biotin-Universal-Link-System ULYSIS ${ }^{\circledR}$

Basenpaar

beziehungsweise

Cytosin

Grad Celsius

circa

komplementäre Desoxyribonukleinsäure

Callithrix jacchus

Zentimeter

Corticotropin-Releasing-Faktor

gemessene Emission

Diaminobenzidin Plus

das heißt

Digoxigenin

Desoxyribonukleinsäure

Desoxyribonuklease

Basen-Mix

Deutsches Primatenzentrum

doppelsträngige Desoxiribonukleinsäure

Escherichia coli

Enzym-linked-Immunosorbent-Assay

et alteri

Ethanol

Reporter-Farbstoff 


\begin{tabular}{|c|c|}
\hline FCS & Fetales Kälberserum \\
\hline FRET & Fluoreszenz-Resonanz-Energietransfer \\
\hline FSH & Follikel stimulierendes Hormon \\
\hline $\mathrm{g}$ & Gramm \\
\hline G & Guanin \\
\hline GFAP & Glial-Fibrillary-Acidic-Protein \\
\hline $\mathrm{GH}$ & Wachstumshormon \\
\hline GnRH & Gonadotropin-Releasing Hormon \\
\hline $\mathrm{h}$ & Stunde \\
\hline $\mathrm{HCl}$ & Salzsäure \\
\hline $\mathrm{HE}$ & Hämatoxilin-Eosin \\
\hline $\mathrm{H}_{2} \mathrm{O}_{2}$ & Wasserstoffperoxid \\
\hline HRP & Meerrettich-Peroxidase \\
\hline $\mathrm{IHC}$ & Immunhistochemie \\
\hline IL-1 $\beta$ & Interleukin-1 beta \\
\hline IL-1ra & Interleukin-1 Rezeptor Antagonist \\
\hline IL-1RI & Interleukin-1 Rezeptor Typ I \\
\hline IL-1RII & Interleukin-1 Rezeptor Typ II \\
\hline IL-2 & Interleukin-2 \\
\hline IL-4 & Interleukin-4 \\
\hline IL-6 & Interleukin-6 \\
\hline i.m. & intramuskulär \\
\hline IRMA & Immunradiometrischer Assay \\
\hline ISH & in-situ-Hybridisierung \\
\hline 1 & Liter \\
\hline LB & Luria-Bertani-Medium \\
\hline LH & luteinisierendes Hormon \\
\hline $\mathrm{LiCl}$ & Liciumchlorid \\
\hline LPS & Lipopolysaccharid \\
\hline MAk & monoklonaler Antikörper \\
\hline M & molar \\
\hline $\mathrm{m}$ & milli \\
\hline $\min$ & Minute \\
\hline $\mathrm{mM}$ & milliMol \\
\hline
\end{tabular}




\begin{tabular}{|c|c|}
\hline M-MLV RT & murine retrovirale Reverse Transkriptase \\
\hline MOPS & 3-(N-Morpholino)propanesulfonicacid \\
\hline mRNA & messenger (Boten-) Ribonukeinsäure \\
\hline $\mathrm{N}$ & Stickstoff \\
\hline $\mathrm{NaCl}$ & Natriumchlorid \\
\hline NBT & Nirtoblautetrazoliumchlorid \\
\hline $\mathrm{n}$ & nano \\
\hline NSB & nicht-spezifische Bindungen \\
\hline NSE & Neuronspezifische Enolase \\
\hline NTC & Leerwert ohne Probe \\
\hline PBS & Phosphatpuffer \\
\hline PCR & Polymerase-Kettenreaktion \\
\hline $\mathrm{p}$ & piko \\
\hline RIA & Radioimmunoassay \\
\hline RNA & Ribonukleinsäure \\
\hline RNAse & Ribonuklease \\
\hline RNAsin & Ribonuklease-Hemmer \\
\hline RT & Raumtemperatur \\
\hline RT & Reverse Transkriptase \\
\hline $\mathrm{Pt}$ & Platin \\
\hline S & sense \\
\hline SDS & Natriumdodecylsulfat \\
\hline sek. & Sekunde \\
\hline SOM & Somatostatin \\
\hline $\mathrm{T}$ & Thymidin \\
\hline TA & Totalaktivität \\
\hline Tab. & Tabelle \\
\hline TAMRA & Quencher-Farbstoff \\
\hline TBS & Trispuffer \\
\hline $\mathrm{T}_{\mathrm{m}}$ & Schmelztemperatur \\
\hline TNF- $\alpha$ & Tumor-Necrosis-Faktor alpha \\
\hline TSH & Thyreoidea-Stimulierendes-Hormon \\
\hline TUF & target unmasking fluid \\
\hline U & Uracil \\
\hline
\end{tabular}




$\begin{array}{ll}\text { ULS }^{\circledR} & \text { Universal Link System ULYSIS } \\ \text { Velc. } & \text { Velcorin } \\ \text { x } & \text { mal/fach } \\ \text { x g } & \text { Erdbeschleunigung } \\ \text { x-Gal } & \text { 5-Bromo-5-Chloro-3indol-ß-D-Galaktosid } \\ \mu & \text { mikro } \\ \text { z.B. } & \text { zum Beispiel } \\ \text { z.T. } & \text { zum Teil }\end{array}$




\section{Inhaltsverzeichnis}

1. Einleitung 1

$\begin{array}{lll}1.1 & \text { Cytokine } & 1\end{array}$

$\begin{array}{lll}1.2 & \text { IL-1 System } & 4\end{array}$

1.3 Zielsetzung der Studie 9

2. Material und Methoden 11

$\begin{array}{lll}2.1 & \text { Versuchstiere } & 11\end{array}$

2.2 Methoden zur quantitativen Bestimmung von Hormon- und

Cytokinspiegeln im Serum von Callithrix jacchus 12

$\begin{array}{lll}2.2 .1 & \text { Radioimmunoassay } & 13\end{array}$

$\begin{array}{lll}\text { 2.2.1.1 Testosteron-Assay } & 13\end{array}$

$\begin{array}{lll}\text { 2.2.1.2 Cortisol-Assay } & 14\end{array}$

2.2.2 Immunradiometrischer Assay 15

2.2.2.1 Active ${ }^{\mathrm{TM}}$ Prolaktin-Assay 15

2.2.3 Enzyme-Linked-Immunosorbent-Assay (ELISA) 16

$\begin{array}{lll}\text { 2.2.3.1 Interleukin-6 Assay } & 17\end{array}$

2.23.2 Interleukin-1 beta Assay 18

$\begin{array}{lll}\text { 2.2.3.3 TNF-alpha Assay } & 18\end{array}$

2.2.4 Auswertung der Assay-Messungen 19

$2.3 \quad$ Präparation der Gehirne 20

2.4 Herstellung der Paraffin- und Gefrierschnitte 21

2.4.1 Herstellung der Paraffinschnitte 21

2.4.2 Herstellung der Gefrierschnitte 22

$2.5 \quad$ Histologische Untersuchungen 22

2.5.1 Hämatoxilin-Eosin-Übersichtsfärbungen 23

2.5.1.1 Prinzip des TechMate ${ }^{\mathrm{TM}}$ Horizon 23

2.5.2 Molekularbiologische Verfahren 24

2.5.2.1 RNA-Gewinnung 24

2.5.2.2. Reverse Transkriptase (RT) 25

2.5.2.3 Sequenzsuche und Sequenzabgleich 26

2.5.2.3.1. Sonden und Primer für die in-situ-Hybridisierung 26 
2.5.2.4 Polymerase-Kettenreaktion (PCR) 28

2.5.2.5 On-shot-Transformation 30

2.5.2.6 Klonkultur 32

2.5.2.7 Gewinnung von Vektor DNA durch MidiPrep 32

2.5.2.8 Sequenzierung 33

2.5.2.9 Linearisierung der dsDNA mit dem RiboMax-Kit 33

2.5.2.10 Prinzip der in-situ-Hybridisierung mit 34

2.5.2.10.1 Dig-Markierung der RNA 36

2.5.2.10.2 Dig-in-situ-Hybridisierung (ISH) 37

2.5.2.10.3 Biotin-Markierung der RNA 39

2.5.2.10.4 Biotin-in-situ-Hybridisierung mit GenPoint 40

2.5.2.10.5 Nachweis der Sondenspezifität durch Northern Blots 43

2.5.3 Immunhistologische Nachweismethoden (IHC) 45

2.5.3.1 Antikörper 46

2.5.3.2 DAKO EnVision ${ }^{\mathrm{TM}_{+}}$und DAKO ChemMate ${ }^{\mathrm{TM}}$ EnVision+ 47

2.5.3.2.1 DAKO EnVision ${ }^{\mathrm{TM}_{+}} 48$

2.5.3.2.2 DAKO ChemMate ${ }^{\mathrm{TM}}$ EnVision+ 49

2.5.3.3 Doppelfärbungen (ISH/IHC) 49

2.5.4 Auswertung der Färbungen 50

2.6 RT-PCR (TaqMan-PCR) 50

2.6.1 Sonden und Primer für die TaqMan-PCR 51

2.6.2 Hirnstanzen 52

2.6.3 RNA-Aufarbeitung 55

2.6.3.1 RiboGreen 55

2.6.4 Reverse Transkriptase 56

2.6.5 Durchführung des TaqMan Assays 56

$\begin{array}{lll}\text { 2.6.6 Auswertung des TaqMan Assays } & 57\end{array}$

3. $\quad$ Ergebnisse $\quad 58$

3.1 Quantitative Bestimmung von Hormon- und Cytokinspiegeln 58 im Serum

$\begin{array}{lll}3.1 .1 & \text { Testosteron-Assay } & 59\end{array}$ 
$\begin{array}{lll}3.1 .2 & \text { Cortisol-Assay }\end{array}$

$\begin{array}{lll}3.1 .3 & \text { Prolaktin-Assay } & 61\end{array}$

$\begin{array}{lll}3.1 .4 & \text { IL-6-Assay } & 61\end{array}$

3.1.5. IL-1ß-Assay 62

3.1.6. TNF- $\alpha$-Assay 63

$\begin{array}{lll}3.2 & \text { Histologie } & 64\end{array}$

3.2.1 Hämatoxilin-Eosin-Übersichtsfärbungen 64

3.2.2 In-situ-Hybridisierungs-Sondensequenzen 65

3.2.2.1 Sequenzhomologien 66

3.2.2.1.1 Interleukin-1 beta 66

3.2.2.1.2 Interleukin-1 Rezeptor Antagonist 67

3.2.2.1.3 Interleukin-1 Rezeptor Typ I 68

3.2.2.1.4 Interleukin-1 Rezeptor Typ II 69

3.2.3 In-situ-Hybridisierungs Nachweismethoden 70

3.2.4 Immunhistologische Nachweismethoden 70

3.2.5 Nachweis der Expression von IL-1 $\beta$, IL-1ra, IL-1RI und 71

3.2.5.1 Interleukin-1 beta (IL-1 $\beta$ ) 72

3.2.5.2 Interleukin-1 Rezeptor Antagonist (IL-1ra) 75

3.2.5.3 Interleukin-1 Rezeptor Typ I (IL-1RI) 78

3.2.5.4 Interleukin-1 Rezeptor Typ II (IL-1RII) 81

3.2.6 Glia oder Neuron? 84

3.2.7 Verteilung der positiven Signale der ISH

$\begin{array}{lll}3.3 & \text { RT-PCR } & \mathbf{8 8}\end{array}$

3.3.1 IL-1 $\beta$ und IL-1ra mRNA Expression im Claustrum 89

3.3.2 IL-1 $\beta$ und IL-1ra mRNA Expression im Cortex 90

3.3.3 IL-1 $\beta$ und IL-1ra mRNA Expression im Hippocampus 91

3.3.4 IL-1 $\beta$ mRNA Expression der Kontrollgruppe 92

3.3.5 IL-1ra mRNA Expression der Kontrollgruppe 93

$\begin{array}{lll}4 . & \text { Diskussion } & 94\end{array}$

4.1 Cytokin- und Hormonspiegel 94

4.1.1 Die Cytokine IL-1 $\beta$ und TNF- $\alpha \quad 94$

4.1.2 Das Streßhormon Cortisol 96 
4.1.3 Das Streßhormon Prolaktin 97

4.1.4 Das Hormon Testosteron 98

$\begin{array}{lll}4.2 & \mathbf{1 0 0}\end{array}$

$\begin{array}{lll}\text { 4.2.1 Die Sequenzen des IL-1 Systems } & 100\end{array}$

4.2.2 Histologische Verteilung und Bedeutung der 102 einzelnen IL-1 Systemkomponenten

4.2.2.1 Der Agonist Interleukin-1 beta 102

4.2.2.2 Der Interleukin-1 Rezeptor Antagonist 104

4.2.2.3 Die beiden Interleukin-1 Rezeptoren Typ I und Typ II 105

4.3 Der quantitative Nachweis des Agonisten IL-1 $\beta$ und des $\quad 107$ Antagonisten IL-1ra

$\begin{array}{lll}\text { 5. Zusammenfassung } & 110\end{array}$

$\begin{array}{lll}\text { 6. Literaturverzeichnis } & 111\end{array}$

7. Anhang 123

$\begin{array}{lll}7.1 & \text { Geräte und Verbrauchsmaterialien } & 123\end{array}$

$\begin{array}{lll}7.2 & \text { Verwendete Kits } & 124\end{array}$

$\begin{array}{lll}7.3 & \text { Chemikalien und Reagenzien } & 125\end{array}$

7.4 Maschinenprotokolle 131

7.4.1 HE-Färbungen mit dem Dako TechMate ${ }^{\mathrm{TM}}$ Horizon $500 \quad 131$

7.4.2 EnVision ${ }^{\mathrm{TM}}$-Färbungen mit dem Dako TechMate ${ }^{\mathrm{TM}}$ Horizon $500 \quad 132$ 


\section{Einleitung}

\subsection{Cytokine}

Innerhalb der letzten zehn Jahre hat das Interesse an der Funktion und Wirkung von Cytokinen stark zugenommen. Cytokine sind eine Gruppe von multifunktionellen Polypeptiden, die in einer Vielzahl unterschiedlichster Zelltypen (Makrophagen, Lymphocyten, Granulozyten, Neuronen, Gliazellen u.a.) produziert werden. Sie dienen als Mediatoren zwischen den Zellen und regulieren u.a. Proliferation, Differenzierung und Funktionen der Zellen. Mit den Cytokinen wird klassisch die Aktivierung des Immunsystems und die Immunantwort assoziiert. Sie sind nicht nur an der Immunabwehr beteiligt, sondern auch an einer Vielzahl physiologischer und pathophysiologischer Prozesse im peripheren Nervensystem (PNS) und im zentralen Nervensystem (ZNS).

$\mathrm{Zu}$ den Cytokinen gehören verschiedene Unterfamilien. Die wichtigsten Familien sind die Interleukine (z.B. IL-1, IL-6 u.v.a.), die Chemokine (z.B. Macrophagen inflammatory Protein, MIP- $\alpha$ und MIP- $\beta$ ), die TNF-Familie (z.B. TNF- $\alpha$ und TNF- $\beta$ ) und die Interferone (IFN $\alpha, \beta$ und $\chi$ ). Weiter gehören die Colony stimulierenden Faktoren (CSF), Wachstumsfaktoren und Neutrophine zu den Cytokinen.

Die Gruppe der Cytokine werden nach der Wirkungsweise eingeteilt. Dabei werden anti-inflammatorische von pro-inflammatorischen Cytokinen unterschieden. Die proinflammatorischen Cytokine wie z.B. IL-1, IL-6, IL-8 und Tumor Necrosis Factor (TNF $\alpha$ ) wirken stimulierend (aktivieren u.a. die T-Helferzellen Typ 1, daher auch Th1 genannt), die anti-inflammatorischen (Th2) wie z.B. IL-4, IL-10 und Insulin-likeGrowth-Factor-1 (IGF-1) hemmend. Zwischen diesen beiden Gruppen besteht eine empfindliche Balance (Szelenyi 2001). Wird die Expression und somit die Aktivität der Cytokine schnell erhöht, löst dies ein komplexes Kaskadensystem aus, d.h. nach Verschiebung des Gleichgewichtes in eine Richtung, aktivieren sich die Cytokine durch ihre eigene Anwesenheit selbst weiter, aber sie können auch andere Cytokine aktivieren. Cytokine können entweder indirekt oder direkt auf das ZNS wirken. Indirekt wirken die Cytokine auf Zellen des peripheren Nervensystems. Dort ist das Immunsystem eng mit dem Nervensystem bidirektional verknüpft. Einerseits über Cytokinrezeptoren auf den Zellen des Nervensystems und andererseits über neuronale Rezeptoren für 
Neurotransmitter/-peptide auf Immunzellen. Die Verknüpfung des peripheren Nervensystems, welches u.a. über den peripheren Vagusnerv zum Gehirn verschaltet ist, wurde durch Vagotomie-Experimente untersucht. Dafür wurde der Vagusnerv von Ratten durchtrennt, dies hob die induzierte (Lipopolysaccharid, LPS) Schmerzempfindlichkeit der Ratten auf (Bluthe et al. 1994).

Direkt wirken die Cytokine im Gehirn selbst. Zwei mögliche Ursprünge der Cytokine kommen in Frage: entweder gelangen zirkulierende periphere Cytokine über die BlutHirn-Schranke (BBB) in das Gehirn, oder im Gehirn selbst werden Cytokine produziert. Das Cytokine über die Blut-Hirn-Schranke gelangen zeigte ein Versuch von Banks et al. (1991). Radioaktiv markiertes humanes IL-1 $\alpha$, Maus IL-1 $\beta$ und Maus-IL-1 $\alpha$ wurden i.v. Ratten verabreicht. Alle drei Cytokine ließen sich in den Gehirnen der Ratten nachweisen. Ebenfalls Anfang der 90er Jahre erbrachten Neurobiologen den Nachweis für die Existenz von Cytokinen (Laye et al. 1994) und deren Rezeptoren (Cunningham \& DeSouza 1993, Wong \& Licinio 1994, Yabuuchi et al. 1994b) nach Induzierung im Gehirn u.a. von Ratten und Mäusen mittels radioaktiver In-situ-Hybridisierung (ISH), Immunhistochemie (IHC) und RT-PCR.

So konnten mit Hilfe von ISH, IHC und Zellkulturen in weiteren zahlreichen Studien einige Cytokine, vorwiegend Interleukine, und deren Rezeptoren den verschiedenen Zelltypen, wie Neuronen und Gliazellen (Astrozyten, Oligodendrozyten und Mikroglia), im Gehirn von u.a. Menschen, Ratten, Mäusen und Kaninchen zugeordnet werden (Tabelle 1). 
Tab.1: Cytokine und ihre Rezeptoren, die im Gehirn identifiziert wurden (modifiziert nach Sternberg 1997 und Szelenyi 2001): C: Cytokin, R: Rezeptor

\begin{tabular}{|c|c|c|c|c|c|}
\hline \multicolumn{2}{|c|}{ Cytokine } & \multicolumn{4}{|c|}{ Zelltypen } \\
\hline Name & Тур & Neuron & Astrozyten & Oligodendrozyten & Mikroglia \\
\hline IL-1 & Th1 & $\mathrm{C} / \mathrm{R}$ & $\mathrm{C} / \mathrm{R}$ & $\mathrm{C} / \mathrm{R}$ & $\mathrm{C}$ \\
\hline IL-2 & Th1 & $\mathrm{C} / \mathrm{R}$ & & $\mathrm{R}$ & $\mathrm{R}$ \\
\hline IL-3 & Th1 $\approx$ Th2 & $\mathrm{C} / \mathrm{R}$ & $\mathrm{C} / \mathrm{R}$ & $\mathrm{R}$ & $\mathrm{R}$ \\
\hline IL-4 & Th2 & & $\mathrm{R}$ & $\mathrm{R}$ & $\mathrm{R}$ \\
\hline IL-5 & Th2 & $\mathrm{C} / \mathrm{R}$ & $\mathrm{C} / \mathrm{R}$ & & $\mathrm{C} / \mathrm{R}$ \\
\hline IL-6 & $\operatorname{Th} 1 \approx \operatorname{Th} 2$ & $\mathrm{C} / \mathrm{R}$ & $\mathrm{C} / \mathrm{R}$ & & $\mathrm{C} / \mathrm{R}$ \\
\hline IL-7 & & & $\mathrm{R}$ & $\mathrm{R}$ & $\mathrm{R}$ \\
\hline IL-8 & & $\mathrm{R}$ & $\mathrm{C} / \mathrm{R}$ & & $\mathrm{R}$ \\
\hline IL-9 & Th2 & & $\mathrm{R}$ & & \\
\hline IL-10 & Th2 & $\mathrm{C} / \mathrm{R}$ & & & $\mathrm{C} / \mathrm{R}$ \\
\hline IL-11 & & & $\mathrm{C}$ & & \\
\hline IL-12 & Th1 & & & & $\mathrm{C}$ \\
\hline IL-13 & Th2 & & & & \\
\hline IL-14 & Th2 & & & & \\
\hline IL-15 & & $\mathrm{C}$ & & & $\mathrm{C}$ \\
\hline \multicolumn{6}{|l|}{ IL-16 } \\
\hline \multicolumn{6}{|l|}{ IL-17 } \\
\hline IL-18 & Th1 & & & & \\
\hline TNF- $\alpha$ & Th1 & $\mathrm{R}$ & $\mathrm{C} / \mathrm{R}$ & $\mathrm{R}$ & $\mathrm{C} / \mathrm{R}$ \\
\hline $\mathrm{INF}-\gamma$ & Th1 & & $\mathrm{C} / \mathrm{R}$ & & $\mathrm{R}$ \\
\hline TGF- $\beta$ & Th2 & & $\mathrm{C} / \mathrm{R}$ & $\mathrm{C} / \mathrm{R}$ & $\mathrm{C} / \mathrm{R}$ \\
\hline GM-CSF & & $\mathrm{R}$ & $\mathrm{C} / \mathrm{R}$ & $\mathrm{R}$ & $\mathrm{R}$ \\
\hline $\mathrm{M}-\mathrm{CSF}$ & & & $\mathrm{C}$ & $\mathrm{R}$ & $\mathrm{C} / \mathrm{R}$ \\
\hline
\end{tabular}

Um die Effekte und Verschaltungen der Cytokine näher untersuchen zu können, ist es notwendig eine künstlich (kontrollierte) Cytokinreaktion hervorzurufen.

Externer Streß (z.B. Trauma) oder interner Streß (z.B. Angstzustände, Erkrankungen) verursacht eine Immunantwort und induziert die proinflammatorischen Cytokine. Um einen künstlich ausgelösten Effekt zu erzielen, gibt es verschiedene Möglichkeiten (UVBestrahlung, Gabe von proinflammatorischen Cytokinen und LPS) dies auszulösen (Nashan \& Luger 1999a,b). Die am häufigsten verwendete Methode ist die Erhöhung der Expression der Cytokine durch Gabe von LPS (Arend \& Massoni 1986, Betancur et al. 1995, DeLuigi et al. 1998, Doherty et al. 1992, Rivier et al. 1989 u.v.a.). LPS, ein Bestandteil der Gram-negativen Bakterienwand, verursacht denselben Effekt wie eine 
Gram-negative Bakterieninfektion. LPS induziert die Synthese und die Freisetzung der meisten inflammatorischen Cytokine, aktiviert u.a. B-Lymphozyten, Monozyten und Makrophagen. Besonders stark stimuliert LPS die Cytokine TNF- $\alpha$, IL-1 und IL-6.

\section{$1.2 \quad$ IL-1 System}

Bei dem in der vorliegenden Arbeit untersuchten System handelt es sich um das Interleukin-1 System, welches das wichtigste inflammatorische Cytokinsystem darstellt. Ursprünglich wurde es als Kostimulus für T-Zellen entdeckt (Gray et al. 1972).

$\mathrm{Zu}$ diesem System gehören drei Glycoprotein-Liganden: die Agonisten IL-1 $\alpha$ und IL-1 $\beta$ sowie der natürlich auftretende IL-1 Rezeptor Antagonist (IL-1 ra).

IL-1 $\alpha$ und IL-1 $\beta$ werden als $31 \mathrm{kD}$ Vorläuferproteine (pro-IL-1 $\alpha$ und pro-IL-1 $\beta$ ) synthetisiert (Dinarello 1996). Die Spaltung in das eigentliche Protein erfolgt durch spezifische Proteasen. Während pro-IL-1 $\alpha$ biologisch aktiv sein kann und im Cytosol der Zellen verbleibt, ist pro-IL-1 $\beta$ erst nach der proteolytischen Spaltung durch ICE (Interleukin-1 $\beta$ converting Enzym) aktiv (Cerretti et al. 1992). IL-1ra wird als $22 \mathrm{kD}$ Protein synthetisiert (Hannum et al. 1990).

Nach Sims \& Dower (1994) vervollständigen zwei Typen von Rezeptoren das System, der IL-1RI (80 kD) und der IL-1RII (69 kD). Sie sind in der Lage an ihrer extrazellulären Domäne die Agonisten IL-1 $\alpha$ und IL-1 $\beta$ sowie den Antagonisten zu binden. IL-1 $\alpha$ und IL-1 $\beta$ binden mit annähernd der selben Affinität an den IL-1RI. Das IL-1 und der IL-1RI bilden einen Komplex, der die Signalproteine auslöst (Hannum et al. 1990). Der IL-1ra bindet mit höherer Affinität als IL-1 $\alpha$ und IL-1 $\beta$ an den IL-1RI, löst jedoch kein Signal aus (Evans et al. 1995). Dies ist auf eine Besonderheit der beiden Agonisten zurückzuführen, die zwei Bindungsstellen haben, dem Antagonist fehlt dagegen eine (Schreuder et al. 1997). Mit der zusätzlichen Bindungsstellen kann der Agonist-Rezeptor-Komplex mit dem Interleukin-1 Rezeptor assoziiertes Protein (IL-1RAcP), welches zur Signalauslösung notwendig ist, binden, was für den Antagonisten-Rezeptor-Komplex nicht möglich ist (Abb. 1). Ohne das IL-1RAcP ist ein Signal über die Bindung an den IL-1RI nur schwach ausgeprägt, oder gar nicht nachweisbar (Dinarello 1997a-c). Der IL-1RII bindet bevorzugt IL-1 $\beta$. Nach Colotta et al. (1993) handelt es sich bei dem IL-1RII um einen sogenannten decoy-Rezeptor. Als 
decoy-Rezeptor wird ein Rezeptor bezeichnet, der zwar mit einer hohen Affinität den Liganden bindet, aber keine Signal weiter gibt (Mantovani 2001, Colotta et al. 1994). Die zur Signalübertragung notwendige intrazelluläre Domäne ist beim IL-1RII nur rudimentär (29 Aminosäuren) vorhanden. Sims et al. (1993) wiesen in ihrer Studie nach, daß IL-1 Signale nur über den IL-1RI vermittelt werden. Dazu wurden eine Mauszelllinie mit Maus IL-1 $\alpha$ stimuliert, da dieser Ligand gleichermaßen an den Maus IL-1RI und Maus IL-1RII bindet. Dies ist im humanen System nicht der Fall und der gleiche Versuch wurde mit einer humanen Zelllinie und humanen IL-1 $\beta$ durchgeführt. Zur Feststellung, welcher Rezeptor das Signal weiterleitete, wurde jeweils eine Blockierung mit einem Antikörper (IL-1 kann nicht an IL-1RI bzw. IL-1RII binden) vorgenommen.

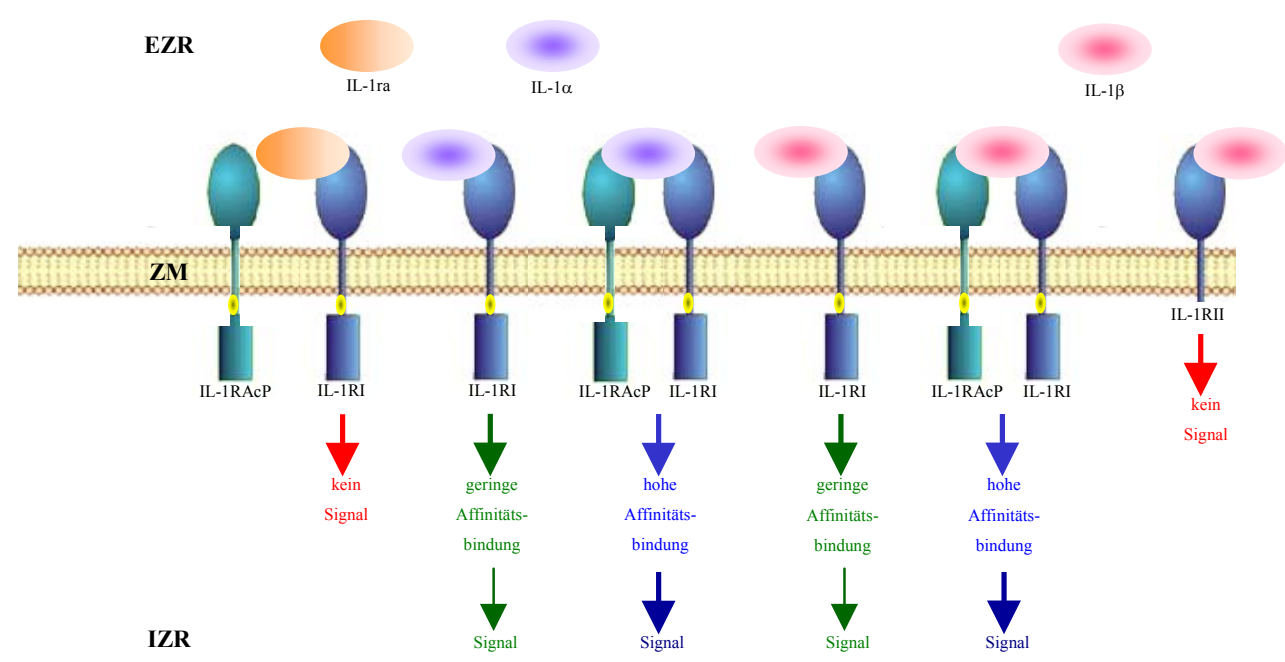

Abb.1: Möglichkeiten der Liganden-Rezeptorbindungen und Auslösung der Signale

EZR: Extrazellulärraum, IZR: Intrazellulärraum, IL-1 $\alpha$ und IL-1 $\beta$ : Interleukin-AgonistLiganden $\alpha$ und $\beta$, IL-1ra: Interleukin Rezeptor-Antagonist, IL-1RAcP: Interleukin Rezeptor assoziiertes Protein, ZM: Zellmembran

IL-1 $\alpha$ und IL-1 $\beta$ zeigen, soweit bekannt die selbe biologische Aktivität (Slack et al. 1993). Die klassisch mit IL-1 assoziierte Funktion ist die Immunabwehr und Entzündungsantwort (Dinarello 1996). IL-1 wird von Makrophagen, Endothelzellen, Kreatinozyten, neutrophilen Zellen, B-Lymphozyten, Fibroblasten, Epithel- und Dendriten-Zellen synthetisiert. Der Rezeptor I wird bevorzugt von T-Zellen und Zellen mesodermalen Ursprungs (Fibroblasten, Endothelzellen u.a.) synthetisiert, während der Rezeptor II hauptsächlich von B-Zellen und Makrophagen, Granulozyten und Monozyten exprimiert wird. Die Anzahl der Rezeptoren/Zelle schwankt für IL-1RI zwischen 25-1000 und für IL-1RII zwischen 200-8000. Die meisten Zellen exprimieren 
die Rezeptoren in geringer Dichte. Eine höhere Dichte zeigt sich nach einer Stimulation der Zellen mit IL-1 (Sedlacek \& Möröy 1995).

In Abwesenheit eines pathologischen Effekts ist das Grundniveau von IL-1 $\beta$ im gesunden Nagerhirn nur schwer nachweisbar. Vitkovic et al. (2000) beschreiben eine geringe, aber nachweisbare Expression aller Mitglieder der IL-1-Familie im Gehirn von gesunden Kaninchen. Durch die Blockierung von IL-1 oder TNF- $\alpha$ wurde eine Veränderung des Schlafverhaltens (Änderung in der slow-wave-Phase) ausgelöst. Dies macht die Bedeutung der Expression von IL-1 oder TNF- $\alpha$ und im gesunden Gehirn deutlich. Ähnliches zeigten Versuche über für den Einfluß einer intravenösen Gabe von IL-1 $\beta$ z.B. auf den Schlaf bei Ratten (längerer slow-wave-Schlaf, Krueger et al. 1994) und Kaninchen (Opp et al. 1994). Die Gabe von LPS verursacht einen Anstieg der IL$1 \beta$ Konzentration und ging mit eine Änderung im Freßverhalten (Reduzierung der Futteraufnahme) bei Ratten einher (Plata-Salaman 1998).

In Versuchen mit peripherer Gabe von LPS erhöhen sich die Niveaus der mRNA von IL-1 und TNF- $\alpha$ in den verschiedenen Hirnregionen (Breder et al. 1993, Wong et al., 1993). Hauptsächlich wird bei einer Reizung (Streß, Infekte) IL-1 $\beta$ in der Mikroglia exprimiert, aber auch in Astro-, Oligodendrozyten und andere Zellen. Astrozyten können Cytokine und Neuropeptide und deren Rezeptoren exprimieren. Diese Zellen üben einen Einfluß auf Neuronen, aber auch auf die Mikroglia aus.

Die Expression von IL-1 $\beta$ im ZNS wurde im Hypothalamus und Hippocampus von Nagern (Maus und Ratte) näher betrachtet (Ban et al. 1993, Farrar et al. 1987, Cunningham et al. 1992a,b). Parnet et al. (1994) lokalisierten IL-1 $\beta$ mRNA im Hippocampus der Maus. Lechan et al. (1990) wiesen IL-1 $\beta$ in der Ratte in Zellen der Gyrus dentata (=Fascia dentata) des Hippocampus und des Hypothalamus nach. IL-1 $\beta$ wurde in Neuronen (Lechan et al. 1990), Astrozyten (Pearson et al. 1999) und Mikrozyten (Sheng et al. 1998) nachgewiesen. Im Gehirn von Ratten wurde der IL-1RI in Neuronen u.a. im cerebralen Cortex nachgewiesen (Yabuuchi et al. 1994). Bei Mäusen wurde der IL-1RI in der Gyrus dentata des Hippocampus lokalisiert (Cunningham et al. 1992). Der IL-1RII wurde ebenfalls im Hippocampus vorgefunden. Zur Klärung der möglichen Verschaltung der einzelnen Liganden und Rezeptoren des IL-1-Systems ist neben der Lokalisation eine komplexe physiologische Untersuchung nötig. In einem Versuch mit Ratten zeigte sich, lokal in der Peripherie induziertes IL-1 $\beta$ bzw. TNF- $\alpha$ induzieren ihrerseits IL- 6 und verursachen so direkt und indirekt eine 
Immunantwort in Form von Fieber (Luheshi et al. 1997). Die Thermoregulation steht unter der direkten Kontrolle des ZNS, spezifisch der Hypothalamusregion. IL-1 $\beta$ kann u.a. mit dem ZNS über die Hypothalalmus-Hypophysen-Achse (HPA-Achse) interagieren (Abb.2 linke Seite).

Peripher und im Gehirn exprimierte Cytokine beeinflussen über die HPA-Achse die Freisetzung von Corticotropin-releasing Hormone (CRH) im Hypothalamus und in der Hypophyse die Freisetzung von Adrenocorticotropin Hormon (ACTH). CRH stimuliert die Freisetzung von ACTH. ACTH unterdrückt u.a. die Histokompatilitätskomplexe Klasse II Expression der Makrophagen und stimuliert die natürliche Killerzellen (NK) Aktivität (Johnson et al. 1992) und das in der Hypophyse gebildete ACTH beeinflußt die Nebenniere Glucocorticoide freizusetzen, die ihrerseits auf Entzündungen reagieren (Dunn 1992, Straub et al. 1998). Das wichtigste Glucocorticoid ist beim Menschen das entzündungshemmend wirkende Cortisol.

Die HPA-Achsen-abhängige Regulation des Immunsystems ist ein negativer Rückkopplungseffekt zwischen dem ZNS und dem Immunsystem (Dantzer 1994a,b, Dantzer et al. 1993).

Erhöhte Cytokinproduktion durch Makrophagen und Lymphocyten ist die ersten Immunaktivität der akute Phasen Antwort und erreicht über den Körperkreislauf auch entfernte endokrine Organe. Aktivierte Lymphozyten können eine geringe Menge an neuroendokrinen Hormonen, wie CRF, ACTH, SOM, TSH, GH, GHRH, Prolaktin und $\beta$-Endorphin bilden, die wiederum das Gehirn oder das periphere Nervensystem beeinflussen.

Von den Hormonen der Hypophyse (Abb.2 rechte Seite) ist bekannt, daß sie in der Lage sind Immunreaktionen zu modulieren. Dies wurde durch Studien zur Bedeutung der Streßeffekte auf Immunfunktionen an hypophysensektomierte Spraque-Dawely-Ratten von Keller et al. (1988) belegt. Die Hypophyse der Ratten wurde entfernt und dadurch war keine Reaktion des Immunsystems auf eine periphere Stimulanz zu beobachten. Durch die Zugabe von Prolaktin oder GH konnte dieser ausbleibende Effekt aufgehoben werden.

GH und Prolaktin haben besonders starke Effekte auf das Immunsystem (Johnson et al. 1997). Der Einfluß von GH auf die Immunoregulation wurde für mehrere Immunfunktionen nachgewiesen. GH übt z.B. einen Einfluß auf die T-Zellen- und NKZellen-Aktivität aus und stimuliert die Produktion von IL-1, IL-2 und TNF- $\alpha$. Studien an Mäusen zeigten eine dopaminerge Unterdrückung der Prolaktinsekretion und eine 
verspätete Immunantwort (Bernton et al. 1992). Dies läßt sich auch mit anderen Glucocorticosteroide erreichen. Eine starke Wirkung von solchen, als Medikamenten angewendeter Stoffe, auf das Immunsystem liegt auch im Menschen nahe.

In Experimenten an ovariectomierten Rhesusaffen zeigten Feng et al. (1991), daß eine intracerebroventriculäre Gabe von IL-1 einen starken Anstieg der Cortisolsekretion, neben einer verminderten LH Sekretion verursacht.

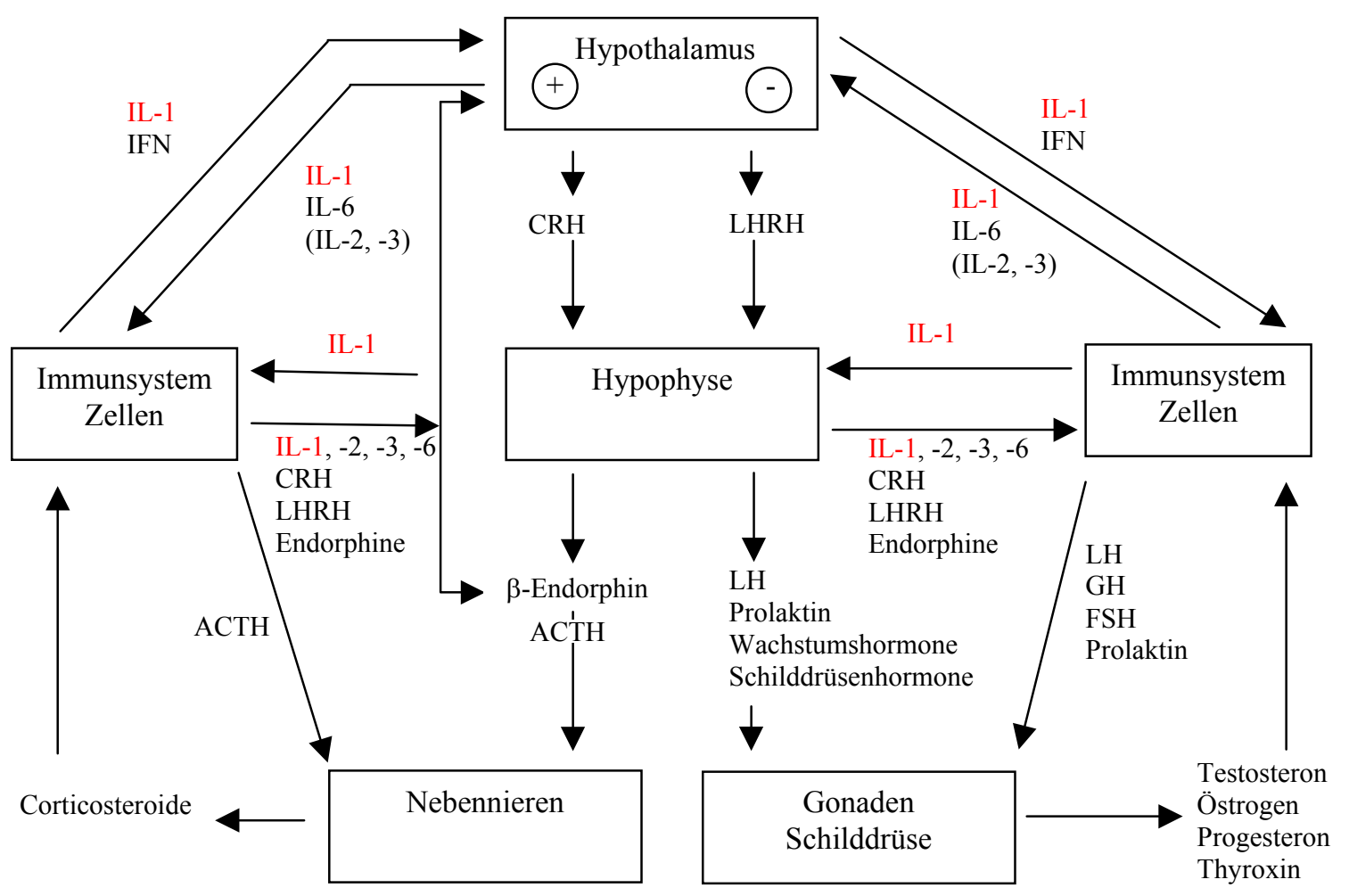

Abb.2: Kommunikationswege des ZNS mit dem Immunsystem (modifiziert nach Sedlacek \& Möröy 1995): ACTH: Corticotropin, CRH: Corticotropin-Releasing Hormone, FSH: Folikel stimulierendes Hormon, GH: Wachstumshormon, IL-1: Interleukin-1, IL-2: Interleukin-2, IL-3: Interleukin-3, IL-6: Interleukin-6, IFN: Interferon LH: luteinisierendes Hormon, LHRH: Luteinisierendes Realising Hormon

In den letzten Jahren haben Untersuchungen über den Zusammenhang von Schädigungen des Gehirns und dem programierten Zelltod (Apoptosis) bei z.B. der Alzheimer-Erkrankung und Multipler Sklerose (Merrill 1992, Merrill et al. 1991a\&b) und einer hohen IL-1 $\beta$-Expression stark zugenommen. In Zellkulturexperimenten über neurodegenerative Effekte von Gliazellen (Chao et al. 1995) verschlimmerten IL-1 $\beta$ und TNF- $\alpha$ den Neuronentod in den gemischten Neuron-Glia-Zellkulturen. 
Neurotoxischen und neuroschützenden Mechanismen sind eng mit den pro- und antiinflammatorischen Cytokinen verknüpft (Szenenyi 2001). Die vermehrte Expression von pro-inflammatorischen Cytokinen verursacht Veränderungen in den Neuronen, lange vor dem eigentlichen Zelltod.

IL-1 $\beta$ scheint an verschiedenen neurologischen Krankheiten, wie z.B. Parkinson oder Epilepsie beteiligt zu sein (Rothwell \& Luheshi 2000) und spielt eine große Rolle als Immunmodulatormolekül im zentralen Nervensystem (Haour et al. 1994, Rothwell \& Hopkins 1995).

Andererseits haben die anti-inflammatorischen Cytokine im ZNS zellprotektive Eigenschaften und wirken stabilisierend auf die Homeostasis während der Unterdrückung der Immunantwort (Feuerstein 1998, Rothwell 1999). Diese Eigenschaft wird für Therapieansätze bei chronischen Erkrankungen benutzt. Die Gabe von IL-1ra in der Krebstherapie unterstützt die Unterdrückung der nicht erwünschten Immunreaktionen.

\subsection{Zielsetzung der Studie}

Als mögliches neues Tiermodell zur Untersuchung der Regulation von Cytokinen wurde die Gattung der nichtmenschlichen Primaten Callithrix jacchus (C. jacchus) ausgewählt.

Ein Tiermodell weist verschiedene Vorzüge und Möglichkeiten auf, die bei der Untersuchung an Menschen nicht genutzt werden können. Es sind bei den Tieren experimentielle Manipulation möglich, die im Menschen aufgrund ethischer und praktischer Überlegungen so nicht durchführbar sind.

Die meisten der bisher durchgeführten Experimente und Studien zur Wirkung von Cytokinen im Gehirn sind mit Ratten und anderen Nagern durchgeführt worden (Farrar et al. 1987, Ban et al. 1991; Cunningham 1992; Parnet et al. 1994). Die Physiologie dieser Tiere unterscheidet sich von der des Menschen in einigen Punkten, z.B. haben Ratten und Menschen unterschiedliche lange Schlafzyklen. Es lassen sich nicht alle Ergebnisse ohne weiteres auf den Menschen übertragen. Nur wenige Studien wurden im Hinblick auf die Vernetzung des Immunsystems und des neuroendokrinen Netzwerk an anderen Säugetieren (Kaninchen, Schwein und Primaten) durchgeführt. Es gibt 
Untersuchungen an ovariectomierten Rhesusaffen bezüglich der Auswirkungen von Streß (Xiao et al. 1998, 1999, 2000).

Die in dieser Studie verwendeten Affen der Gattung C. jacchus sind ein besonders geeignetes Tiermodell, da die Wechselwirkungen des Nerven- mit dem Immunsystems und das Zusammenspiel mit dem endokrinen System morphologisch und physiologisch dem Menschen, z.B. in der Zykluslänge, ähneln. Es wurden bereits verschiedene Untersuchungen u.a. über die Entwicklung der Hypophysen-Nebennieren-Funktion (Pryce et al. 2002) in Jungtieren vorgenommen. Es liegt auch eine Studie zur Auswirkung einer IL-1 $\alpha$ Injektion auf die ACTH- und Cortisol-Sekretion vor (Bernardini et al. 2001). Zudem gilt der C. jacchus bereits als ein gutes Tiermodel zur Untersuchung für Immuntherapien bei Multipler Sklerose (McFarland et al.2001).

Die Tiere wurde im Rahmen der Durchführung der Arbeit im Graduiertenkolleg „Perspektiven der Primatologie“ durch das Deutsch Primatenzentrum zur Verfügung gestellt (DPZ).

In der vorliegenden Arbeit sollte nun zunächst der Einfluß der künstlichen Stressung mittels LPS und deren Auswirkung auf die Cytokine und den Hormonhaushalt (Änderung der HPA-Achse) in Untersuchungen am Blutserum mittels RIA- und ELISA-Assays vorgenommen und überprüft werden.

Um die möglichen Veränderungen auf histologischer Ebene darzustellen, sollte eine Möglichkeit zur Identifizierung (partielle Sequenzen) der einzelnen IL-1 $\beta$ Systemkomponenten im Gehirn von Callithrix jacchus entwickelt und mit Hilfe der Technik der in-situ Hybridisierung das Verteilungsmuster im Gehirn untersucht werden. Es wurde eine Identifizierung des Zelltyps oder der Zelltypen (Neuron oder Glia) mittels immunhistologischen Antikörpernachweisen angestrebt, welche die einzelnen Komponenten exprimieren. So sollten Ansätze zur Untersuchung der Regulationsmechanismen dieses Systems geschaffen werden.

Zusätzlich sollte ein System zur Quantifizierung und zum Nachweis der Expression der IL-1 $\beta$-Systemkomponenten mittels RT-PCR (TaqMan) entwickelt werden. 


\section{2 Material und Methoden}

In diesem Kapitel werden die einzelnen Prinzipien und die Durchführung der Methoden beschrieben. Benutzte Chemikalien, Materialien und Geräte werden mit ihren Bezugsquellen im Anhang aufgeführt.

\subsection{Versuchstiere}

Bei den Versuchstieren handelte es sich um Affen der Gattung Callithrix jacchus $(C$. jacchus, Abb.3). Die zur Ordnung der Neuweltaffen (Platyrrhini) gehörenden Tiere zeichnen sich durch einen geringen Sexualdimorphismus aus (Parker \& Martin 1990). Sie wurden über das Deutsche Primatenzentrum (DPZ) bezogen. Alle 14 Tiere waren männlichen Geschlechts und ca. 2 Jahre alt (Tab.2). Im Durchschnitt waren die Tiere zwischen 26 bis $31 \mathrm{~cm}$ groß (Länge Kopf bis Schwanzansatz) und wogen zwischen 278 bis $463 \mathrm{~g}$.

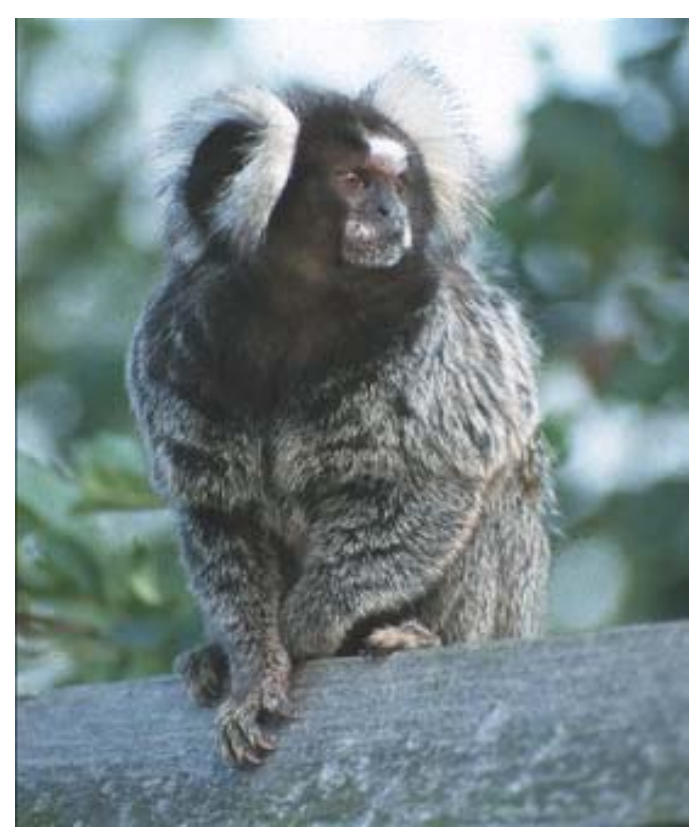
Abb.3: C. jacchus, Männchen Foto A.Thieß

Sieben Tiere wurden mit $1 \mathrm{ml}$ Lipopolysaccharid (LPS aus Escherichia coli) der Endkonzentration $40 \mu \mathrm{g} / \mathrm{ml}$ der Firma Sigma intramuskulär (i.m.) injiziert. LPS bewirkt 
eine Reaktion des Immunsystems, stellt also einen künstlich erzeugten Streßfaktor für die Tiere da und bewirkt einen Anstieg im Interleukin-Niveau. Zur Kontrolle wurden sieben Tiere mit $1 \mathrm{ml}$ isotonischer Natrium-Chlorid-Lösung ( $\mathrm{NaCl}$, Braun) i.m. gespritzt. Nach jeweils 3 Stunden wurden die Tiere mit einer Ketamin (animedica)/Braunol Narkose betäubt. Die Tiere sind mit Hilfe von Vacutainern (Vakuum-Blutentnahme-Spritzen der Firma BD) durch eine Herzpunktion ausgeblutet und dabei schließlich durch eine Überdosis Narkosemittel eingeschläfert worden. Unmittelbar danach wurden die Gehirne und Gewebeproben entnommen. Alle Tiere waren zum Versuchszeitpunkt gesund und pathologisch unauffällig.

Der Tierversuch wurde durch die Bezirksregierung Braunschweig genehmigt.

Tab.2: Daten der Versuchstiere

\begin{tabular}{c|c|c|c} 
Nummer & geboren & Gewicht & Behandlung \\
\hline $\mathbf{1}$ & 12.01 .2000 & $431 \mathrm{~g}$ & $\mathrm{LPS}$ \\
\hline $\mathbf{2}$ & 14.01 .2000 & $346 \mathrm{~g}$ & $\mathrm{LPS}$ \\
\hline $\mathbf{3}$ & 12.01 .2000 & $434 \mathrm{~g}$ & $\mathrm{NaCl}$ \\
\hline $\mathbf{4}$ & 12.01 .2000 & $445 \mathrm{~g}$ & $\mathrm{NaCl}$ \\
\hline $\mathbf{6}$ & 20.05 .2000 & $438 \mathrm{~g}$ & $\mathrm{LPS}$ \\
\hline $\mathbf{7}$ & 17.05 .2000 & $424 \mathrm{~g}$ & $\mathrm{LPS}$ \\
\hline $\mathbf{8}$ & 01.02 .2000 & $393 \mathrm{~g}$ & $\mathrm{LPS}$ \\
\hline $\mathbf{9}$ & 10.03 .2000 & $366 \mathrm{~g}$ & $\mathrm{NaCl}$ \\
\hline $\mathbf{1 0}$ & 02.10 .1999 & $278 \mathrm{~g}$ & $\mathrm{NaCl}$ \\
\hline $\mathbf{1 1}$ & 03.04 .2000 & $330 \mathrm{~g}$ & $\mathrm{LPS}$ \\
\hline $\mathbf{1 2}$ & 08.04 .2000 & $352 \mathrm{~g}$ & $\mathrm{LPS}$ \\
\hline $\mathbf{1 3}$ & 13.03 .2000 & $382 \mathrm{~g}$ & $\mathrm{NaCl}$ \\
\hline $\mathbf{1 4}$ & 08.04 .2000 & $357 \mathrm{~g}$ & $\mathrm{NaCl}$ \\
\hline & & &
\end{tabular}

\subsection{Methoden zur quantitativen Bestimmung von Hormon- und Cytokinspiegeln im Serum von Callithrix jacchus}

Um die Auswirkungen der LPS-Behandlung auf die Hormone und die Cytokinsekretion zu bestimmen, wurden Serumuntersuchungen für die Hormone Testosteron, Prolaktin 
und Cortisol vorgenommen. Von den Cytokinen wurden die IL-1 $\beta$-, IL-6- und TNF $\alpha$ Spiegel in verschiedenen Assays untersucht.

\subsection{1 $\quad$ Radioinmunoassay (RIA)}

Für einen RIA benötigt man spezifische, meist in Kaninchen erzeugte, Antiseren gegen die zu testende Substanz.

Der Radioimmunoassay zur quantitativen Bestimmung von Testosteron und Cortisol im Serum beruht auf dem Grundprinzip, daß radioaktive und nicht radioaktive Antigene um eine begrenzte Anzahl von Antikörperbindungsstellen konkurrieren.

Nach einer definierten Inkubationszeit werden die an den Antikörper gebundenen Komponenten durch eine Fällung mit einer Präzipitatlösung (Gemisch aus dem zweiten Antikörper und Polyethylenglykol) von den freien Komponenten getrennt. Nach Zentrifugieren und Dekantieren des Überstandes wird die Radioaktivität im Präzipitat am Gammacounter gemessen. Mit Hilfe einer Standardkurve kann die Konzentration der zu untersuchenden Stoffe Testosteron und Cortisol in der Probe bestimmt werden.

Die Menge von ${ }^{125}$-I markierten Testosteron bzw. ${ }^{125}$-I markierten Cortisol welches an die Antikörper gebunden ist, ist umgekehrt proportional zur Testosteron- bzw. Cortisolkonzentration im Serum. Die Trennung von freiem und gebundenem Antigen ist bei Verwendung eines doppelten Antikörpersystems leicht und schnell durchführbar.

\subsubsection{Testosteron-Assay}

Zur quantitativen Bestimmung der Testosteronkonzentration im Serum von C. jacchus wurde ein für humanes Serum konzipierter RIA-Kit (DSL-4100) der Firma DSL ${ }^{\circledR}$ verwendet.

Es wurden sowohl von den Standards, den unspezifischen Bindungen (NSB) und den Kontrollen, als auch von allen Proben Doppelbestimmungen durchgeführt.

Alle Reagenzien wurden zunächst auf Raumtemperatur gebracht und z.T. entsprechend den Angaben des Herstellers gelöst. 
$50 \mu 1$ vom aufgelösten Standard, Kontrollen und Proben wurden in die entsprechend gekennzeichneten Röhrchen auf den Boden pipettiert. $150 \mu 1$ des Nullstandards sind in die NSB-Röhrchen (Messung der nicht-spezifischen Bindungen) gegeben worden. In alle Röhrchen wurden $500 \mu 1^{125}$ I-Testosteron pipettiert. Die TA-Röhrchen (Messung der Totalaktivität) wurden bei Raumtemperatur aufgehoben und erst zur Messung im Gammacounter wieder zu den anderen Ansätzen gestellt.

$100 \mu 1$ Testosteron-Antiserum wurden dann in alle Röhrchen dazugegeben. Nach dem Mischen der Ansätze mit dem Vortex wurden alle Röhrchen für 60 Minuten im Wasserbad bei $37^{\circ} \mathrm{C}$ inkubiert.

Nach dieser Inkubationszeit und der Zugabe von $1000 \mu 1$ präzipitierender Reagenz wurden die Ansätze erneut gemischt und bei Raumtemperatur für 10 bis 15 Minuten inkubiert.

Alle Röhrchen sind bei 3000 g für 15 bis 20 Minuten zentrifugiert worden. Die Ansätze wurden dekantiert und anschließend für 1 Minute im Gammacounter gemessen. Die Ergebnisse wurden anhand der Standards in $\mathrm{ng} / \mathrm{ml}$ umgerechnet.

\subsubsection{Cortisol-Assay}

Zur quantitativen Bestimmung der Cortisolkonzentration im Serum von C. jacchus wurde ein für humanes Serum konzipiertes RIA-Kit (DSL-2000) der Firma DSL ${ }^{\circledR}$ verwendet.

Es wurden sowohl von den Standards und den Kontrollen, als auch von allen Proben Doppelbestimmungen durchgeführt.

Alle Reagenzien wurden zunächst auf Raumtemperatur gebracht und z.T. entsprechend den Angaben des Herstellers gelöst.

$25 \mu \mathrm{l}$ vom aufgelösten Standard, Kontrolle und Proben wurden in die entsprechend gekennzeichneten Röhrchen auf den Boden pipettiert.

$500 \mu 1{ }^{125}$ I-Cortisol wurden sofort zu allen Ansätzen gegeben. Die TA-Röhrchen wurden wieder bei Raumtemperatur inkubiert und erst zur Messung im Gammacounter zu den anderen Ansätzen gestellt.

In alle Röhrchen wurde $500 \mu$ l Cortisol-Antiserum-Komplex gegeben und durch vortexen gut gemischt. 
Nach einer Inkubation von 45 Minuten im Wasserbad bei $37{ }^{\circ} \mathrm{C}$ wurden die Röhrchen für 10 bis 15 Minuten bei $3000 \mathrm{~g}$ zentrifugiert.

Anschließend wurden die Ansätze dekantiert und danach für 1 Minute im Gammacounter gemessen worden. Die Standards dienten zur Umrechnung der Ergebnisse der Proben in ng/ml.

\subsubsection{Immunradiometrischer $\underline{\text { Assay }}$ (IRMA)}

Der immunradiometrische Assay zur quantitativen Bestimmung von Prolaktin im Serum basiert auf der von Addison und Miles et al. beschriebenen Methode.

An der Röhrchenwand immobilisierte monoklonale Prolaktin-Antikörper und ${ }^{125} \mathrm{I}$ markierten Antikörper bilden zusammen mit dem im Serum vorhandenen Prolaktin einen Sandwichkomplex. Nach einer Inkubation werden alle nicht an die Röhrchenwand gebundene Komponenten durch Waschen und Dekantieren entfernt. Danach wird die Radioaktivität der gebundenen Komponenten im Gammacounter gemessen.

\subsubsection{Active $^{\mathrm{TM}}$ Prolaktin-Assay}

Zur quantitativen Bestimmung der Prolaktinkonzentration im Serum von C. jacchus wurde ein für humanes Serum konzipiertres IRMA-Kit (DSL-4500) der Firma DSL ${ }^{\circledR}$ verwendet.

Es wurden sowohl von den Standards und den Kontrollen, als auch von allen Proben Doppelbestimmungen durchgeführt.

Alle Reagenzien wurden zunächst auf Raumtemperatur gebracht und z.T. entsprechend den Angaben des Herstellers verdünnt.

Die Röhrchen für die Standards, die Kontrollen und die Proben wurden mit im Kit geliefert. Für die Messung der Totalaktivität wurden unbeschichtete Röhrchen verwendet.

Je $25 \mu 1$ Standard, Kontrolle und Probe wurden in die entsprechenden Röhrchen auf den Boden pipettiert. 
Sofort sind dann $200 \mu 1{ }^{125}$ I-Anti-Prolaktin-Antikörper in alle Röhrchen gegeben worden. Durch Schütteln des Ständers wurden diese gemischt und anschließend auf einem Schüttler bei $10 \mathrm{~g} 90$ Minuten bei Raumtemperatur inkubiert.

Alle Röhrchen außer den TA-Röhrchen sind dekantiert worden.

Anschließend wurden die Röhrchen mit $2.5 \mathrm{ml}$ Waschpuffer gewaschen und dekantiert. Dieser Vorgang wurde insgesamt 3 mal wiederholt. Danach wurden alle Röhrchen für 1 Minute im Gammacounter gemessen. Die Ergebnisse dieser Messungen wurden mit Hilfe der Standards in $\mathrm{ng} / \mathrm{ml}$ umgerechnet.

\subsubsection{Enzyme-Linked-Immunosorbent- $\underline{\text { Assay }}$ (ELISA)}

Beim enzyme-linked immunosorbent assay (ELISA) finden im Prinzip die gleichen Schritte wie beim IRMA statt. Im Gegensatz $\mathrm{zu}$ den radioaktiv markierten Antikörpertests, die oben beschrieben wurden, wird bei dieser Methode der zweite Antikörper mit einem Enzym (z.B. horse-radish-peroxidase HRP oder Alkalischer Phosphatase) gekoppelt. Durch die katalytische Aktivität des Enzyms entsteht eine intensiv gefärbte oder fluoreszierende Verbindung. Weniger als ein Nanogramm eines Proteins können so nachgewiesen werden.

Dieser Assay wird auf einer Mikrotiterplatte durchgeführt, die basierend auf dem oligoklonalen System mit einer Mischung aus monoklonalen Antikörpern (MAk's) gegen verschiedene Epitope z.B. von IL-6, IL-1 $\beta$ oder TNF-alpha beschichtet ist.

Nach der Inkubation mit den zu untersuchenden Proben, wird der mit HRP-, AP- oder Biotin-markierte zweite Antikörper (2.MAk) zugegeben. Es bildet sich ein Komplex: z.B. gebundene MAk's - IL-6 -2.MAk-HRP. Nach dem Waschen (Entfernung der nicht gebundenen Komponenten) wird die Chromogen-Inkubation durchgeführt. Die Menge an Substratumsatz wird als Farbumschlag gemessen. Die Werte werden in Bezug zur Stadardkurve berechnet. 


\subsubsection{Interleukin-6 Assay}

Ein für humanes Serum konzipierter Immunzytomerischer Assay (EASIA-Kit KAC 1261) der Firma BIOSOURCE ${ }^{\circledR}$ wurde zur quantitativen Bestimmung von Interleukin-6 (IL-6) im Serum von C. jacchus verwendet.

Von den im Kit enthaltenden Standards und den Kontrollen wurden Doppelbestimmungen durchgeführt. Da es sich bei den Proben um Primatenserum handelte, das Kit aber für humane Proben entwickelt worden ist, wurden die Proben in drei Verdünnungsstufen (unverdünntes Serum, 1:2 und 1:4) mit dem mitgelieferten Verdünnungsmedium (Lösung A) angesetzt. Von den höchsten beiden (unverdünntes Serum und 1:2) wurden ebenfalls Doppelbestimmungen, von der niedrigsten (1:4) Verdünnungsstufe wurde nur eine Einfachbestimmung durchgeführt.

Alle Reagenzien sind zuerst auf Raumtemperatur gebracht und z.T. entsprechend den Angaben des Herstellers gelöst worden.

$50 \mu 1$ der Lösung B wurden in alle vorgesehenen Vertiefungen der 96-wellMikrotiterplatte gegeben.

In die betreffenden Vertiefung der Titerplatte wurden $100 \mu 1$ der Kontrolle, Standard und Proben pipettiert und bei Raumtemperatur auf einem horizontalen Schüttler bei 15 $\mathrm{g}$ inkubiert.

Anschließend wurde die Flüssigkeit mit Hilfe eines ELISA-Washers (Tecan) aus den wells entfernt und die Platte ebenfalls mit dem ELISA-Washer mit der Waschlösung gespült. Die Platte wurde danach möglichst trocken geschlagen.

$200 \mu \mathrm{l}$ Chromogensubstrat sind in jedes wells gegeben worden und die Platte wurde für 15 Minuten bei Raumtemperatur auf einem horizontalen Schüttler unter Vermeidung von Lichteinfluß inkubiert.

Die Chromogenreaktion wurden anschießend durch die Zugabe von $100 \mu 1 /$ well Stoplösung beendet.

Die Extinktion wurde sofort mit einem ELISA-Reader (Tecan) bei $490 \mathrm{~nm}$ gemessen. 


\subsubsection{Interleukin-1 beta-Assay}

Ein Quantikine ${ }^{\circledR}$ HS human IL-1 $\beta$ Immunoassay (HSLB 50) der Firma R\&D Systems ${ }^{\circledR}$ wurde zur quantitativen Bestimmung von Interleukin-1 $\beta$ (IL-1 $\beta$ ) im Serum von $C$. jacchus verwendet.

Da es sich bei diesem Kit ebenfalls um ein Testsystem zur Messung von humanem IL$1 \beta$ handelte und die Sensitivität bezüglich der Primatenserumproben nicht bekannt war, wurden verschiedene Konzentrationen der Proben (unverdünnt, 1:2, 1:4, 1:8 und 1:16) eingesetzt.

Die im Kit enthaltenen Standards wurden in Doppelbestimmungen, die einzelnen Verdünnungsstufen der Proben hingegen in Einzelbestimmungen durchgeführt.

Alle Reagenzien wurden zunächst auf Raumtemperatur gebracht und z.T. entsprechend den Angaben des Herstellers gelöst.

$100 \mu 1$ Assay-Verdünnungspuffer wurden in jedes well vorgelegt. Dazu wurden dann jeweils $150 \mu 1$ Standard bzw. Probe gegeben.

Nach eine Inkubation von 16 Stunden wurde die Platte mit Hilfe eines ELISA-Washers mit dem Waschpuffer 4 mal gewaschen.

Es folgte die Zugabe von $200 \mu$ Konjugat und eine Inkubation von 3 Stunden bei Raumtemperatur.

Anschließend erfolgte eine weitere vierfach Waschung und die Zugabe von $50 \mu 1$ Substrat-Lösung.

Nach einer Inkubationszeit von 45 Minuten bei Raumtemperatur wurden $50 \mu \mathrm{l}$ Amplifizier-Lösung in jedes well gegeben und wieder 45 Minuten bei Raumtemperatur inkubiert.

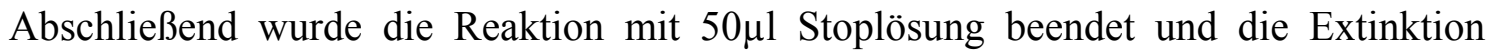
sofort bei $490 \mathrm{~nm}$ im ELISA-Reader gemessen.

\subsubsection{TNF-alpha Assay}

Ein Rhesus-Monkey-Immunoassay-TNF- $\alpha$-Kit (mkTNF- $\alpha$ ELISA-Kit KPC3012/KPC 3011) der Firma BIOSOURCE ${ }^{\circledR}$ wurde zur quantitativen Bestimmung von TumorNecrosis-Faktor-alpha (TNF- $\alpha$ ) im Serum von C. jacchus verwendet. 
Wie vorgeschrieben wurden von den im Kit enthaltenden Standards und Kontrollen Doppelbestimmungen durchgeführt.

Die Proben wurden in drei Verdünnungsstufen (unverdünnt, 1:2 und 1:4) angesetzt. Von den höchsten beiden (unverdünnt und 1:2) wurden ebenfalls Doppelbestimmungen, von der niedrigsten (1:4) Verdünnungsstufe wurde nur eine Einfachbestimmung durchgeführt.

Alle Reagenzien sind zuerst auf Raumtemperatur gebracht und z.T. entsprechend den Angaben des Herstellers gelöst worden.

Zuerst wurden $50 \mu 1$ Inkubationspuffer in jedes well vorgelegt.

$100 \mu \mathrm{l}$ Standard wurden in die betreffenden Vertiefungen pipettiert. In die für die Proben vorgesehenen Vertiefungen wurden zunächst $50 \mu$ l Standard-VerdünnungsPuffer gegeben und dann $50 \mu 1$ der Probe.

Vorsichtig wurde die Platte gemischt und für 2 Stunden bei $37{ }^{\circ} \mathrm{C}$ im Thermoschrank gelagert.

Nach der anschließend erfolgten vierfacher Waschung mit Hilfe des ELISA-Washers wurden $100 \mu \mathrm{l}$ Biotin-Konjugat zugegeben und für 1 Stunde bei Raumtemperatur inkubiert.

Wieder wurde ein vierfacher Waschschritt durchgeführt und dann erfolgte die Inkubation mit $100 \mu \mathrm{l}$ Streptavidin-HRP-Arbeits-Lösung für 30 Minuten bei Raumtemperatur. Die Reste der Arbeitslösung wurden in einem erneuten Waschschritt entfernt.

Zur Auslösung der Farbreaktion sind $100 \mu$ l Chromogen-Lösung pipettiert und für 30 Minuten bei Raumtemperatur inkubiert worden.

Um die Farbreaktion zu beenden wurden $100 \mu$ l Stoplösung hinzugegeben.

Mit dem ELISA-Reader sind die Extinktionen bei 450nm gemessen worden.

\subsubsection{Auswertung der Assay-Messungen}

Die Auswertung der Assay-Messungen erfolgte über die Eingabe der Daten in das GraphPad Prism 3 Programm der Firma GraphPad Software, Inc.

Die statistische Auswertung erfolgte über einen zweiseitigem t-Test, bei der die Proben der $\mathrm{NaCl}$ behandelten Tiere als Kontrolle betrachtet wurden. 


\subsection{Präparation der Gehirne}

Nach Entnahme der Gehirne in den Sektionen wurden diese auf einer tiefgekühlten Metallplatte dorsal, d.h. mit dem Cortex nach unten, schockgefroren und dafür mit Trockeneispulver bedeckt. Zur Aufbewahrung wurden die Gehirne vorsichtig in ein Plastikgefäß gelegt und sofort auf Trockeneis gekühlt. Die Gehirne wurden bei $-70{ }^{\circ} \mathrm{C}$ gelagert.

Zur besseren Bearbeitung sind die Gehirne in 8 Blöckchen geteilt worden. Hierfür wurden die Gehirne dorsal (mit der Oberseite) nach unten mit Tissue Teck $^{\circledR}$ (Sakura) auf dem Präparateteller eines Frigomobils (Reichert-Jung) aufgefrohren. Die Schnittebenen wurden mit Hilfe einer Mikrotom-Einwegklinge (Leica) bei einer Temperatur von $-12{ }^{\circ} \mathrm{C}$ wie folgt durchgeführt: zunächst längs in der Mitte (mitsagital) und danach beide Hälften je 3 mal quer: nach der frontal Region (frontocipital), in der Mitte der medialen Region und kurz vor Ende der medialen Region (Abb.4).

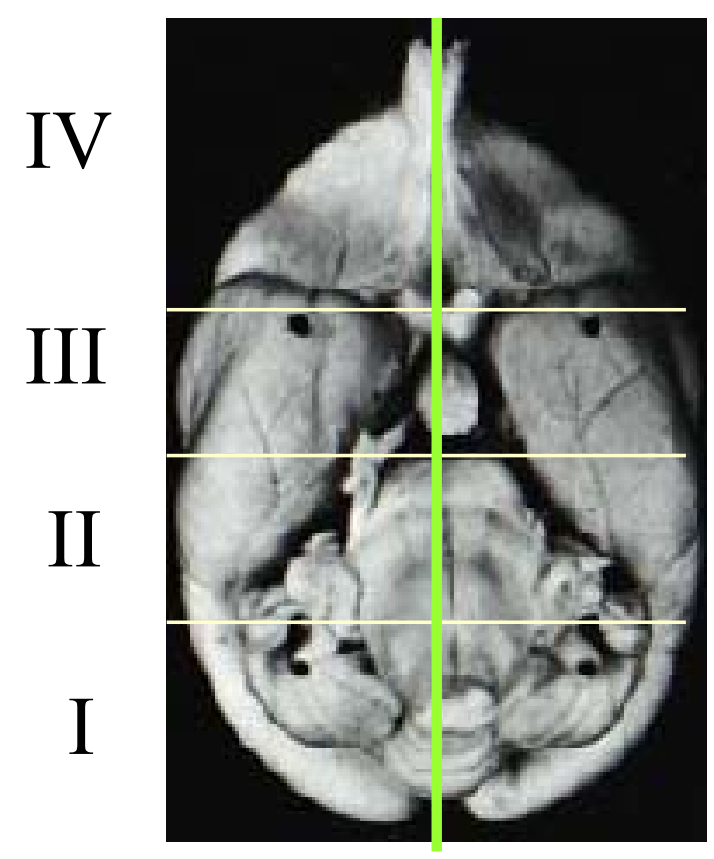

Abb.4: Schnittebenen durch das C.jacchus Gehirn modifizierte Abbildung basierend auf dem stereotaktischen Atlas „The Brain of the Common Marmoset“" (Stephan et al. 1980)

Die Blöckchen (je 2 mal 4 pro Gehirn Nr. I-IV rechts und links) wurden in einer 12-well Zellkulturplatte wieder bei $-70{ }^{\circ} \mathrm{C}$ bis zur weiteren Bearbeitung zwischengelagert.

An den rechten Hirnblöckchen (I-IV) wurden die histologischen und an den linken Hirnblöckchen (II und III) wurden die molekularbiologischen Untersuchungen durchgeführt. 


\subsection{Herstellung der Paraffin- und Gefrierschnitte}

Um die Proben histologisch zu bearbeiten wurden sowohl Gefrierschnitte wie auch Paraffinschnitte hergestellt.

\subsubsection{Herstellung der Paraffinschnitte}

Zur Fixierung wurden die gefrorenen Hirnblöckchen in Einbettkasetten (Firma Sarsted) für 30 bis 40 Minuten in eine $4 \%$ Paraformaldehydlösung gelöst in $0.01 \mathrm{M}$ Phosphatpuffer (PBS) pH 7.6 gegeben.

Nach der erfolgter Fixierung wurden die Proben für ca. 30 Minuten mit Leitungswasser gewässert und anschließend in den Probenkontainer der Gewebeinfiltrationsmaschine (Leica) überführt. Nach den in Tabelle 3 angegebenen Inkubation und Zeiten wurden die Proben in Paraffin (Polarit, Süsse) überführt und an einer Paraffinausgießstation (Leica) in Blöckchen gegossen. Diese wurden dann auf einer Kühlplatte (Leica) gekühlt, bis das Paraffin fest geworden war.

Tab.3: Inkubationsprogramm der Gewebeinfiltrationsmaschine

\begin{tabular}{|c|c|c|c|}
\hline Medium & Zeit & Medium & Zeit \\
\hline $60 \%$ Ethanol & 1 Stunde 20 Minuten & $100 \%$ Ethanol & 1 Stunde 20 Minuten \\
\hline $70 \%$ Ethanol & 1 Stunde 20 Minuten & $100 \%$ Ethanol & 1 Stunde 20 Minuten \\
\hline $70 \%$ Ethanol & 1 Stunde 20 Minuten & Xylol & 1 Stunde 20 Minuten \\
\hline $90 \%$ Ethanol & 1 Stunde 20 Minuten & Xylol & 1 Stunde 20 Minuten \\
\hline $90 \%$ Ethanol & 1 Stunde 20 Minuten & Paraffin & 1 Stunde 00 Minuten \\
\hline $100 \%$ Ethanol & 1 Stunde 20 Minuten & Paraffin & 1 Stunde 00 Minuten \\
\hline
\end{tabular}

Die so erhaltenen Probenblöckchen von zwei mit LPS- (Tier 3 und 4) und zwei mit NaCl-behandelten (Tier 1 und 2) Tieren wurden mit einem Rotationsmikrotom (Leica) unter der Verwendung von Einwegklingen (Leica) in $5 \mu \mathrm{m}$ dünne Scheiben (Schnitte) geschnitten.

Die Schnitte wurden auf SuperFrost Objektträger (Menzel) mit einer positiven Beschichtung, auf die ein Wassertropfen zur Streckung des Paraffinschnittes aufgebracht war, aufgezogen. Nach jeweils 10 Objekträgern wurden die nächsten 10 Schnitte auf Spezialobjektträger (DakoCytomation) mit derselben Beschichtung 
aufgezogen. Diese speziellen Objektträger waren für eine Färbung mit dem TechMate ${ }^{\mathrm{TM}}$ Immunautostainer der Firma DakoCytomation geeignet.

Zur endgültigen Streckung der Paraffinschnitte wurden die Objektträger auf eine $37^{\circ} \mathrm{C}$ Wärmeplatte (Leica) gestellt. Nach ca. 10 bis 15 Minuten und einer deutlichen Streckung der Schnitte wurde das Wasser vorsichtig abgegossen. Die anschließende Trocknung erfolgte im Thermoschrank bei $37^{\circ} \mathrm{C}$ für mindestens 24 Stunden, damit die Schnitte gut am Objektträger hafteten.

\subsubsection{Herstellung der Gefrierschnitte}

Für die Arbeit mit den gefrorenen Hirnblöckchen war es notwendig, die Objekträger (einfach Glas, Menzel), sowie die Lagerungsschachteln und sämtliche Instrumente mit Trockeneis zu kühlen, um so ein Auftauen der Proben zu verhindern.

Von den gefrorenen linken Blöckchen (I-IV der Abb. 4) der 14 Gehirne wurden jeweils die beiden mittleren (II und III) wie folgt bearbeitet.

Der Block wurde mit TissueTek ${ }^{\circledR}$ O.C.T. ${ }^{\mathrm{TM}}$ Compound (histologischer Klebstoff, Sakura) auf ein Frigomobil (Reichert-Jung) aufgefroren $\left(-25^{\circ} \mathrm{C}\right)$ und mit einer im $10^{\circ}$ Winkel stehenden Mehrweg-C-Mikrotomklinge (Leica) bei einer Temperatur von $\sim-12{ }^{\circ} \mathrm{C}$ komplett in $500 \mu \mathrm{m}$ Scheiben geschnitten. Je drei Schnitte wurden zusammen auf einen vorgekühlten Objektträger aufgezogen. Damit sie fest auf dem Objektträger hafteten sind die Schnitte kurz angetaut und dann sofort auf Trockeneis gekühlt worden.

Die Lagerung erfolgte bei $-70{ }^{\circ} \mathrm{C}$.

\subsection{Histologische Untersuchungen}

Für die morphologische Betrachtung des Gehirns wurden zunächst HämatoxilinEosin(HE)-Färbungen an den rechten Gehirnhälften von Tier 1-4 durchgeführt.

Die Lokalisation mRNA-Expressiongebiete erfolgte mittels in-situ-Hybridisierungen.

Der Proteinnachweis erfolgte über immunhistologische Nachweismethoden. 


\subsubsection{Hämatoxilin-Eosin-Übersichtsfärbungen}

Zur Übersicht und Orientierung innerhalb der Schnitte wurden zunächst HämatoxilinEosin-Färbungen (HE) angefertigt.

In dieser Färbung werden Kerne und muköse Substanzen blau dargestellt. Zytoplasma der Zellen, Kollagene hingegen erscheinen blau-rot.

Mit Hilfe des Dako TechMate ${ }^{\mathrm{TM}}$ Horizon 500 wurde jeder 20. Schnitt aus den etwa 12000 angefertigten Paraffinschnitten der rechten Gehirnhälften (alle $100 \mu \mathrm{m}$ ) HE (Maschinenprotokoll siehe Anhang) gefärbt.

\subsubsection{Prinzip des TechMate ${ }^{\mathrm{TM}}$ Horizon}

Diese Maschine färbt mit Hilfe der Kapillarspalttechnik. Dazu werden zunächst spezielle Objektträger (DakoCytomation) benötigt, die als Beschriftungsfeld und in den gegenüberliegenden Ecken eine in der Dicke genau festgelegte Teflonbeschichtung haben. Zwei dieser Objektträger, je mit einem Präparat versehen, bilden, mit den Teflonbeschichtungen zueinander, zusammen gelegt einen Kapillarspalt. Dieser ist je nach verwendeten Objektträgern für Paraffinschnitte $75 \mu \mathrm{m}$ oder für Gefrierschnitte 100 $\mu \mathrm{m}$ groß. Aber auch mit gewöhnlichen Objektträgern (Super Frost Plus) kann die Maschine genutzt werden. Für sie gibt es spezielle gelbe Objektträger, die, ohne Präparat, mit einem gewöhnlichen Objektträger, auf die ein Präparat aufgezogen wird, zusammen einen Spalt von $155 \mu \mathrm{m}$ bilden.

Der TechMate ${ }^{\mathrm{TM}}$ Horizon 500 verfügt über einen in zwei Einheiten unterteilten Objektträgerhalter. Jeder dieser Einheiten kann hochkant 10 Objektträgerpaare aufnehmen. Dadurch können in einem Durchlauf maximal 40 Objektträger gefärbt werden. Der Objektträgerhalter wird in einen Schwenkarm eingeschoben, der senkrecht über die einzelnen Reagenziengefäße fährt und sich mit den Objektträgern vorsichtig absenkt. Nach einem im Programm festgelegtem Ablauf fährt die Maschine für die einzelne Inkubationsdauer die einzelnen Reagenzien an. Durch den Kapillarspalt werden die Reagenzien über die Schnitte gezogen. Nach jedem Schritt mit einer Reagenz fährt der Arm auf ein Saugkissen (Wattepad), wo, durch die Berührung mit dem Saugkissen die Reagenz über den Kapillarspalt abgesaugt wird. 
Aufgrund der Präzision der Maschine, was Färbedauer und Reagenzienmenge angeht, kann eine gleichmäßige Färbung erreicht werden. Zudem benötigt die Maschine aufgrund der Kapillarspaltmethode erheblich weniger Reagenz als die Handfärbung.

Es wurden spezielle ChemMate ${ }^{\mathrm{TM}}$-Reagenzien der Firma DakoCytomation für den TechMate ${ }^{\mathrm{TM}}$ Horizon verwendet:

$>$ Saugkissen (Wattepads) für TechMate 500

$>$ Reagenziengefäße für TechMate ${ }^{\mathrm{TM}}$ Färbeautomaten (mit je 10 Vertiefungen)

$>$ Dako ChemMate ${ }^{\mathrm{TM}}$ Hämatoxilin (gebrauchsfertig)

Je $500 \mu \mathrm{l}$ pro Vertiefung wurden von den Reagenzien pipettiert. Das genaue Protokoll mit allen einzelnen Schritten wurde im Anhang aufgelistet.

\subsubsection{Molekularbiologische Verfahren}

Das Ausgangsmaterial für die in der Arbeit benutzten Nachweismethoden (PCR und insitu-Hybridisierung) ist RNA. Um eine Polymerase-Kettenreaktion (Polymerase-ChainReaction, PCR) durchführen oder eine in-situ-Sonde konstruieren zu können, benötigt man komplementäre Desoxyribonucleinsäure (cDNA). Von bei $-70{ }^{\circ} \mathrm{C}$ eingelagerten Testgehirn-Proben (,Waster“, Herkunft DPZ) wurde aus dem Hypothalamus zunächst total-Ribonucleinsäure (RNA) isoliert, um so Ausgangsmaterial für die PCR, in-situHybridisierungssonden und die Taqman-PCR zu erhalten.

\subsubsection{RNA-Gewinnung}

Beim Arbeiten mit RNA galten strenge Bedingungen. Die gesamten Arbeitsschritte wurden auf Eis und unter möglichst sterilen (RNAse freien) Bedingungen durchgeführt. Sämtliche Materialien sind entweder bei $240{ }^{\circ} \mathrm{C}$ für 12 Stunden sterilisiert (z.B. Glasgefäße) oder bei $120{ }^{\circ} \mathrm{C}$ für 30 Minuten autoklaviert worden. Alle Lösungen wurden mit $0.1 \mathrm{ml}$ Velcorin ${ }^{\circledR}$ (Dimethylpyrocarbonat, Bayer Leverkusen), als Ersatz für DEPC, pro $100 \mathrm{ml}$ Lösung für mindestens 31/2 Stunden inkubiert und anschließend autoklaviert. Alle Reagenzien, die nicht autoklaviert werden können, weil sie dadurch zerfallen, wurden als RNAse-freie Stammlösungen erworben und anschließend zum Gebrauch mit sterilem Velcorin ${ }^{\circledR}$-Wasser verdünnt. 
Zur Isolierung der total-RNA ist das RNeasy ${ }^{\circledR}$-Kit der Firma Qiagen verwendet worden. Dabei wurden zunächst Hypothalamusgewebestücke von ca. 100 bis $200 \mathrm{mg}$ in $50 \mu 1$ Lysispuffer (RLT-Puffer: Puffer mit $10 \quad \mu \mathrm{l} \quad \beta$-Mercaptoethanol pro $1 \mathrm{ml}$ ) bei Raumtemperatur mit einer sterilen Kanüle in einem $2 \mathrm{ml}$ Microröhre (Eppendorf-Cup, E-Cup) zerkleinert. Anschließend wurden $450 \mu$ RLT-Puffer zugegeben, daß E-Cup gevortext und in einem Ultraschallbad für $\sim 10$ Sekunden homogenisiert.

Dieses Homogenisat ist auf eine Schreddersäule (Schredderkit, Qiagen) gegeben und bei $10.000 \mathrm{~g}$ zentrifugiert worden, um störende Gewebefragmente zu entfernen. $\mathrm{Zu}$ den $500 \mu 1$ Eluat wurde die gleiche Menge, also $500 \mu 170$ \% Ethanol (J.T.Baker) zugegeben, gemischt und $500 \mu 1$ dieser Mischung auf die RNeasy-Säule gegeben. Für 15 Sekunden wurde diese Säule bei 10.000 g zentrifugiert. Dieser Vorgang wurde ein zweites Mal wiederholt. In dieser Zeit bindet die RNA an die Säule. Nach dem Leeren des Tubes wurde die Säule mit $500 \mu 1$ Waschpuffer (RW 1) bei 10.000 g für 15 Sekunden gespült. Die Säule wurde in ein neues Tube überführt und zweimal mit $500 \mu 1$ RPE-Puffer gewaschen, um ungebundene Stoffe zu entfernen. Beim ersten Mal ist die Säule wieder bei $10.000 \mathrm{~g}$ für 15 Sekunden zentrifugiert worden, beim zweiten Mal wurde sie bei $10.000 \mathrm{~g}$ für 2 Minuten komplett trocken zentrifugiert.

Schließlich wurde die Säule auf ein steriles $1.5 \mathrm{ml}$ E-Cup gesetzt und die in der Säule enthaltene RNA durch die Zugabe von $50 \mu 1$ RNAse-freies Wasser und einer Zentrifugationsdauer von 60 Sekunden bei 10.000 g herausgelöst. Die Säule wurde verworfen und die gewonnene RNA sofort auf Eis gekühlt. Zur Bestimmung der RNAKonzentration ist eine Verdünnung von 1:16 (5 $\mu$ l RNA plus $75 \mu 1$ RNAse-freies Wasser) erstellt worden. Diese Verdünnung wurde an einem Photometer (Eppendorf) gemessen.

Die gewonnene RNA wurde zur weiteren Verarbeitung bei $-70{ }^{\circ} \mathrm{C}$ zwischengelagert.

\subsubsection{Reverse Transkriptase (RT)}

Um eine PCR durchführen zu können, wird cDNA benötigt. Die, wie im oben genannten Verfahren beschrieben, gewonnene totale RNA wurde mit Hilfe des Enzyms Reverse Transkriptase in DNA umgeschrieben, um diese in einer anschließenden PCR zu vermehren. 
Bei der verwendeten RT handelte es sich um eine murine retrovirale RT (M-MLV RT RNAse Hminus Point Mutant, Promega), die keine RNAseaktivität aufweist.

Oligo-dt-Primer (GibcoBRL, Life Technologies) wurden eingesetzt, um einen Startpunkt für die RT zu erhalten. Zur Synthese der DNA wurde ein 10 mM dNTP-Mix der Firma GibcoBRL (Life Technologies) zugegeben.

Nach folgendem Ansatz wurde die RT für ein Endvolumen von $20 \mu 1$ pipettiert:

$1 \mu 1$ RNA (Hypothalamus, C. jacchus) sind mit $12 \mu 1$ Velcorinwasser und $1 \mu 1$ Oligo-dtPrimern gemischt, kurz herunterzentrifugiert und für 10 Minuten bei Raumtemperatur inkubiert worden. In diesen 10 Minuten erfolgte die Anheftung der Primer (Annealing) bei einer Temperatur von $22{ }^{\circ} \mathrm{C}$. Insgesamt $6 \mu$ l Master-Mix, bestehend aus $4 \mu \mathrm{M}$ MLV RT 5 x Reaktionspuffer, $1 \mu$ dNTP-Mix und $1 \mu$ RT (plus $1 \mu$ RNAsin/10 Ansätze) wurden zu jedem Ansatz gegeben, vermischt und herunterzentrifugiert.

Anschließend erfolgte die Inkubation im Thermocycler T3 (Biometra ${ }^{\circledR}$ ) unter folgenden Bedingungen:

Die Gegenstrangsynthese (Polymerisation) fand innerhalb von 50 Minuten bei $42{ }^{\circ} \mathrm{C}$ statt. Zur Denaturierung wurden die Ansätze für 10 Minuten bei $95{ }^{\circ} \mathrm{C}$ inkubiert.

Die cDNA wurde sofort nach Beendigung des letzten Inkubationsschrittes auf Eis gekühlt, herunterzentrifugiert und bei $-20{ }^{\circ} \mathrm{C}$ eingefroren.

\subsubsection{Sequenzsuche und Sequenzabgleich}

Sowohl für die PCR, die in-situ-Hybridisierungssonden, als auch für die TaqMan-PCR wurden geeignete Primer benötigt. In der Literaturdatenbank z.B. PubMed waren keine spezifischen Primer und Sequenzen für C. jacchus zu finden. Daher war es nötig nach folgendem Verfahren vorzugehen:

\subsection{Sonden und Primer für die in-situ-Hybridisierung}

In den frei zugänglichen Datenbanken (z.B. PubMed Nucleotide) waren keine Sequenzen für IL-1 $\beta$, IL-1ra, IL-1RI und IL-1RII von $C$. jacchus vorhanden. Zur Primer- und Sondensuche mußten Interleukinsequenzen von anderen Tieren und des Menschen herangezogen werden. Für IL-1 $\beta$ sind Sequenzen von Mensch und Affe, für 
IL-1ra von Mensch, Delphin, Kaninchen und Pferd, für IL-1RI von Mensch, Pferd, Maus und Ratte und für IL-1RII von Mensch und Maus über PubMed aus dem Internet bezogen und mit Hilfe des Softwareprogramms DNAsis (Pharmacia) verglichen worden. Für die Sonden wurde eine Mindestlänge von 200 Basenpaaren (base pairs, bp) und einer Maximallänge von 600 bp vorgegeben. Mit dieser Vorgabe sind geeignete Primerpaare (antisense und sense) gesucht worden. Die in der Literatur genannten Primer für die diversen Sequenzen anderer Spezies wurden auf ihre Verwendungsmöglichkeit überprüft. Es ergaben sich jedoch keine geeigneten Primer, die eine möglichst große Übereinstimmung in den Sequenzen der einzelnen Tiere bzw. des Menschen hatten. In den einzelnen Sequenzvergleichen wurden für IL-1 $\beta$, IL-1ra, IL-1RI und IL-1RII in den nahezu homologen Sequenzabschnitten Primer mit einer Mindestlänge von 20 bp (max.24 bp) gesucht. Die so gewählten Primer wurden unter der Verwendung der G/C-Regel ( 50 \%iger G/C-Gehalt mit zufälliger Basenverteilung) überprüft und bei Bedarf (AT und GC reiche Regionen, Polypurine und Polypyrimidine möglichst meiden; keine komplementären Strukturen in den Primerpaaren) verworfen. Alle übrig gebliebenen Primer sind mit Hilfe von PubMed Blast auf ihre Spezifität für z.B. IL-1 $\beta$ überprüft worden. Mehrere Kombinationen (Tab.4) wurden für IL-1 $\beta$, IL-1ra, IL-1RI und IL-1RII gefunden, bei Eurogentec bestellt. Nach Lösung der lyophylisierten Primer wurden diese in Aliquots bei $-20{ }^{\circ} \mathrm{C}$ gelagert und schließlich unter verschiedenen PCR-Bedingungen getestet.

Tab.4: Primer und Sequenzlänge

grün: ausgesuchte Primer zur Sondenkonstruktion

\begin{tabular}{c|c|c|c|c} 
Sequenz & sense & antisense & Länge & PCR \\
\hline IL-1 $\beta$ & S 3: gat ggc cet aa cag atg aa & AS 3: atc tac act ctc cag ctg ta & 528 bp & positiv \\
\hline IL-1ra & S 1: ctt cag aat ctg gga tgt ta & AS 10: ctg gaa gta gaa ttt ggt ga & 412 bp & negativ \\
\hline & S 3: aac caa cta gtt gct gga ta & AS 10: ctg gaa gta gaa ttt ggt ga & 366 bp & positiv \\
\hline IL-1RI & S 1: tgg tat aaa gat gac aga aa & AS 7: gac cca ttc cac ttc cag ta & 626 bp & positiv \\
\hline & S 3: tgg agg att cag gac att ac & AS 7: gac cca ttc cac ttc cag ta & 532 bp & positiv \\
\hline IL-1RII & S 1: tgg ctt ctg cca gec ttg ca & AS 9: tgt gcc ggt tcc cag aaa ca & 519 bp & positiv \\
\hline & S 4: tag tat gcc ctg acc tga gt & AS 9: tgt gcc ggt tcc cag aaa ca & 350 bp & negativ \\
\hline & S 6: ggc cag caa tac aac atc ac & AS 15: gag gct tcc ttg act gtg gt & 392 bp & negativ \\
\hline & S 6: ggc cag caa tac aac atc ac & AS 18: cac cgt ctg tgc atc cat at & 476 bp & negativ
\end{tabular}




\subsubsection{Polymerase-Kettenreaktion (PCR)}

Die Methode beruht auf dem Prinzip der DNA-Vervielfältigung durch eine Polymerase. Selbst eine kleine DNA-Menge ermöglicht in kürzester Zeit eine effektive Amplifikation (Mullis et al. 1986). Dieser Vorgang gliedert sich in drei Schritte, die zyklisch durchlaufen werden, und läßt sich theoretisch beliebig wiederholen (chain reaction).

Ausgangsmaterial für die PCR ist also DNA. Aufgrund seiner chemischen Struktur hat jeder Einzelstrang eine Richtung. Im Doppelstrang verlaufen diese gegeneinander, aber immer in 5'-3'-Richtung. Zuerst wird die DNA bei $94{ }^{\circ} \mathrm{C}$ denaturiert, d.h. der Doppelstrang schmilzt zu Einzelstrang-DNA auf. Im zweiten Schritt, beim sogenannten annealing bei $54{ }^{\circ} \mathrm{C}$, lagern sich die Oligonucleotidprimer (kurze einsträngige DNAMoleküle) mit den beiden Matritzensträngen zusammen (hybridisieren). Die Primer bestimmen nach dem erstem Amplifikationsschritt nicht nur den Anfang, sondern auch das Ende des DNA-Abschnittes, der vervielfältigt werden soll. Bei $70{ }^{\circ} \mathrm{C}$ (ideale Arbeitstemperatur der Polymerase) erfolgt nun im dritten Schritt die Polymerisation, bei der die Primer, die durch ihre Bindung einen doppelsträngigen Bereich schaffen, der DNA-Polymerase (koppelt dNTP's von 5' nach $3^{\text {‘ }}$ aneinander) als Startpunkt zur Kopierung der Matritzenstränge dienen. Von Zyklus zu Zyklus (30 bis $40 \mathrm{x}$ ) verdoppelt sich die vorhandene Menge der DNA-Sequenz, die von den Primern eingefaßt ist (exponentielles Wachstum), da jeder neu synthetisierte doppelsträngige DNA-Abschnitt als Matrize dient.

Um die Reaktion durchzuführen, wurde eine thermostabile Taq-Polymerase benutzt, die ursprünglich aus dem Bakterium Thermophilus aquaticus isoliert wurde (Chien et al. 1976). Dieses Enzym verträgt auch eine Temperatur von $95^{\circ} \mathrm{C}$. Dadurch ist es während der Denaturierungsphase der DNA stabil und bleibt auch bei der nachfolgenden Polymerisation und erneuter Wiederholung der einzelnen Schritte reaktiv. Zudem arbeitet dieses Enzym mit einer hohen Geschwindigkeit, was auch eine Vermehrung größerer DNA-Fragmente ermöglicht.

Die unter 2.5.2.1 in Tabelle 4 beschriebenen Primer wurden unter verschiedenen PCRBedingungen (annealing $54{ }^{\circ} \mathrm{C}, 56{ }^{\circ} \mathrm{C}, 58{ }^{\circ} \mathrm{C}$ oder $60{ }^{\circ} \mathrm{C}$ ) getestet. Diese Temperaturen wurden über die sogenannte 4+2-Regel (für jedes Cytosin und Guanin wird $4{ }^{\circ} \mathrm{C}$, für jedes Adenin und Thymidin wird $2{ }^{\circ} \mathrm{C}$ gezählt) ermittelt. Die Summe ergibt die ungefähre annealing-Temperatur. 
Der PCR-Ansatz wurde wie folgt pipettiert:

Für jeden Ansatz wurden Doppelbestimmungen vorgenommen. Der $50 \mu 1$ Ansatz wurde aus $2 \mu \mathrm{l}$ cDNA, $45 \mu 1$ PCR-Supermix (Invitrogen), $2.5 \mu 1$ Velcorin-Wasser, $0.25 \mu 1$ sense (5‘ Primer 50pmol) und $0.25 \mu \mathrm{l}$ antisense Primer ( $3^{\circ}$ Primer $50 \mathrm{pmol}$ ) in speziellen, dünnwandigen PCR-E-Cups zusammengestellt und mit $40 \mu 1$ PCR-Wachs abgedeckt, um so ein kondensieren des Ansatzes im Deckel zu verhindern.

Die PCR-Ansätze wurden in einem Thermocycler (Trio-Thermoblock, Biometra) mit folgendem Programm inkubiert:

$\begin{array}{llll}\text { 1. } & 94{ }^{\circ} \mathrm{C} & 3 \mathrm{~min} & \text { erste Denaturierung der DNA } \\ \text { 2. } & 94{ }^{\circ} \mathrm{C} & 1 \mathrm{~min} & \text { Denaturierung der DNA } \\ \text { 3. } & 54{ }^{\circ} \mathrm{C} \text {, oder } 56{ }^{\circ} \mathrm{C}, & 90 \mathrm{sec} & \text { Annealing der Primer } \\ & \text { oder } 58{ }^{\circ} \mathrm{C} \text { oder } 60{ }^{\circ} \mathrm{C} & \\ \text { 4. } & 72{ }^{\circ} \mathrm{C} & 90 \mathrm{sec} & \text { Synthese des Gegenstrangs }\end{array}$

Nach Punkt 4 erfolgte der Schritt zu Punkt 2. Dieser Zyklus wurde 31 mal wiederholt, bevor das Programm mit Punkt 5 weiter fortgesetzt wurde.
5. $\quad 72{ }^{\circ} \mathrm{C}$
$10 \mathrm{~min}$
Schlußsynthese
6. $\quad 4^{\circ} \mathrm{C}$
Pause
Lagerungstemperatur

Nach Ablauf der PCR-Reaktion wurden $1 \mu \mathrm{l}$ des PCR-Produktes (Rest wurde bei -20 ${ }^{\circ} \mathrm{C}$ eingefroren) mit $2 \mu$ l Stop-Puffer und $9 \mu$ A Ampuwa gemischt. Diese Proben sind zusammen mit der negativen Kontrolle (Ampuwa) und einer 100 bp DNA-Leiter (DNALösung mit definierten DNA-Bruchstücken, Invitrogen) auf ein 1.5 \%iges 16-TaschenAgarose-Gel in einer Elektrophoresekammer aufgetragen worden. Nach Zugabe von ausreichend 1 x TBS-Puffer (Gel und Elektroden mußten bedeckt sein) ist mit einem Spannungsblock (Biometra) für ca. 1 Stunde eine Spannung von 110 Volt angelegt worden.

Nach der Elektrophorese wurden die Gele in einem Ethidiumbromidbad für 20 Minuten gefärbt.

Mit Hilfe eines digitalen Fotosystems (Kamera und Software; Kodak Programm ds/Digital sciene Version 2.0.3., Eastman Kodak Company) sind Fotos von den Gelen erstellt worden.

Anhand der Banden und mit der ebenfalls aufgetragenen 100 bp DNA-Leiter konnten die Fragmentgrößen abgeschätzt werden. Die erhaltene Bandengröße (Abb.5) wurde mit der zu erwartenden (Tab.4) verglichen. Anhand der unterschiedlichen starken Bande 
derselben Primerkombinationen bei unterschiedlichen PCR-Bedingungen konnten die für diese Kombination besten Bedingungen ermittelt werden (grün unterlegt in Tab.4).

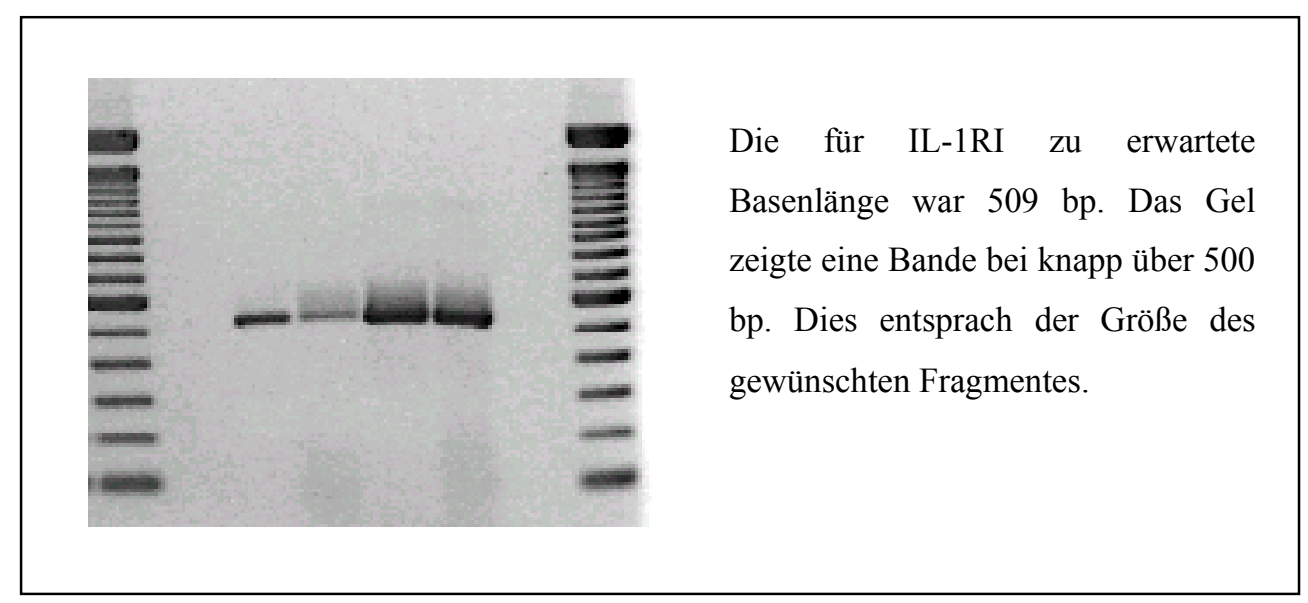

Abb.5: Gelfoto von einem PCR-Gel von IL-1RI mit einer Sequenzlänge von 509 bp

\subsubsection{On-shot-Transformation}

Zur Herstellung einer in-situ-Sonde wird ein Verfahren benutzt, in dem das PCRProdukt (Teilsequenz mit Primern, 2.5.2.4) in ein Plasmid eingeschleust, dieses mit Hilfe einen Bakteriums, hier Escherichia coli (E.coli), als Klon (identische Kopie einer Zelle) vermehrt und so in größeren Mengen angereichert wird.

Da für die PCR eine Taq-Polymerase verwendet worden ist und das PCR-Produkt somit einen einzelnen $3^{4}$-A Überhang an jedem Ende aufweist, wurde hier ein Plasmid aus dem TOPO TA Cloning ${ }^{\text {TM }}$ Kit (Invitrogen) verwendet. Dieses Plasmid besitzt eine genau definierte Region, d.h. einem 3'-T Überhang, zum Einbau des PCR-Produktes. An dem 3'-T Überhang ist eine Topoisomerase I (die aus dem Vaccinia Virus gewonnen wurde) gekoppelt, die für den Einbau des PCR-Produktes verantwortlich ist (Shuman 1994). Dieses in Eucaryoten und Procaryoten vorkommende Enzym katalysiert den Einbau der „fremden“ DNA, ohne eine Änderung in der chemischen Zusammensetzung zu verursachen. Nach erfolgreichem Einbau löst sich die Topoisomerase I von der DNA ab.

Zunächst wurden in einem kleinem PCR-E-Cup $2 \mu$ PCR-Produkt mit $1 \mu 1$ der im Kit enthaltenden Salzlösung, $5 \mu 1$ Ampuwa und $1 \mu 1$ pCR TOPO Vektor nach vorsichtigem Mischen für 5 Minuten bei Raumtemperatur inkubiert. Während dieser Zeit wurde das 
PCR-Produkt in den Vektor (Plasmid) eingebaut. Der Ansatz wurde herunterzentrifugiert und sofort auf Eis gelagert.

Um die isolierte DNA in ein Bakterium einzubringen, Transformation genannt, gibt es vier verschiedene Möglichkeiten: 1. Ausnutzung der natürlichen DNAAufnahmebereitschaft (Kompetenz), 2. Induktion der DNA-Aufnahmebereitschaft durch Vorbehandlung der Zellen, 3. Erzeugung von Protoplasten und 4. Elektroporation. Bei der hier verwendeten Methode handelte es sich um die InduktionsMethode mittels Kälte und Wärme.

$2 \mu 1$ des Produktes aus der Klonierungsreaktion wurden für die Transformation in einem E-Cup mit den Top 10 OneShot $^{\mathrm{TM}}$ Zellen (E.coli) für 30 Minuten auf Eis inkubiert. Anschließend erfolgte eine Schockerhitzung des Ansatzes für 30 Sekunden im $42{ }^{\circ} \mathrm{C}$ Wasserbad und dann sofort die Abkühlung auf Eis für 2 Minuten. Zur Vermehrung der Zellen sind bei Raumtemperatur $250 \mu 1$ SOC-Medium hinzugefügt worden. Die Zellen wurden für 30 Minuten bei $37^{\circ} \mathrm{C}$ im Schüttler in horizontaler Lage inkubiert und danach sofort wieder auf Eis gekühlt.

Von diesem Ansatz sind $100 \mu \mathrm{l}$ auf eine auf $37{ }^{\circ} \mathrm{C}$ vorgewärmten LB Amp$_{\text {-Agarplatte }}$ (Agarplatte mit dem Antibiotikum Ampicillin) verteilt worden, die vorher mit $40 \mu 1 \mathrm{X}$ Gal (Galactose) beschichtet worden war. Die Inkubation erfolgte über Nacht bei $37{ }^{\circ} \mathrm{C}$ im Thermoschrank. Von den blauen und weißen Kolonien, die über Nacht auf der Platte gewachsen sind, enthielten nur die weißen Kolonien (aufgrund der Fähigkeit $\beta$ Galactosidase zu produzieren) das Plasmid. Eine dieser Kolonien wurde mit Hilfe eines sterilen Zahnstochers auf eine neue LB-Agarplatte (Stocherplatte) überführt (Zahnstocher in den Agar stechen). Derselbe Zahnstocher wurde in einem vorbereiteten PCR-E-Cup (mit allen Reagenzien für eine PCR, Ansatz unter Punkt 2.5.2.4) kurz gerührt. Die Stocherplatte wurde wieder über Nacht bei $37{ }^{\circ} \mathrm{C}$ inkubiert und von dem jeweiligen Stocher eine Kontroll-PCR (Bedingungen und Auswertung nach dem oben beschriebenen Verfahren) angefertigt, um den Einbau des PCR-Produktes zu überprüfen. Von einem Stocher, der das PCR-Produkt enthält, wurde mit Hilfe einer Impfoese ein erneuter Ausstrich (Reinheitsausstrich) auf einer LB-Agarplatte vorgenommen und wieder über Nacht bei $37^{\circ} \mathrm{C}$ inkubiert. 


\subsubsection{Klonkultur}

Um eine möglichst hohe Plasmidausbeute zu erhalten, war es notwendig einen Klon zu vermehren. Von dem im vorangegangenen Punkt beschriebenen Reinheitsausstrich ist eine Vorkultur angelegt worden. Dazu wurde eine Klonkolonie mit einer sterilen

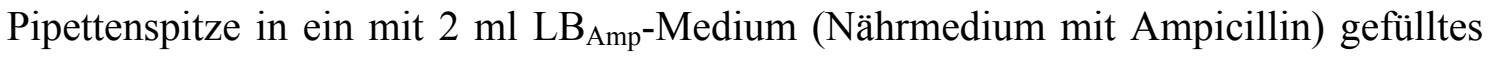
Reagenzröhrchen überführt. Für mindestens 8 Stunden erfolgte eine Inkubation unter Bewegung in einem Thermoschüttler bei $37^{\circ} \mathrm{C}$.

Von der Vorkultur wurden nach Ablauf der Inkubationszeit $200 \mu 1$ entnommen und in

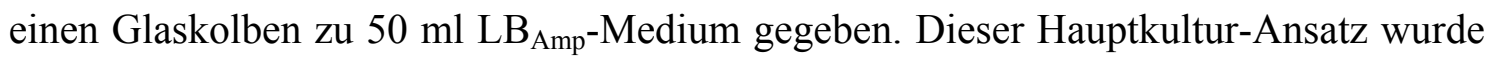
über Nacht bei $37^{\circ} \mathrm{C}$ im Thermoschüttler vermehrt.

\subsubsection{Gewinnung von Vektor DNA durch MidiPrep}

Die Hauptkultur wurde am nächsten Morgen in ein sterilen Behälter (Falcontube) überführt und für 15 Minuten bei $25^{\circ} \mathrm{C}$ und $3000 \mathrm{~g}$ zentrifugiert.

Es entstand ein Bakterienpellet. Der Überstand (klare Nährlösung) wurde dekantiert. Die weitere Aufarbeitung erfolgte mit dem QIAfliter ${ }^{\mathrm{TM}}$ Plasmid MidiPrep-Kit (Qiagen). Das Pellet wurde mit $4 \mathrm{ml}$ Puffer P1, welcher zur Lyse der Zellen dient, durch vorsichtiges auf- und abpipettieren resuspendiert und anschließend mit $4 \mathrm{ml}$ Lysispuffer P2, für 5 Minuten bei RT inkubiert. Durch 10 Minuten Inkubation und Umschütten auf eine QIAfilter Maxi-Cartrige mit dem Puffer 3 wurden die Proteine ausgefällt und beim Überführen auf die mit $4 \mathrm{ml}$ QBT equilibrierte Tip500-Filtersäule durch einen Filter zurückgehalten. Die restliche Lösung passierte eine Filtersäule. Im Filter wurde die DNA gebunden. Nach zwei Waschgängen mit einem Waschpuffer (2 mal $30 \mathrm{ml}$ QCPuffer) wurde die DNA mit $15 \mathrm{ml}$ QF-Puffer (enthält Isopropanol) aus dem Filter gelöst. Die so eluierte DNA ist auf 5 mit $700 \mu$ I Isopropanol gefüllte $2 \mathrm{ml}$ E-Cups verteilt und für 30 Minuten bei $4^{\circ} \mathrm{C}$ und $10.000 \mathrm{~g}$ zentrifugiert worden. Der Überstand wurde dekantiert und das entstandene DNA-Pellet durch die Zugabe von je $1 \mathrm{ml} 70$ \% Ethanol gewaschen und dann erneut bei $10.000 \mathrm{~g}$ und $4{ }^{\circ} \mathrm{C}$ für 10 Minuten zentrifugiert. Der Überstand ist vorsichtig mit einer Pipette entfernt und das Pellet an der Luft getrocknet worden. Die getrocknete DNA wurde mit je $10 \mu \mathrm{l}$ Ampuwa/E-Cup aufgenommen und in einem E-Cup zusammengeführt. Die E-Cups wurden zum 
Abschluß noch einmal mit $10 \mu 1$ Ampuwa gespült. Die Menge der so erhaltene DNA wurde in einer 1:100 Verdünnung am Photometer gemessen und ihre Reinheit bestimmt. $10 \mu \mathrm{l}$ der Verdünnung sind zur Kontrolle auf ein $1 \%$ iges Agarosegel aufgetragen worden. Es zeigten sich drei Bande unterschiedlicher Größen, die für die drei Formen, in denen der Vektor vorliegen kann, typisch sind.

\subsubsection{Sequenzierung}

Für die Sequenzierung wurden aus der unter Punkt 2.5.2.7 gewonnenen Plasmid-DNALösung $\sim 15 \mu 1$ mit einer Konzentration von 200 ng/ $\mu 1$ hergestellt. Die Sequenzierung wurde kommerziell von der Firma Sequence Laboratories GmbH (Göttingen) durchgeführt.

Die so erhaltenen Sequenzen sind mit Hilfe des DNAsis-Programms auf die eingesetzten Primer und die Einbaurichtung des PCR-Produktes überprüft worden. Zudem wurde ein Sequenzabgleich mit den humanen Sequenzen für IL-1 $\beta$, IL-1ra, IL1RI und IL-1RII vorgenommen. Die Übereinstimmung lagen bei über $90 \%$.

\subsubsection{Linearisierung der dsDNA mit dem RiboMax-Kit von Promega}

Unter Zuhilfenahme des RiboMax-Kits von Promega wurde die aus dem oben genannten Verfahren erhaltene Vektor-DNA nach einem Standardprotokoll an einer genau definierten Stelle mit Hilfe eines Restriktionsenzym geschnitten und linearisiert (gestreckt). Bevor diese Prozedur durchgeführt werden konnte, war es wichtig die Einbaurichtung des PCR-Produktes in das Plasmid zu kennen, da für „forward“ Einbau mit dem Enzym XhoI und für „reverse“ Einbau mit dem Enzym SpeI geschnitten werden muß.

Das Arbeiten mit in-situ-RNA-Sonden sieht eine „positive Sonde“ (antisense, Spiegelbild zur mRNA), welche die gewünschte mRNA detektiert, und eine ,negative Sonde" (sense), welche als Kontrolle dient und deckungsgleich mit der nachzuweisenden mRNA ist, vor. Daher ist es wichtig den Vektor für die Herstellung der jeweiligen Sonde mit dem richtigem Enzym zu schneiden. 
Für den Verdau wurden zu den $50 \mu 1$ Vektor $6 \mu 110$ x Reaktionspuffer und schließlich 4 $\mu 1 \mathrm{XhoI}$ oder SpeI zugegeben. Der Ansatz ist für 2 Stunden bei $37^{\circ} \mathrm{C}$ im Thermomixer (Eppendorf) inkubiert, zentrifugiert und mit $40 \mu$ l Ampuwa auf $100 \mu 1$ Gesamtvolumen aufgefüllt worden.

Die anschließende Aufreinigung erfolgte mit dem Wizard $^{\mathrm{TM}}$-DNA-Clean-Up-Kit (Promega). $\mathrm{Zu}$ den $100 \mu \mathrm{l}$ Ansatz wurde $1 \mathrm{ml}$ Wizard-Gelsuspension gegeben und vorsichtig gemischt. Die Lösung ist mit einer Spritze durch die Membran der WizardSäule gedrückt worden. Bei diesem Schritt bindet die DNA an die Säule. Nach einem Reinigungsschritt mit $2 \mathrm{ml} 80$ \%igem Isopropanol (J.T.Baker) wurde die Säule auf ein $1.5 \mathrm{ml}$ E-Cup gesetzt und bei $8000 \mathrm{~g}$ für 2 Minuten trocken zentrifugiert. Das E-Cup wurde verworfen und durch ein Neues ersetzt. Die DNA ist durch Zugabe von $50 \mu 170$ ${ }^{\circ} \mathrm{C}$ warmen Ampuwa und Zentrifugation bei $8000 \mathrm{~g}$ für 20 Sekunden aus der Säule eluiert worden. Der Durchlauf enthielt das gereinigte, linearisierte Plasmid. $1 \mu 1$ des Eluat ist zusammen mit einer Probe des unverdauten Vektors zur Überprüfung auf ein 1 \%iges Gel aufgetragen worden. Nach erfolgreicher Linearisierung erscheint in der Spur der linearisierten Probe nur noch eine Bande im Gel.

\subsubsection{Prinzip der in-situ-Hybridisierung mit dig/biotin-markierten RNA- Sonden}

Die Technik der in-situ-Hybridisierung ist eine spezielle Anwendung der durch Basenpaarung bewirkten Ausbildung eines doppelsträngigen Nucleinsäuremoleküls aus zwei getrennten Einzelsträngen, wobei die im Gewebe vorhandene DNA bzw. RNA die Matrix bildet, an der die Reaktion stattfindet. Bei der Hybridisierung von DNA muß die DNA vorher denaturiert werden, bei der RNA entfällt dieser Schritt.

Als mögliche in-situ-Sonden kommen DNA- oder RNA-Sonden in Frage. Das Arbeiten mit in-situ-Sonden sieht eine ,positive Sonde“ (antisense) und eine „,negative Sonde“ (sense) vor.

Die jeweilige Sonde kann, damit überhaupt ein Nachweis gelingt, mit unterschiedlichen Methoden und Stoffen markiert werden. Zum einen kann die RNA-Sonde z.B. am N7 der Purinbase mit einem Biotin-Platin-Komplex markiert werden und zum anderen können z.B. radioaktiv- oder Digoxigenin(dig)-markierte Basen beim Umschreiben der 
DNA zur RNA eingebaut werden. Es gibt auch die direkte Markierung mit FluoreszenzFarbstoffen.

Bei der verwendeten Methode wurden RNA Sequenzen im Gewebe (Paraffinschnitte) bei bestimmten Hybridisierungsbedingungen nachgewiesen. Die Hybridisierung wird von verschiedenen Faktoren beeinflußt, die Auswirkungen auf die Geschwindigkeit der Reaktion und die Spezifität haben. Die antisense Sonde lagert sich unter optimalen Reaktionsbedingungen (Hybridisierungstemperatur z.B. $65^{\circ} \mathrm{C}$ ) an die zu detektierende mRNA an. Die sense Sonde hingegen kann sich nicht anlagern, da ihr der Matritzenstrang fehlt. Hierbei ist die richtige Hybridisierungstemperatur für die Hybridisierung wichtig. Ähnlich wie bei der PCR lösen sich beim Erhitzen die Doppelstränge voneinander und gehen in Einzelstränge über. Wichtig ist dabei der sogenannte Tm-Wert (temperature of melting), der für einen definierten Doppelstrang die Temperatur angibt, bei der $50 \%$ der Doppelstränge als Einzelstränge vorliegen. Dieser Wert wird aber von verschiedenen Faktoren beeinflußt, wie z.B. die Länge der Nucleinsäure (je länger, desto fester Bindung, desto höher $T m$ ), deren Basenzusammensetzung (je mehr Purinbasen, desto höher Tm) und der Anteil falscher Basenpaarungen (je größer, desto niedriger Tm). Zudem haben aber auch die Salzkonzentration der Lösung und der Zusatz bestimmter Chemikalien (z.B. Formamid) Auswirkungen auf die Hybridisierungstemperatur (wirkt destabilisierend, senkt Tm). Für die meisten durchgeführten RNA-Hybridisierungen wird eine Temperatur zwischen 60 bis $68^{\circ} \mathrm{C}$ für $\sim 12$ bis 16 Stunden festgelegt.

Der Nachweis erfolgt dann entweder über einen Röntgenfilm (radioaktiv makierte Sonde), direkt im Fluoreszenz-Mikroskop (Fluoreszenz) oder über eine Antikörperreaktion (biotin- oder dig-makierte Sonde, Fluoreszenz). Der Antikörper, z.B. anti-dig-AP (Roche), an welchem eine alkalische Phosphatase gekoppelt ist, kann durch den Farbumschlag des Farbstoffkomplex z.B. NBT/BCIP (Roche) diese Bindung sichtbar machen.

Neben den positiven und negativen Sonden wurde eine weitere Kontrolle eingeführt: die Inkubation eines Schnittes nur mit Hybridisierungspuffer an Stelle mit einer Sonde. So konnten eventuelle unspezifische Bindungen ausgeschlossen werden.

In der vorliegenden Arbeit wurden zwei unterschiedliche Methoden zur in-situHybridisierung verwendet: zum einen die dig-makierte in-situ, zum andern über ein neues Verfahren, GenPoint (DakoCytomation), mit der biotin-makierten in-situ. 


\subsection{Dig-Markierung der RNA}

Während der in-vitro-Transkription wurde die DNA in RNA umgeschrieben und dabei gleichzeitig mit dig-UTP-Basen (digRNA-label-Mix) markiert, um so eine Detektion zu ermöglichen (Abb.6). Dig steht für Digoxigenin (aus der Digitalispflanze), einem Triterpen, welches nicht natürlich im Gewebe vorkommt und das sich daher zum spezifischen Nachweis eignet.

Je nachdem mit welchem Enzym die Linearisierung vorgenommen wurde, mußte die Polymerase ausgewählt werden. Wurde mit XhoI linearisiert, wurde für die Herstellung der Anti-Sense-Sonde die SP6-Polymerase benötigt, bei der Linearisierung mit SpeI die T7-Polymerase.

Für den Ansatz wurden $1 \mu \mathrm{l}(200 \mathrm{ng})$ gereinigter, linearisierter Vektor mit $8 \mu \mathrm{l}$ Velcorin-Wasser, $2 \mu 1$ digRNA-label-Mix (Roche), $4 \mu 1$ Transkriptionspuffer, $2 \mu 1100$ mM DDT, $1 \mu$ RNAseInhibitor und $2 \mu 1$ der jeweiligen Polymerase (T7 oder Sp6) gemischt und bei $37^{\circ} \mathrm{C}$ im Thermomixer für 2 Stunden inkubiert. Die vorhandene DNA ist durch Zugabe von 1 Unit RQ1-RNase-freie-DNAse pro $\mu \mathrm{g}$ eingesetzter DNA und einer Inkubation von 10 Minuten bei $37^{\circ} \mathrm{C}$ verdaut worden.

Anschließend wurden $2.5 \mu \mathrm{l} 4 \mathrm{M} \mathrm{LiCl}$ und $75 \mu 1100 \%$ eiskalter Ethanol zum Ansatz gemischt. Die Fällung der RNA erfolgte über Nacht bei $-20{ }^{\circ} \mathrm{C}$. Um ein RNA-Pellet zu erhalten ist der Ansatz 30 Minuten bei $4{ }^{\circ} \mathrm{C}$ und $10.000 \mathrm{~g}$ zentrifugiert worden. Der Überstand wurde dekantiert und das Pellet durch die Zugabe von $100 \mu 170 \%$ eiskaltem Ethanol gewaschen. Mit maximaler $\mathrm{g}$ ist der Ansatz für 15 Minuten zentrifugiert und anschließend der Überstand vorsichtig entfernt worden. Das Pellet wurde luftgetrocknet und in $22 \mu \mathrm{l}$ Velcorin-Wasser aufgenommen und sofort auf Eis gelagert. Eine Sondenüberprüfung erfolgte über das Auftragen der Sonden auf ein $1 \%$ iges Gel und durch eine Photometermessung einer 1:100 Verdünnung. Die Sonden wurden bei -70 ${ }^{\circ} \mathrm{C}$ gelagert.

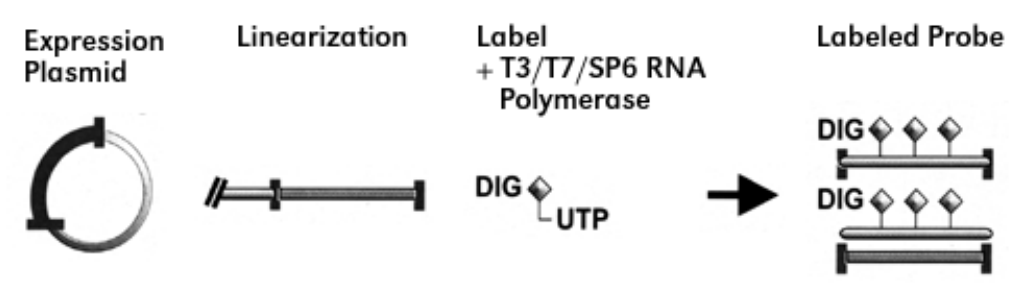

Abb.6: Prozedur zur Markierung der dig-Sonden (nach Roche-Katalog 2002) 


\subsection{Dig-in-situ-Hybridisierung (ISH)}

Für die ISH wurden alle 160 Schnitte (das entspricht einer Entfernung von $800 \mu \mathrm{m}$ ) je 9 Schnitte entweder mit dig- oder mit biotin-Sonden gefärbt (je 8 Sonden und eine Kontrolle).

Die in der ISH verwendeten Geräte, Lösungen und Reagenzien mußten steril und RNAse frei sein. Dazu wurden sie entweder gebacken (12 Stunden bei $240{ }^{\circ} \mathrm{C}$ ) oder autoklaviert (30 Minuten bei $120^{\circ} \mathrm{C}$ ). Stammlösungen wurden mit Velcorin-Wasser angesetzt und auch damit zu weiteren Arbeitslösungen verdünnt.

Im folgenden ist das Protokoll beschrieben, welches zur Hybridisierung benutzt wurden. Dieses Protokoll wurde in der Arbeitsgruppe in diversen Vorversuchen speziell auf die hier verwendeten Sonden abgestimmt.

Als eine negative Kontrolle wurde ein Schnitt nur mit Hybridisierungspuffer an Stelle einer Sonde behandelt.

Alle Inkubationen wurden, sofern nicht anders angegeben, bei Raumtemperatur durchgeführt.

am ersten Tag:

1. Entparaffinierung der Schnitte durch Xylol (2 x 5 Minuten)

2. Hydrierung durch Ethanol (100\%, $90 \%$ und $70 \%)$ für je 1 Minute

3. Umpufferung mit 1 x TBS (Tris/ $\mathrm{NaCl} 0.05 \mathrm{M}$, pH 7.6) für 2 x 5 Minuten (Schüttler)

4. Vorbereitung des Gewebes durch Zugabe von Proteinase K (DakoCytomation) direkt auf den Schnitt für 20 Sekunden

5. gründliches Waschen mit 1 x TBS für 2 x 5 Minuten (Schüttler)

6. Inkubation zur Blockierung der endogenen alkalischen Phosphatase mit $0.25 \%$ Essigsäureanhydrid in $0.1 \mathrm{M}$ Tris/ $\mathrm{HCl} \mathrm{pH} 8.0$ für 10 Minuten (Schüttler)

7. spülen in $1 \times$ TBS für $2 \times 5$ Minuten (Schüttler)

8. Dehydrierung durch Ethanol (70\%, $90 \%$ und $100 \%)$ für je 1 Minute

9. Lufttrocknung der Schnitte in der Hybridisierungskammer für 15 bis 20 Minuten

10. Inkubation einer 1:100 verdünnten Sonde (verdünnt mit mRNAHybridisierungspuffer, DakoCytomation) für 5 Minuten bei $55^{\circ} \mathrm{C}$ (Streckung der Sonden) im Thermomixer

11. Auftragung von $\sim 80 \mu \mathrm{l}$ Sonde pro Schnitt und Abdeckung mit einem sterilen Deckglas 
12. Inkubation für 5 Minuten bei $85^{\circ} \mathrm{C}$ auf der Heizplatte

13. Überführung der Schnitte in eine mit deonisiertes Formamid und Velcorin 1:2Lösung am Boden gefüllte Hybridisierungskammer, Abdichtung mit Klebeband und Hybridisierung über Nacht bei $65^{\circ} \mathrm{C}$

Am zweiten Tag folgte eine stringente Wäschen der Schnitte (Entfernung der ungebundenen Sonde) als einer der wichtigsten Schritte während der ISH, um unspezifische Bindungen und Hintergrundfärbungen zu vermeiden. Die Waschlösungen wurden aus 20x SSC $(\mathrm{NaCl}+\mathrm{Na}-\mathrm{Citrat}+$ Velc. Wasser, pH 7.0) mit Velc.-Wasser angesetzt.

14. zunächst wurde die Hybridisierungskammer auf Raumtemperatur abkühlt.

15. Die Deckgläschen sind durch Schwenken in Waschpuffer I ( 2 x SSC) abgelöst worden.

16. Anschließend wurde 20 Minuten im Waschpuffer I auf dem Schüttler gewaschen

17. und mit Waschpuffer II (1 x SSC) weitere 20 Minuten gründlich gespült (Schüttler).

18. Es folgte die Durchführung einer RNAseA-Behandlung mit einer auf $37{ }^{\circ} \mathrm{C}$ vorgewärmten RNAse-Lösung für 30 Minuten im Schüttelwasserbad bei $37^{\circ} \mathrm{C}$

19. und ein Waschen mit auf $37{ }^{\circ} \mathrm{C}$ vorgewärmten (zur Vermeidung eines Temperaturschocks) Waschpuffer III (0.5 x SSC) bei Raumtemperatur für 20 Minuten auf dem Schüttler.

20. Nach einer Inkubation für 20 Minuten mit Waschpuffer IV (Schüttler)

21. erfolgte dann erneut ein Waschen mit Waschpuffer IV diesmal bei $60{ }^{\circ} \mathrm{C}$ im Schüttelwasserbad.

22. Danach wurden die Schnitte mit neuem auf $60^{\circ} \mathrm{C}$ vorgewärmtem Waschpuffer IV bei Raumtemperatur auf dem Schüttler herunterkühlt

23. und zu Abschluß der Waschvorgänge mit Maleinsäurepuffer für 15 Minuten gespült und umgepuffert (Schüttler).

24. Nach einer Inkubation für 15 Minuten mit Blockingreagenz (Blockingstammlösung und FCS gelöst in TBST) zur Blockierung unspezifischer Antikörperbindungen

25. wurden $80 \mu \mathrm{l} /$ Schnitt des gegen Digoxigenin gerichteten Antikörperansatzes (5 $\mu 110$ FCS, $50 \mu 1$ Blockingstammlösung, $444 \mu 1$ TBST und $1 \mu 1$ anti-dig) aufgebracht und für 2 Stunden in einer feuchten (Velcorin-Wasser) Kammer inkubiert 
26. Anschließend erfolgte ein 3 x 5 minütiges Spülen mit Maleinsäurepuffer zur Entfernung der nicht gebundenen Antikörper.

27. Mit einer Pufferlösung Tris/ $\mathrm{NaCl} 0.1 \mathrm{M}$ pH 9.5 wurde eine 2 x 5 Minuten Umpufferung vorgenommen.

28. Es folgte eine Auftragung von $\sim 80 \mu \mathrm{l}$ des Chromogenansatzes (auf $1 \mathrm{ml}$ Tris/NaCl 0.1 M pH 9.5 wurden $4.5 \mu$ Nitroblautetrazoliumchlorid (NBT) und $3.5 \mu 1$ Bromchorindolphosphat (BCIP) gegeben) auf den Schnitt und eine Lagerung in einer feuchten Kammer (Velcorin-Wasser) bis zum vollständigen Farbumsatz. Die Farbreaktion wurde mit Velcorin-Wasser gestoppt.

Je nachdem, ob eine Doppelfärbung vorgesehen war, wurden die Schnitte:

* mit Kernechtrot für 1 Minute gegengefärbt und nach Dehydratation über die Ethanolreihe (70\%, $90 \%$ und $100 \%$ ) für je 1 Minute für 2 x 5 Minuten in Xylol überführt. Abschließend erfolgte die Eindeckung mit DePeX und Deckgläschen.

* in die immunhistologische Färbung (Start im jeweiligen Protokoll mit der Umpufferung für die Blockierungsreaktion) überführt.

Positive ISH-Reaktionen färbten blau, Kerne durch die Gegenfärbung rot.

\subsection{Biotin-Markierung der RNA}

Bei diesem Verfahren der Markierung wird, anders als bei der Digoxigenin-Markierung, zuerst eine in-vitro-Transkription mit dem RiboMax-Kit (Promega) durchgeführt und anschließend folgt die RNA-Markierung. Die Ansätze wurden wie folgt pipettiert:

Für die Sp6-Polymerase wurden zu den $50 \mu$ l linearisiertem Vektor $20 \mu 15$ x Sp6 Transkriptionspuffer, $20 \mu 1$ NTP-Mix (aus 100 mM NTP) sowie $10 \mu 1$ Sp6-Polymerase gegeben.

Der Ansatz für die T7-Polymerase setzte sich aus $50 \mu 1$ linearisiertem Vektor, $23 \mu 15 \mathrm{x}$ T7 Transkriptionspuffer, $30 \mu 1$ NTP-Mix, $0.5 \mu$ Velcorin-Wasser und schließlich 11.5 $\mu 1$ T7-Polymerase zusammen.

Die Ansätze wurden gemischt und für 4 Stunden bei $37{ }^{\circ} \mathrm{C}$ im Thermomixer inkubiert. Die DNA wurde mit 1 Unit RQ-RNAse-freie-DNAse pro $\mu$ g eingesetzter DNA in einer Inkubationdauer von 15 Minuten bei $37^{\circ} \mathrm{C}$ verdaut.

Die Aufarbeitung erfolgte mit dem RNeasy-Kit ${ }^{\circledR}$ (ähnlich der unter 2.4.1 beschriebenen Aufarbeitung). Die Ansätze wurden wie folgt pipettiert: 
Für den Sp6-Polymerase-Ansatz wurden die $110 \mu 1$ Ansatz mit $385 \mu 1$ RLT-Puffer und $275 \mu 1100$ \%igem Ethanol gemischt, für den T7-Polymerase-Ansatz die $125 \mu \mathrm{l}$ mit $473.5 \mu 1$ RLT-Puffer und $312.5 \mu 1100 \%$ igem Ethanol.

Anschließend sind die Ansätze auf die RNeasy-Säulen gegeben und für 15 Sekunden bei 10.000 g zentrifugiert worden. Die Säulchen wurden auf ein neues Sammelgefäß gesetzt und anschließend zweimal mit je $500 \mu \mathrm{l}$ RPE-Puffer gewaschen. Beim ersten Waschgang wurden die Säulen für 15 Sekunden bei $10.000 \mathrm{~g}$ zentrifugiert, beim zweiten Durchgang wurden sie bei maximaler Drehzahl für 2 Minuten getrocknet.

Die Eluierung der RNA in neue E-Cups erfolgte durch 2 x $50 \mu$ Z Zugabe von RNAsefreiem Wasser auf die Säulen und einer Zentrifugationsdauer von je 1 Minute bei 10.000 g. Der Durchlauf ist sofort auf Eis gestellt und von den $100 \mu 1$ RNA-Eluat sind sofort $8 \mu 1$ in $72 \mu 1$ RNAse-freies-Wasser gegeben worden. Diese 1:10 Verdünnung wurde am Photometer gemessen. Das RNA-Eluat wurde dann bei $-70^{\circ} \mathrm{C}$ eingefroren.

Die RNA-Markierung wurde mit einem ULS ${ }^{\circledR}$-Labeling-Kit (Universal Link $\underline{\text { System) }}$ ULYSIS $^{\circledR}$ (Kreatech) durchgeführt.

Die ULS-Methode, eine schnelle und hoch sensitive Makierungsmöglichkeit (Van Eijsden et al. 1996) nutzt die Affinität einer Platin(Pt)-Verbindung zu den heterocyclischen Stickstoffen in den Nucleotidbasen. Dieser quadratisch planare Pt(II)Komplex weist zwei freie Bindungsstellen auf. An die eine ist das Biotin gebunden $\left(\right.$ BIO-ULS ${ }^{\circledR}$ ) und die andere bindet stabil an die N7(Stickstoff)-Position in Purinbasen (z.B. Guanin).

Für die Makierung mit diesem Kit wurden $1 \mu \mathrm{g}$ RNA eingesetzt. Das Volumen ist mit Labeling-Lösung auf $20 \mu 1$ aufgefüllt worden. Zu diesem Ansatz wurden $1 \mu 1$ (1U) BIOULS (pro $1 \mu \mathrm{g}$ RNA $1 \mu$ BIO-ULS) zugegeben. Die Reaktion erfolgte in nur 30 Minuten bei $85{ }^{\circ} \mathrm{C}$. Der Ansatz wurde kurz zentrifugiert, dann mit $5 \mu$ l Stoplösung vermischt und für 10 Minuten bei Raumtemperatur inkubiert.

Die markierten Sonden wurden bei $-70{ }^{\circ} \mathrm{C}$ eingefroren.

\subsection{Biotin-in-situ-Hybridisierung mit GenPoint}

Bei dem DAKO GenPoint ${ }^{\mathrm{TM}}$ System (DakoCytomation) handelt es sich um ein neues Signalamplifikations-System der in-situ-Hybridisierung. Das System arbeitet mit biotinmarkierten Sonden. Basierend auf der Catalyzed Signal Amplification-Technologie 
(Tyramid-Signalverstärkung) können sogar Single-Copy-Zielsequenzen schnell und einfach nachgewiesen werden (nach Methodenblatt GenPoint, DakoCytomation). Das dabei verwendete Streptavidin ist ein kleines Protein, welches vier Bindungsstellen für Biotin besitzt, von denen aber nur zwei besetzt werden. Das Streptavidin bildet mit einem biotinylierten Enzym, hier HRP, einen großen dreidimensionalen Komplex und bindet als primärer Streptavidin-HRP-Komplex über freie Bindungsstellen des Streptavidin an den Biotin-Platin-Komplex, der seinerseits an die gebundene Sonde gelabelt ist. Biotinyl-Tyramide Komplexe lagern sich in einem weiteren Schritt um den gebundenen Streptavidin-Komplex. Schließlich wird der sekundäre Streptavidin-HRPKomplex zugegeben, der an das Biotin des Biotinyl-Tryamide-Komplex bindet und so die Signalverstärkung komplettiert (Abb.7). Durch Zugabe eines chromogenen Substrates (Diaminobenzidin Plus, DAB+) wird das Signal sichtbar gemacht.

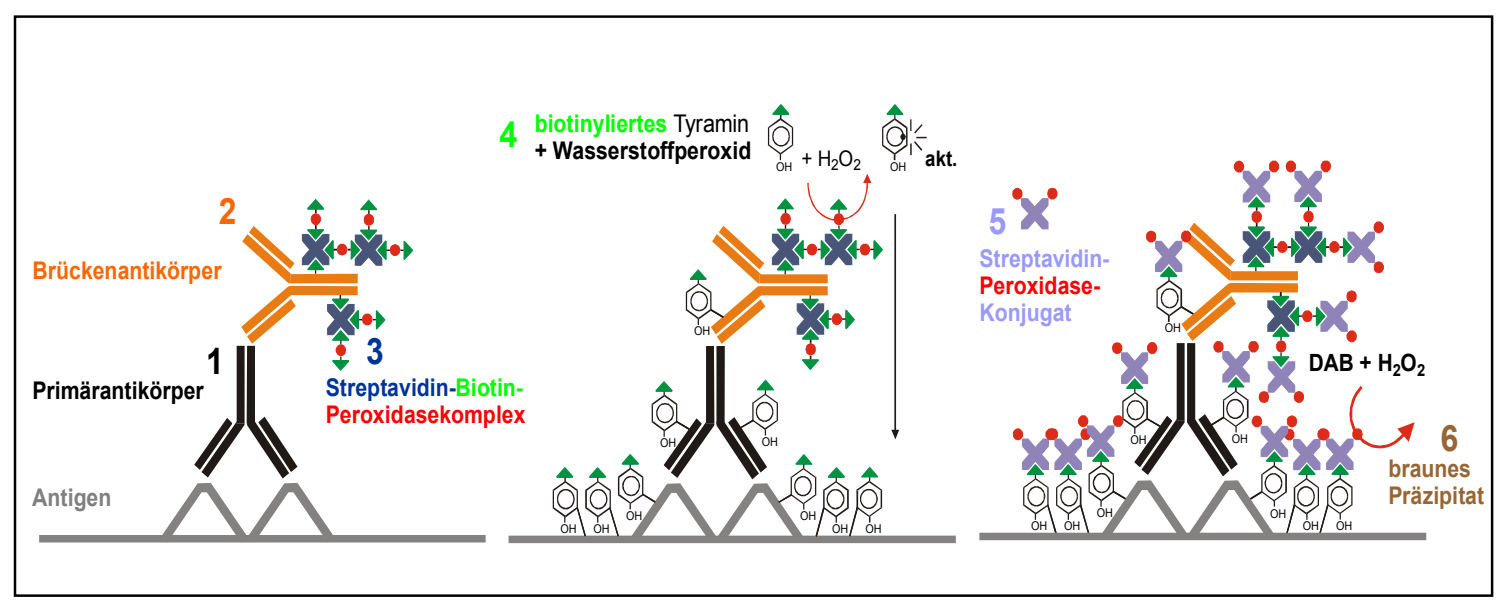

Abb.7: Prinzip der GenPoint Reaktion (nach Methodenblatt GenPoint, DakoCytomation)

Für die ISH wurden alle 160 Schnitte (das entspricht einem Schritt von $800 \mu \mathrm{m}$ ) entweder mit dig- oder mit biotin-Sonden 9 Schnitte gefärbt (je 8 Sonden und eine Kontrolle).

Für die Durchführung dieser ISH gelten dieselben sterilen und RNAse-freien Bedingungen, wie für die dig-ISH. Auch hier wurde als negative Kontrolle ein Schnitt nur mit Hybridisierungspuffer an Stelle der Sonde inkubiert.

Folgendes Protokoll wurde durchgeführt:

1. Entparaffinierung der Schnitte durch Xylol (2 x 5 Minuten)

2. Hydrierung durch Ethanol (100\% 2 x 1 Minute, $90 \% 3 \times 1$ Minute) und Wasser ( $3 \times 1$ Minute)

3. sowie der Aufbrechung der Paraformaldehydbindungen über dem Gewebe durch Inkubation mit Target Retrieval Solution für 20 Minuten bei $95{ }^{\circ} \mathrm{C}$, einer 
Abkühlphase von 20 Minuten und Proteinase K (gebrauchsfertig) für 20 Sekunden bei Raumtemperatur

4. und der Reduzierung des Hintergrundes mittels Wasserstoffperoxid-MethanolLösung $\left(0.3 \% \mathrm{H}_{2} \mathrm{O}_{2}\right)$ und 10 Minuten spülen in Velcorin-Wasser

Danach wurden:

5. die Biotin-Sonden in einer 1:100 bzw. 1:50 Verdünnung auf den Schnitt aufgebracht, mit sterilen Deckgläschen bedeckt und bei $37^{\circ} \mathrm{C}$ in einer feuchten Kammer (Velcorin-Wasser) für 60 Minuten inkubiert.

6. Nach vorsichtigem Ablösen der Deckgläschen in $1 \mathrm{x}$ TBST erfolgte die stringente Waschung der Schnitte mit der vorgewärmten Waschlösung für 20 Minuten bei $55^{\circ} \mathrm{C}$.

7. Danach wurde mit dem ersten Streptavidin-HRP (horse-radish-peroxidase)Komplex eine 15 Minuten dauernde Inkubation bei Raumtemperatur durchgeführt.

8. Alle nachfolgenden Schritte wurden ebenfalls bei Raumtemperatur durchgeführt.

9. Die nicht gebundenen Komplexe wurden durch 3 x 5 Minuten spülen auf dem Schüttler mit 1 x TBST entfernt.

10. Nun wurde mit der Biotinyl-Tyramide Lösung eine Signalamplifikation durchgeführt.

11. Die überschüssige, nicht gebundene Lösung wurde durch 3 x 5 Minuten waschen mit 1x TBST auf dem Schüttler abgespült.

12. Mit dem folgenden Schritt, der Inkubation mit dem zweiten Streptavidin-HRPKomplex, für 15 Minuten ist die Signalverstärkung beendet worden.

13. Im Anschluß an den nötigen Waschschritt mit 1x TBST auf dem Schüttler für je 3 x 5 Minuten wurde

14. die $\mathrm{DAB}+\mathrm{Chromogen-Reaktion} \mathrm{ausgelöst} \mathrm{(1:50} \mathrm{Verdünnung} \mathrm{des} \mathrm{DAB}+$ mit dem im Kit vorhandenen Verdünnungsmedium). Die im Kit enthaltenden positiven Kontrollen und Sonden reagierten bereits nach wenigen Sekunden und färbten sich braun.

15. Die Farbreaktion wurde mit bi-destilliertem Wasser gestoppt.

Je nachdem, ob eine Doppelfärbung vorgesehen war, wurden die Schnitte:

* mit Hämatoxilin (blau) gegengefärbt und nach Dehydratation über die übliche Ethanol-Xylol-Reihe und mit DePeX eingedeckt, 
* oder in die immunhistologische Färbung (Start im jeweiligen Protokoll mit der Umpufferung für die Blockierungsreaktion) überführt.

Positive ISH-Reaktionen waren braun, Kerne durch die Gegenfärbung blau.

\subsection{Nachweis der Sondenspezifität durch Northern Blots}

Parallel zu den ISH wurden zur Überprüfung der Sondenspezifität sogenannte Northern Blots durchgeführt. Bei diesem Verfahren werden nach der Auftrennung einer totalRNA-Probe mittels Elektrophorese die RNA-Bande aus einem denaturierendem Gel (meist Formaldehydgel) auf einen Nylon oder Cellulosemembran übertragen. Dies geschieht über den sogenannten Blotaufbau, bei dem über Kapillarkräfte die RNABanden aus dem Gel gezogen und auf eine Membran übertragen werden. Die Fixierung auf der Membran erfolgt über UV-Crosslink oder Backen. Anschließend wird mit der Membran, genau wie mit den Schnitten, eine Hybridisierung durchgeführt. So läßt sich anhand des Bandenmusters feststellen, ob die Sonde, die in der totalen-mRNA enthaltene Zielsequenz spezifisch erkennt, oder nicht.

Als Ausgangs-RNA wurden Proben der, wie unter Punkt 2.5.2.2 beschrieben isolierten, total-Hypothalamus-RNA durch das Gel aufgetrennt. Bei dieser Nachweismethode wurden sowohl die positiven (zeigen eine Reaktion auf der Membran), als auch die negativen Sonden (sollten keine Reaktion auf der Membran zeigen) getestet. Als eine positive Kontrolle wurde, nach dem unter Punkt 2.5.2.1 beschriebenen Methode isolierte, mRNA der Milz neben der Hypothalamus-mRNA auf das Trenngel aufgetragen, da die Milz, als blutbildendes Organ, reich an IL-1 $\beta$-mRNA ist.

Für das Arbeiten gelten auch hier die selben Bedingungen, wie bei den ISH (steril und RNAse-frei)

Nach einem Protokoll im Dig Application Manual for Filter Hybridization (Roche) wurde zunächst ein Trenngel angefertigt. Dazu wurde:

1. ein $1.5 \%$ ige Agarosegel (in 1 x MOPS-Puffer mit $2 \%$ Formaldehyd) in eine 16Taschen-Gelkammer gegossen und mit 1 x MOPS (3-[N-Morpholino]propanesulfonicacid) als Laufpuffer bedeckt.

2. Die Proben $(1 \mu \mathrm{g})$ wurden 1:2 mit RNA-Ladungspuffer gemischt und nach einer

3. Denaturierung bei $65^{\circ} \mathrm{C}$ für 10 Minuten und

4. Schockkühlung auf Eis 
5. auf das Gel aufgetragen und bei 110 Volt in 1-2 Stunden aufgetrennt.

6. Die Färbung des Gels erfolgte für 20 Minuten mit einem Ethydium-Bromid-Bad. Der Aufbau des Blots sah wie folgt aus:

In zwei Schalen, über die eine Glasplatte gelegt war, wurde 20 x SSC-Puffer gefüllt. Ein 3M Whatman-Paper Streifen ist in $20 \mathrm{x}$ SSC-Puffer getränkt und über die Glasplatte gelegt worden. Dabei war zu beachten, daß die Enden in den beiden Pufferbehältern hingen, damit der Whatman-Streifen nicht trocken fielen. Auf dem Whatman-Papier lag das Gel auf. Über das Gel wurde eine positiv geladene Nylonmembran und darüber mindestens zehn Lagen 3M Whatman-Papier gelegt. Um eine Saugwirkung auf die Flüssigkeit und die RNA im Gel auszuüben sind darüber $\sim 10 \mathrm{~cm}$ Papiertücher gestapelt worden. Zur Stabilität und um ausreichend Druck auszuüben ist oben ein Gewicht von 1 kg aufgebracht worden. Der Transfer der RNA aufgrund der Diffusionkräfte erfolgte über Nacht. Nach Trocknung der Membran mußte eine Fixierung der RNA auf der Membran mittels UV-Crosslink (90 Sekunden) vorgenommen werden.

Die Hybridisierung des Blots wurde am ersten Tag wie folgt durchgeführt:

1. Prehybridisierung der Membran in einem sterilen 50ml Falcon-Tube (Sarsted) mit $20 \mathrm{ml}$ DIG Easy Hyb-Lösung (Roche) im Schüttelwasserbad bei $68{ }^{\circ} \mathrm{C}$ für 30 Minuten.

2. $50 \mathrm{ng} / \mathrm{ml} \mathrm{dig-Sonde} \mathrm{(Verdünnung} \mathrm{in} \mathrm{Hybridisierungspuffer)} \mathrm{für} 5$ Minuten im Thermomixer bei $95^{\circ} \mathrm{C}$ denaturieren und

3. sofort auf Eis schockkühlen.

4. Die Sonde mit $10 \mu 1$ auf $65^{\circ} \mathrm{C}$ vorgewärmter DIG Easy Hyb-Lösung mischen,

5. nach Abgießen der Prehybridisierungslösung in das Tube geben und über Nacht (für 12 bis 16 Stunden) im Schüttelwasserbad bei $65^{\circ} \mathrm{C}$ unter sanfter Bewegung inkubieren.

am zweiten Tag:

Alle Inkubationen fanden, soweit nicht anders angegeben, bei Raumtemperatur statt. Es wurde zur Detektion das DIG Nucleic Acid Detection Kit (Roche) wie folgt verwendet:

6. Abgießen der Lösung und Waschen der Membran mit $\sim 30 \mathrm{ml} 2$ x SSC-Puffer (mit $0.1 \%$ SDS, Low Stringency Buffer) in einer RNase-freien Plastikschale für 2 x 10 Minuten

7. Inkubation der Membran in einem Tube mit $\sim 25 \mathrm{ml}$ auf $68^{\circ} \mathrm{C}$ vorgewärmten 0.1 x SSC-Puffer (mit 0.1\% SDS, High Stringency Buffer) für 2 x 15 Minuten im Schüttelwasserbad 
8. Spülen der Membran in $30 \mathrm{ml}$ Maleinsäurepuffer in der Plastikschale

9. 30 Minuten Inkubation mit $30 \mathrm{ml}$ Blockierungslösung auf dem Schüttler

10. Inkubation mit $20 \mathrm{ml}$ Antikörperlösung für 30 Minuten

11. Waschen der Membran für 2 x15 Minuten auf dem Schüttler

12. 5 Minuten Äquilibrierung durch $20 \mathrm{ml}$ Detektionspuffer

13. Inkubation mit $10 \mathrm{ml}$ der Farbsubstratlösung (NBT/BCIP) für $\sim 1$ bis 2 Stunden

14. Stoppen der Farbreaktion durch Überführung der Membran in aqua bidest $_{1}$

\subsubsection{Immunhistologische Nachweismethoden (IHC)}

Das Prinzip der IHC beruht auf der spezifischen Erkennung von Antigenen in Geweben, Schnitten oder Zellen durch Antikörper und der anschließenden Verstärkung des Signals durch Brückenantikörper. Das Antigen wird so schließlich durch eine Farbreaktion sichtbar gemacht.

Wichtig ist hierbei immer die Behandlung der Gewebe, d.h. das die Bindungsstellen, an die der Antikörper binden soll nicht von z.B. der Formalinfixierung zerstört (zu lange fixiert) oder maskiert sind. Durch gewisse Vorbehandlungen (wie auch bei der ISH) können diese Störungen beseitigt werden (Antigen-Demaskierung). Dafür gibt es verschiedene Methoden, wie z.B. proteolytischen Verdau mit Trypsin (oder Proteinase K bei der ISH), Kochen der Schnitte oder Erhitzen mit sogenannten TUF's (target unmasking fluid) wie z.B. Target Retrieval Solution (DakoCytomation).

Nach der erforderlichen Blockierung z.B. der alkalische Phosphatase oder endogener Peroxidase wird der primäre Antikörper verdünnt oder als gebrauchsfertige Lösung auf den Schnitt gegeben. Meist werden dazu aufgrund ihrer höheren Spezifität monoklonale Antikörper verwendet.

Nach den klassischen IHC-Methoden wird, nachdem der primäre Antikörper an das Antigen gebunden hat, dieser mit einem Sekundärantikörper, der gegen Immunglobuline derjenigen Spezies, in welcher der erste Antikörper produziert wurde, von Mäusen oder Kaninchen gerichtet ist, markiert. An den Sekundärantikörper werden Stoffe (Enzyme) gekoppelt, die eine Farbreaktion ermöglichen. Dabei gibt es die enzymatischen Methoden (z.B. Avidin-Biotin-Komplex oder alkalische Phosphataseanit-alkalische Phosphatase) oder die Fluoreszenz-Methode. 
Die Farbreaktionen werden mit löslichen Substraten z.B. DAB ausgelöst, die durch das Enzym in einen unlöslichen Farbstoff überführt werden.

\subsubsection{Antikörper}

Zur Untersuchung der Verteilung von IL-1 $\beta$ (SantaCruz und R\&DSystems),sowie von IL-1ra, IL-1RI und IL-1RII (alle drei R\&DSystems) wurden die in Tabelle 4 aufgeführten humanen Antikörper bestellt, da es keine spezifischen Antikörper für $C$. jacchus bzw. Affen gab. Die lyophilisierten Antikörper der Firma R\&DSystems wurden nach Herstellerangaben in $1 \mathrm{ml} 1 \mathrm{x}$ PBS gelöst und in entsprechenden Aliquots bei -70 ${ }^{\circ} \mathrm{C}$ eingefroren, um so eine Möglichst hohe Stabilität der Antikörper zu erreichen. Der Antikörper der Firma SantaCruz war bereits gelöst und konnte bei $4^{\circ} \mathrm{C}$ im Kühlschrank gelagert werden. Die zu benötigte Konzentration der Antikörper wurden in Vorversuchen getestet (Tab.5). Zur Verdünnung wurde ein hintergrundreduzierendes Antikörperverdünnungsmedium (DakoCytomation) verwendet.

Um eine mögliche Zelltypzuordnung vornehmen zu können, wurden gebrauchsfertige bzw. verdünnte Antikörper gegen Neuron-Spezifische-Enolase (NSE) und GliaFibrillary-Acidic-Protein (GFAP) der Firma DakoCytomation verwendet. Diese Antikörper waren gelöst und wurden bei $4{ }^{\circ} \mathrm{C}$ gelagert.

Als negative Kontrolle wurden mit jeder IH ein Schnitt nur mit Antikörperverdünnungsmedium anstelle des Primärantikörpers inkubiert.

Tab.5: Liste der verwendeten Antikörper

\begin{tabular}{|c|c|c|c|}
\hline Antikörper & Hersteller & Anfangskonzentration & Verdünnung \\
\hline polyclonal-rabbit-anti-human-IL-1 $\beta$ & SantaCruz & $200 \mu \mathrm{g} / \mathrm{ml}$ & $20 \mu \mathrm{g} / \mathrm{ml}$ \\
\hline monoclonal-mouse-anti-human-IL-1 $\beta$ & R\&DSystems & $500 \mu \mathrm{g} / \mathrm{ml}$ & $25 \mu \mathrm{g} / \mathrm{ml}$ \\
\hline monoclonal-mouse-anti-human-IL-1 ra & R\&DSystems & $1 \mathrm{mg} / \mathrm{ml}$ & $25 \mu \mathrm{g} / \mathrm{ml}$ \\
\hline monoclonal-mouse-anti-human-IL-1RI & R\&DSystems & $500 \mu \mathrm{g} / \mathrm{ml}$ & $50 \mu \mathrm{g} / \mathrm{ml}$ \\
\hline monoclonal-mouse-anti-human-IL-1RII & R\&DSystems & $500 \mu \mathrm{g} / \mathrm{ml}$ & $25 \mu \mathrm{g} / \mathrm{ml}$ \\
\hline monoclonal-mouse-anti-human-NSE & DakoCytomation & gebrauchsfertig & $50 \mu \mathrm{g} / \mathrm{ml}$ \\
\hline monoclonal-mouse-anti-human-NSE & DakoCytomation & $450 \mu \mathrm{g} / \mathrm{ml}$ & $22.5 \mu \mathrm{g} / \mathrm{ml}$ \\
\hline monoclonal-mouse-anti-human-GFAP & DakoCytomation & $130 \mu \mathrm{g} / \mathrm{ml}$ & $26 \mu \mathrm{g} / \mathrm{ml}$ \\
\hline polyclonal-rabbit-anti-cow-GFAP & DakoCytomation & gebrauchsfertig & $\mu \mathrm{g} / \mathrm{ml}$ \\
\hline
\end{tabular}




\subsubsection{DAKO EnVision ${ }^{\mathrm{TM}}+$ und DAKO ChemMate $^{\mathrm{TM}}$ EnVision $^{\mathrm{TM}}+$}

Bei der in der Arbeit verwendeten Methode der IHC wurde eine neue Entwicklung der Firma DakoCytomation verwendet. Das sogenannte DAKO EnVision ${ }^{\mathrm{TM}}$-System.

Im Gegensatz zur herkömmlichen 3-Schritt-Methode (primärer Ak, Brücken-Ak, sekundärer Ak) werden nur zwei Schritte durchgeführt (primärer Ak, DAKO

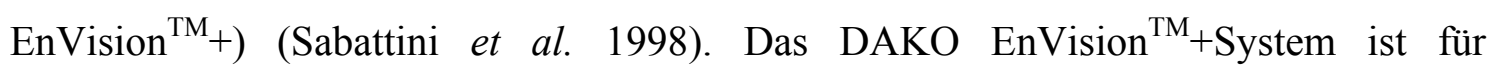
Primärantikörper (mono- oder polyclonal) aus Maus/Ratte und Kaninchen zu verwenden und besteht aus Polymereketten, an denen die Sekundärantikörper und Enzymmoleküle (HRP oder AP) gekoppelt sind (Abb.8). Das System wird als gebrauchsfertige Lösung angeboten und braucht nur auf den Schnitt aufgetropft werden. Diese Methode ist sensitiver als die 3-Schritt-Methode und zeitsparend.

Das DAKO ChemMate ${ }^{\mathrm{TM}}$ EnVision ${ }^{\mathrm{TM}}+$ System wurde speziell für die automatisierte Färbung hergestellt und unterscheidet sich aber in der Länge der Polymereketten. Dadurch regiert es sensitiver als das für eine Färbung ohne Maschine verwendete EnVision $^{\mathrm{TM}_{+}}$. Wird es für eine manuell durchgeführte Färbung verwendet, so muß sowohl die Inkubationszeit des Primärantikörpers, als auch die mit dem ChemMate $^{\mathrm{TM}}$ EnVision ${ }^{\mathrm{TM}}+$ System um die Hälfte reduziert werden.

Die Farbreaktion kann mit DAB (braun), AEC (rot) oder Fast Red (rot) vorgenommen werden. Das im kommerziell angebotenen EnVision ${ }^{\mathrm{TM}}+$ Kit vorhandene $\mathrm{DAB}+$ zeichnet sich durch eine noch höhere Sensitivität gegenüber den zuvor genannten Substraten aus.

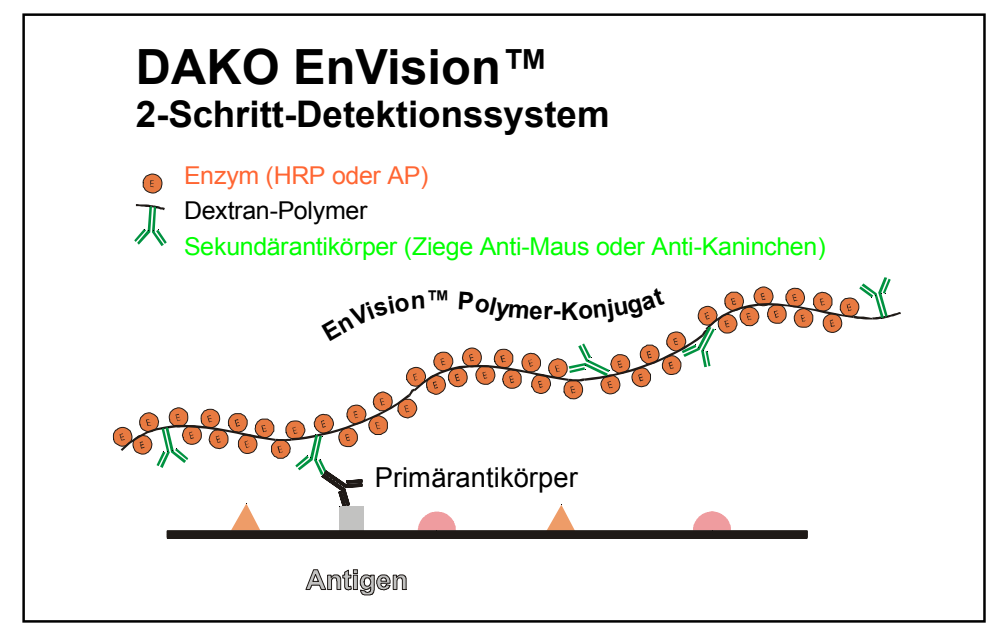

Abb.8: EnVision System (nach Methodenblatt EnVision, DakoCytomation) 
Für die IHC wurden alle 160 Schnitte (also im Abstand von $800 \mu \mathrm{m}$ ) 8 Schnitte entweder mit dem TechMateTMHorizon (ChemMateTMEnVisionTM+System), oder aber manuell (EnVisionTM+) gefärbt (je 6 Antikörper +2 Kontrolle).

Doppelfärbungen wurden generell manuell gefärbt.

\subsection{DAKO EnVision ${ }^{\mathrm{TM}}+$}

Die IHC wurde bei Raumtemperatur, soweit nicht anders angegeben, nach folgendem Protokoll durchgeführt:

1. Entparaffinierung der Schnitte erfolgte durch Xylol ( 2 x 5 Minuten),

2. Hydrierung durch Ethanol (100\%, $90 \%$ und $70 \%)$ für je 1 Minute,

3. kurzes Eintauchen in aqua $a_{\text {bidest }}$

4. und Umpufferung mit 1 x TBS für 3 x 5 Minuten (Schüttler),

5. Vorbereitung des Gewebes durch eine Trypsinbehandlung für 10 Minuten bei 37 ${ }^{\circ} \mathrm{C}$ durch Pipettieren direkt auf den Schnitt und

6. gründliches Waschen mit 1 x TBS für 3 x 5 Minuten (Schüttler).

7. Nach kurzem Eintauchen in aqua ${ }_{\text {bidest }}$ erfolgte

8. die Inkubation zur Blockierung der endogenen Peroxidase mit der gebrauchsfertigen Peroxidaseblockierungsreagenz (DakoCytomation) für 10 Minuten direkt auf dem Schnitt.

9. Nach erneutem Spülen in 1 x TBS für 10 Minuten (Schüttler) wurden

10. $\sim 80 \mu \mathrm{l}$ (in der jeweiligen Verdünnung, Tab.4) der Primärantikörper (oder ein Tropfen bei gebrauchsfertigen) direkt auf den Schnitt pipettiert und für 30 Minuten inkubiert.

11. Mit $1 \times$ TBS wurden die Schnitte 3 x 5 Minuten lang gewaschen und

12. anschließend für 30 Minuten die EnVision ${ }^{\mathrm{TM}}$-Lösung aufgetropft.

13. Für 3 x 5 Minuten wurde mit 1x TBS gespült und

14. kurz in aqua ${ }_{\text {bidest }}$ gespült.

15. Mit DAB+-Chromogen ist die Farbreaktion innerhalb von 10 Minuten nach direkter Aufbringung auf den Schnitt ausgelöst worden.

16. Die Schnitte wurden kurz in aqua $a_{\text {bidest }}$ gespült und

17. mit Hämatoxilin (DakoCytomation) für 2 Minuten gegengefärbt (Auslösung des Farbumschlages durch Inkubation unter fließendem Wasser für 10 Minuten). 
18. Die Dehydratation erfolgte über die Ethanolreihe (70\%, $90 \%$ und $100 \%)$ für je $2 \times 1$ bis 2 Minuten und

19. für 2 x 10 Minuten in Xylol.

20. Die Schnitte wurden mit DePeX eingedeckt.

Positive IHC-Signale waren braun, Kerne durch die Gegenfärbung blau.

\subsection{DAKO ChemMate ${ }^{\mathrm{TM}}$ EnVision $^{\mathrm{TM}}+$}

Bei einen großen Teil der IHC-Färbungen wurde der bereits unter Punkt 2.5.1.1 erklärte TechMate ${ }^{\mathrm{TM}}$ Horizon Immunfärbe-Automat verwendet. Es ist das in Tabelle 6 im Anhang aufgeführte Protokoll verwendet worden.

Es wurden spezielle ChemMate ${ }^{\mathrm{TM}}$-Reagenzien der Firma DakoCytomation für den TechMateHorizon verwendet:

$>$ Saugkissen (Wattepads) für TechMate 500

$>$ Reagenziengefäße für TechMate ${ }^{\mathrm{TM}}$ Färbeautomaten

$>$ Dako ChemMate ${ }^{\mathrm{TM}}$ Pufferkit (gebrauchsfertig, 4 x $500 \mathrm{ml}$ )

$>$ Dako ChemMate ${ }^{\mathrm{TM}}$ Antikörperverdünnungsmedium (gebrauchsfertig)

> Dako ChemMate ${ }^{\mathrm{TM}}$ Peroxidase-Blockierungs-Lösung (gebrauchsfertig, 3 \%ig)

$>$ Dako ChemMate ${ }^{\mathrm{TM}}$ EnVision $^{\mathrm{TM}}$ Detektion Kit Peroxidase/DAB Kaninchen/Maus (enthält gebrauchsfertig EnVision, Chromogenpuffer und Chromogen: auf $8 \mathrm{ml}$ Puffer $160 \mu$ l Chromogen)

$>$ Dako ChemMate ${ }^{\mathrm{TM}}$ Hämatoxilin (gebrauchsfertig)

Die Antikörperverdünnung entsprach derselben Konzentration, wie für die manuelle Färbung.

Aufgrund der unterschiedlichen Reagenzien im Vergleich zur Handfärbung wurden andere Inkubationszeiten mit den speziell für den TechMate ${ }^{\mathrm{TM}}$ hergestellten Lösungen, gewählt.

\subsubsection{Doppelfärbungen (ISH/IHC)}

Mit einer Doppelfärbung ist es möglich, mehrere „Ziele“ auf einem Schnitt nachzuweisen. 
Zur Klärung, welcher Zelltyp (Neuron oder Glia) den nachzuweisenden Stoff expremiert wurde erst eine ISH mit dig-Sonden durchgeführt. Anschließend wurden die Schnitte nach einer Umpufferung mit $1 \mathrm{x}$ TBS sofort in die IHC überführt. Das Protokoll der IHC wurde mit dem Blockieren der endogenen Peroxidase begonnen und wie oben beschrieben fortgeführt. Auf eine Gegenfärbung wurde verzichtet.

Insgesamt wurden für jede der 8 Sonden 8 Doppelfärbungen ( 2 x GFAP und 2 x NSE) durchgeführt. Eine Kontrolle der ISH wurde auch als Kontrolle der IHC mitgeführt. Zur Antikörperkontrolle sind je 3 Schnitte nur mit GFAP oder NSE gefärbt worden.

\subsubsection{Auswertung der Färbungen}

Die so gefärbten Schnitte wurden unter einem Mikroskop (Nikon Eclipse E 600, Nikon) betrachtet und mit 40 facher Vergrößerung in mehreren Bildern mit Hilfe einer AxioCam (Zeiss) fotografiert. Die Bearbeitung erfolgte mit dem AxioVision Programm Version 3.0.6 SP4 (Zeiss).

Die HE-Bilder zu den einzelnen Schnitten wurden mit einem Drucker (HP 890cxi, Hewlett Packard) ausgedruckt und anschließend von Hand zusammengefügt. Die so erhaltenen Hirnschnittkarten wurden mit Hilfe des sterotaktischen Atlas „The Brain Of Common Marmosets" beschriftet.

\section{$2.6 \quad$ RT-PCR (TaqMan-PCR)}

Das Prinzip der TaqMan ${ }^{\mathrm{TM}} \mathrm{PCR}$ entspricht im Grunde der bereits unter Punkt 2.5.2.4 erklärten PCR. Diese Form der PCR ermöglicht die Amplifikation und den Nachweis des zu detektierenden PCR-Produktes in einer einzigen Reaktionsgefäß (96-wellMikroreaktionsplatten).

Wie für die konventionelle PCR werden auch hier Primer (sense und antisense) benötigt, die auf die bereits bekannte Weise arbeiten und mit der Polymerase für die Amplifikation sorgen. Zusätzlich zu den Primern wird jedoch für den Nachweis des PCR-Produktes auch noch eine Sonde mit einer daran gekoppelten Markierung benötigt. Diese Sonde wird an ihrem 5'-Ende mit einem fluoreszenten Reporter(Signal)-Farbstoff 
und am 3'-Ende mit einem Quencher(Unterdrücker)-Farbstoff markiert. Ist die Sonde intakt und wird bei einer Wellenlänge von $488 \mathrm{~nm}$ angeregt, so fluoresziert sie nicht, da der Quencher-Farbstoff dies durch seine räumlich Nähe zum Reporter-Farbstoff verhindert. Dies wird ein Fluoreszenz-Resonanz-Energietransfer (FRET) genannt. Trifft nun die spezielle AmpliTaq DNA Polymerase, die eine 5'-3'-Exonuclease-Aktivität besitzt, auf die Sonde (Amplifikation), so wird diese verdrängt. Dadurch entsteht eine Y-förmige Sekundärstruktur, welche dann die 5'-3'-Exonuclease aktiviert und so wird die Sonde geschnitten. Die räumliche Nähe zwischen Reporter und Quencher geht verloren, es kann kein Energietransfer mehr stattfinden und eine Fluoreszenz findet statt. Da dies sich von Amplifikation zu Amplifikation mit der Vermehrung des Sequenzabschnittes wiederholt, nimmt auch die Fluoreszenz von Zyklus zu Zyklus zu. Die Fluoreszenz wird durch den Strahl des Argon-Lasers (488 nm) über jeder einzelne Vertiefung der Mikrotiterplatte ausgelöst und Die Fluoreszensemission wird über denselben Leiter gemessen. Sowohl die Emission als auch deren Veränderung während der PCR werden mit dem ABI PRISM 7700 Sequence Detektor registriert und bezüglich einer Standardkurve (definierte Emission für definierte cDNA-Mengen) berechnet.

Die zur Durchführung der TaqMan-PCR benötigten Sonden und Primer, das sogenannte TaqMan-System, mußten speziell für $C$. jacchus ermittelt werden. Mit Hilfe dieser Systeme für IL-1 $\beta$ und IL-1ra wurde es möglich die mRNA in Gehirnproben von $C$. jacchus nachzuweisen. Für die Quantifizierung wurde die NaCl-behandelte Kontrollgruppe gegen die LPS-behandelte Probengruppe in Relation zueinander betrachtet.

\subsubsection{Sonden und Primer für die TaqMan-PCR}

Mit Hilfe der durch die Konstruktion der in-situ-Sonden durch das SequenzLab ermittelten Sequenzen (Punkt 2.5.2), konnten Sonden und Primer für die TaqMan-PCR ermittelt werden.

Dazu wurden die Sequenzen im Textformat ohne Leerzeichen abgespeichert und in das Pirmer-und Sondensuchprogramm des Sequence Detection System 7700 SDS des TaqMan ABI PRISM ${ }^{\mathrm{TM}} 7700$ eingelesen. Unter Vorgabe von festgelegten PCRBedingungen (z.B. Annealingoptimum bei $60^{\circ} \mathrm{C}$, kein G am $5^{\circ}$ Ende der Sonde, Länge 
der Primer mindestens 18 bp usw.) wurden mit Einsatz des Softwaresystem die optimalen Primer und Sonden ausgewählt. Wichtig ist hier vor allem, daß die Sonde mit ihrem 5'-Ende möglichst nahe am 3'-Ende des Sense-Primers liegt und eine Länge von nur 20 bis $30 \mathrm{bp}$ aufweist. Zwischen Sonde und Primer darf außerdem auch keine Komplementarität vorliegen.

Folgende Primer und Sonden wurden ausgewählt:

Primer und Sonde für IL-1 $\beta$

sense Primer $\quad 5^{`}$-GGC ATC CAG CTG CGA CTC T-3‘

antisense Primer 5‘-TAG CCA CGA CAA CCG ACA CA-3‘

Sonde 5'FAM-CCG CCA GCA CTA CAG CAA GGG CTT-TAMRA3`

Primer und Sonde für IL-1ra

sense Primer $\quad 5^{`}$-AGT TGA CAT CAC TGA CCT GAG CAA-3 ${ }^{\star}$

antisense Primer $\quad$ 5'-GGC AGG CAG CAG ACT CGA-3“

Sonde $\quad 5$ 'FAM-ACC TTC ATC CGC TCA GAC AGC GGC-TAMRA3

Die Sonden und Primer wurden bei Eurogentec bestellt.

Mit den Primern wurde eine Probe-PCR (mit der unter Punkt 2.5.2.4 gewonnenen cDNA und dem dort angegebenen Rezept) mit folgenden Bedingungen im Biometrablock vorgenommen:
1. $\quad 94^{\circ} \mathrm{C} \quad 3 \mathrm{~min}$
2. $\quad 94{ }^{\circ} \mathrm{C} \quad 30$ sek
3. $60^{\circ} \mathrm{C} \quad 90 \mathrm{sek}$
4. $\quad 72{ }^{\circ} \mathrm{C} \quad 90 \mathrm{sek}$

Nach Punkt 4 erfolgte der Schritt zu Punkt 2 und wurde 39x wiederholt, bevor das Programm weiter wie folgt fortgesetzt wurde.

5. $\quad 72{ }^{\circ} \mathrm{C} \quad 10 \mathrm{~min}$

6. $\quad 4{ }^{\circ} \mathrm{C} \quad$ Pause

Die Überprüfung erfolgte durch die Auftragung einer Probe des PCR-Ansatzes auf ein 1 \%iges Agarosegel.

Anschließend wurde das PCR-Produkt im bereits bekannten und unter Punkten 2.5.2.5 bis 2 5.2.7 aufgeführten Verfahren kloniert, isoliert und gewonnen. Die so erhaltene DNA wurde im Sequenzlab sequenziert. Die Sequenz ist mit dem DNAsis-Programm überprüft worden und die Einbaurichtung des PCR-Produktes wurde festgestellt. Nach anschließender Linearisierung und in-vitro-Transkription konnte mittels der so erhaltenen cRNA eine definierte Standardkurve für den TaqMan entwickelt werden. 
Für die Standardkurve wurde die RNA in 10er Schritten verdünnt und in die RT eingesetzt. Die so erhaltenen cDNA-Verdünnungsschritte wurden anschließend in einem Probelauf im TaqMan getestet.

\subsubsection{Hirnstanzen}

Wie bereits unter Punkt 2.5.1 beschrieben wurden mit Hilfe der HE-Färbungen Hirnkarten angefertigt. Nach Analyse der in-situ-Hybridisierung und verschiedenen Literaturstellen sind geeignete Gebiete für die Hirnstanzen ausgesucht worden.

Hippocampus, Claustrum und eine Teil des somatosensorischen Cortex wurden dafür bestimmt.

In den beiden schematischen Karten (Abb.9 und Abb.10) sind die ungefähren Hirnbereiche angegeben, in denen die Hirnstanzen gesetzt worden sind. Die Hirnstanzen wurden möglichst immer auf der selben Hirnebene der 14 Probengehirne vorgenommen.

Für die Stanzen aus dem Hippocampus sind $4 \mathrm{~mm}$ Hautstanznadeln verwendet worden. Dabei wurde möglichst der ganze Hippocampusbereich gestanzt (Abb.10).

Bei den Cortexstanzen wurde eine $2 \mathrm{~mm}$ Hautstanznadel verwendet. Es sind damit zwei nebeneinanderliegende Stanzen aus dem äußeren somatosensorischen Cortexbereich entnommen worden (Abb.10).

Für die schmale Claustrumregion ist eine gerade abgeschnittene 1,1 mm Kanüle (Braun) benutzt worden. Auch hier wurden zwei nebeneinander liegende Probenstanzen entnommen (Abb.9).

Die Einordnug der Schnitte in ein Koordinatensystem erfolgte in Anlehnung an den stereotaktischen Atlas „The Brain Of The Common Marmosets“. Die Hippocampusund Cortexstanzen wurden von jedem Gehirn aus einem Schnitt (ca. $4.5 \mathrm{~mm}$ nach frontal von der Anterior-Posterior-Koordinate 0, AP 0; entfernt) entmommen.

Die Claustrumstanzen sind weiter frontal im unteren Bereich des Claustrums gemacht worden (Schnittebene: $9.5 \mathrm{~mm}$ nach frontal von der AP 0 Koordinate entfernt). 


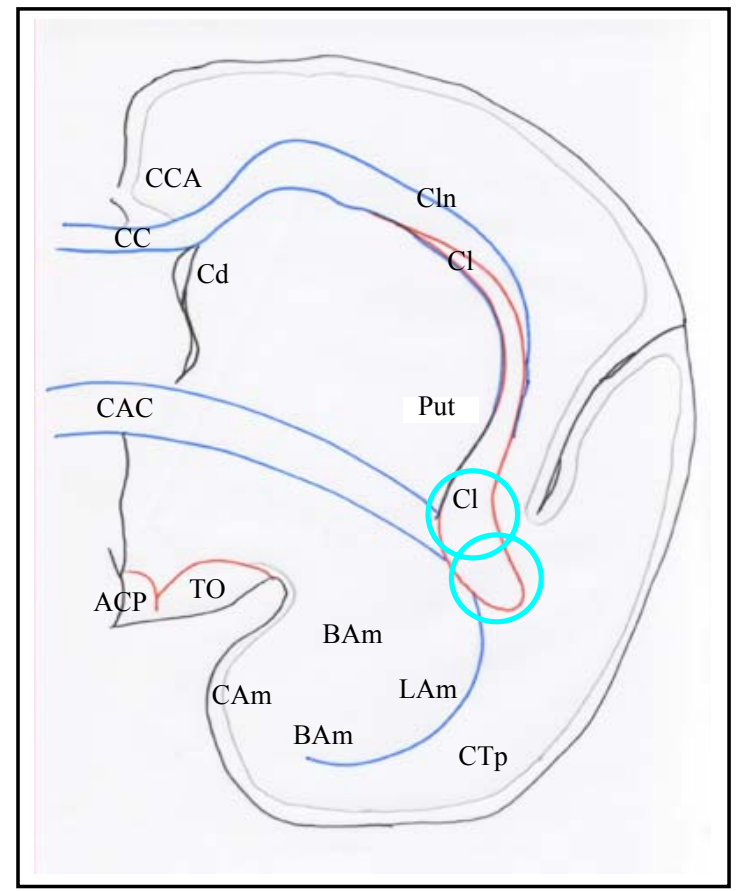

\section{Legende zur Zeichnung}

ACP: Area commissurarae postopticae,

BAm: Nucleus basalis amygdalae, CAC: Commissura anterior cerebri, CAm: Nucleus coticalis amygdalae, CC: Corporus callosum, CCA: Cortex cingularis anterior, Cd: Nucleus caudatus, Cl: Claustrumc, Cln: Cortex insularis, CTp: Cortex temporalis, LAm: Nucleus lateralis amygdalae, Put: Putamen, TO: Tractus opticus

Abb.9: schematische Hirnkarte mit den Positionen für die Claustrumstanze (hellblau); entspricht den Koordinaten $\mathrm{A} 8, \mathrm{H}+7$ bis +9.0 und $\mathrm{R} 7.25$ bis 8.5 im Atlas „The Brain of the Common Marmoset"،

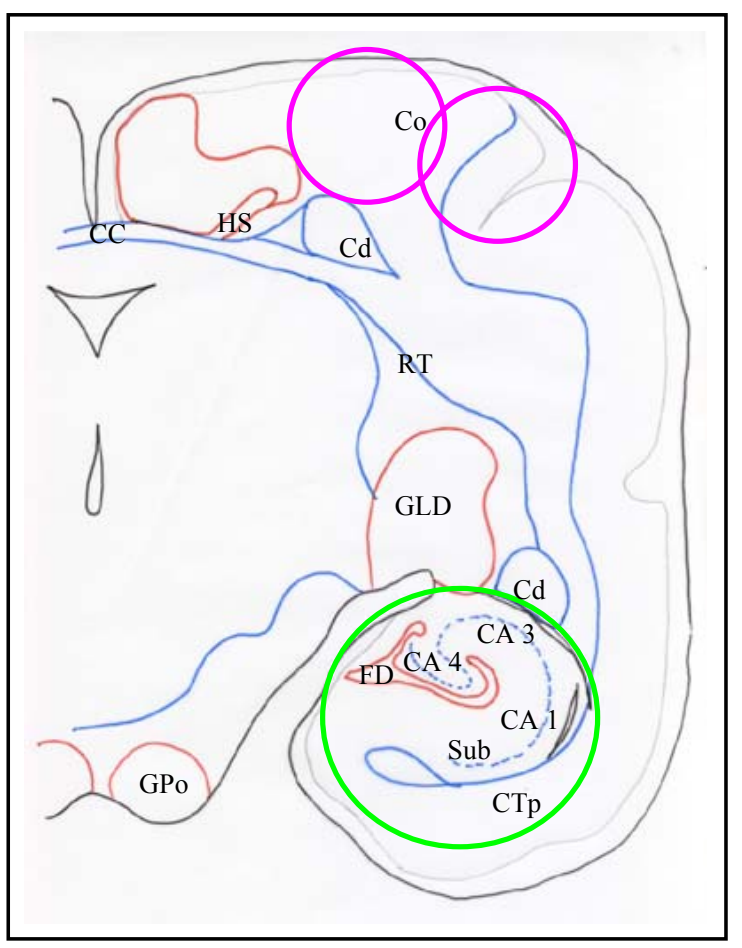

\section{Legende zur Zeichnung}

CA1: Area CA1 hippocampi, CA2: Area CA2 hippocampi, CA3: Area CA3 hippocampi, CA4: Area CA4 hippocampi , CC: Corporus callosum, Cd: Nucleus caudatus, Co: Cortex, CTp: Cortex temporalis, Fd: Fascia dentata, GLD: Corpus geniculatum laterale dorsale, GPo: Griseum pontis, HS: Hippocampus praecommis-suralis, RT: Nucleus reticularis thalami, Sub: Subiculum (hippocampi)

Abb.10: schematische Hirnkarte mit den Positionen für die Stanzen im Cortex (rosa) und Hippocampus (grün); entspricht den Koordinaten $\mathrm{A} 4.5$ : $\mathrm{H}+14.25$ bis +17.5 und $\mathrm{R} 4.75$ bis 9.25 für die Cortexstanzen und $\mathrm{H}+2.5$ bis +6.5 und R4.5 bis 9.0 für die Hippocampusstanzen im Atlas ,The Brain of the Common Marmoset" 


\subsubsection{RNA-Aufarbeitung}

Zur Entnahme der Stanzen sind die gefrorenen Schnitte jeweils kurz angetaut worden und dann wurde eine vorgekühlten Nadel vorsichtig auf das betreffende Areal aufgesetzt und gedreht. Die Probe blieb in der Nadel hängen und wurde anschließend sofort in einem mit $350 \mu 1$ Lysis-Puffer gefülltem E-Cup abgeschwemmt. Um die Gewebeproben zu zerkleinern wurde erst kurz gevortext und dann für 10 Sekunden im Ultraschallbad homogenisiert. Die weitere Aufarbeitung erfolgte mit dem RNeasy-Kit nach dem bereits unter Punkt 2.5.2.1 angegebenen Protokoll. Die Eluierung der RNA erfolgte mit nur $35 \mu 1$ Velcorin-Wasser. Eine 1:16 Verdünnung der so gewonnenen RNA wurde am Photometer gemessen.

\subsubsection{Ribo Green}

Die Messung am Photometer ergab sehr niedrige Werte (zwischen 6 bis $50 \mu \mathrm{g} / \mathrm{ml}$ ). Da das Photometer in diesem Bereich aber unzuverlässig mißt, wurde eine sensitivere Methode zur Messung angewendet.

Die sogenannte RiboGreen ${ }^{\circledR}$-Messung mit dem RiboGreen ${ }^{\circledR}$ RNA Quantification Kit (Molecular Probe) ermöglicht, die genaue RNA-Menge mittels Fluoreszenz festzustellen. Bei RiboGreen ${ }^{\circledR}$ handelt es sich um einen patentierten Zyanfarbstoff. Ungebundenes Zyan fluoresziert nicht, zeigt aber, gebunden an RNA eine bis 1000 fach höhere Fluoreszenz mit sehr wenig Hintergrund (Technical Information Molecular Probe). Freie Nuleotide und Proteine stören dabei überhaupt nicht. Noch vorhandene DNA wird durch einen DNAse-Schritt entfernt. Mit RiboGreen ${ }^{\circledR}$ können verdünnte RNA-Proben zwischen $1 \mathrm{ng} / \mathrm{ml}$ und $1 \mu \mathrm{g} / \mathrm{ml}$ gemessen werden. Dabei werden zwei Zyan-Konzentrationen verwendet. Mit der einen, dem sogenannten High-Range-Assay, werden Konzentrationen von $20 \mathrm{ng} / \mathrm{ml}$ bis zu $1 \mu \mathrm{g} / \mathrm{ml}$ gemessen. Der Low-Range-Assay hingegen ist für Konzentrationen von $1 \mathrm{ng} / \mathrm{ml}$ bis $50 \mathrm{ng} / \mathrm{ml}$ geeignet.

Für die Durchführung des Assays wurden sterile und RNAse-freie Arbeitsbedingungen angewendet, die für das Arbeiten mit RNA üblich sind.

Es wurde der Low-Range-Assay verwendet. Für die Standardkurve wurden $200 \mu 1$ zwischen $0 \mathrm{ng} / \mathrm{ml}$ und $50 \mathrm{ng} / \mathrm{ml}$ RNA-Endkonzentration in die Meßküvetten pipettiert. Die Proben wurden zunächst 1:100 vorverdünnt. Davon sind entweder die $100 \mu 1$ direkt 
für die Messung eingesetzt (Claustrum und Cortex), oder eine 1:4 Verdünnung aus der Vorverdünnung erstellt (Hippocampus) worden. $\mathrm{Zu}$ dem Probenvolumen wurde noch die gleiche Menge Low-Range-Lösung gegeben, gemischt und in Meßküvetten gefüllt. Nach einer Inkubation von 5 Minuten sind die Proben an einem VersaFluor ${ }^{\mathrm{TM}}$ Flurometer (BIO-RAD) gemessen worden.

Mit dem GraphPad Prism Programm wurde mit den Werten der Standardproben eine Regressionsgerade berechnet und die Konzentration der Proben-RNA mittels Extrapolierung bestimmt.

\subsubsection{Reverse Transkriptase}

Zur Durchführung der RT wurden die RNA-Proben auf $10 \mathrm{ng} / \mu 1$ eingestellt.

$\mathrm{Zu}$ diesem Ansatz wurde je $1 \mu$ l Random Primer (Invitrogen) zugegeben und nach vortexen, sowie zentrifugieren für 10 Minuten bei $70{ }^{\circ} \mathrm{C}$ inkubiert (geändertes RTRezept). Dieser Schritt diente zur Lösung der RNA-Sekundärstrukturen, die sich bei Raumtemperatur bilden. Im Anschluß sind die Proben sofort auf Eis gekühlt worden. Nach dem unter Punkt 2.5.2.2 beschriebenen Verfahren wurde mit $10 \mathrm{mM}$ dNTP Mix (Invitrogen) und der bekannten Reversen Transkriptase eine RT durchgeführt. Die cDNA wurde nach Beendigung des letzten Inkubationsschrittes wieder sofort auf Eis gekühlt, dann zentrifugiert und bei $-20{ }^{\circ} \mathrm{C}$ eingefroren.

\subsubsection{Durchführung des TaqMan-Assays}

Die TaqMan-PCR wurde auf 96-well Microtiterplatten (MicroAMP Optical 96-weelreaction Plate, PE Applied Biosystems) durchgeführt.

Die Standards sind in Doppelbestimmungen, die Proben in Einzelbestimmungen durchgeführt worden. Als Referenz und Kontrolle wurde mindestens 8 mal Ampuwawasser anstelle der cDNA pipettiert.

Für die TaqMan-PCR wurden bei einem Reaktionsvolumen von $24 \mu 1$ pro Ansatz (well) pipettiert:

$$
\begin{array}{rll}
12.5 & \mu 1 & 2 \text { x Puffer } \\
0.75 & \mu 1 & \text { sense Primer }(300 \mathrm{nM})
\end{array}
$$


$0.75 \mu 1 \quad$ antisense Primer $(300 \mathrm{nM})$

$0.562 \mu \mathrm{l} \quad$ Sonde $(225 \mathrm{nM})$

$6.438 \mu 1 \quad$ Ampuwa

$4 \quad \mu 1 \quad$ cDNA-Probe, NTC oder

$2 \quad \mu l \quad$ Standard (+2 $\mu$ l Ampuwa)

Zur Analyse wurde die Platte mit optischen Deckelketten verschlossen, kurz zentrifugiert, und in den TaqMan gestellt. Folgendes Programm mit insgesamt 40 Zyklen wurde gestartet:

1. $50{ }^{\circ} \mathrm{C} \quad 2 \mathrm{~min}$

2. $95^{\circ} \mathrm{C} \quad 10 \mathrm{~min}$

3. $95^{\circ} \mathrm{C} \quad 15 \mathrm{sek}$

4. $\quad 60^{\circ} \mathrm{C} \quad 1 \mathrm{~min}$

Nach Punkt 4 erfolgt der Schritt wieder zu Punkt 3. Dieser Zyklus wurde insgesamt 40

Mal wiederholt. Die gemessene Emission (ct) wurde anhand der Standardkurve in Konzentrationswerte umgerechnet.

\subsubsection{Auswertung des TaqMan Assays}

Zur Auswertung wurden die Konzentrationswerte mit Hilfe von einer Exel-Tabelle prozentrelativiert. Dazu wurde der Mittelwert der Meßwerte der Gruppe der NaClbehandelten Tiere als Kontrollgruppe gleich $100 \%$ gesetzt. Die Gruppe der LPSbehandelten Tiere ist dazu in das Verhältnis gebracht worden.

Im Anschluß wurden diese Werte mit dem GraphPad Prism-Programm einem zweiseitigem t-Test unterzogen. Zur Berechnung der Signifikanz wurde ein p-Wert von $<0.05$ als Grenze angesetzt. 


\section{$3 \quad$ Ergebnisse}

\subsection{Quantitative Bestimmungen von Hormon- und Cytokin- spiegeln im Serum}

Für die Bestimmung der Konzentrationen der Hormone Testosteron und Cortisol wurde jeweils ein für humanes Serum optimiertes RIA-Kit verwendet. Die Prolaktinspiegel wurden mit einem humanem IRMA-Kit gemessen. Für die Cytokine IL-1 $\beta$, IL-6 wurden ebenfalls humane ELISA-Kits verwendet. Lediglich für TNF- $\alpha$ wurde auf ein Rhesus-Affen-ELISA-Kit zurückgegriffen.

Alle statistischen Auswertungen wurden mit Hilfe des zweiseitigen t-Tests vorgenommen, bei dem die NaCl-Gruppe immer als Kontrollgruppe genommen wurde. Als Grenzwert für die Signifikanz wurde ein P-Wert von $\leq 0.05$ gesetzt. Signifikante Werte wurden mit einem * gekennzeichnet. Es wurden jeweils die Mittelwerte mit SEM aufgetragen. 


\subsubsection{Testosteron-Assay}

Bei der Auswertung des Testosteron-Werte zeigte sich eine deutliche Erniedrigung (um $\sim 58.4 \%)$ der Steroidspiegel in der LPS-behandelten Gruppe im Vergleich zur Kontrolle.

Während in den Kontrollen ein durchschnittlicher Testosterongehalt von $1.3 \mathrm{ng} / \mathrm{dl} \pm 0.4$ ng/dl gemessen worden ist, wurde in der LPS-behandelten Gruppe eine geringere Testosteronkonzentration gemessen. Mit $0.5 \mathrm{ng} / \mathrm{dl} \pm 0.09 \mathrm{ng} / \mathrm{dl}$ zeigte sich eine hemmende Auswirkung der LPS-Behandlung. Die statistische Auswertung ergab keine Signifikanz, da der P-Wert bei 0.0685 lag.

\section{Testosteron}

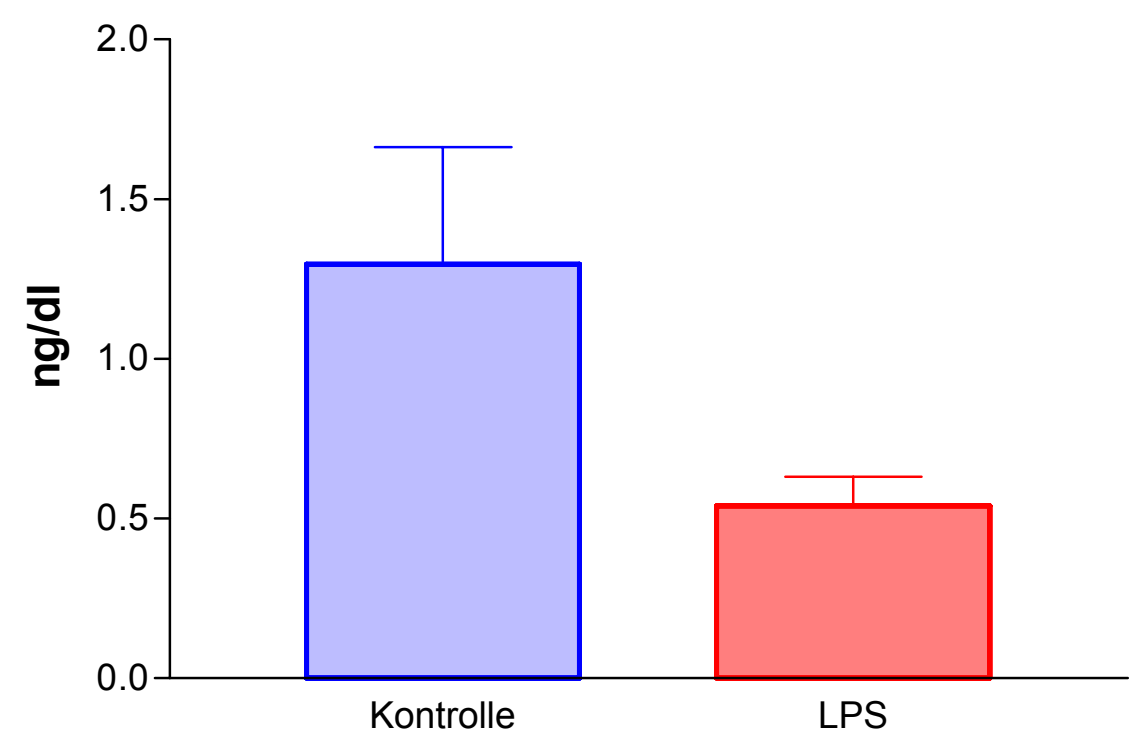

Abb.11: Testosteronkonzentration im Serum der Kontrollgruppe (NaCl-behandelt) und der LPSbehandelten Gruppe als Mittelwerte mit SEM ( $\mathrm{n}=7$ pro Gruppe) 


\subsubsection{Cortisol-Assay}

Mit einer mittleren Konzentration von $118.5 \mu \mathrm{g} / \mathrm{dl} \pm 2.0 \mu \mathrm{g} / \mathrm{dl}$ zeigte der Cortisolwert der LPS-behandelten Gruppe eine um 19 \% höhere Konzentration gegenüber der Kontrollgruppe mit einem Mittelwertwert von $99.5 \mu \mathrm{g} / \mathrm{dl} \pm 6.4 \mu \mathrm{g} / \mathrm{dl}$. Die LPSBehandlung wirkte sich stimulierend aus.

Die statistische Auswertung ergab einen signifikanten Effekt, da der P-Wert bei 0.0157 lag.

\section{Cortisol}

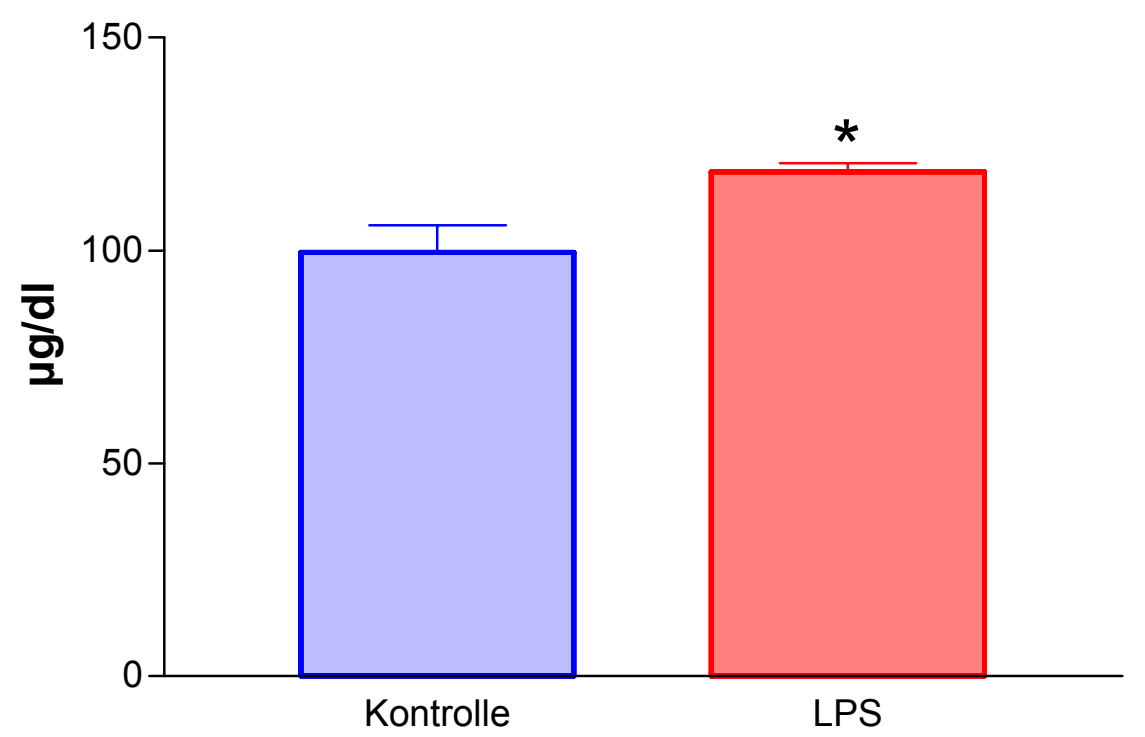

Abb.12: Cortisolkonzentration im Serum der Kontrollgruppe (NaCl-behandelt) und der LPS-behandelten Gruppe als Mittelwerte mit SEM ( $\mathrm{n}=7$ pro Gruppe); * kennzeichnet eine Signifikanz von $\leq 0.05$. 


\subsubsection{Prolaktin-Assay}

Um die Konzentration von Prolaktin im Serum von C. jacchus bestimmen zu können, wurde ein humanes IRMA-Kit verwendet. Zur Valiedierung der Kreuzreaktivität wurden drei verschiedene Volumina jeder Probe gemessen.

Die Prolaktin-Konzentration im Serum der Kontrolle lag im Mittel bei $9.2 \mathrm{ng} / \mathrm{ml} \pm 1.0$ ng/ml. Bei der LPS-behandelten Gruppe wurden erhöhte Werte von $20.4 \mathrm{ng} / \mathrm{ml} \pm 4.9$ $\mathrm{ng} / \mathrm{ml}$ gemessen.

Die Prolaktin-Konzentration lag somit bei der LPS-Gruppe rund doppelt so hoch, wie bei der Kontrolle. Die LPS-Behandlung hat sich auch hier stimulierend ausgewirkt. Die statistischen Auswertung ergab einen signifikanten Unterschied $(\mathrm{P}-\mathrm{Wert}=0.046)$.

\section{Prolaktin}

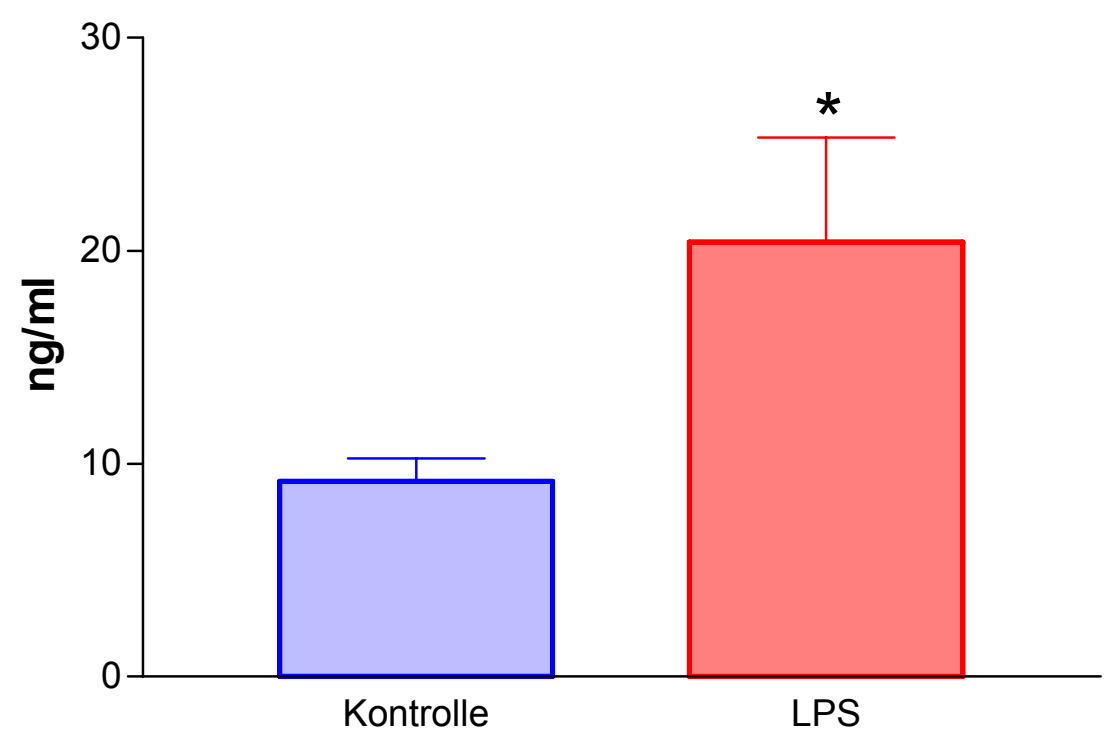

Abb.13: Prolaktinkonzentration im Serum der Kontrollgruppe (NaCl-behandelt) und der LPS-behandelten Gruppe als Mittelwerte mit SEM ( $\mathrm{n}=7$ pro Gruppe); * kennzeichnet eine Signifikanz von $\leq 0.05$.

\subsubsection{IL-6-Assay}

Um die IL-6-Konzentration im Serum von C. jacchus zu bestimmen wurde ein humanes ELISA-Kit verwendet. Die Proben beider Gruppen zeigten, egal in welcher 
Konzentration sie eingesetzt wurden, keine meßbare Extinktion innerhalb der Standardkurve. Ein Effekt der LPS-Behandlung auf die IL-6-Konzentration konnte daher nicht nachgewiesen werden. Daher kann keine Aussage über die Auswirkung von LPS auf IL-6 getroffen werden.

\subsubsection{IL-Assay}

Ein humanes ELISA-Kit ist zur Bestimmung der IL-1 $\beta$-Serumkonzentration verwendet worden. Mit diesem Kit ließen sich Konzentrationen von IL-1 $\beta$ im Serum von Krallenäffchen bestimmen. Von den fünf eingesetzten Konzentrationen einer Verdünnungsreihe (konzentriert, 1:2, 1:4) wurde die dritte Verdünnung (1:4) zur Auswertung herangezogen.

LPS steigerte die IL-1 $\beta$-Konzentration 200fach gegenüber der Kontrollgruppe. Die statistische Auswertung zeigte eine mehr als deutliche Signifikanz mit einem P-Wert von $<0.0001$.

\section{Interleukin-1 beta}

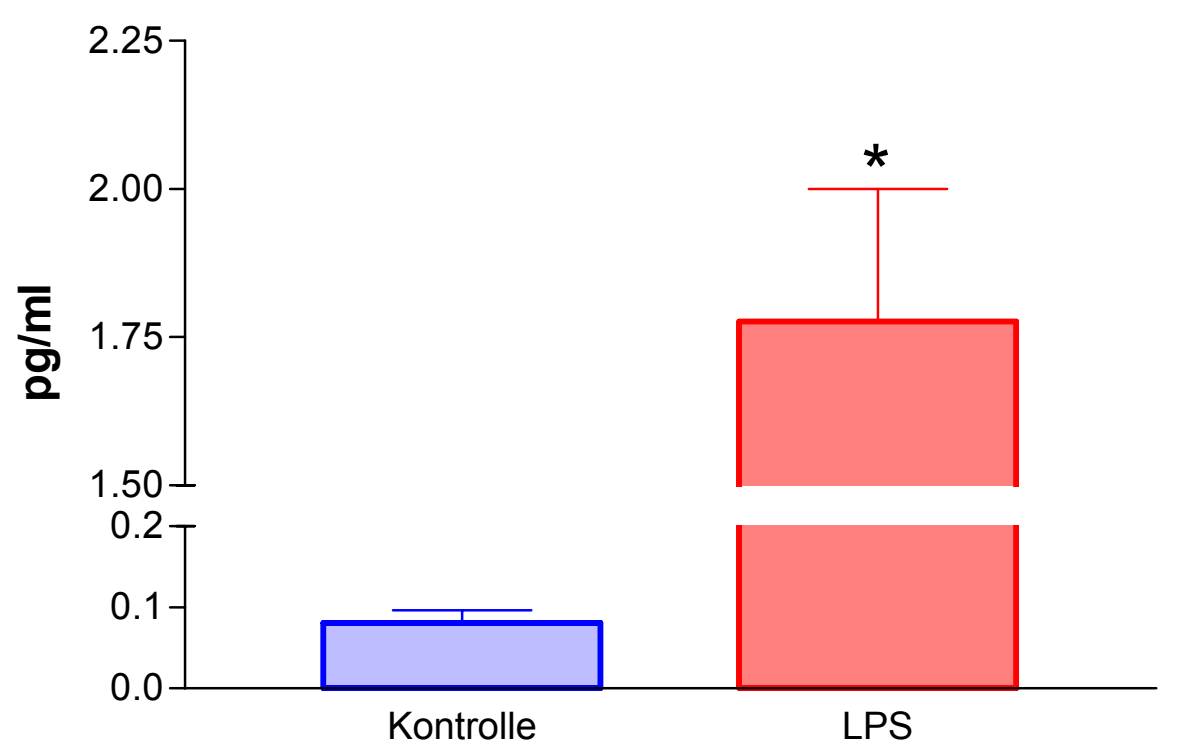

Abb.14:IL-1 $\beta$-Konzentration im Serum der Kontrollgruppe (NaCl-behandelt) und der LPS-behandelten Gruppe als Mittelwerte mit SEM ( $\mathrm{n}=7$ pro Gruppe); * kennzeichnet eine Signifikanz von $\leq 0.05$. 


\subsubsection{TNF- $\alpha$-Assay}

Bei dem TNF- $\alpha$ Assay handelte es sich um einen Assay zur Bestimmung von TNF- $\alpha$ im Serum von Rhesusaffen. Von den drei eingesetzten Konzentrationen einer Verdünnungsreihe wurde hier die mittlere (1:2) zur Auswertung genommen.

Es ergab sich eine mittlere Konzentration der Kontrollgruppe von $0.04 \mathrm{pg} / \mathrm{ml} \pm 0.001$ pg/ml. Die Werte der LPS-behandelten Gruppe, mit einem Mittel von 343 pg/ml \pm 101.1 pg/ml, lagen sehr hoch. Damit ist ein mehr als deutlicher Effekt der LPS-Gabe zu beobachten. Die statistische Auswertung ergab eine Signifikanz mit einem P-Wert von 0.0084 .

\section{TNFalpha}

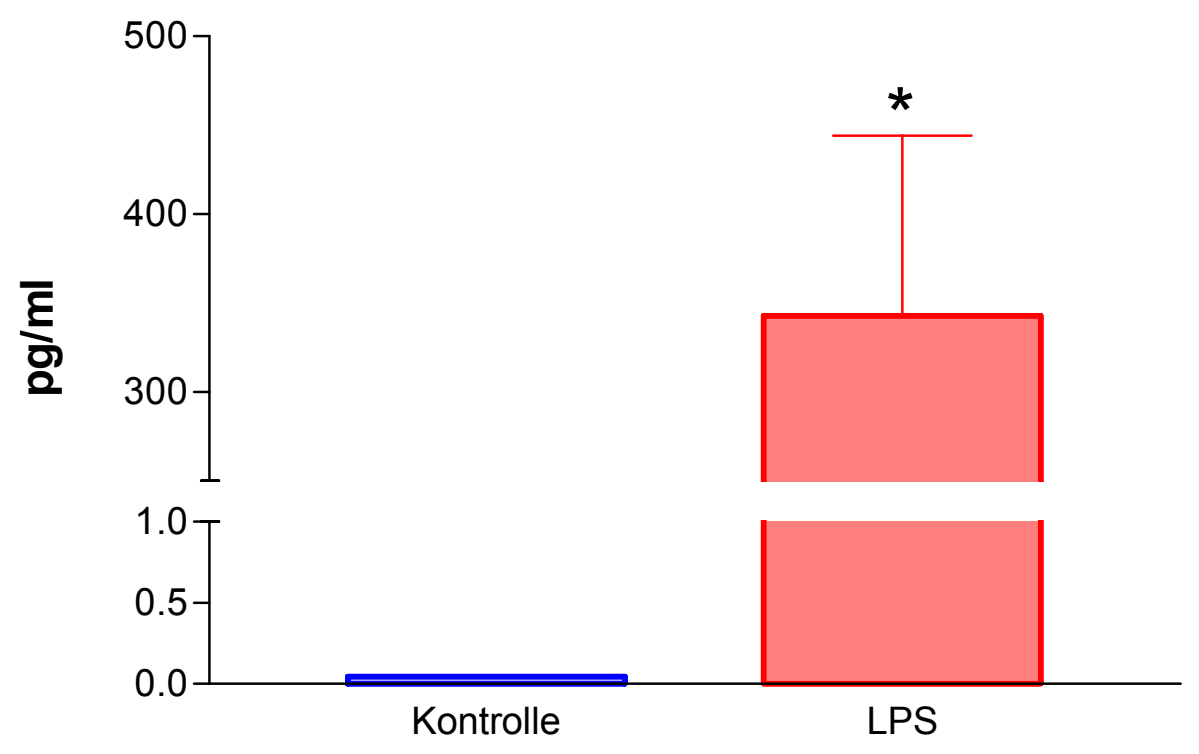

Abb.15: TNF- $\alpha$-Konzentration im Serum der Kontrollgruppe (NaCl-behandelt) und der LPS-behandelten Gruppe als Mittelwerte mit SEM ( $\mathrm{n}=7$ pro Gruppe); * kennzeichnet eine Signifikanz von $\leq 0.05$. 


\subsection{Histologie}

\subsubsection{Hämatoxilin-Eosin-Übersichtsfärbungen}

Die Färbung der HE-Schnitte mittels des TechMate ${ }^{\mathrm{TM}}$ Horizon garantierte einen geringen Reagenzienverbrauch bei gleichmäßiger Färbung. Von den HE-gefärbten Schnitten eines Kontroll- (Nr. 3) und eines LPS-behandelten Tieres (Nr. 1) wurden Fotos erstellt, ausgedruckt und diese zu Hirnkarten zusammengefügt und mit Hilfe des sterotaktischen Atlas „The Brain Of The Common Marmoset" beschriftet, um so genaueres Kartenmaterial zu erhalten. Mit Hilfe dieser Karten konnten schematische Zeichnungen zur Orientierung in den anderen Gehirnen angefertigt werden. Makroskopisch waren keine Unterschiede zwischen den Gehirnen des Kontroll- und des LPS-behandelten Tieres hinsichtlich der Hirnstrukturen oder deren Erscheinungsbild erkennbar.

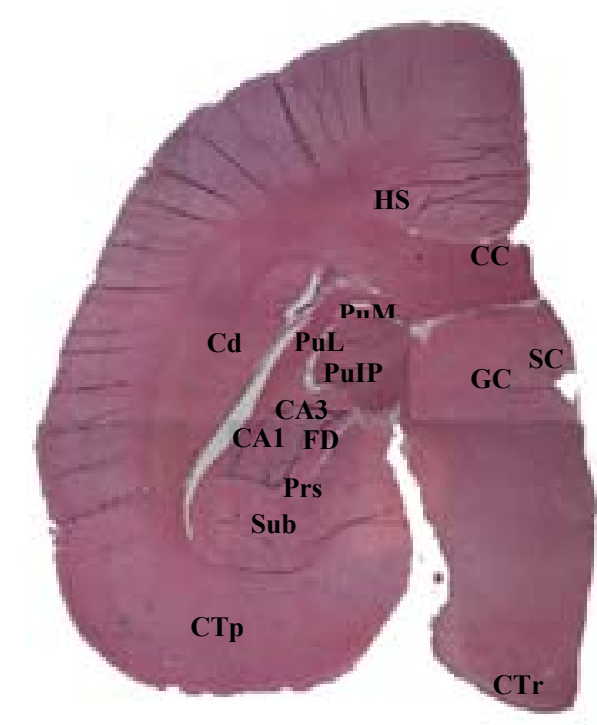

A

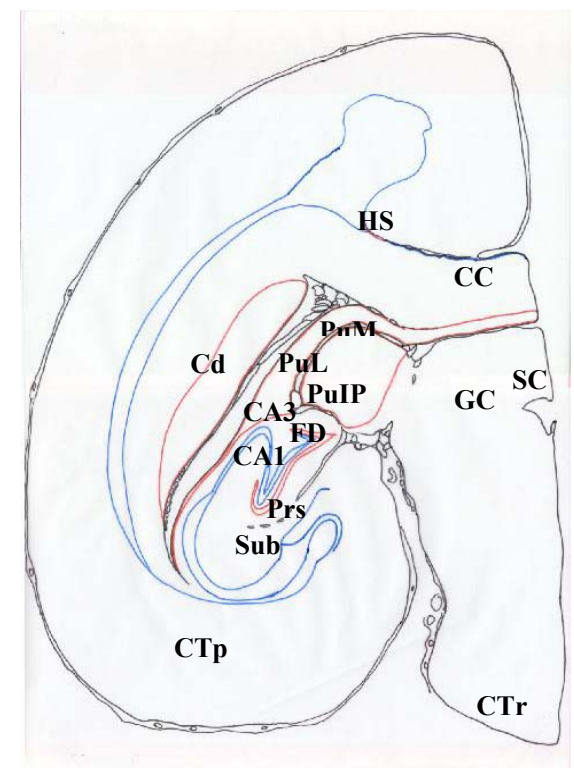

B

Abb.16: Beispiel einer Zuordnung von Hirnregionen in einem HE gefärbten Schnitt (A) mittels des Atlas „The Brain of the Common Marmoset“ (Karte A2) zur Hestellung einer Schemazeichnung (B) C. jacchus, Männchen (Gehirn 3, Schnitt 2580): Frontalschnitt, rechte Gehirnhälfte

CA1: Area CA1 hippocampi, CA3: Area CA3 hippocampi, CC: Corporus callosum, Cd: Nucleus caudatus, CTp: Cortex temporalis, Fd: Fascia dentata, GC: Substantia grisea centralis, HS: Hippocampus praecommis-suralis, Prs: Regio praesubicularis, PuI: Pulvinar inferior, PuL: Pulvinar lateralis, PuM: Pulvinar medialis, SC: Suculus calarinus, Sub: Subiculum (hippocampi) 


\subsubsection{In-situ-Hybridisierungs-Sondensequenzen}

Mit Hilfe der unter 2.5.2 erklärten Aufarbeitung gelang es Sonden zum Nachweis von IL-1 $\beta$, IL-1ra, IL-1RI und IL-1RII im Hirngewebe von C. jacchus zu entwickeln. Folgende partiellen Sequenzen konnten kloniert und sequenziert werden:

Interleukin 1 beta (IL-1 $\beta)$

GATGGCCCTAAACAGATGAAGTGCTCTTTCCAGGACCTGGACCTCTGCCCTGTGGATG GCGGCATCCAGCTGCGACTCTCCCGCCAGCACTACAGCAAGGGCTTCAGGCAGGTTGT GTCGGTTGTCGTGGCTATGGAGAAGCTGAGGAGGATGCCAGTTTACTGCCCACAGACC TTCCAGGACAATGACCTCAGCACCTTCTTTCCCTTCATCTTTGAAGAAGAACCTATCAT CTTCGACACATGGGATAATGAGGCTTATGTGTGCGATGCACCTGTACGATCCCTGAACT GCACACTCCGGGATGCACAACAAAAATGCTTGGTGATGTCCGGCCCATATGAACTGAA AGCTCTCCACCTCCAGGGACAGGATCTGGAGCAACAAGTGGTGTTCTCCATGTCCTTTG TGCAAGGAGAAGAAAGTAATGACAAAATACCTGTGGCCTTGGGCCTCAAAGAAAAGA ATCTGTACCTGTCCTGTGTGCTGAAAGATAAGAAGCCCACTCTACAGCTGGAGAGTGT AGAT

Interleukin 1 rezeptor antagonist (IL-1 ra)

AACCAACTAGTTGCTGGATACCTGCAAGGACCCAATGTCTATTTAGAAGAAAAGATAG ATGTGGTACACATTGAGCCTCATTCTCTGTTCTTGGGAATCCATGGAGGGAAGATGTGC CTGTCCTGTGTCAAGACTGGTGATGAGACCAGACTCCAGCTGGAGGCAGTTGACATCA CTGACCTGAGCAAGAACAAAAAGCAGGACGAGCGTTTCACCTTCATCCGCTCAGACAG CGGCCCCACGACCAGTTTCGAGTCTGCTGCCTGCCGGGGCTGGTTCCTCTGCACGGCGA TGGATGCCGACCAGCCCGTCAGCCTCACCAATACGCCCAACAAGGGCATCATGGTCAC CAAATTCTACTTCCAG

Interleukin 1 Rezeptor Typ I (IL-1RI)

TACTGGAAGTGGAATGGGTCATTAATTGATGAAGATGACCCAGTGCTGGAGGAAGACT ACTACAGTGTGGAAAATCCTTCAAACAAAAAAAAAAGTACCCTCATCACAGTGCTTAA TATATCGGAAATTGAAAGTAGATTTTATGAACATCCATTTACCTGTTTTGCCAAGAATA CACATGGTGTAGATGCAGCGTATATTCAGTTAATATATCCAGCCCCTAATTTCCAGAAG CACATGATTGGTATATGTGTGATGTTGACAGTCATAATTATGTGTTCCATTTTCATCTAT AAAATCTTCAAGATTGATATTGTGCTTTGGTACAGGGATTCCTGCTATGTTTTTCTTCCA GTAAAAGCTTCAGGTGGAAAGACCTATGATGCATATATACTGTATCCAAAGACCACTG GGGGAAGGGTCTACCTCTGACTGTGATATTTTTGTGTTTAAAGTCTTGCCTGAGGTCTT GGAAAAACAGTGTGGATATAAGCTGTTCATTTATTGGAAGAAG

Interleukin 1 Rezeptor Typ II (IL-1RII)

TGGCTTCTGCCAGCCTTGCAGGGAGACTCTGGCACCTACATCTGCACTACTAGAAATGC CTCTTACTGTGACGAAATGTCCATTGAGCTCAGGGTTTTTGAGAATACGGATGCTTCCC TGCCTTTCATCTCATACCCGCAAATTTTAACATTGTCAACCTCTGGGGTATTAGTGTGC CCTGACCTGAGTGAATTCATCCGTAACAAAACTGACGTGAAGATTCAGTGGTACAAGG ATTCTCTTCTTTTGGATGAAGGCAATGAGAAATTTCTAAGTGTGAGGGGGACCACTCAC TTACTTGTGCACGACGTGGCCCTGGAAGATGCGGGCTATTACCCGCTGTGTCCTGACAT TTGCCCACAAAGGCCAACAATACAACATCAGTAGGAGTATCGAGCTACGCATCAAGAA AAAACAAGAGGAGACCATTCCTGTGATTATTTCCCCCCTCAGGACCATATCGGCTTCTC TGGGGTCAAGACTGACAATCCCGTGTAAGGTGTTTCTGGGAACCGGCACA

rot: sense Primer blau: antisense Primer

Abb.17: Partielle Sequenzen für IL-1 $\beta$, IL-1ra, IL-1RI und IL-1RII 


\subsubsection{Sequenzhomologien}

Zur Überprüfung der Sondensequenzen wurden die partiellen Sequenzen von C. jacchus mit jeweiligen Sequenzen des Menschen verglichen. Dazu wurden Sequenzen aus der PubMed Datenbank verwendet. Der Abgleich der Sequenzen wurde mit dem PubMed Blast 2 Sequenzes Programm durchgeführt.

Die nicht homologen Basenpaare wurden prozentual auf die Gesamtbasenpaare berechnet.

\subsection{Interleukin-1 beta}

Die Übereinstimmung der Basen der partiellen C. jacchus Sequenz mit den Basen der Sequenz des Menschen (PubMed ID: GI 33789) lag bei $92.4 \%$.

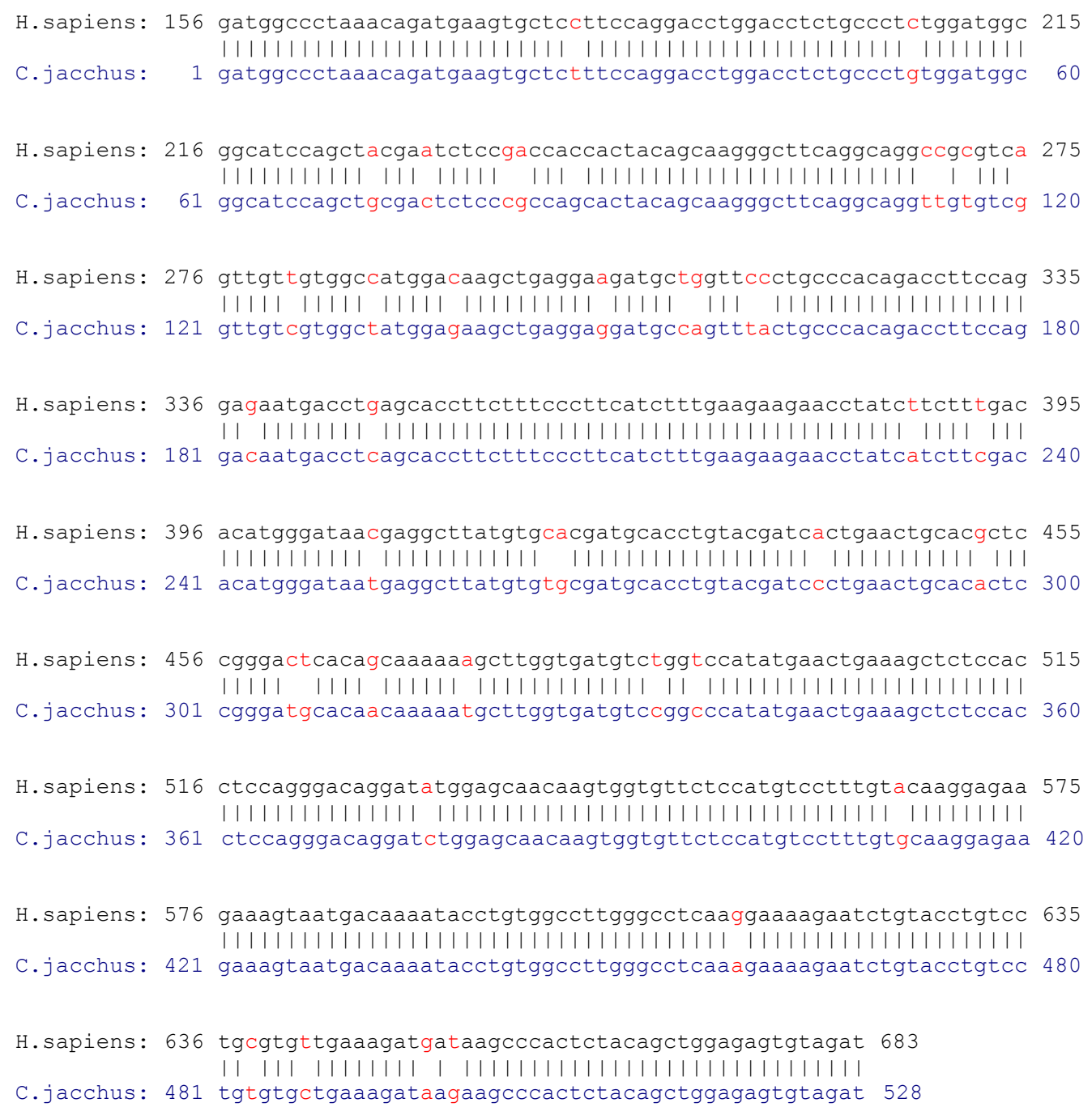

Abb.18: Sequenzvergleich zwischen der IL-1 $\beta$ vom Menschen (H. sapiens) und Krallenäffchen (C. jacchus). Unterschiede in den Sequenzen wurden rot markiert. 
Ein weiterer Vergleich der Sequenz vom Neuweltaffen $C$. jacchus mit der Sequenz von einem Altweltaffen, dem Javaneraffen (Macaca fascicularis), ergab eine Homologie von $89.6 \%$ (Daten hier nicht gezeigt).

\subsection{Interleukin-1 rezeptor antagonist}

Die Homologie der Basen der partiellen C. jacchus Sequenz mit den Basen der IL-1ra Sequenz des Menschen (PubMed ID: GI 10835146) lag bei $92.6 \%$.

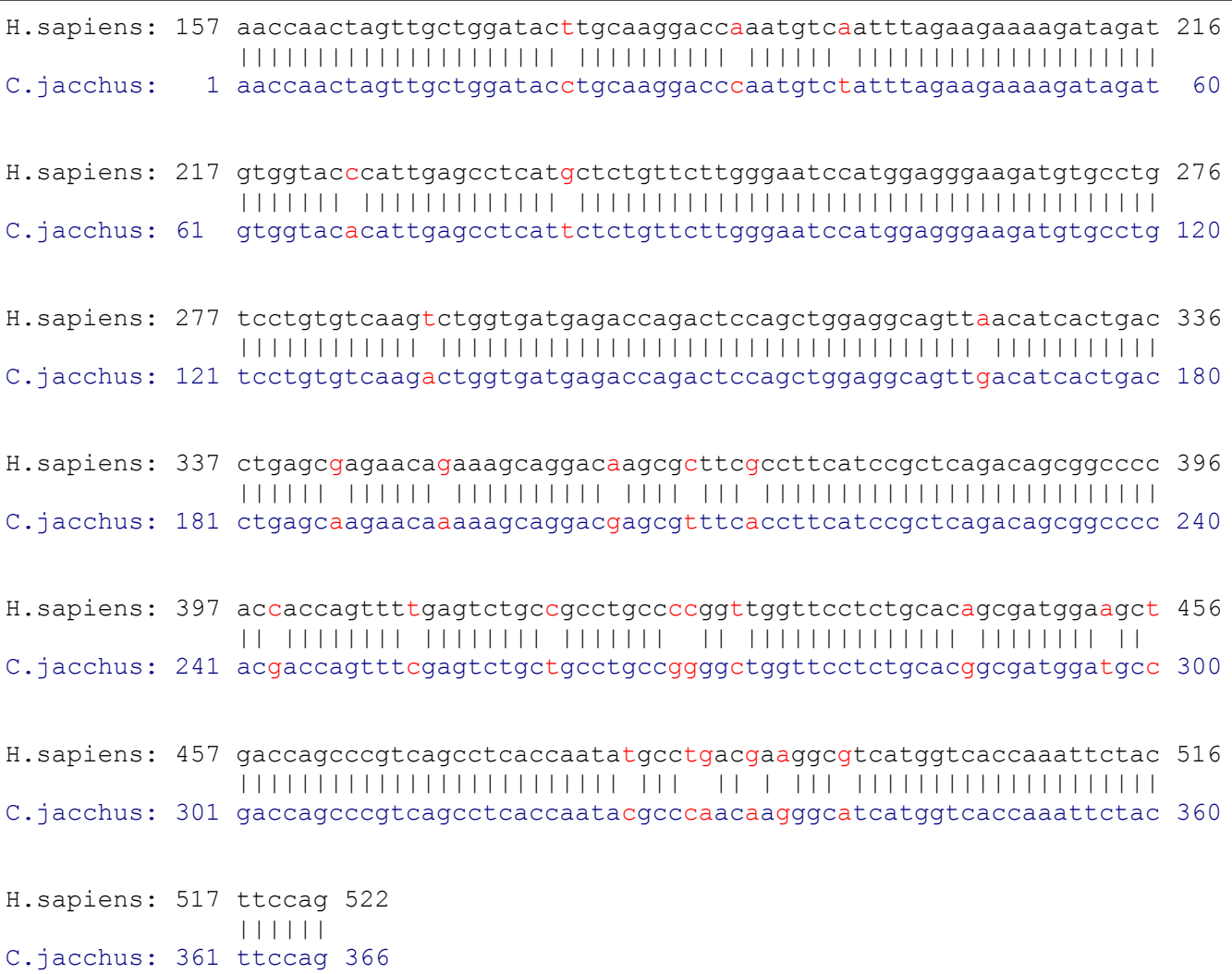

Abb.19: Sequenzvergleich zwischen der IL-1ra vom Menschen (H. sapiens) und Krallenäffchen (C. jacchus). Unterschiede in den Sequenzen wurden rot markiert 


\subsection{Interleukin-1 Rezeptor Typ I}

Der Vergleich der partiellen C. jacchus Sequenz mit der Sequenz des Menschen (PubMed ID: GI 27894331) ergab eine Übereinstimmung von $94.3 \%$.

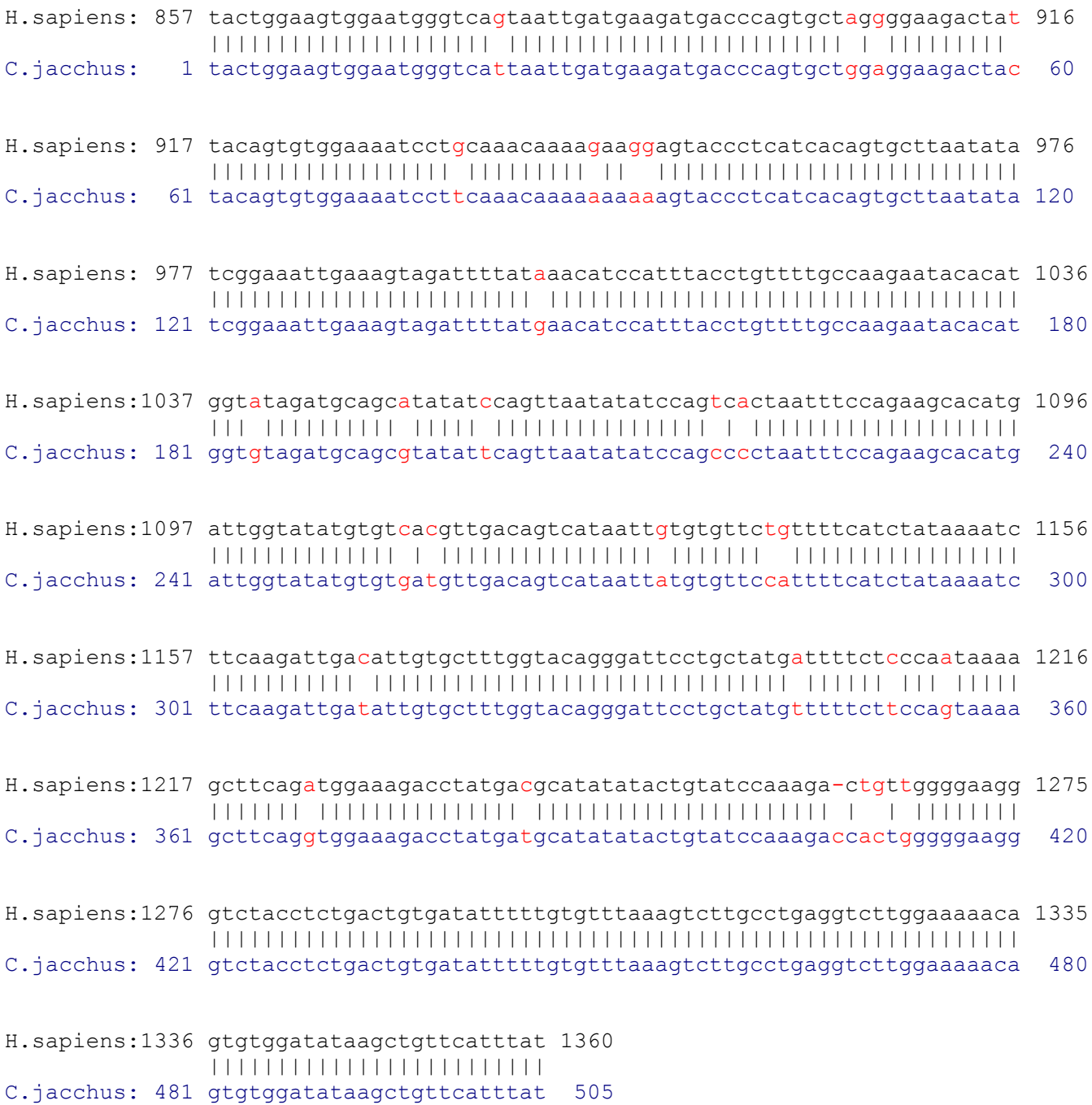

Abb.20: Sequenzvergleich zwischen der IL-1RI vom Menschen (H. sapiens) und Krallenäffchen $(C$. jacchus). Unterschiede in den Sequenzen wurden rot markiert. 


\subsection{Interleukin-1 Rezeptor Typ II}

Für den IL-1RII wurde eine Übereinstimmung der partiellen C. jacchus Sequenz mit der Sequenz des Menschen (PubMed ID: GI 27894332) von 94.0 \% festgestellt.

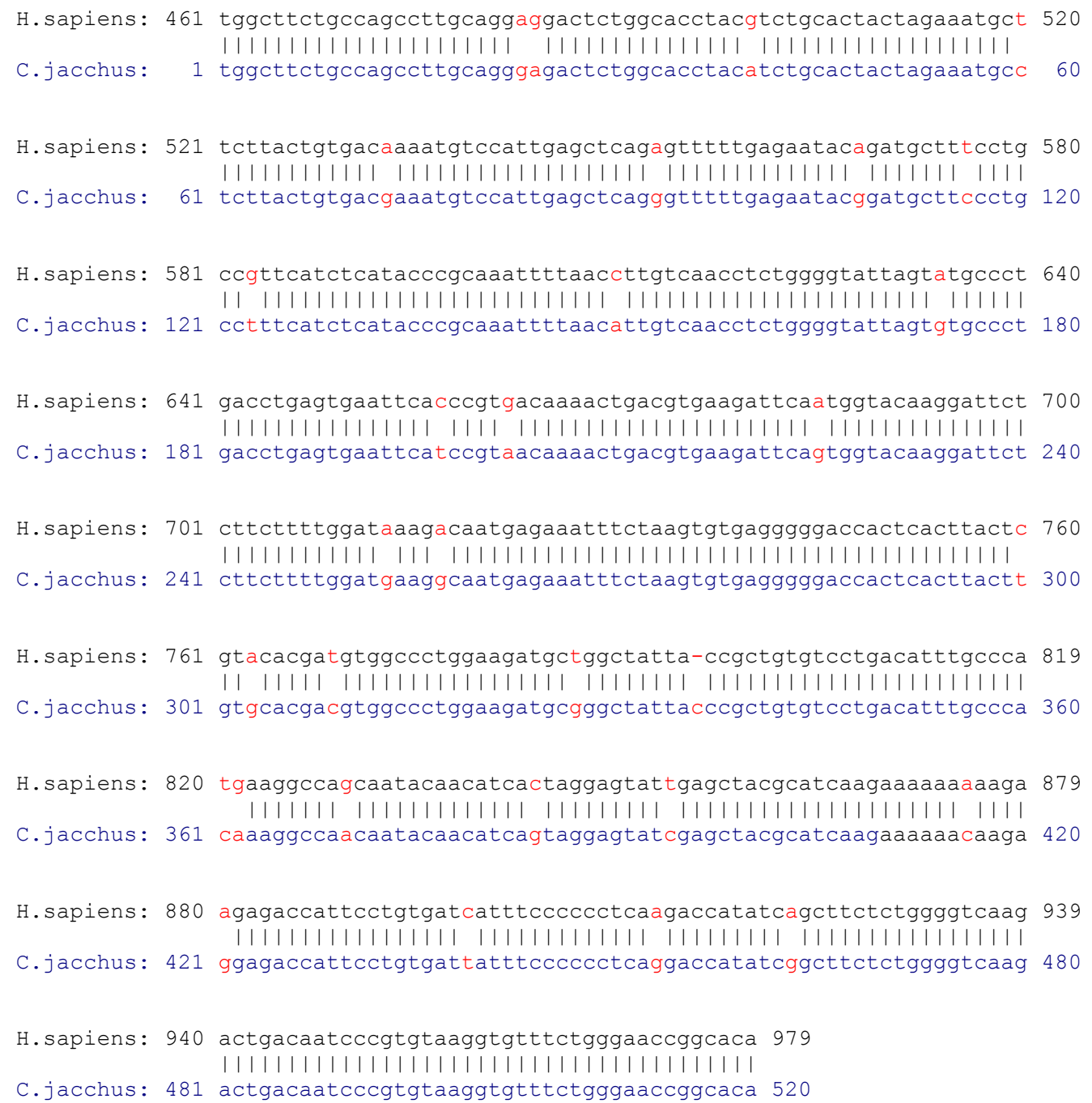

Abb.21: Sequenzvergleich zwischen der IL-1RII vom Menschen (H. sapiens) und Krallenäffchen $(C$. jacchus). Unterschiede in den Sequenzen wurden rot markiert. 


\subsubsection{In-situ-Hybridisierungs Nachweismethoden}

Es wurden insgesamt 8 dig-markierte Sonden und 8 biotin-markierte Sonden hergestellt. Als Negativ-Kontrollen dienten die sense Sonden, die mit der mRNA nicht hybridisieren können.

Alle Antisense-Sonden zeigten eine spezifische positive Reaktion. Alle mit den SenseSonden behandelte Schnitte waren dagegen negativ. Kontrollschnitte, auf die nur Hybridisierungspuffer gegeben worden ist, waren ebenfalls immer negativ. Daraus läßt sich schließen, daß es keine unspezifischen Bindungen von den verwendeten Reagenzien, z.B. dem anti-dig-AP, im Gewebe gab.

Von den beiden verwendeten in-situ Methoden erwies sich die GenPoint Methode als sensibeler, da die Detektion der Zielsequenz klarer im Schnitt erschien. Zudem ließ sich diese neue Methode einfach und an einem einzigen Tag (innerhalb von 5-6 Stunden) anwenden. Weniger Reagenzien mußten angesetzt werden, wodurch sich eine Fehlerquelle minimierte. Die Hybridisierungstemperatur von $37^{\circ} \mathrm{C}$ erwies sich als vorteilhaft, zudem braucht kein deonisiertes Formamid (giftig) zur Reduzierung der Hybridisierungstemperatur in die Hybridisierungskammer gefüllt werden.

Die Spezifität der Sonden bezüglich der mRNA wurde mit Hilfe von Northern Blots überprüft. Die Ergebnisse entsprachen bereits in Vorversuchen vorgenommenen positiven Überprüfungen radioaktiv-markierter Sonden mittels radioaktiven Northern Blots.

\subsubsection{Immunhistologische Nachweismethoden}

Es waren keine kommerziell zu erwerbenden Antikörper speziell gegen die Proteine des IL-1 Systems von Krallenaffen verfügbar. Darum wurden polyklonale und monoklonale humane Antikörper benutzt.

Die bereits unter Punkt 2.5.3.1 aufgelisteten Antikörper (Tab.5) wurden ausgetestet. Alle bis auf den IL-1 $\beta$ Antikörper der Firma SantaCruz kreuzreagierten. Die monoklonalen Antikörper der Firma R\&DSystems ließen sich mit dem EnVision Systemen kombinieren. Auch die gebrauchsfertigen Antikörper für human-NSE und human-GFAP erwiesen sich für Detektionen im C.jacchus Gewebe als verwendbar. Die in der Tabelle 5 angegebenen Antikörperkonzentrationen wurden in diversen 
Vorversuchen entwickelt. Jedoch bleibt zu bemerken, daß die Antikörper der Firma R\&DSystems extrem empfindlich auf eine Unterbrechung des Gefriervorgangs reagierten und deshalb die Aliquots nach Gebrauch verworfen werden mußten und nicht, wie bei anderen Antikörpern wieder verwendet werden konnten. Zudem kam es im Laufe eines Jahres zu einem extremen Aktivitätsverlustes dieser Antikörper, was dazu führte die Antikörper, zwecks besserer Stabilisierung bei $-70^{\circ} \mathrm{C}$ zu lagern. Auch erwies sich ein anderer Verdünnungspuffer mit stabilisierenden Eigenschaften (DakoCytomation), mit dem die lyophilisierten Antikörper statt mit 1x PBS zum Ende der Arbeit versuchsweise aufgelöst wurden, als günstiger.

Die Kontrollschnitte, auf die statt des Antikörpers nur Verdünnungspuffer aufgetragen wurde, waren in allen Fällen negativ.

Die Färbungen, die mit dem sensitiveren DAB+ durchgeführt worden sind, sind stärker, als die, mit dem einfacheren DAB.

Die Färbung mit dem Immunautostainer erforderte keine andere Antikörperkonzentration.

Sowohl bei der Färbung von Hand, als auch bei der Färbung mit dem Stainer kam es zu ungleichmäßigen Färbeergebnissen, deren Ursachen nicht geklärt werden konnten.

\subsubsection{Nachweis der Expressionen von IL-1 $\beta$, IL-1ra, IL-1RI und IL-1RII mittels ISH und IHC}

Aufgrund der angefertigten Katen über die Expressonverteilung (Punkt 3.2.3.1) von IL1 $\beta$, IL-1ra, IL-1RI und IL-1RII wurden verschiedene Hirnregionen ausgewählt, um die ISH und die IHC näher zu untersuchen. Folgende Hirnareale wurden ausgesucht:

$>$ Cortex (speziell Cortex frontalis)

$>$ Striatum (Nucleus caudatus und Putamen)

$>$ Claustrum

$>$ Hippocampus (Area CA1-CA4 hippocampi, Fascia dentata und die Zellschicht zwischen den Area CA1-CA4 und der Fascia dentata

Unter den nachfolgenden Punkten wurden die Expression der mRNA von IL-1 $\beta$, IL-1ra, IL-1RI und IL-1RII und des jeweiligen Proteins beschrieben. Zudem wurden 
exemplarische Beispiele für die In-situ-Hybridisierung und die Immunhistologie aufgeführt. Beispiele für positive Signale der ISH bzw. IHC wurden mit gelben Pfeilen markiert. Beispiele für positive Glia- oder Neuronzellen wurden mit einem grünen Pfeil gekennzeichnet.

Die Unterscheidung von Neuron- und Gliazellen erfolgte auch aufgrund ihres morphologischen Erscheinungsbildes. Gliazellen zeichneten sich durch eine rundlichere Erscheinung aus und wiesen zumeist viele kleine Verzweigungen (sternförmig) auf. Die Neurone in den betrachteten Gebieten waren größer als die Gliazellen und hatten eine eher längliche Form. Die auslaufenden Axone der Neurone waren oft zu erkennen und boten ebenfalls einen deutlichen Hinweis auf den Zelltyp.

\subsubsection{Interleukin-1 beta (IL-1 $\beta$ )}

In allen Cortexbereichen war mit Hilfe der IH neben einer mRNA Expression (ISH) eine Protein-Expression in Neuronenzellen deutlich nachzuweisen. Der Proteinnachweis mittels des Antikörpers zeigte eine gleichmäßige starke Verteilung von IL-1 $\beta$ im Cortex. Im Nucleus caudatus und dem Putamen, die den sogenannten Streifenkörper (Corpus striatum) bilden, konnte ebenfalls eine IL-1 $\beta$ mRNA Expression und auch das Protein, nachgewiesen werden. Das Claustrum, wie auch die hypothalamische Region zeigten eine IL-1 $\beta$ mRNA Expression. In den einzelnen Regionen des Hippocampus zeigten sich positive Signale vereinzelt in und zwischen der Facia dentata und den Area CA1-CA4 hippocampi. Die großen neuronalen Pyramidenzellen der Area CA1-CA4 selbst wiesen keine mRNA-Expressionssignale auf. Es liegt die Vermutung nahe, daß es sich hier um eine gliale Expression (typische kleine Zellform) handelt. Der Proteinnachweis hingegen zeigte eine starke Expression in diesen Neuronen. Wie in Abb.22.1 waren in den Schnitten im Hippocampus deutlich positive ISH-Signale der biotin-antisense Sonde zu erkennen. 


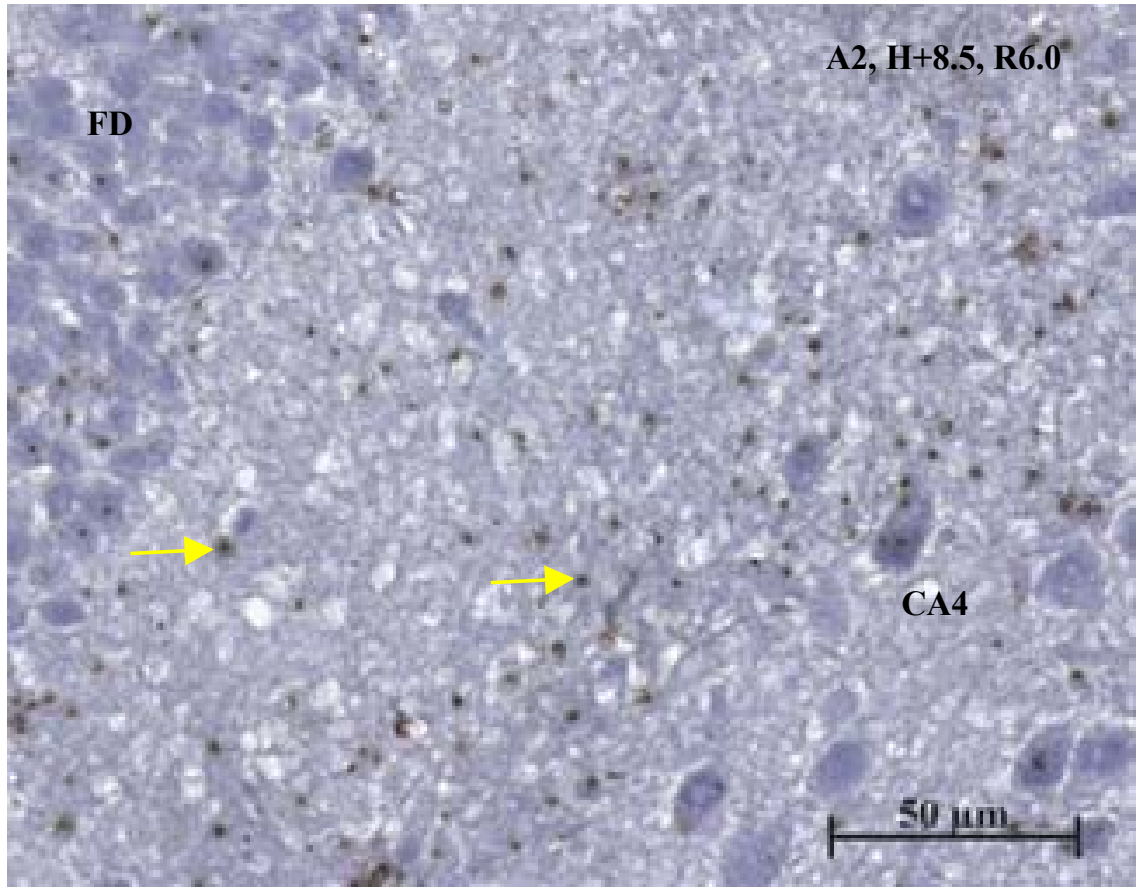

Abb.22.1: $\quad$ Positive ISH-Signale (Beispiele durch gelbe Pfeile gekennzeichnet) der biotin-IL-1 $\beta$ Sonde (braun, DAB+) in der Fascia dentata (FD) und der Area CA4 hippocampi (CA4) des Hippocampus mit Hämatoxilin (blau) gegengefärbt. C. jacchus, Männchen (Gehirn 3, Schnitt 2491) 400x

In Abb.22.2 ist ebenfalls der Hippocampus zu sehen, wie in Abb.22.1. Es wurde mit einem Antikörper für IL-1 $\beta$ ein Nachweis des Proteins vorgenommen.

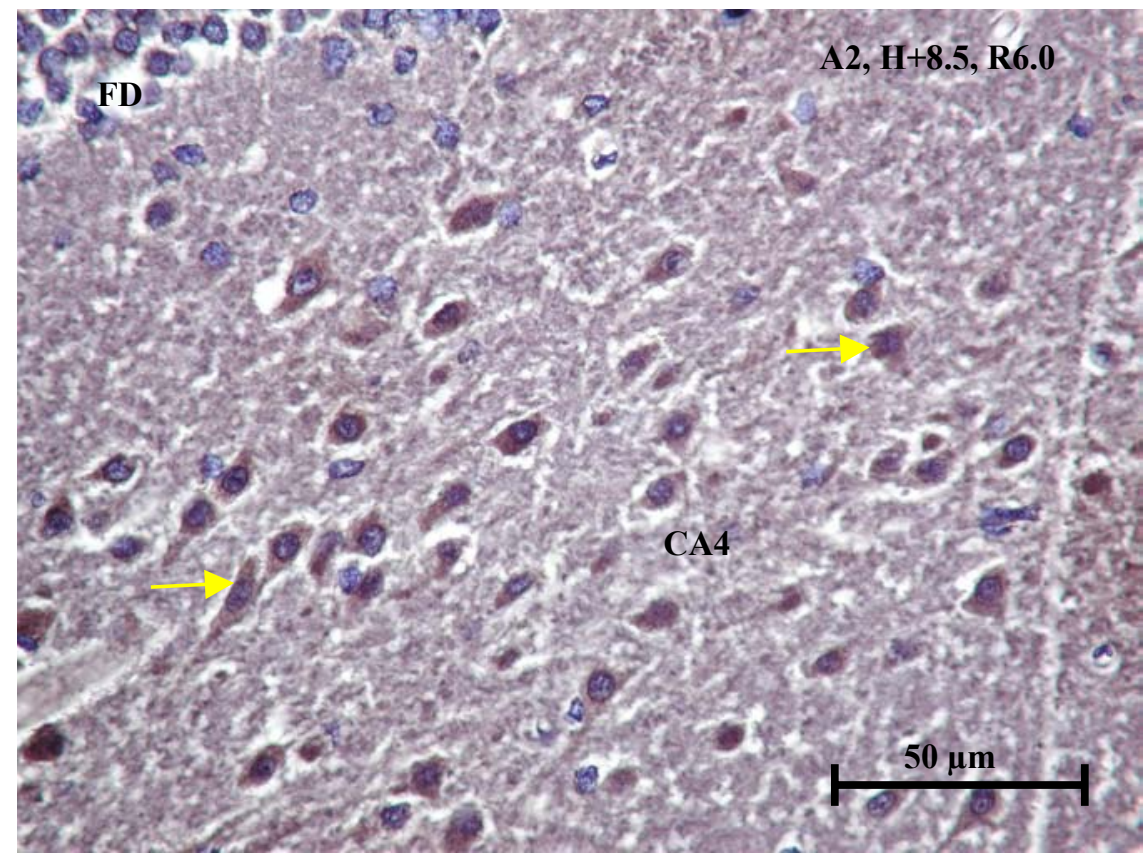

Abb.22.2: $\quad$ Positive IHC-Signale ( $\quad$ Pelbe Pfile) des IL-1 $\beta$-Antikörpers (braun, DAB+) in der Fascia dentata und der Area CA4 hippocampi des Hippocampus mit Hämatoxilin (blau) gegengefärbt. C. jacchus, Männchen (Gehirn 1, Schnitt 2622) 400x 


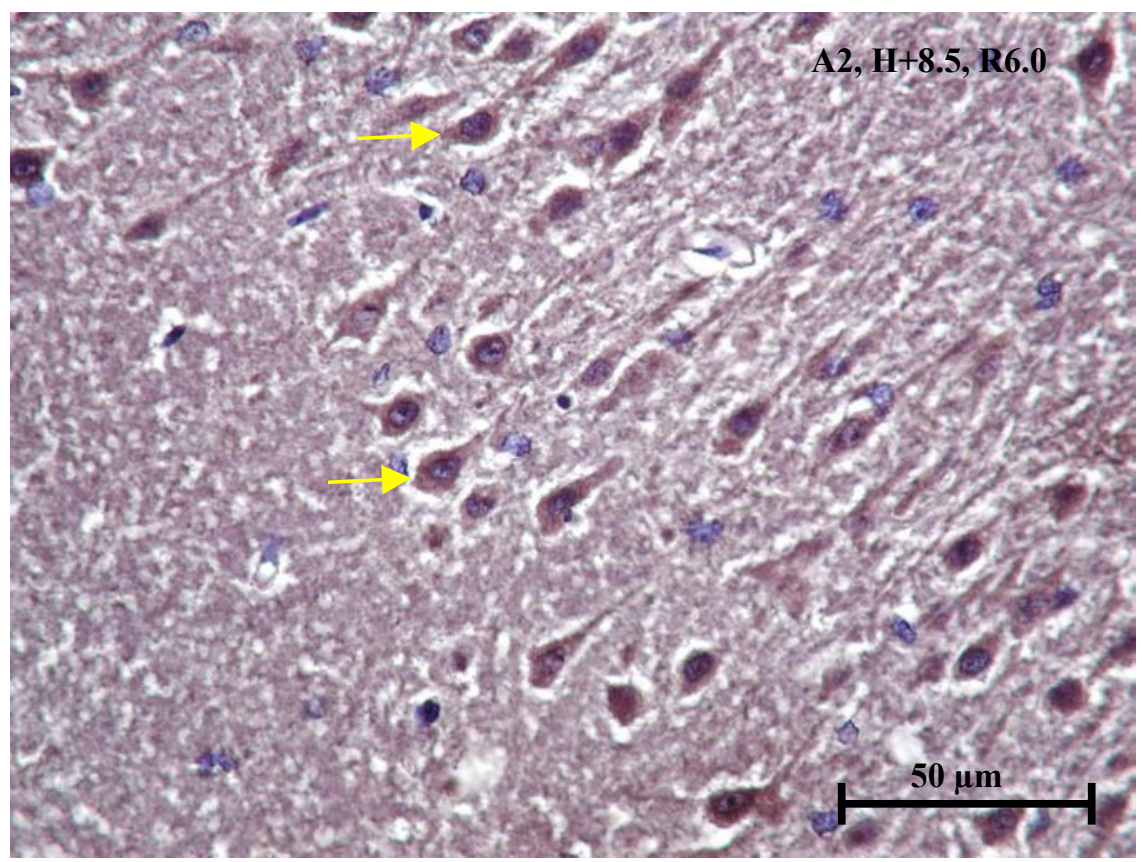

Abb.22.3: Positiver IHC-Nachwies (gelbe Pfeile) des IL-1 $\beta$-Antikörpers (braun, DAB+) in der Area CA3 hippocampi (CA3) des Hippocampus mit Hämatoxilin (blau) gegengefärbt. C. jacchus, Männchen (Gehirn 3, Schnitt 2462) 400x

Das Protein IL-1 $\beta$ war stark auf den großen Neuronenzellen des Hippocampus in den verschiedenen Gebieten CA1-CA4 nachzuweisen (Abb.22.3). 


\subsubsection{Interleukin-1 Rezeptor Antagonist (IL-1ra)}

Die Expression vom Rezeptor-Antagonisten war in denselben Hirnregionen wie auch beim Liganden IL-1 $\beta$ nachzuweisen, jedoch immer etwas schwächer als die Expression von IL-1 $\beta$ ausgeprägt. IL-1ra zeigte in den Cortexregionen eine dem Liganden IL-1 $\beta$ ähnliche Expressionsverteilung. Die IHC wies positive Neurone im Cortex nach. In den Regionen des Striatums scheint die Expression von IL-1ra hauptsächlich glialen Ursprungs.

Im Claustrum konnte eine mRNA Expression mittels ISH nachgewiesen werden. Im Hippocampus ließ sich deutlich eine neuronale, aber auch eine gliale mRNA Expression nachweisen.

Im Vergleich zu IL-1 $\beta$ zeigte sich in der ISH sehr deutlich im Hippocampus sowohl eine Expression glialen Ursprungs, als auch eine Expression in den Neuronen der Gebiete CA1-CA4 hippocampi (23.1-23.2).

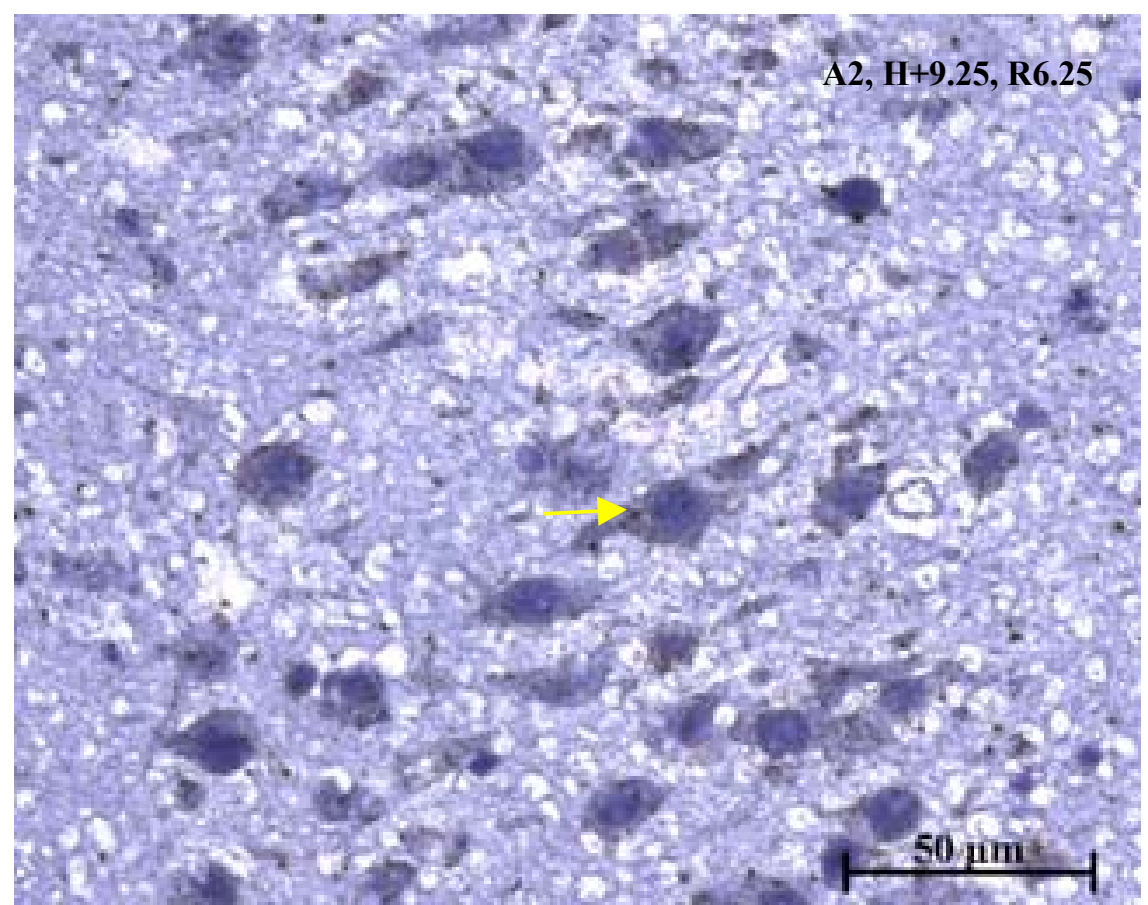

Abb.23.1: $\quad$ Positive ISH-Signale (Beispiel durch einen Pfeil gekennzeichnet) der biotin-IL1ra-Sonde (braun, DAB+) in der Area CA3 hippocampi des Hippocampus mit Hämatoxilin (blau) gegengefärbt. C. jacchus, Männchen (Gehirn 3, Schnitt 2493) 400x 


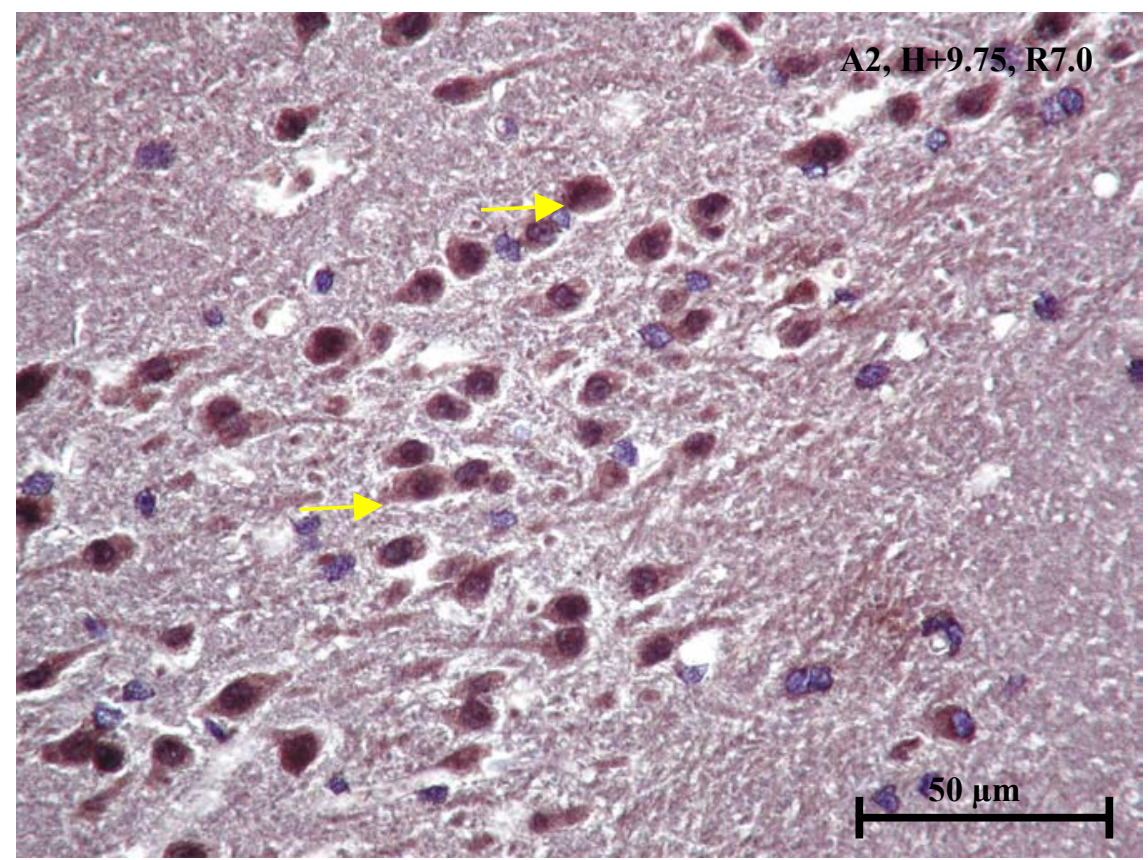

Abb.23.2: $\quad$ Positive IHC-Signale ( $\quad$ Pfeile) des IL-1ra-Antikörpers (braun, DAB+) in der Area CA3 hippocampi des Hippocampus mit Hämatoxilin (blau) gegengefärbt. C. jacchus, Männchen (Gehirn 3, Schnitt 2463) 400x

Im Cortex exprimieren Neuronen das Protein IL-1ra (Abb.23.3). Deutlich waren auch hier die Axone der Neurone zu erkennen.

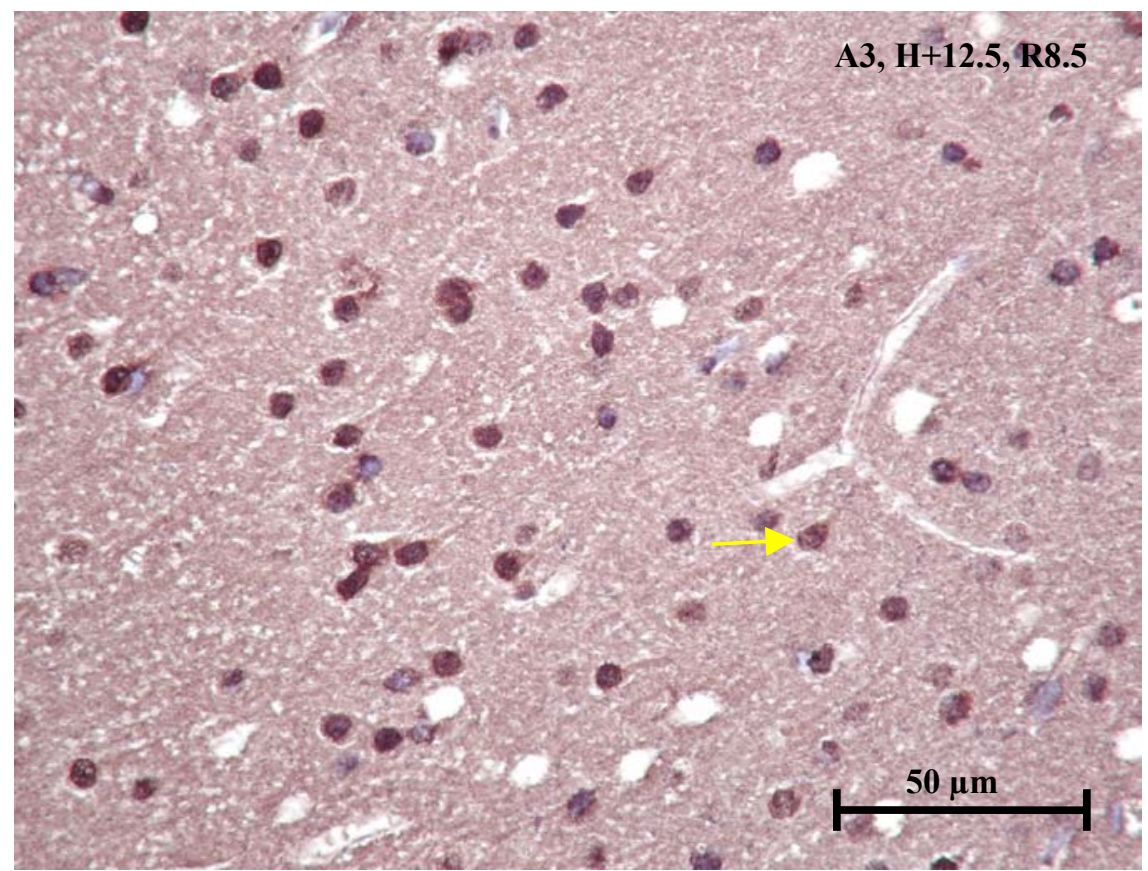

Abb.23.3: $\quad$ Positive IHC-Signale ( $\quad$ Pfeil) des IL-1ra-Antikörpers (braun, DAB+) im Cortex mit Hämatoxilin (blau) gegengefärbt. C. jacchus, Männchen (Gehirn 1, Schnitt 3503) 400x 
Auch im Claustrum wird IL-1ra exprimiert, wie die deutlich positiven Signale der digIL-1ra Antisense-Sonden in Abb.23.5. zeigen. Abb. 23.4 zeigt den Vergleich zur Antisense Sonde die Sense Sonde, die keine positiven Signale auslöst.

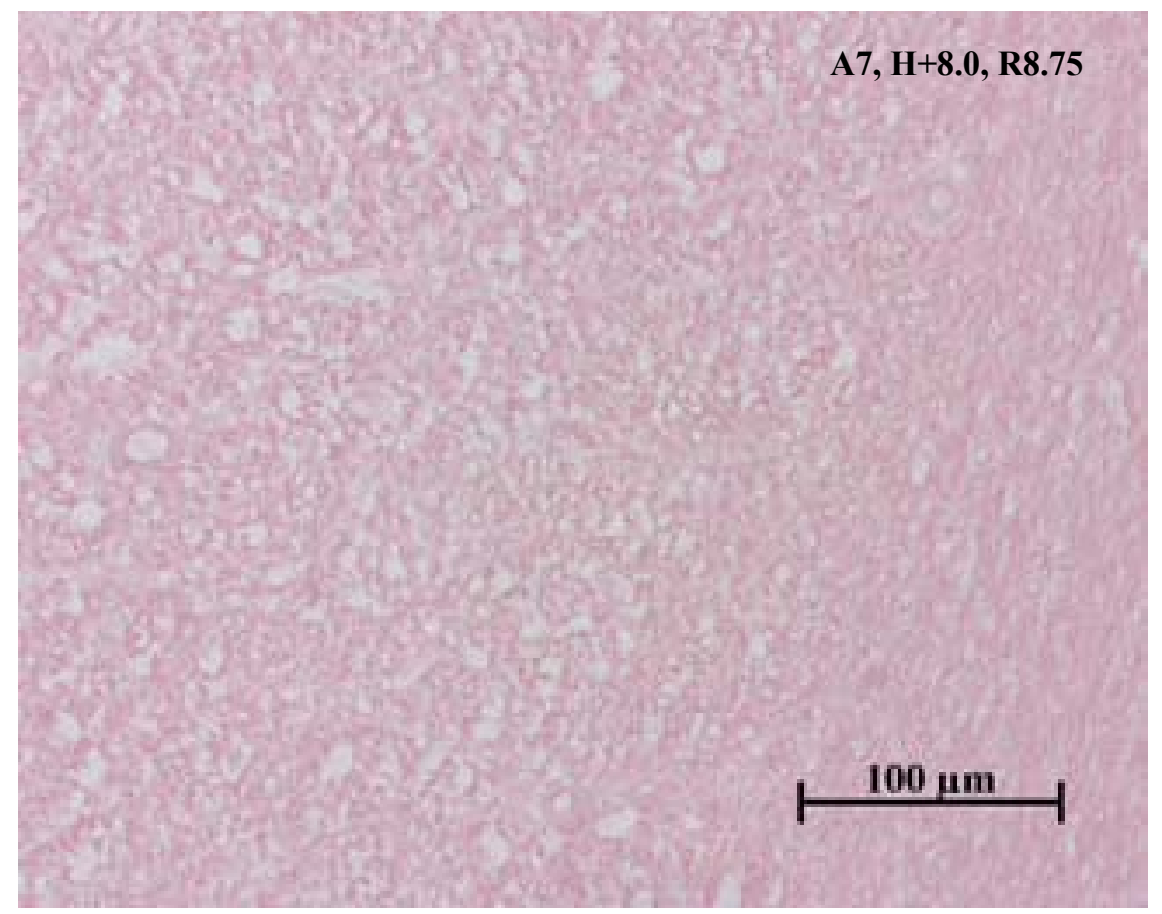

Abb.23.4: $\quad$ ISH der dig-IL-1ra-Sense-Sonde (violett, NBT/BCIP) in der Claustrumregion mit Kernechtrot (rot) gegengefärbt. C. jacchus, Männchen (Gehirn 3, Schnitt 1414) 200x

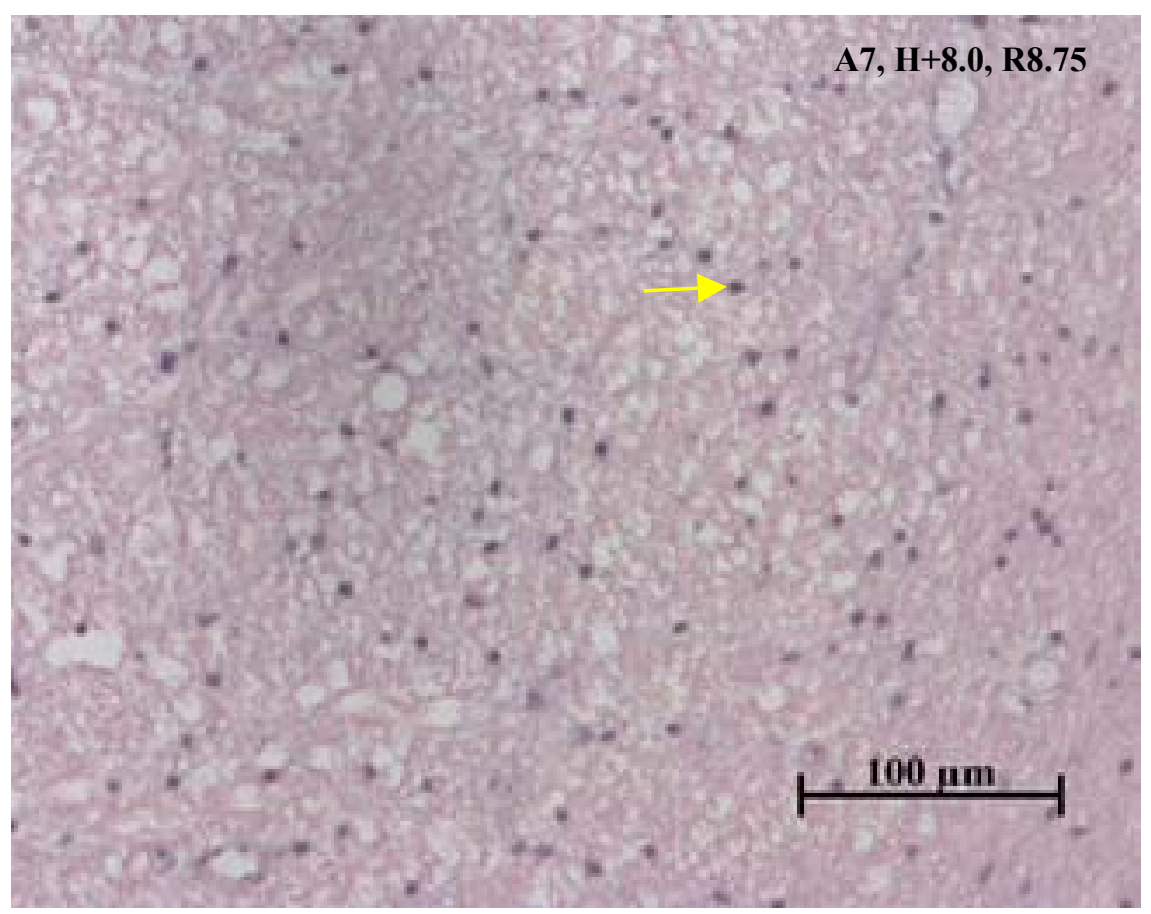

Abb.23.5: $\quad$ Positive ISH-Signale ( gelber Pfeil) der dig-IL-1ra-Antisense-Sonde (violett, NBT/BCIP) in der Claustrumregion mit Kernechtrot (rot) gegengefärbt. C. jacchus, Männchen (Gehirn 3, Schnitt 1413) 200x 


\subsubsection{Interleukin-1 Rezeptor Typ I (IL-1RI)}

Im Cortex konnte mit Hilfe der ISH ein schwacher Nachweis einer mRNA Expression von IL-1RI erbracht werden. In der IHC waren jedoch deutlich positive Neuronen zu identifizieren. Auch im Striatum konnte eine mRNA Expression nachgewiesen werden, das Signal war aber im Vergleich zu dem Liganden und dem Rezeptor Antagonisten nicht so stark. Im Hippocampus wurden im Vergleich zu dem Liganden ebenfalls schwächere Signale gefunden, sowohl in der ISH, als auch in der IHC. Der Interleukin1 Rezeptor Typ I zeigte im Hippocampus sowohl eine Proteinexpression in den Neuronen der Arealen CA1-CA4 hippocampi, als auch eine Expression in der Fascia dentata In Abb.24.1 sind positive Signale der ISH in den Pyramidenzellen der Area CA4, sowie in der Fascia dentata zu erkennen.

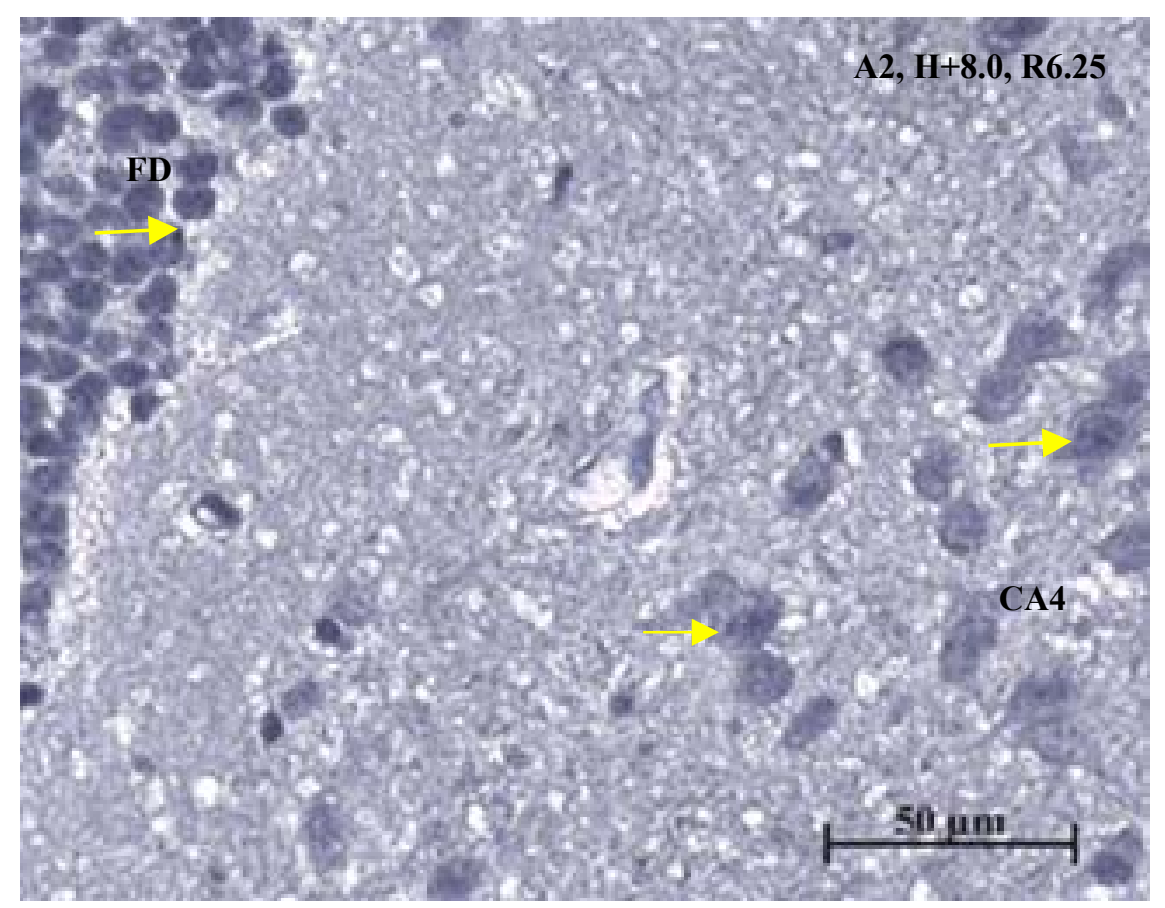

Abb.24.1: $\quad$ Positive ISH-Signale (Beispiele durch gelbe Pfeile gekennzeichnet) der biotin-IL-1RISonde (braun, DAB+) in der Fascia dentata (FD) und der Area CA4 hippocampi (CA4) des Hippocampus mit Hämatoxilin (blau) gegengefärbt. C. jacchus, Männchen (Gehirn 3, Schnitt 2496), 400x

Im Cortex wurden die Neuronen als Expressionsorte der mRNA und des Proteins identifiziert (Abb.24.2-24.4). 


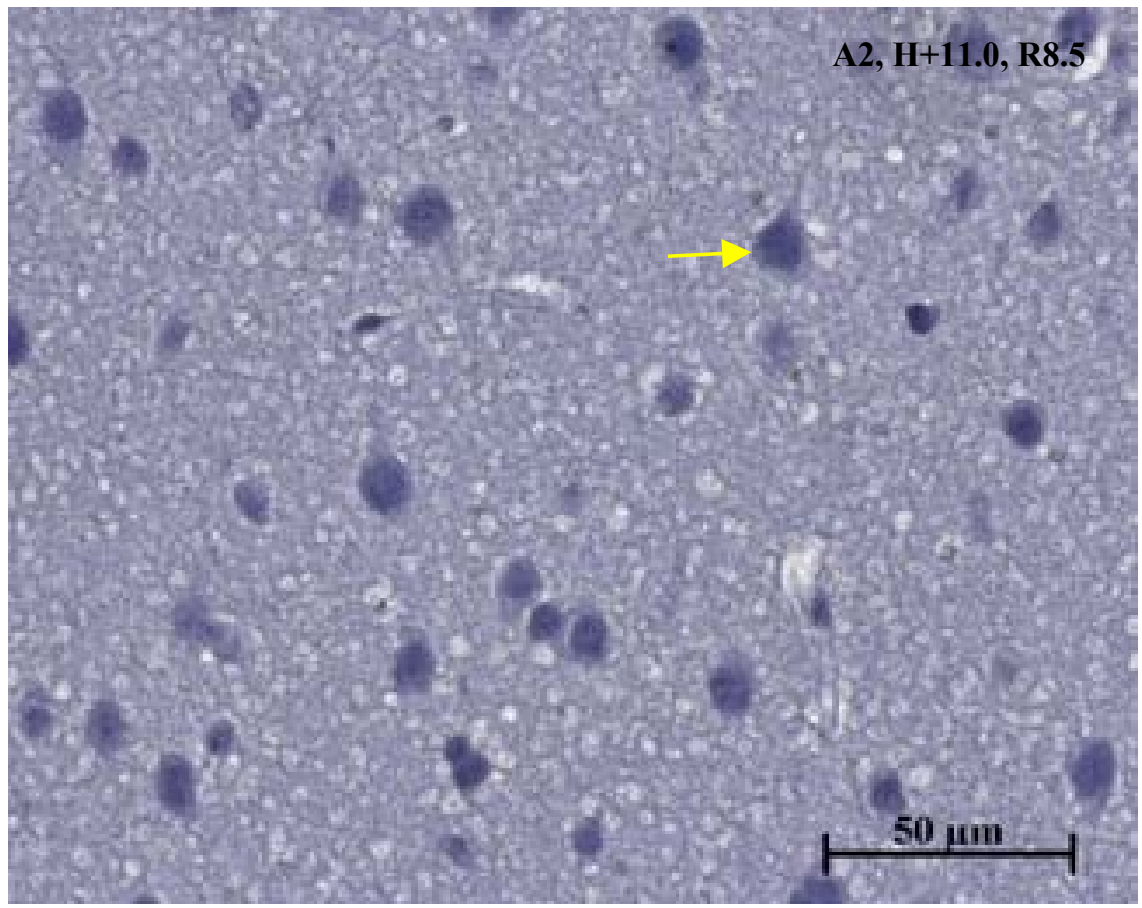

Abb.24.2: $\quad$ Positive ISH-Signale ( $\quad$ Pfeil) der biotin-IL-1RI-Sonde (braun, DAB+) im Cortex mit Hämatoxilin (blau) gegengefärbt. C. jacchus, Männchen (Gehirn 3, Schnitt 2496) 400x

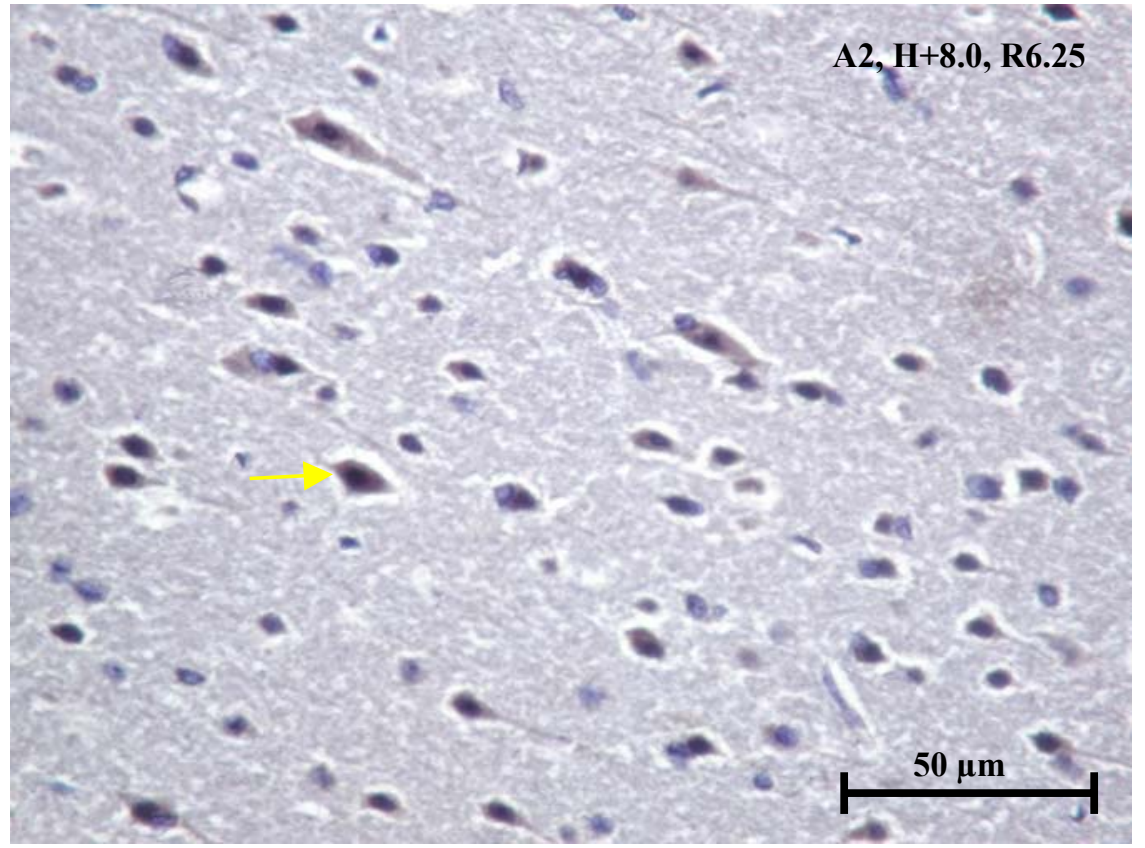

Abb.24.3: $\quad$ Positive IHC-Signale (gelber Pfeil) des IL-1RI-Antikörpers (braun, DAB+) im Cortex frontalis mit Hämatoxilin (blau) gegengefärbt. C. jacchus, Männchen (Gehirn 1, Schnitt 999) 400x 
Die mRNA von IL-1RI konnte im Claustrum (Abb.24.5) nachgewiesen werden. Abb.24.4 wies keine positiven Signal auf, es wurde die Sense Sonde verwendet.

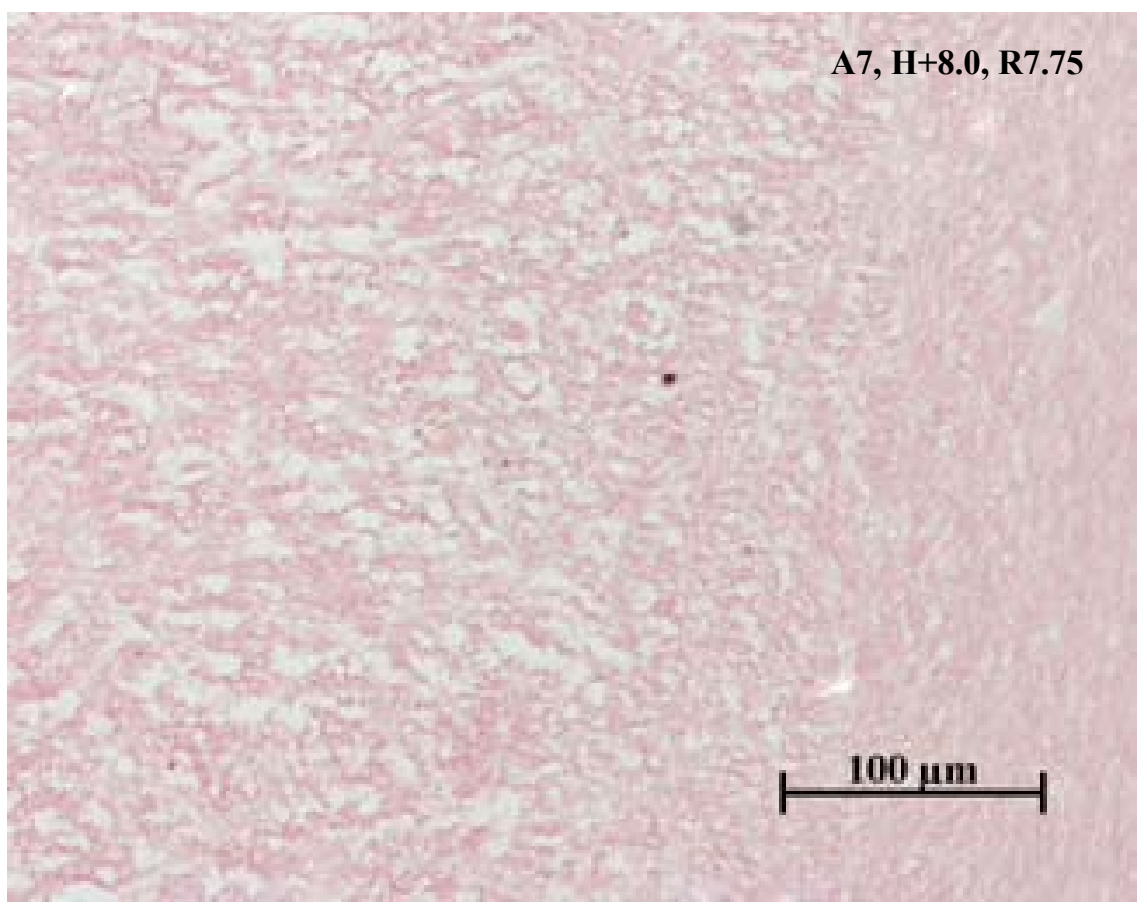

Abb.24.4: ISH der negativen dig-IL-1RI-Sense-Sonde (violett, NBT/BCIP) in der Claustrumregion mit Kernechtrot (rot) gegengefärbt. C. jacchus, Männchen (Gehirn 3, Schnitt 1416) 200x

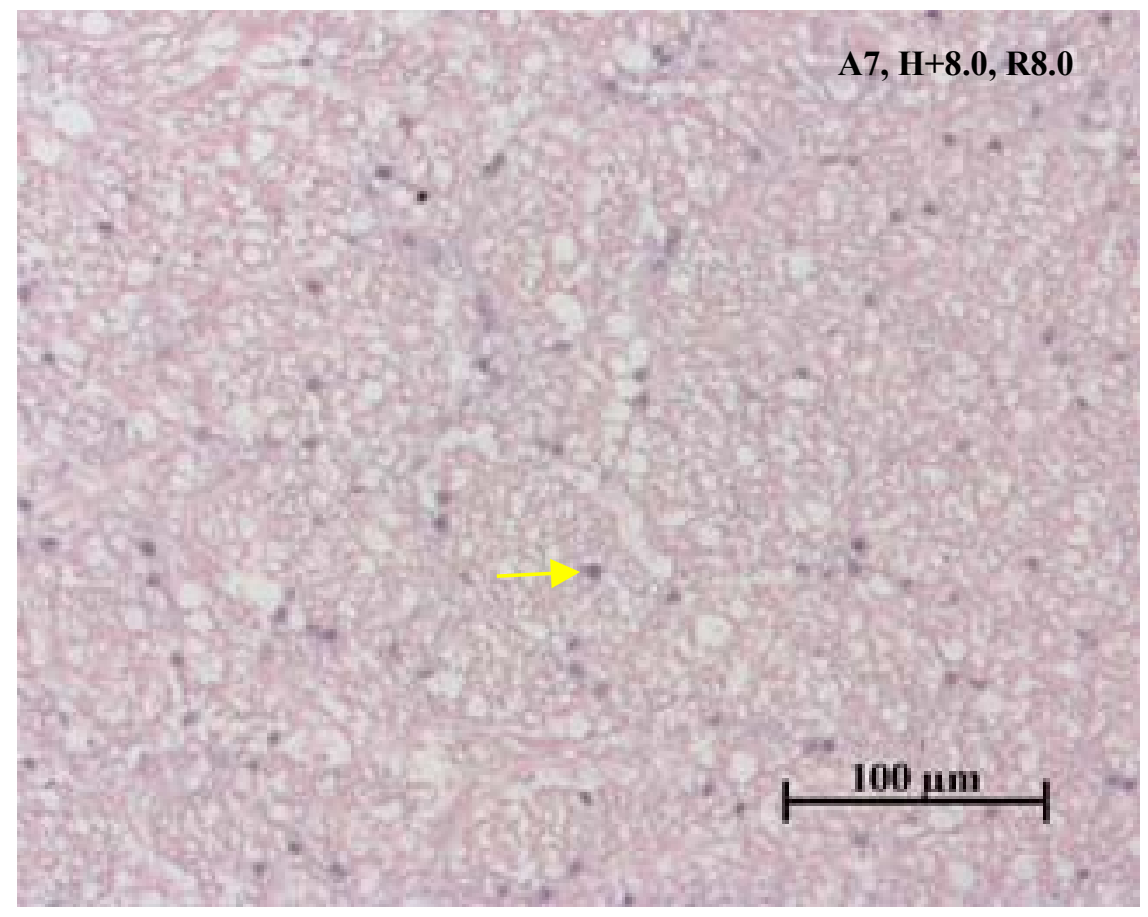

Abb.24.5: Positive ISH (gelber Pfeil) der dig-IL-1RI-Antisense-Sonde (violett, NBT/BCIP) in der Claustrumregion mit Kernechtrot (rot) gegengefärbt. C. jacchus, Männchen (Gehirn 3, Schnitt 1415) 200x 


\subsubsection{Interleukin-1 Rezeptor Typ II (IL-1RII)}

Wie auch die mRNA des Rezeptor Typ I konnte die mRNA des Rezeptor Typ II im Cortex nachgewiesen werden. Die IHC zeigte positive Neuronen im Cortex.

Im Striatum zeigte sich ein ähnliches Bild, wie auch beim Rezeptor Typ I. Die positiven Signale der ISH waren stärker als beim IL-1RI.

Auch im Hippocampus wurde eine mRNA Expression nachgewiesen. In der IHC wurden die großen Pyramidenzellen als positive Zellen identifiziert.

Auffallend war die im Vergleich zum Interleukin-1 Rezeptor Typ I viel stärkeren Signale, sowohl der In-situ-Hybridisierung, als auch der Immunhistologie.

Eine Expression des Rezeptor Typ II wurde im Hippocampus sowohl in den Neuronen der Area CA1-CA4 hippocampi gesehen, als auch in den Zellen der Fascia dentata (Abb.25.1-25.2). Parallel wurde auch das Protein in den selben Zellen vorgefunden (Abb.25.3).

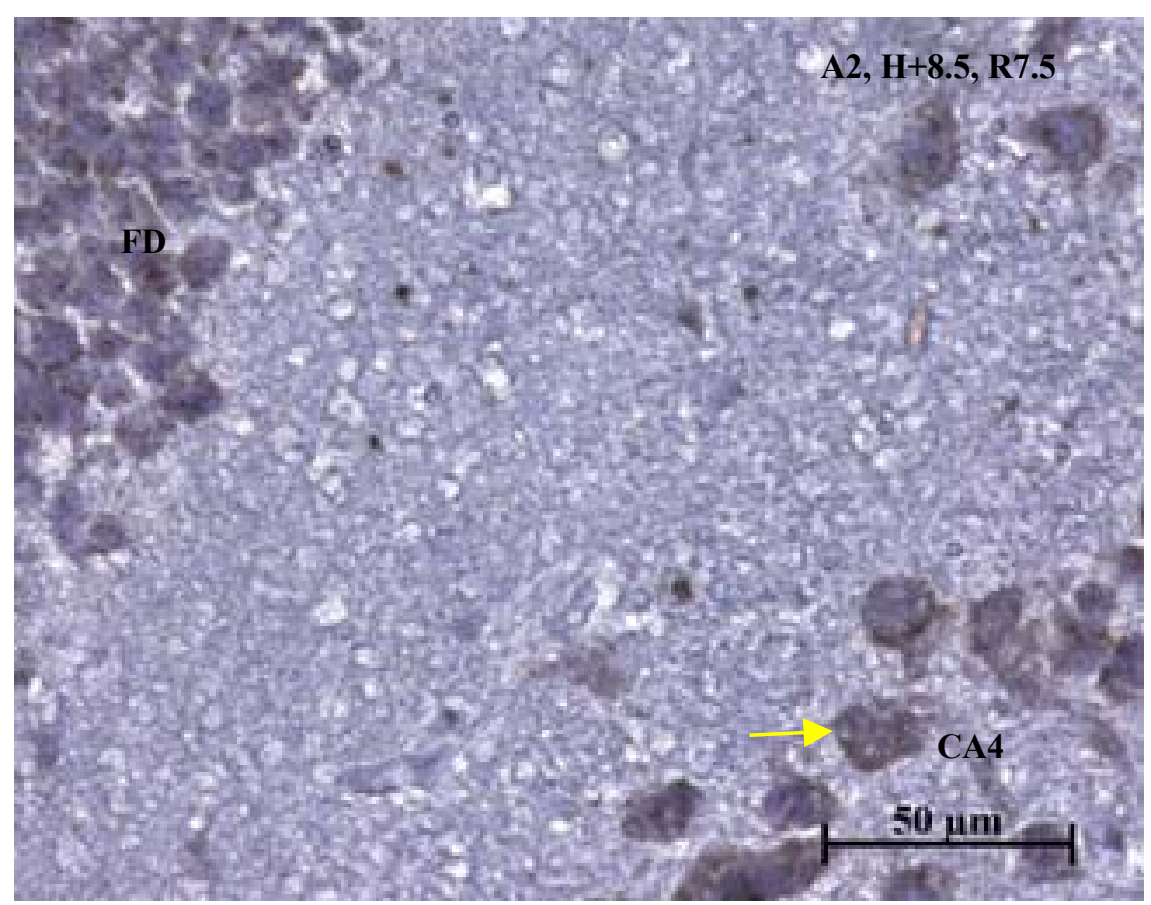

Abb.25.1: $\quad$ Positive ISH-Signale (Beispiel durch einen Pfeil gekennzeichnet) der biotin-IL1RII-Sonde (braun, $\mathrm{DAB}+$ ) in der Fascia dentata (FD) und der Area CA4 hippocampi (CA4) des Hippocampus mit Hämatoxilin (blau) gegengefärbt. C. jacchus, Männchen (Gehirn 3, Schnitt 2497), 400x 


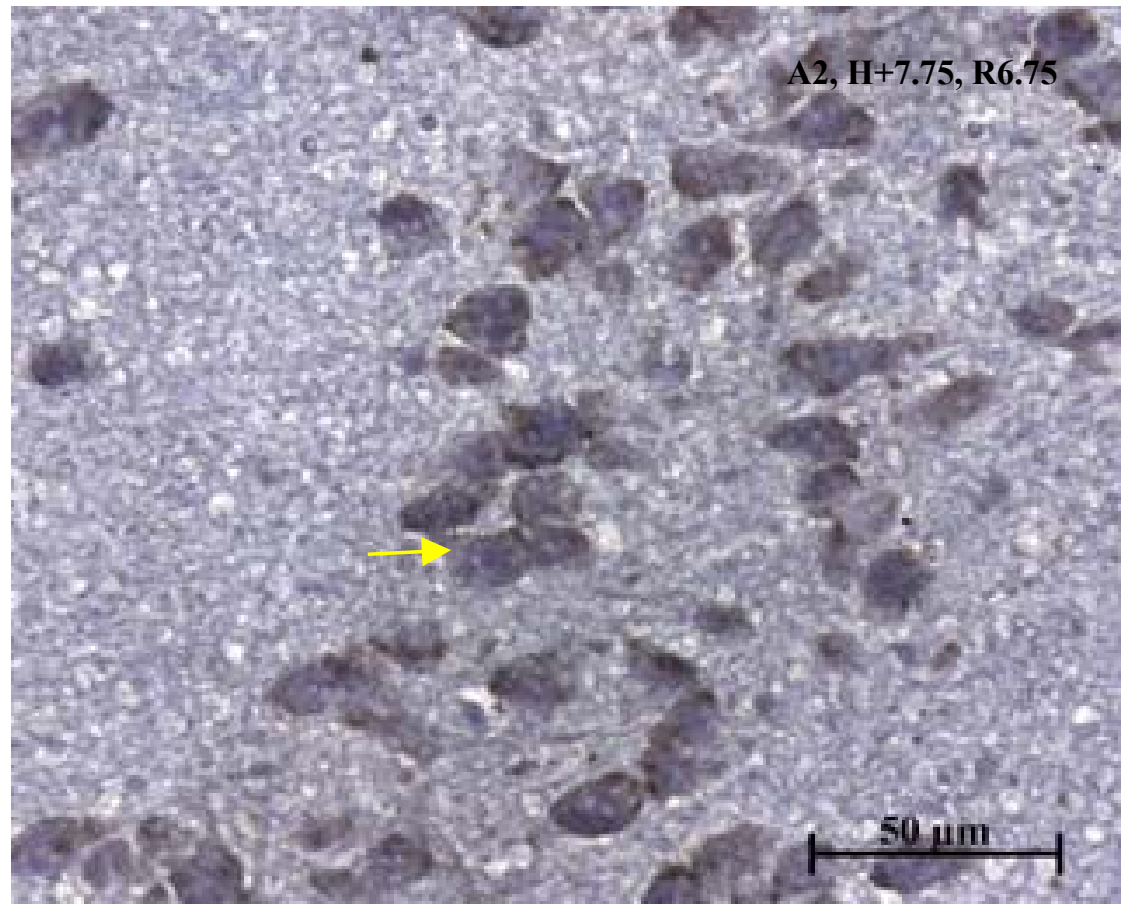

Abb.25.2: $\quad$ Positive ISH-Signale (gelber Pfeil) der biotin-IL-1RII-Sonde (braun, DAB+) in der Area CA3 hippocampi (CA3) des Hippocampus mit Hämatoxilin (blau) gegengefärbt. C. jacchus, Männchen (Gehirn 3, Schnitt 2497), 400x

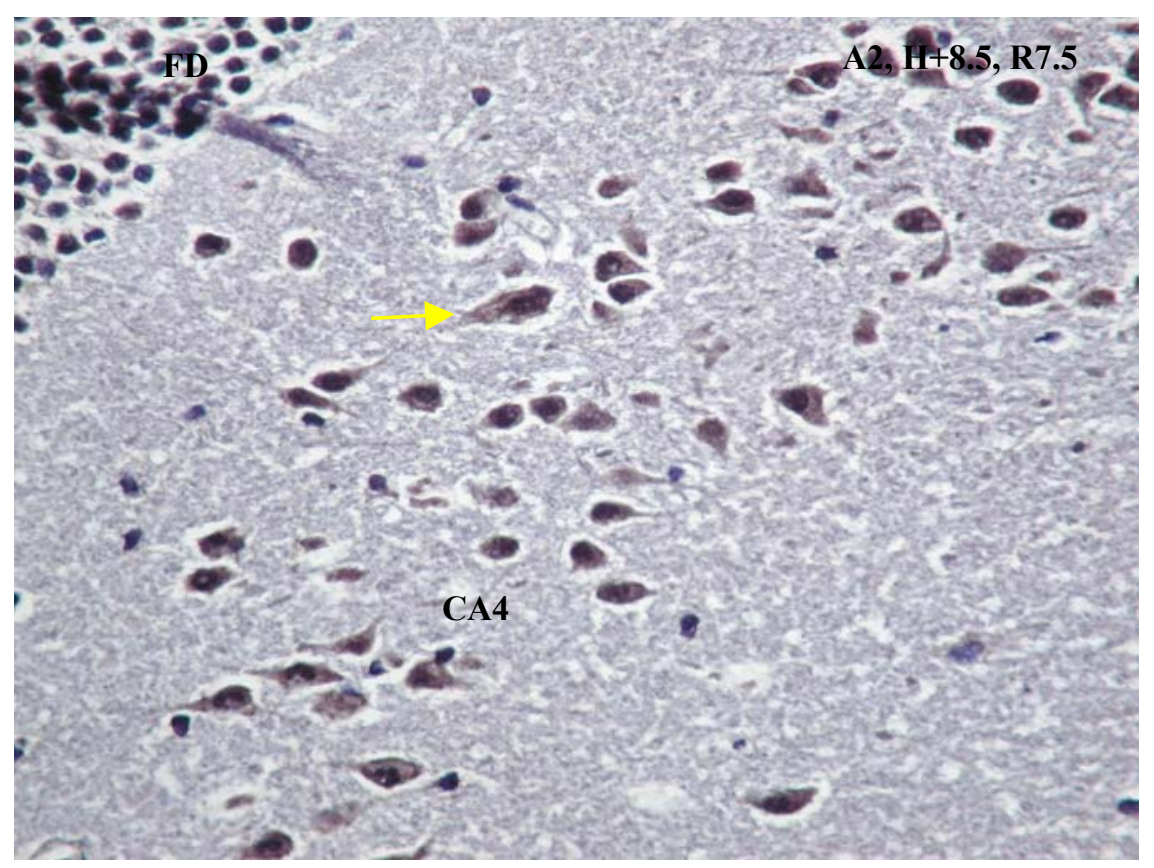

Abb.25.3: $\quad$ Positive IHC-Signale ( $\quad$ Pfeile) des IL-1RII-Antikörpers (braun, DAB+) in der Fascia dentata (FD) und der Area CA4 hippocampi (CA4) des Hippocampus mit Hämatoxilin (blau) gegengefärbt. C. jacchus, Männchen (Gehirn 3, Schnitt 2504), 200x Im Cortex exprimieren Neuronen IL-1RI (Abb.25.4). 


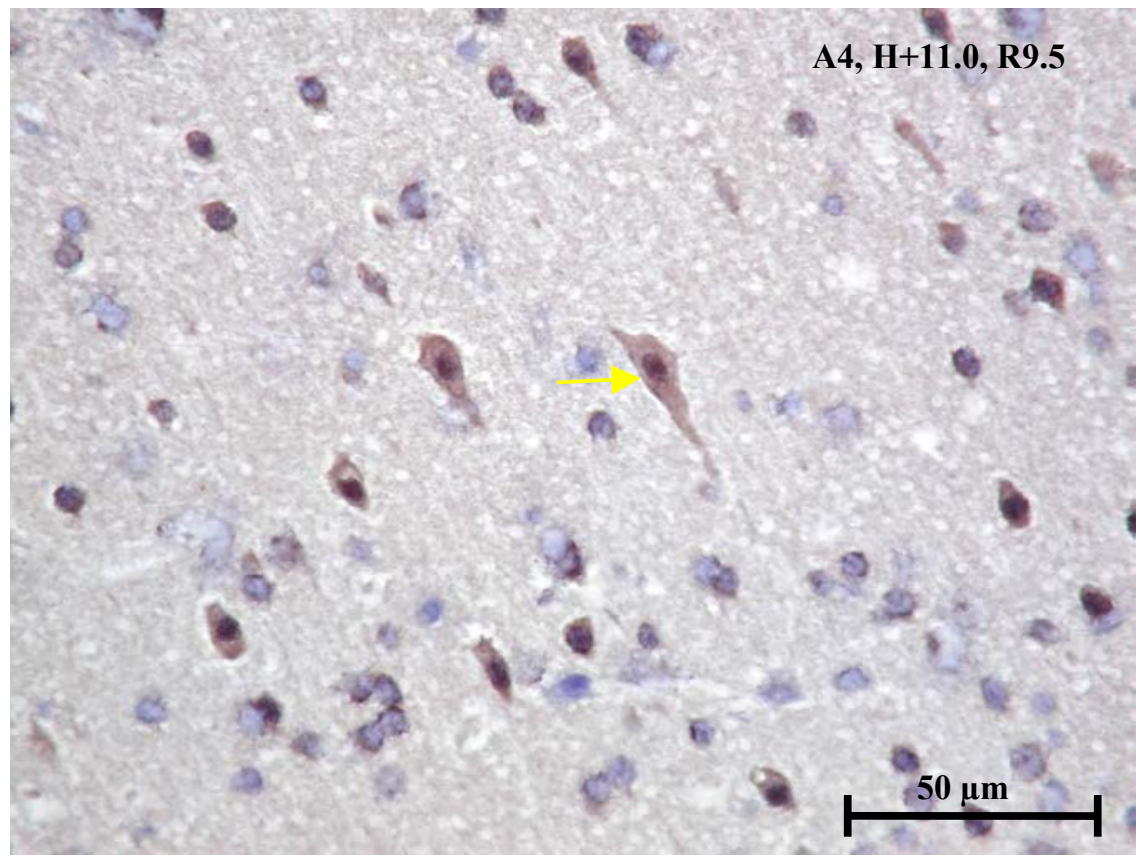

Abb.25.4: $\quad$ Positive IHC-Signale ( $\quad$ Pfeil) des IL-1RII-Antikörpers (braun, DAB+) im Cortex mit Hämatoxilin (blau) gegengefärbt. C. jacchus, Männchen (Gehirn 1, Schnitt 3369), 200x

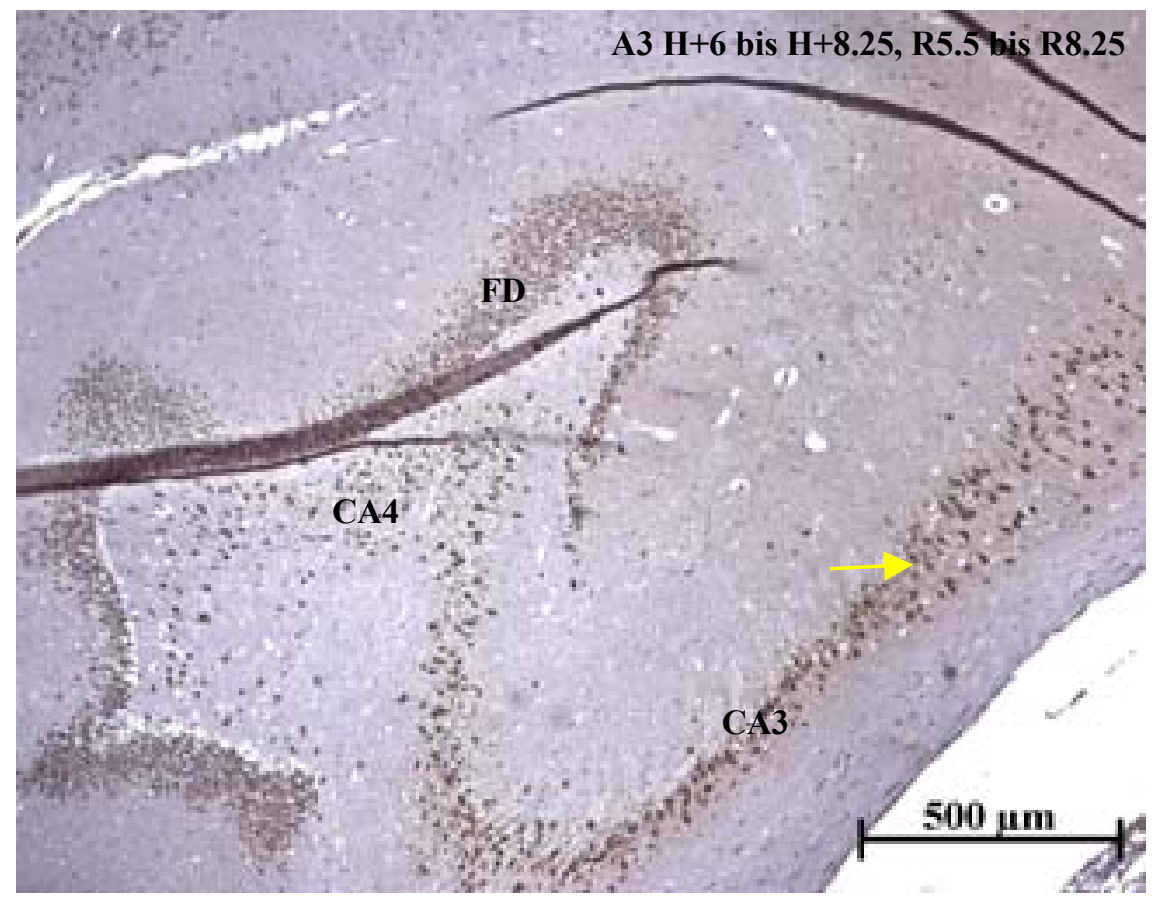

Abb.25.5: $\quad$ Positive IHC-Signale (gelber Pfeil) des IL-1RII-Antikörpers (braun, DAB+) im Cortex mit Hämatoxilin (blau) gegengefärbt. C. jacchus, Männchen (Gehirn 1, Schnitt 2892), 40x

Abb.25.5 zeigt noch einmal die Hippocampusregion in einer Übersichtsaufnahme mit den sehr deutlich positiven Signalen der biotin-Sonden. 


\subsubsection{Glia oder Neuron?}

Unter Punkt 3.2.5 wurde die Expression mittels ISH und IHC beschrieben und nachgewiesen. Die Definition, ob es sich um eine Neuron- oder Gliazelle handelte, wurde zunächst aufgrund der morphologischen Struktur getroffen. Im Folgenden wurde ein Versuch zur Klärung, welcher Zelltyp IL-1 $\beta$ und IL-1ra expremiert, mittels Doppelfärbung durchgeführt. Hierbei wurde zunächst die mRNA-Expression mit digSonden nachgewiesen und anschließend eine IHC entweder mit dem GFAP- oder dem NSE-Antikörper durchgeführt.

In Abb. 26.1 zeigte sich eine spezifische Verteilung von Astrogliazellen in einer bestimmten Gebiet des frontalen Cortex. Positive mRNA-Signalen von IL-1 $\beta$ wurden aber auch deutlich außerhalb dieses Gebietes gefunden

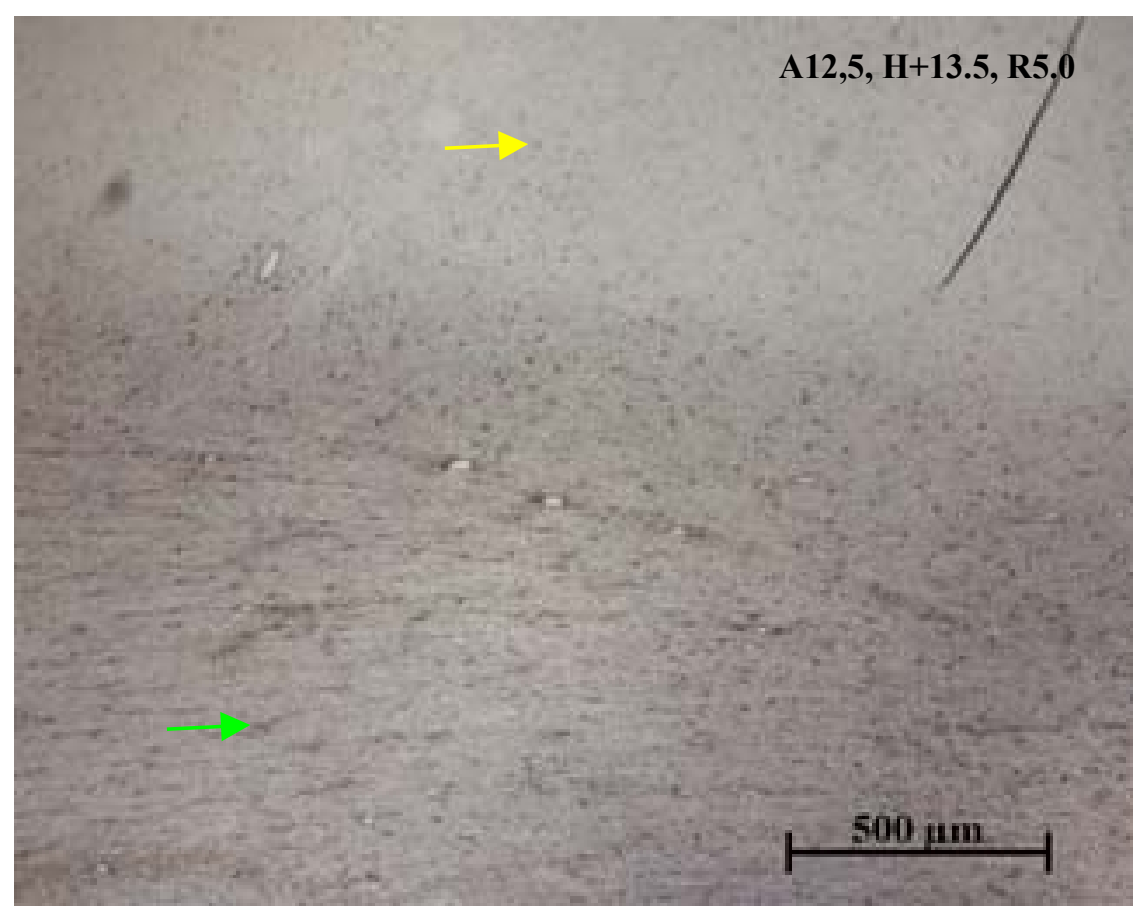

Abb.26.1: $\quad$ Positive ISH-Signale (Beispiel durch einen gelben Pfeil gekennzeichnet) der dig-IL-1 $\beta$ Antisense-Sonde (violett, NBT/BCIP) und positive IHC-Signale (Beispiel durch einen grünen Pfeil gekennzeichnet) des GFAP-Antikörpers (braun, DAB+) im Cortex frontalis. C. jacchus, Männchen (Gehirn 3, Schnitt 371) 40x

Bei 400facher Vergrößerung (Abb.26.2) ist zu erkennen, die positiven ISH-Signale der dig-Antisense-IL-1 $\beta$-Sonde nicht mit den positiven IHC-Signalen des GFAPAntikörpers deckungsgleich sind. 


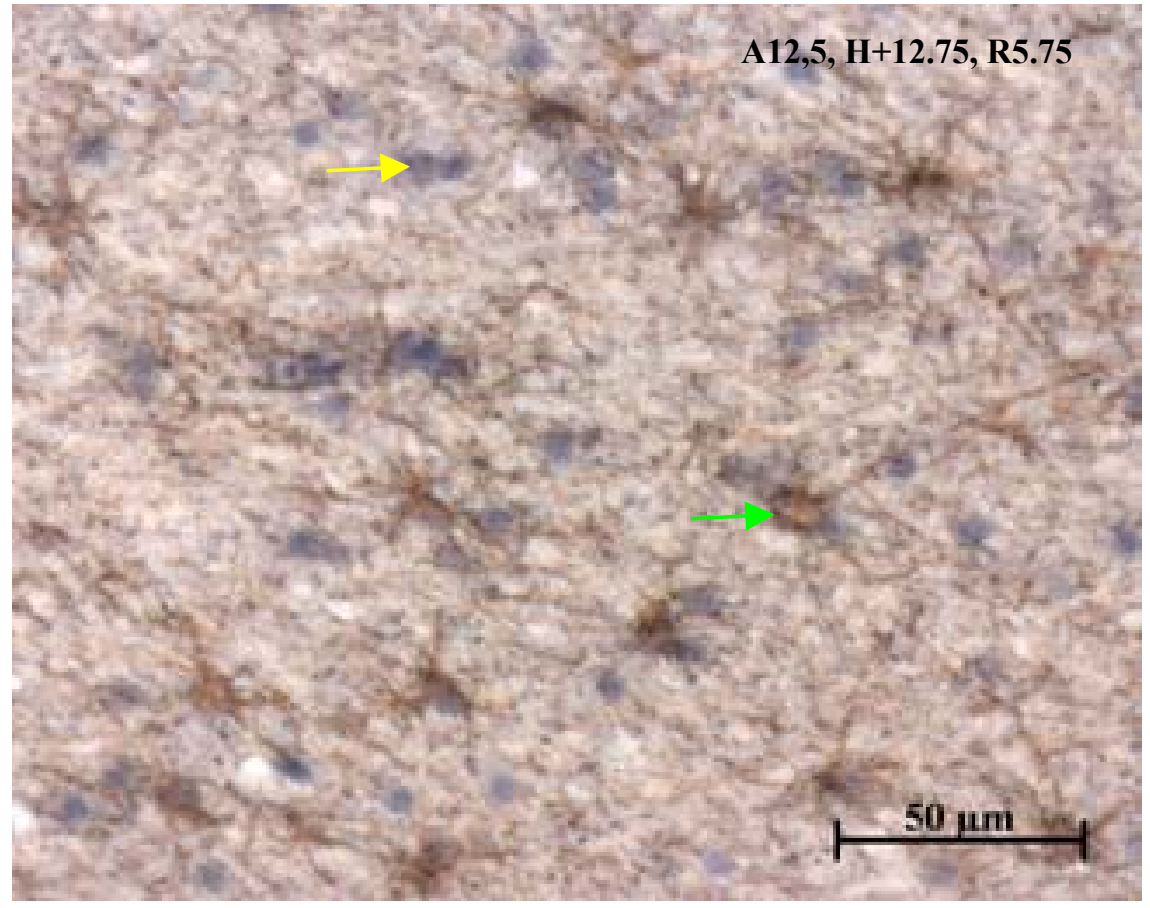

Abb.26.2: $\quad$ Positive ISH-Signale ( $\quad$ Pel leil) der dig-IL-1 $\beta$-Antisense-Sonde (violett, NBT/BCIP) und positive IHC-Signale (grüner Pfeil) des GFAP-Antikörpers (braun, DAB+) im Cortex frontalis. C. jacchus, Männchen (Gehirn 3, Schnitt 371) 400x

Bei einer Färbung im Cortexbereich mit der dig-IL-1 $\beta$-Antisense-Sonde und dem NSEAntikörper zeigten sich Neuronen positiv für die mRNA-IL-1 $\beta$ Expression.

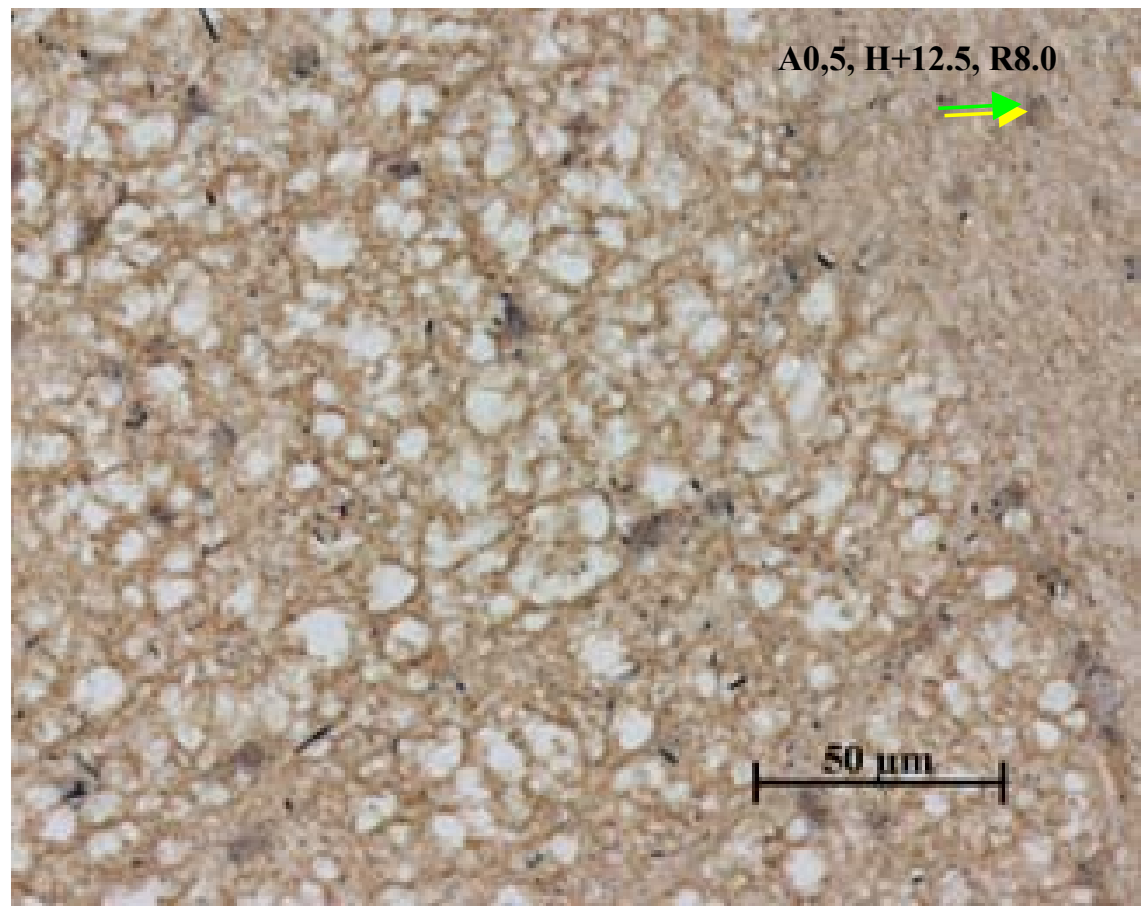

Abb.26.3: Positive ISH-Signale (gelber Pfeile) der dig-IL-1 $\beta$-Antisense-Sonde (violett, NBT/BCIP) und positive IHC-Signale (grünr Pfeile) des NSE-Antikörpers (braun, DAB+) im Cortex. C. jacchus, Männchen (Gehirn 3, Schnitt 2732) 400x 
Die Ergebnisse der Doppelfärbung zeigten für IL-1ra ebenfalls eine Expression in Neuronen.

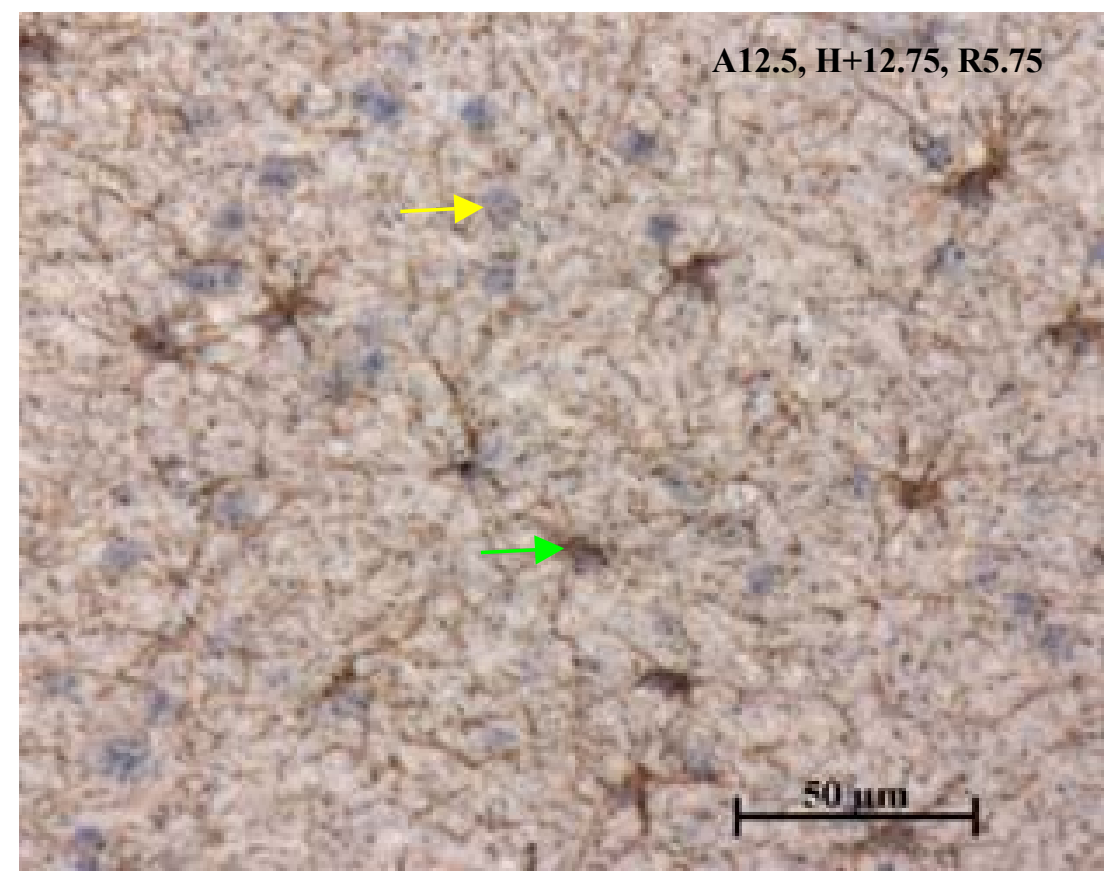

Abb.26.4: Positive ISH-Signale (gelber Pfeil) der dig-IL-1ra-Antisense-Sonde (violett, NBT/BCIP) und positive IHC-Signale (grüner Pfeil) des GFAP-Antikörpers (braun, $\mathrm{DAB}+$ ) im Cortex frontalis. C. jacchus, Männchen (Gehirn 3, Schnitt 372) 400x

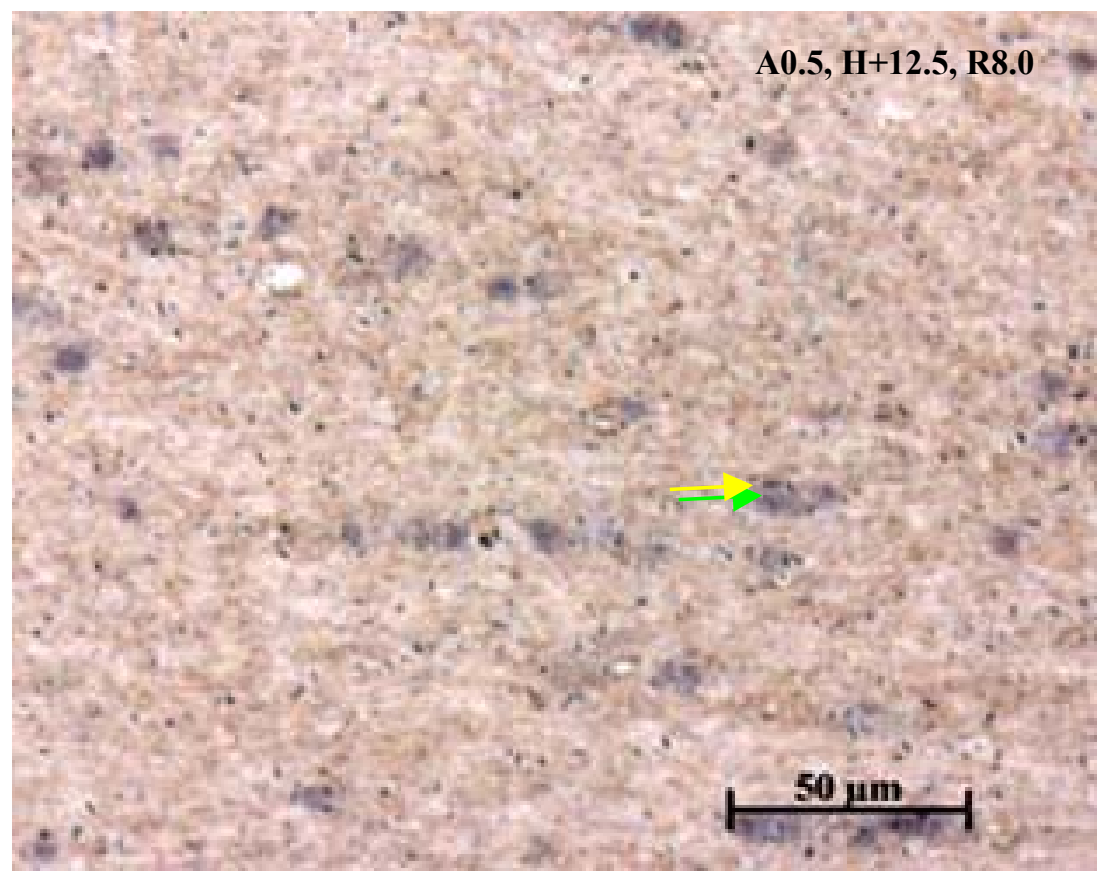

Abb.26.5: Positive ISH-Signale (gelber Pfeil) der dig-IL-1ra-Antisense-Sonde (violett, NBT/BCIP) und positive IHC-Signale (grüner Pfeil) des NSE-Antikörpers (braun, DAB+) im Cortex frontalis. C. jacchus, Männchen (Gehirn 3, Schnitt 2733) 400x 


\subsubsection{Verteilung der positiven Signale der ISH}

Die Verteilung der positiven Signale der Sonden in der in-situ-Hybridisierung wurde in schematischen Zeichnungen des Hirnschnittes festgehalten und mit Hilfe der selbst erstellten Karten den einzelnen Hirnbereichen zugeordnet. In Abb.27 sind Beispiele für IL-1 $\beta$, IL-1ra, IL-1RI und IL-1RII angegeben.

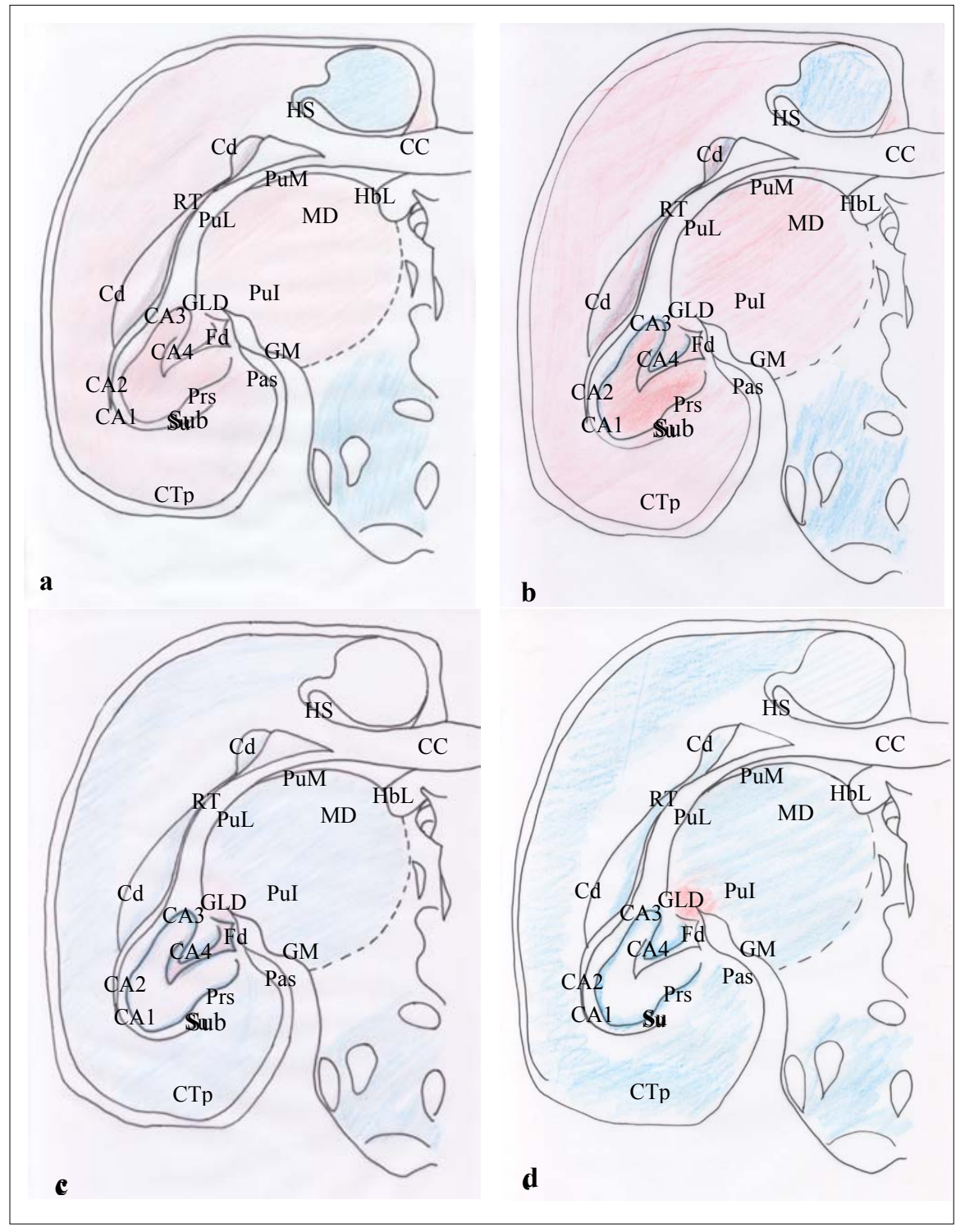

Abb.27: Expressionsverteilung der In-situ-Hybridisierung von IL-1 $\beta$ (a), IL-1ra (b), IL-1RI (c) und IL1RII (d) auf die einzelnen Hirnregionen; rot: positive Glia; blau: positive Neuronen

CA1: Area CA1 hippocampi, CA2: Area CA2 hippocampi, CA3: Area CA3 hippocampi, CA4: Area CA4 hippocampi, CC: Corporus callosum, Cd: Nucleus caudatus, CTp: Cortex temporalis, Fd: Fascia dentata, GLD: Corpus geniculatum laterale dorsale, HbL: Nucleus habenularis medialis, HS: Hippocampus praecommis-suralis, MD: Nucleus medialis dorsalis thalami, Pas: Regio parasubicularis, Prs: Regio praesubicularis, PuI: Pulvinar inferior, PuL: Pulvinar lateralis, PuM: Pulvinar medialis, RT: Nucleus reticularis thalami, Sub: Subiculum (hippocampi) 


\title{
3.3 RT-PCR
}

Mit der ISH gelang ein Nachweis von IL-1, IL-1ra, IL-1RI und IL-1RII im Gehirn von C. jacchus. Für eine zuverlässige Quantifizierung war diese Methode jedoch nicht geeignet. Es wurde eine RT-PCR durchgeführt. Diese Methode ist sensibler als die ISH und ermöglicht eine zuverlässige Quantifizierung.

Unter Punkt 2.6.1 wurden Methoden zum Nachweis von IL-1 $\beta$ und IL-1ra mRNA im Gehirn von $C$. jacchus entwickelt.

Folgende Primer/Sonden-Systeme wurden hergestellt.

Sequenz mit Primer und Sonde für IL-1 $\beta$

5‘GGCATCCAGCTGCGACTCCTCcegecggcactacagcaagggettCAGGCAGGTTGTGTCGGTTGT CGTGGCTA3“

Sequenz mit Primer und Sonde für IL-1ra

5'AGTTGACATCACTGACCTTGAGCAAGAACAAAAAGCAGGACGAGCGTTTCaccttcatccg ctcagacagcggcCCCACGACCAGTTTCGAGTCTGCTGCCTGCC3 ‘

\author{
Abb.28: Sequenzen für den TaqMan \\ rot: sense Primer, blau: antisense Primer, grün: Sonde
}

Für den Vergleich der mRNA Expression wurde der Durchschnitt der Meßwerte der jeweiligen Kontrollgruppe gleich 100\% gesetzt und die Werte der LPS-behandelten Gruppe dazu ins Verhältnis gesetzt. Die statistische Auswertung erfolgte jeweils mit einem zweiseitigem t-Test. Die Signifikanzen mit eine P-Wert $\leq 0.05$ wurden durch ein Sternchen (*) gekennzeichnet.

Dieses Verfahren wurde auch für alle weiteren Expressionsdaten, die im Folgenden dargestellt sind, angewendet. 


\subsubsection{IL-1 $\beta$ und IL-1ra mRNA im Claustrum}

Aufgrund der vorliegenden Daten ist ein stimulierender Effekt der LPS-Behandlung auf die IL-1 $\beta$ mRNA Expression im Claustrum offensichtlich. Die statistische Auswertung mit dem zweiseitigen t-Test ergab eine Signifikanz mit einem P-Wert von 0.0144. Die IL-1ra mRNA Expression der LPS-behandelten Gruppe zeigte dagegen jedoch keinen signifikanten Unterschied (P-Wert 0.7363) im Vergleich zur Kontrollgruppe.

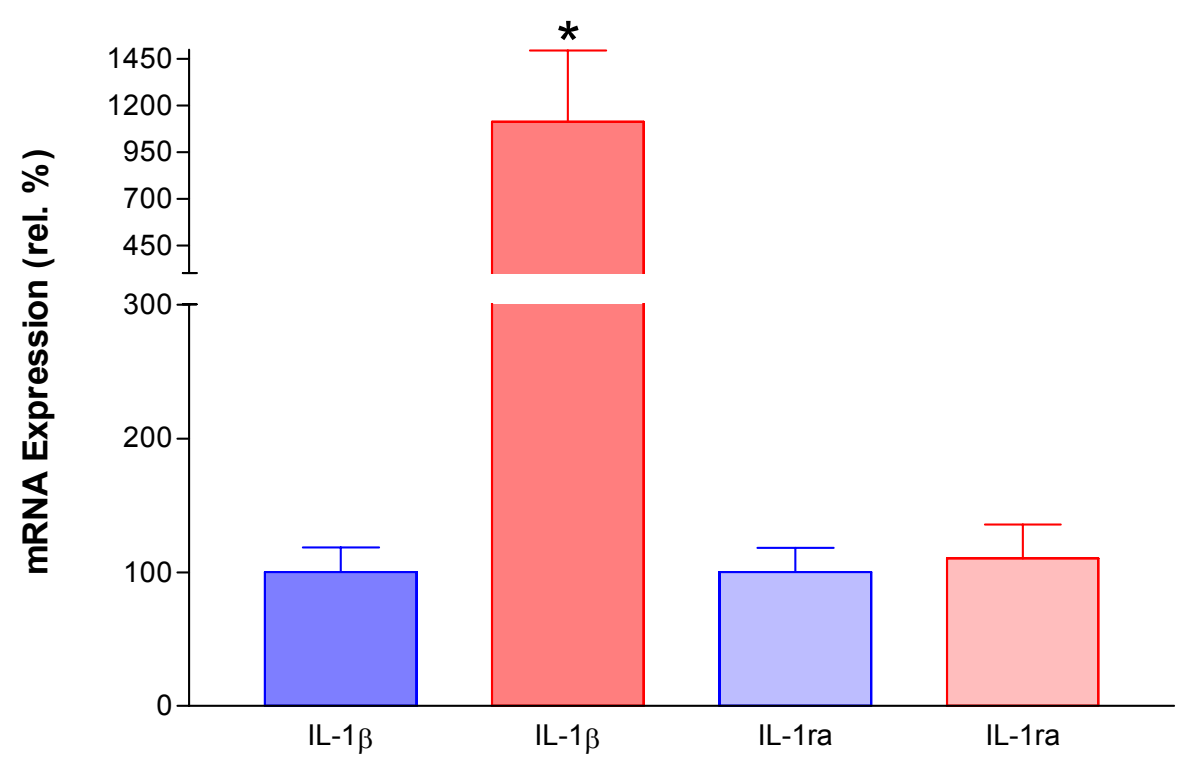

Abb.29: IL-1 $\beta$ und IL.1ra mRNA Expressionen als Mittelwerte mit SEM der Kontroll-(n=7) und LPSbehandelten $(n=6)$ Gruppen in der Claustrumstanze; * kennzeichnet eine Signifikanz von $\leq 0.05$. 


\subsubsection{IL-1 $\beta$ und IL-1ra mRNA Expression im Cortex}

Die Expression von IL-1 $\beta$ in der LPS-behandelten Gruppe lagen um ein vielfaches höher als in der Kontrollgruppe. Aufgrund der Signifikanz (P-Wert von <0.001), die mittels des t-Tests ermittelt wurde, liegt ein stimulierender Effekt der LPS-Behandlung vor.

Beim Vergleich der IL-ra mRNA Expression im Cortex ließ sich eine höhere Expression gegenüber der Kontrollgruppe beobachten. Die statistische Auswertung ergab keine Signifikanz. Der P-Wert lag bei 0.122 .

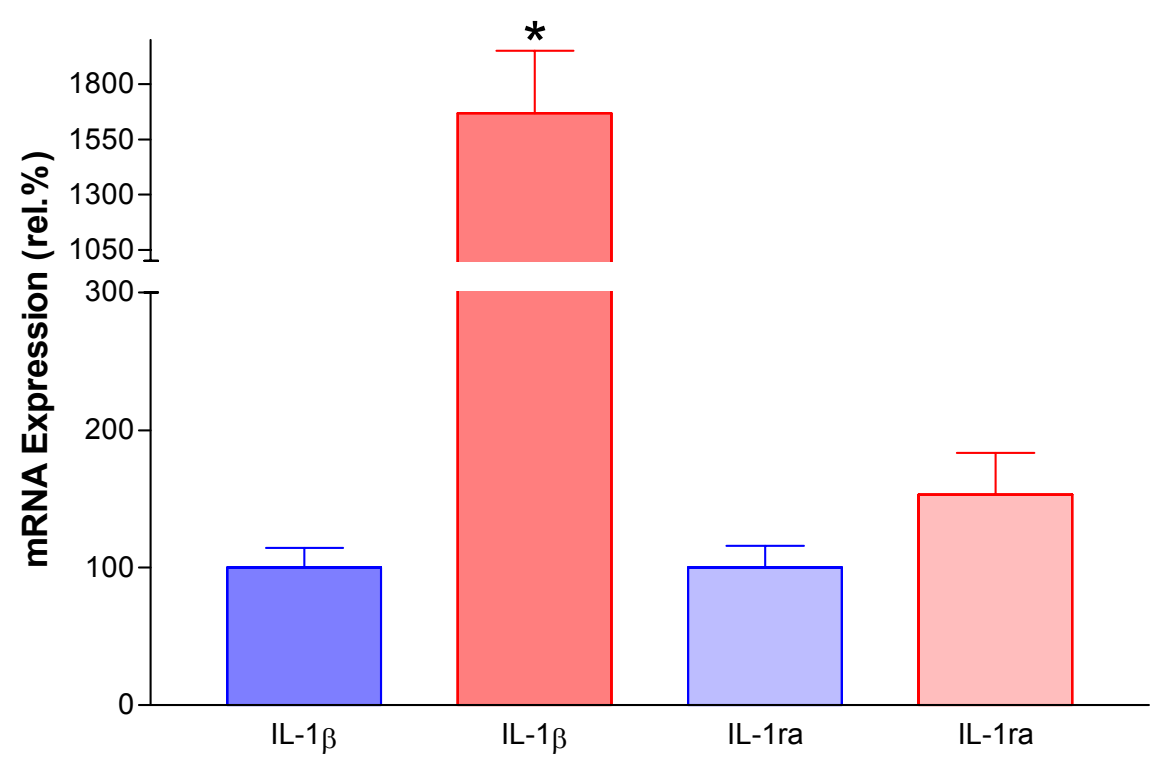

Abb.30:IL-1 $\beta$ und IL.1ra mRNA Expressionen als Mittelwerte und SEM der Kontroll-(n=7) und LPSbehandelten ( $\mathrm{n}=6$ bzw. $\mathrm{n}=5$ ) Gruppen in der Cortexstanze; * kennzeichnet eine Signifikanz von $\leq 0.05$. 


\subsubsection{IL-1 $\beta$ und IL-1ra mRNA Expression im Hippocampus}

Bei der Auswertung der mRNA-Expression für IL-1 $\beta$ in allen Hippocampusstanzen ergaben sich $\sim 14$ fach höhere Werte für die LPS-behandelte Gruppe als für die Kontrollgruppe. Der t-Test zeigte eine Signifikanz mit einem P-Wert von 0.0015. Auch hier war ein stimulierender Effekt der LPS-Behandlung zu beobachten.

Die IL-1ra Expression hingegen weist keinen signifikanten Unterschied (P-Wert von 0.465) im Vergleich der beiden Gruppen miteinander auf.

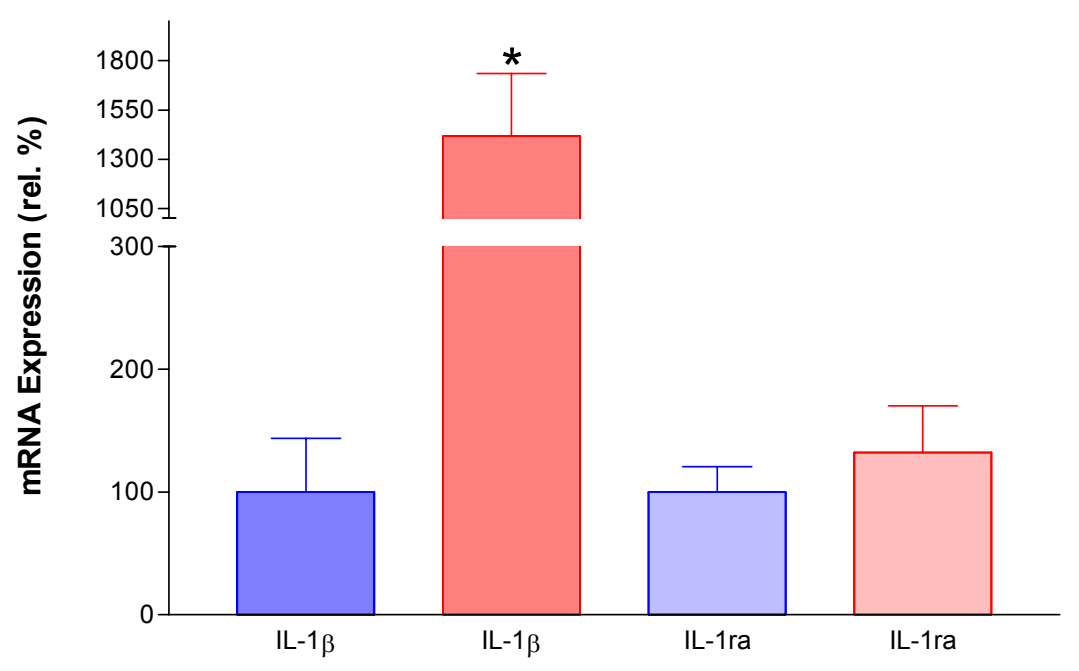

Abb.31:IL-1 $\beta$ und IL.1ra mRNA Expressionen als Mittelwerte und SEM der Kontroll-( $\mathrm{n}=7)$ und LPSbehandelten ( $\mathrm{n}=7$ ) Gruppen in der Hippocampusstanze; * kennzeichnet eine Signifikanz von $\leq 0.05$. 


\subsubsection{IL-1 $\beta$ mRNA Expression der Kontrollgruppe}

Beim Vergleich der Expression von IL-1 $\beta$ in den verschiedenen Hirnstanzen der Kontrollgruppe zeigte sich kaum ein Unterschied zwischen dem Expressionsniveau in der Hippocampus- und der Cortexsstanze. In der Claustrumstanze war die Expression höher als in den beiden anderen Stanzen.

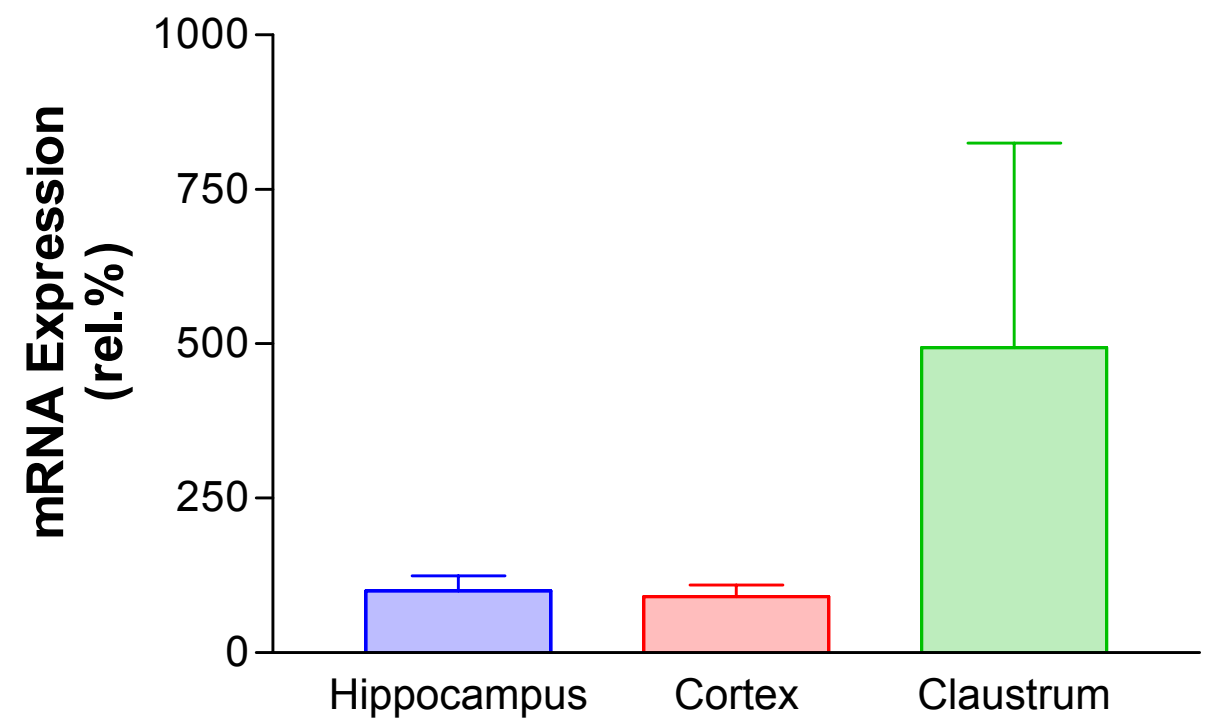

Abb.32: IL-1 $\beta$ mRNA Expressionen als Mittelwerte und SEM der Kontrollgruppe (n=7); * kennzeichnet eine Signifikanz von $\leq 0.05$. 


\subsubsection{IL-1ra mRNA Expression der Kontrollgruppe}

Bei einem Vergleich der Expression von IL-1ra zeigte sich die geringste Expression im Hippocampus. Im Cortex wurde fast doppelt so viel gemessen und im Claustrum wurde die höchste Expression bestimmt.

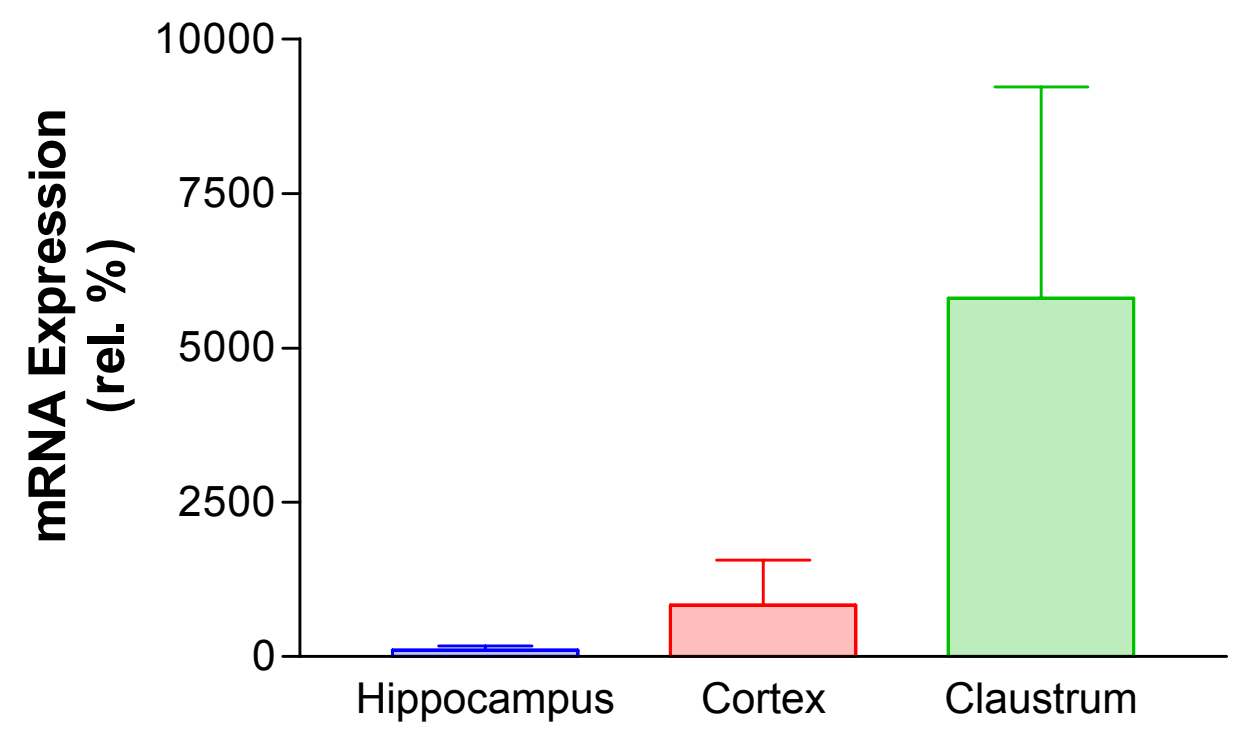

Abb.33: IL-1ra mRNA Expressionen als Mittelwerte und SEM der Kontrollgruppe(n=7); * kennzeichnet eine Signifikanz von $\leq 0.05$. 


\section{Diskussion}

\subsection{Cytokin- und Hormonspiegel}

Über die Wirkungen von Streß auf das Immunsystem und den Hormonhaushalt gibt es zahlreiche Untersuchungen zumeist bei Nagern. Einige beschäftigen sich mit Primaten, zumeist Rhesus- und Papio-Affen. Gerade Primaten eignen sich aufgrund ihrer dem Menschen ähnlichen Physiologie besonders gut als Tiermodelle. Es gibt bisher keine bekannten Untersuchungen über die Auswirkung von LPS-stimulierter Immunabwehr in Callithrix jacchus. Diese Untersuchungen sind somit neu und stellen einen wichtigen Beitrag zur Entwicklung eines neuen Tiermodells dar.

Um die Auswirkungen der Streßinduzierung (LPS) in der Peripherie zu beobachten, wurden die wichtigsten inflammatorischen Cytokine, IL-1 $\beta$ und TNF- $\alpha$, sowie die sogenannten Streßhormone Cortisol und Prolaktin im Serum der Primaten gemessen. Störungen im Immunsystem, wie sie Streß verursacht, gehen oft mit Änderungen im Bereich der Reproduktionshormone einher. Deswegen wurde auch das Hormon Testosteron bestimmt.

Im folgenden wird der Zusammenhang der LPS-induzierten Streßantwort des Immunsystems und die Auswirkungen davon auf die Hormone näher erläutert.

\subsubsection{Die Cytokine IL-1 $\beta$ und TNF- $\alpha$}

Die Auswertung der beiden Cytokinassays ergab eine signifikant Erhöhung sowohl von IL-1 $\beta$, als auch von TNF- $\alpha$ nach LPS-Stimulierung. Eine LPS-Stimulierung dieser Cytokine und deren Anstieg im Serum ist in mehreren Studien belegt worden, wie z.B. an Nagern (Goldman 1991), Kühen (Werling et al 1996) und Schweinen (Webel et al. 1997). Besonders stark stimuliert LPS die Cytokine TNF- $\alpha$, IL-1 und IL-6.

Ein Grund für den Anstieg dieser Cytokine im Blut ist ihre Synthese und die Freisetzung in B-Lymphozyten, Monozyten und Makrophagen. Die Aktivierung von IL$1 \beta$ und TNF- $\alpha$ ist abhängig von der Dosis und der Zeit, wie ein Versuch von Johnson und Mitarbeitern (2002) an Ratten zeigte. Johnson et al. verwendeten $10 \mu \mathrm{g} / \mathrm{kg}$ 
Körpergewicht und erreichten nach 1 Stunde für TNF- $\alpha$ den maximalen Wert. Die maximale IL-1 Konzentration im Serum wurde erst nach 2-3 Stunden erreicht. Webel et al. (1997) berichtet von einer maximalen Serumkonzentration von TNF- nach 2 Stunden bei einer LPS-Dosis von 0.5-5 $\mu \mathrm{g} / \mathrm{kg}$ Körpergewicht. Die im Versuch an C. jacchus verwendete LPS-Dosis wurde ebenso wie die Versuchsdauer von 3 Stunden aufgrund von Literaturdaten ausgewählt. Die Dosis ist zudem für jede Spezies unterschiedlich. So reagiert das Immunsystem von Papio-Affen auf die LPS-Stimulierung gleich dem des Menschen, aber die Dosierung zur Auslösung dieser Reaktion ist sehr unterschiedlich. Beim Menschen liegt die Dosis im Bereich von ng/kg Körpergewicht, beim Papio ursinus im Bereich von $\mu \mathrm{g} / \mathrm{kg}$ Körpergewicht (Redl et al. 1998). Zudem berichten Hinze-Selch und Mitarbeiter (1997) in einer Monozyten-Zellkultur von einer 100 fach geringeren IL-1 $\beta$ Konzentration in der Squirrl-Affen-Kultur im Vergleich zur humanen Kultur. Die verwendete Dosis in dem Versuch an C. jacchus erwies sich als ausreichend, um eine meßbare Immunreaktion auszulösen. Eine Aussage, ob die maximalen Konzentrationen im Serum erreicht wurden, kann nicht vorgenommen werden, da nur eine Probe genommen wurde.

Die Stimulierung der Zellen mit LPS erfolgt über ein sogenanntes Lipopolysaccharid bindendes Protein (LBP). Espinola. (2002) wies dieses Protein bis zu 100 fach erhöht, nach einer Stimulierung, im Menschen und Kaninchen nach. Dieses Protein bindet LPS und agiert als LPS-LBP-Komplex. Es bindet mit CD14 auf der Zelloberfläche von Monozyten und Makrophagen. Über eine Signalkaskade wird die Freisetzung und Produktion der Cytokine bewirkt.

Die Reaktion auf eine LPS-Stimulation äußert sich nicht nur in der vermehrten Produktion von IL-1 $\beta$ und TNF- $\alpha$. In Versuchen mit peripherer Gabe von LPS erhöhen sich die Niveaus der mRNA von IL-1 $\beta$ und TNF- $\alpha$ in den verschiedenen Hirnregionen (Breder et al. 1993, Wong et al., 1993). Periphere Cytokine beeinflussen so den Hypothalamus. Sie modulieren einerseits über die HPA-Achse die Freisetzung von Corticotropin-releasing Hormone (CRH) und von Adrenocorticotropins (ACTH). CRH stimuliert wiederum die Freisetzung von ACTH. Das in der Hypophyse gebildete ACTH wiederum beeinflußt die Nebenniere Glucocorticoide freizusetzen, die ihrerseits auf einen hemmenden Einfluß die pro-inflammatorischen Cytokine ausüben (Dunn 1992, Straub et al. 1998). Zudem erhöhen diese Cytokine das Prolaktinniveau und modulieren ebenfalls Reproduktionshormone. Darauf soll in den folgenden Punkten näher eingegangen werden. 


\subsubsection{Das Streßhormon Cortisol}

Eins der wichtigsten Glucocorticoide ist das Cortisol. Es ist maßgeblich an der Regulierung von Streß beteiligt und wird daher auch als Streßhormon bezeichnet.

Erwartungsgemäß führte die LPS-Behandlung $\mathrm{zu}$ einer signifikant erhöhten Cortisolkonzentration in der LPS-Gruppe im Vergleich zur Kontrollgruppe. Schon Anfang 1960 wurde nach der Gabe von LPS im Zusammenhang mit Fieber bei Hunden eine Erhöhung des Cortisolspiegels beschrieben Es gibt diverse Studien u.a. an Schweinen (Klin et al. 1997), Kühen (Werling et al.1996), Nagern (Fong et al. 1989) und Hühnern (Klasing et al. 1987), die ebenfalls von einen Anstieg von Cortisol nach LPS-Behandlung als Reaktion auf diese künstliche Stressung berichten. Vedder et al. (1999) wiesen an einer Studie mit Menschen eine LPS-Dosisabhängigkeit der Erhöhung der Cortisolkonzentration nach.

Die Erhöhung des Cortisolspiegels im Serum von C. jacchus kann verschiedene Ursachen haben. Ein Ursprung liegt in der IL-1 $\beta$ Sekretion der Makrophagen. DeRijk et al. (1991, 1997) wiesen an Mäusen bei einer Neutralisierung der Makrophagen einige Tage vor der Injektion mit LPS keinen Anstieg des Glucocorticoidspiegels nach. das von den Makrophagen produzieren IL-1 $\beta$ gelangt über die Blutbahn in die Nebennierenrinde und bewirkt dort die Freisetzung von z.B. Corticosteron in der Ratte (Song \& Leonhard 1995).

Neben der lokalen Auswirkung von IL-1 $\beta$ in der Nebenniere besteht eine Wirkung von IL-1 $\beta$ indirekt über den Vagusnerv auf das Gehirn. Bluthe et al. (1996) zeigten, daß eine Teilsektion des Vagusnerves (SDVX) in Ratten das Krankheitsbild nach Endotoxingabe reduziert. In weiterführenden Versuchen an Ratten wurde von Kapcala et al. (1996) eine Stimulation der ACTH- und Corticosterone-Sekretion durch IL-1 $\beta$ Gabe bei SDVX-behandelten Ratten beeinflußt. Dennoch ist der Stellenwert des Einflusses der afferenten Fasern des Vagusnerves auf diese Vorgänge umstritten (Schwarts \& Ray 1997).

Das in Makrophagen gebildete IL-1 $\beta$ gelangt aber nicht nur in die Nebennieren und beeinflußt die Cortisolproduktion direkt, sondern auch ins Gehirn und stimuliert dort die Freisetzung des Corticotropin-Realising-Hormon $(\mathrm{CRH})$, welches die Freisetzung von ACTH induziert.

Neben IL-1 $\beta$ sind auch die Cytokine TNF- $\alpha$ und IL-6 an der Stimulation von CRHSekretion im Hypothalamus beteiligt (Spinedi et al. 1992). Bei Studien an Ratten 
stellten Besedovsky et al. (1992) fest, daß die Gabe der Cytokine IL-1 $\beta$, TNF- $\alpha$ und IL6 die ACTH- und damit auch die Glucocorticoidkonzentration unterschiedlich stark beeinflussen. IL-1 $\beta$ scheint dabei das größte Potential zu besitzen (Reyes \& Coe 1998). Aber auch dem Cortisol selbst kommt eine tragende Rolle zu. Als einer der wenigen Stoffe ist Cortisol in der Lage die Blut-Hirn-Schranke $\mathrm{zu}$ überwinden und ein „feedback“-Signal auszulösen. So kann Cortisol dort die eigene Sekretion beeinflussen und die Immunantwort modulieren (Spangelo \& Gorospe 1995).

Die eigentliche Wirkung des Cortisols ist jedoch eine Hemmung der inflammatorischen Cytokine. Das Zusammenspiel von Cytokinen und Cortisol stellt ein wichtiges System dar, um eine Überproduktion und Überreaktion des Immunsystems zu verhindern.

\subsubsection{Das Streßhormon Prolaktin}

Neben dem Cortisol wird auch das Hormon Prolaktin als ein wichtiger Indikator für Streß angesehen und ebenfalls zu den Streßhormonen gezählt.

Streß verursacht sehr empfindliche Änderungen in der Prolaktinsekretion. Schon ein fünf Sekunden andauerndes Handling von Laborratten kann zu einer Erhöhung der Prolaktinkonzentration im Plasma der Tiere führten (Seggie \& Brown 1975). Dies könnte die recht hohen Werte der Kontrollgruppe erklären. Die Tiere befanden sich schon durch die Versuchsbedingungen (Handling, Spritzen u.ä.) in einem Streßzustand. Die Auswertung des Prolaktin-Assays zeigte eine signifikant höhere Konzentration von Prolaktin im Serum der LPS-behandelten Gruppe im Vergleich zur Kontrollgruppe. Da es sich bei diesem Hormone um ein sogenanntes akutes Streßhormone handelt, war dies zu erwarten. Auch Ramachandra et al. (1993) untersuchte an Mäusen den Einfluß von LPS auf die Prolaktinsekretion. Erhöhte Prolaktinwerte zeigen sich auch im Zusammenhang mit vielen Erkrankungen, wie z.B. rheumatischer Arthritis (Zoli et al. 2002).

Neben des seit langem bekannten stimulierenden Einflußes von IL-1 $\beta$ auf die Hypophyse bezüglich der Prolaktinfreisetzung scheint die Produktion durch Makrophagen eher gering zu sein, wie Nagy \& Berczi (1991) beobachteten. Eine Hypophysektomie bei Ratten wies eine nur minimale Prolaktinkonzentration im Serum nach und Ließ eine tragende Rolle der Hypophyse in der Produktion des Prolakins 
vermuten. Das in Makrophagen gebildete IL-1 $\beta$ gelangt in das Gehirn und stimuliert dort die Hypophyse und so die Prolaktinfreisetzung (Xiao et al. 2003).

Der Einfluß des Cytokins TNF- $\alpha$ auf die Prolaktinsekretion wird aufgrund verschiedener Ergebnisse von Zellkulturversuchen kontrovers diskutiert. Walton \& Cronin (1990) berichten von einer Hemmung der Prolaktinsekretion, Masumoto \& Kasahara (1991) beschreiben eine Freisetzung von Prolaktin aus den Hypophysen Zellkulturen.

Die Hypophse ist, wie es scheint, nicht der einzige Ort im ZNS an dem PRL synthetisiert wird. Ein sog. prolactin-like protein (PLP), das immunreaktive und bioaktive Eigenschaften aufweist, konnte im Kleinhirn, Thalamus, Hippocampus, Nucleus caudatus und Cortex des Rattengehirns nachgewiesen werden. Die exakte Funktion des neuronalen Prolaktin bleibt weiterhin unklar. Das Vorhandensein von Bindungsstellen im Gehirn spricht zusammen mit dem stimulierenden Effekt auf neuronales Gewebe zur Freisetzung von Neuropeptiden für eine Rolle als Neuromodulator (Weigent et al., 1996).

Im Hinblick auf immunologische Prozesse kommt Prolaktin eine wichtige Rolle zu. Prolaktin kann über spezifische Rezeptoren auf Lymphozyten einwirken und die Prolieferation der T-Lymphozyten verstärken. Zudem kann Prolaktin auch die Produktion inflammatorischen Cytokins IL-2 verstärken. Bernton et al. (1991) zeigten an Mäusen, eine Abschwächung der Lymphozytenproliferation aufgrund von Glucocorticoiden konnte über die Gabe von Prolaktin neutralisiert werden. Prolaktin agiert gegenläufig zum Cortisol und wirkt als Antagonist auf eine glucocorticoidinduzierte Immunsupression. Dadurch wird eine Überreaktion bei der Immunantwort verhindert.

Prolaktin wird heutzutage nicht mehr nur in seiner Rolle als endokrines Hormon, sondern auch in der eines Cytokins diskutiert, das über spezielle Rezeptoren, die von den Immunzellen exprimiert werden, seine Wirkung entfalten kann.

\subsubsection{Das Hormon Testosteron}

Neben einer Beeinflussung von den Streßhormonen Cortisol und Prolaktin ist aus klinischen Untersuchungen über Streßauswirkungen an Menschen bekannt, daß Streß zu vorübergehender Unfruchtbarkeit führen kann. Reaktionen des Immunsystems auf 
Entzündungen, Infektionen oder Autoimmunerkrankungen können die Steroidgenese und Spermatogenese bei Männern hemmen (Cutolo et al. 1988, Buch \& Havlovec 1991).

In den Ergebnissen der Untersuchungen der Testosteronspiegel zeigte sich dies in einer niedrigeren Konzentration der LPS-behandelten Gruppe wieder. O’Bryan et al. (2000) und Gow et al. (2001) berichten in ähnlichen Versuchen an Ratten von einer Reduzierung der Testosteronkonzentration im Serum nach Gabe von LPS, ebenso wie zuvor Bosmann et al. (1996) in einem Versuch an Mäusen.

Sharma und Mitarbeiter (1996 \& 1998) berichten nach Versuchen an Spraque-Dawley Ratten von einem niedrigeren Testosteronspiegel im Serum. In diesem Versuch wurde die unspezifische Sepsis nicht durch eine LPS-Behandlung hervorgerufen, sondern es wurden „cecal slurry“ (homogenisierter Blinddarm) injiziert. Die Verringerung des Testosteronspiegels ist also nicht an eine reine Behandlung mit LPS gekoppelt.

Es gibt verschiedene Ursachen für die beobachtete Auswirkung von LPS auf den Testosteronspiegel im Serum von C. jacchus.

Es ist hinlänglich bekannt, daß LPS Monozyten und Makrophagen deren inflammatorische Funktionen aktivieren(Wallgren et al. 1993, Refojo et al. 1998, O'Bryan et al. 2000). Lymphozyten und Makrophagen exprimieren Cytokine, wie IL$1 \beta$ und TNF- $\alpha$, die über die Blutbahn in die Testis gelangen. Auch die in der Testis angesiedelten Makrophagen, Leydig-Zellen und Sertoil-Zellen sind in der Lage IL-1 $\beta$ und TNF- $\alpha$ zu produzieren (Okuda et al. 1995). IL-1 $\beta$ und TNF- $\alpha$ üben in der Testis einen hemmenden Einfluß auf die Funktion der Leydig-Zellen aus (Harrington et al. 1990).

Wie bereits mehrfach erläutert induziert LPS nicht nur die in der Peripherie produzierten Cytokine IL- $1 \beta$ und TNF- $\alpha$, sondern auch deren Produktion im Gehirn. Dort hemmen sie die Freisetzung von GnRH aus dem Hypothalamus und dadurch auch die LH Sekretion und die Bildung von Testosteron in der Testis, wie Rivest \& Rivier (1995) berichten. Es besteht also ein enger Zusammenhang zwischen einer niedrigen Testosteronkonzentration und einem ebenfalls niedrigeren LH-Wert im Serum.

Das zur Verminderung des Testosterongehalts im Serum von C. jacchus ein Zusammenspiel einer sinkenden LH-Konzentration und der lokalen Hemmung der Leydig-Zellen stattfand, erscheint wahrscheinlich, kann aber aufgrund der Tatsache, daß kein LH-Assay durchgeführt wurde, nicht bestätigt werden. 


\subsection{Das IL-1 System}

In zahlreichen Studien erwiesen sich nicht-humane Primaten als gute Tiermodell, um Streß oder Infektionskrankheiten wie, z.B. Malaria, Tuberkulose und Hepatitis zu untersuchen. Ein gutes Tiermodel ermöglicht einen Vergleich verschiedenster pathologischer und physiologischer Prozesse in Tier und Mensch vorzunehmen. Daher ist es das Bestreben vieler Arbeitsgruppen die Moleküle des Immunsystems der nichthumanen Primaten näher zu charakterisieren. Neben den Auswirkungen der LPSInjektion auf die wichtigsten Cytokine und Streßhormone im Serum von C. jacchus wurden in dieser Arbeit erstmals eine Möglichkeit zur Identifizierung (partielle Sequenzen) der einzelnen IL-1-Systemkomponenten im Gehirn von C. jacchus entwickelt, um so mögliche Veränderungen auf histologischer Ebene darzustellen zu können.

\subsubsection{Die Sequenzen des IL-1 Systems}

Um ein geeignetes Tiermodel $\mathrm{zu}$ finden, ist es wichtig auf eine größstmögliche Übereinstimmung der immunologischen Prozesse auf molekularer Ebene zwischen Mensch und Tier zu achten (Paul \& Seder 1994, Hall \& Rao 1992). Neben einem Vergleich der Wirkung bestimmter Stoffe in Mensch und Tier, wie z.B. den Cytokinen, ist eine weitere Möglichkeit die Sequenzen der Cytokine auf Nukleotid- oder Aminosäuren-Niveau miteinander zu vergleichen. So kann eine Aussage über die Sensitivität beim Nachweis dieser Stoffe getroffen werden. Um auch geringste Mengen überhaupt nachweisen zu können (basale Cytokinniveaus) war es notwendig ein sehr sensibles Detektionsystem zu entwickten.

Ein Vergleich der in dieser Arbeit klonierten und sequenzierten partiellen CytokinNukleotid-Sequenzen von $C$. jacchus mit den Humansequenzen aus der PubMed Datenbank wies eine Übereinstimmung von über $92.4 \%$ bzw. $92.6 \%$ Agonist IL-1 $\beta$ und den Antagonist IL-1ra auf. Die beiden Rezeptoren zeigen mit $94.3 \%$ für IL-1RI und mit 94.0 \% für IL-1RII ebenfalls eine fast gleiche Homologie auf. In einer Arbeit von Villinger et al. (1995) über die vergleichende Sequenzanalyse von einzelnen Cytokingenen von Menschen und nicht-humanen Primaten (M. mulatta, M. nemestina und $C$. atys) zeigten sich ähnlich hohe Übereinstimmungen. Während die Homologien 
zwischen den einzelnen Primatenarten im Schnitt 96-100 \% betrug, wiesen die Vergleiche von Human- mit Primatensequenzen eine Homologie von 91-97 \% auf. Die Sequenzhomologien zwischen den Primatencytokinen war somit größer als zwischen Primaten und Menschen. Die im Vergleich zum Menschen berechneten Homologien für C. jacchus weisen mit $92 \%$ eine ähnlich starke Homologie auf, wie die oben angeführten Vergleiche.

Die Unterschiede in den Aminosäuresequenzen und den Nucleotidsequenzen zwischen den einzelnen Primatenarten und dem Menschen könnte auf eine modifizierte Bioaktivität innerhalb der Spezies zurückgehen. Diese Modifizierungen zeigen sich z.B. in den verschiedenen relevanten Epitope von monoklonalen Antikörper und ihren spezifischen Bindungregionen, die für die Bindung an ihre Rezeptoren wichtig sind. Dafür spricht auch ein Versuch von Smith et al. (2002) zum Bindungsverhalten von humanen IL-1 $\beta$ und Cynomolgus (Javaneraffen)-IL-1 $\beta$ an den IL-1RII. Während humanes IL-1 $\beta$ mit einer hohen Affinität an den IL-1RII gebunden hat, zeigte sich beim M. fascicularis IL-1 $\beta$ eine nur geringe Bindungsaffinität. Smith et al. führen dies auf den Unterschied von einer einzigen Aminosäure in der zur Bindung wichtigen Proteinregion zurück. Dennoch ist die hohe Bindungskapazität anscheinend nicht notwendigerweise auf die humane Spezies beschränkt, da in einem weiteren Versuch von Smith et al. (2002) nachgewiesen werden konnte, daß sich die für die Bindung wichtigen Sequenzregionen von Menschen und Schimpansen nicht unterscheiden. Diese Unterschiede können bei der Entwicklung eines Tiermodells von großer Relevanz sein und müssen berücksichtigt werden. Über vielleicht diesbezüglich vorhandene Unterschiede zwischen C. jacchus und dem Menschen können keine Aussagen aufgrund von fehlenden Daten gemacht werden.

Bezüglich der Eignung der in dieser Arbeit klonierten Sequenzen des IL-1 Systems von C. jacchus und den verwendeten Antikörpern läßt sich folgendes sagen: Alle verwendeten monoklonalen humanen Antikörper der Firma R\&D Systems gegen IL-1 $\beta$, IL-ra, IL-RI und IL-1RII wiesen Kreuzreaktionen mit $C$. jacchus auf und eigneten sich zur Detektion der IL-1-Systemkomponenten im Gehirn von C. jacchus. Lediglich mit dem monoklonalen humanen Antikörper gegen IL-1 $\beta$ der Firma Santa Cruz konnte kein Signal erzielt werden. Dies könnte auf einen Unterschied in der Bindungsdomäne dieses Antikörpers zurückgehen und seine Ursache in einem Sequenzunterschied haben. Bei den Bestimmungen der Cytokine im Serum wurden ein humaner Assay für IL- $\beta$ und ein 
Rhesusaffen-Assay für TNF- $\alpha$ verwendet. Auch die dort verwendeten Antikörper zeigten ebenfalls Kreuzreaktionen mit C. jacchus.

\subsubsection{Histologische Verteilung und Bedeutung der einzelnen IL-1 Systemkomponenten}

Neben der Entwicklung einer Möglichkeit zur Charakterisierung des IL-1-System im Krallenaffen $C$. jacchus wurde erstmals auch ein Nachweis der einzelnen IL-1 Systemkomponenten im Gehirn von $C$. jacchus vorgenommen und deren Verteilungsmuster untersucht. Mit Hilfe der Technik der in-situ Hybridisierung und der Immunhistochemie wurde das Verteilungsmuster im Gehirn untersucht.

Eine Identifizierung der Zelltypen, welche die einzelnen Komponenten exprimieren wurde mittels immunhistologischen Antikörpernachweisen angestrebt.

\subsubsection{Der Agonist Interleukin-1 beta}

Es wurde ein Nachweis von IL-1 $\beta$ in LPS-stimulierten (Streß) und zur Kontrolle mit NaCl-behandelten Tieren durchgeführt und deren Verteilungsmuster untersucht. In den vorgenommenen Untersuchungen mittels IHC und ISH konnte auch ein Nachweis von IL-1 $\beta$ in den Kontrolltieren erbracht werden. Auch Szelenyi (2001) berichtet über eine ständige Expression von Cytokinen im Gehirn von Nagern. Andere Studien berichten, daß eine Detektion von IL-1 $\beta$ im Gehirn unter nicht-stimulierten Bedingungen nicht möglich war. Es ist anzunehmen, daß die Kontrolltiere aufgrund der Versuchsbedingungen schon gestreßt z.B. durch das Handling waren. Ratten und Mäuse reagieren in der Regel nicht so empfindlich auf das Einfangen, wie z.B. die Primaten, da die Nager das tägliche Umsetzen gewöhnt sind. Während Nager im Versuch meist an kleine Käfige gewöhnt sind, löst ein kleiner Käfig und der Verlust des sozialen Kontaktes zu den Familienmitgliedern/Partnern bei den Callithrix Streß aus, der wiederum zu einer Erhöhung des IL-1 $\beta$ Spiegels führen kann. Daher erscheint es wahrscheinlich, daß nicht die tatsächlichen basalen Expressionen beobachtet wurde.

Die Technik der RT-PCR, wie sie z.B. von Yu \& Lau (2000) zum Nachweis von Cytokinen im Gehirn verwendet wurde, ist im allgemeinen sensibler als die Technik der 
IHC und ISH und kann daher auch kleinste Spuren dieser Stoffe nachweisen. Mit der ISH und der IHC ist ein so feiner Nachweis nicht möglich. Die in dieser Arbeit verwendete neue GenPoint Methode der ISH ist auch viel sensibler als die bisher gebräuchlichen Methoden. Dies könnte u.a. auch zum Teil den Nachweis der Cytokine unter nicht-stimulierten Bedingungen erklären.

Bei C. jacchus gelang ein positiver Nachweis von IL-1ßmRNA in der Mikroglia im Cortex, Striatum, Claustrum, Hypothalamus und Hippocampus, sowie ein positiver Proteinnachweis auf den Neuronen des Cortex, Striatums und den Pyramidenzellen des Hippocampus (Area CA1-CA4 hippocampi). Da bisher keine Daten für C. jacchus vorlagen, wurde ein Vergleich zu ähnlichen Untersuchungen, vornehmlich an Ratten, vorgenommen. In Studien von Minami et al. $(1990,1991)$ und einer späteren Arbeit derselben Gruppe (Yabuuchi et al. 1994) wurde mit ISH IL-1 $\beta$ mRNA in verschieden Gehirnregionen von an Ischämie leidenden Ratten mittels ISH nachgewiesen, wie im cerebralen Cortex, in der polymorphen Schicht des Hippocampus, im Striatum (Nukleus caudatus \& Putamen) und im Thalamus. Nach Yabuuchi und Mitarbeitern (1994) scheint der Ursprung der positiven ISH Signale die Mikroglia zu sein. Als Nachweis für diese Zuordnung dient eine Untersuchung, in der IL-1 $\beta$ mRNA positive Gliazellen identifiziert werden konnten, die nicht GFAP (spezifisch für Astroglia) positiv waren (Yabuuchi et al. 1993). Ähnliche Beobachtungen konnten auch in der vorliegenden Untersuchung im Gehirn von C. jacchus gemacht werden und daher wurden die positiven IL-1 $\beta$ mRNA-Signale im Hippocampus der Mikroglia zugeordnet. In Zellkulturexperimenten wurde zudem eine IL-1 $\beta$ mRNA Expression auch in mit LPSstimulierten Astroglia-(Lieberman et al. 1990) und Mikrogliazellkulturen (Guilian et al. 1986) nachgewiesen.

IL-1 $\beta$ wurde im Hinblick auf die Wirkung bei neurodegenerativen Erkrankungen, Infektionen und Trauma in den letzten Jahren häufig untersucht, wie z.B. von Breder et al. (1988). Makrophagen des Gehirns und Mikrogliazellen sind bekannte Produzenten von IL-1 $\beta$ unter pathologischen Veränderungen. Die Erkrankung an Multipler Sklerose und Alzheimer (Merrill 1992) ist eng mit der Aktivierung der IL-1 $\beta$ Produktion in der Mikroglia verbunden (Merrill et al. 1991). Die IL-1 $\beta$ sensitiven neuronalen Zellen vom frontoparietalen Cortex und Hippocampus sind anscheinend für einen Neuronenverlust z.B. im Cortex von an ADIS erkrankten Patienten verantwortlich (Wiley et al. 1988). In Gliazellen produziertes IL-1 $\beta$ steht also in einem engen Zusammenhang mit Neuronen. 
Im Gehirn von nicht LPS-stimulierten $C$. jacchus ließen sich auch IL-1 $\beta$ mRNA positive Neurone nachweisen (siehe 3.2.6). Neben den Gliazellen sind anscheinend auch Neurone auch unter nicht-stimulierten Bedingungen in der Lage IL-1 $\beta$ zu exprimieren (bei Ratten: Lynch 2002 und Minami et al. 1991). Diese Aussage wird in der Literatur kontrovers diskutiert, da verschiedenste Gruppen trotz ähnlicher Methoden zu unterschiedlichen Ergebnissen gelangen. Es gibt sowohl Berichte, die für eine IL-1 $\beta$ Expression im normalen ZNS sprechen, als auch Ergebnisse, die von einer fehlenden Expression berichten. Ein Grund für die Schwierigkeiten des Nachweis könnte darin liegen, daß die Signalwirkung von IL-1 $\beta$ im Gehirn viel stärker ist, als in der Peripherie. Dies zeigt sich in einem Vergleich von Stimulierungsversuchen mit Injektion von IL-1 $\beta$ in die Peripherie und das Gehirn. Um dieselbe Änderung zu erzielen ist in der Peripherie eine bis zu 100 fach höhere Dosierung nötig. Dies verdeutlicht, warum die Konzentrationen dieser Stoffe im „Normalzustand“ im Gehirn mehr als nur gering sind. Vitkovic et al. (2000) sprechen in diesem Zusammenhang von einer geringen Expression von Cytokinengenen und deren Rezeptoren in Neuronen im Gehirn während des „Normalzustandes“ (basales Niveau). Hinter der Lokalisation in Neuronen wird eine Regulierung von neuronal gesteuerten Funktionen vermutet. Wird im gesunden Tier z.B. IL-1 $\beta$ blockiert, so kann es u.a. zu einer Veränderung im Schlafverhalten, einem neuronal gesteuerten Vorgang, kommen. In diesem Fall könnten diese speziellen Cytokine auch als Neuromodulatoren bezeichnet werden. Die Expression in der Mikroglia wird dagegen der Immunantwort zugeschrieben, die schnell auf Veränderungen reagieren muß.

\subsubsection{Der Interleukin-1 Rezeptor Antagonist}

In der vorliegenden Arbeit konnte neben dem Liganden IL-1 $\beta$ auch sein Antagonist, der natürlich auftretende IL-1ra in denselben Hirnarealen von C. jacchus nachgewiesen werden. Es konnten positive IL-1ra mRNA-Signale, sowohl in der Mikroglia als auch in den großen Pyramidenzellen des Hippocampus (Area CA1-CA4 hippocampi) nachgewiesen werden. Proteinsignale zeigten sich vorwiegend beim LPS-behandelten Tier im Cortex und Hippocampus. Dies entspricht einem immunhistochemischen Nachweis von IL-1ra in Neuronen des humanen Cortex und Hippocampus von Yasuhara et al. (1997). Eriksson et al. (1998) identifiziert in der Ratte mittels ISH nach 
peripherer Stimulierung IL-1ra Expressionen in der Mikroglia des Hippocampus, Thalamus, Cortex und Teilen des Hypothalamus.

Neben der Mikroglia sind auch Astrogliazellen in der Lage IL-1ra zu exprimieren, wie Mikroglia- (Giulian et al. 1986) und Astroglia- (Lieberman et al. 1989) Zellkulturstudien an Ratten belegten. Auch menschliche Mikrogliazellen können IL-1ra produzieren (Tada et al. 1994).

Die Verteilung von IL-1ra mRNA parallel zu der von IL-1 $\beta$ macht im Hinblick auf die funktionellen Zusammenhänge einen Sinn. IL-1 ra wird durch die Expression von IL-1 $\beta$ stimuliert, dient aber hauptsächlich dazu IL-1 $\beta$ indirekt $\mathrm{zu}$ hemmen. Aus diversen Versuchen ist bekannt, daß die Gabe von IL-1ra z.B. bei einer Sepsis den Schock und die Krankheitssymptome mindern kann, sowohl bei Menschen (Ohlsson et al. 1990), als auch bei Tieren, wie z.B. Kaninchen (Wakabayashi et al. 1991).

Untersuchungen der letzten Jahre zeigen eine IL-1ra Expression in Neuronen von an Alzheimer und der Pick-Krankheit erkrankten Menschen (Yasuhara et al. 1997). Yasuhara et al. (1997) spricht in diesem Zusammenhang von IL-1ra produziert in normalen Neuronen, die aufgrund einer pathologischen Ursache stimuliert wurden. Die in dieser Arbeit vorgenommenen ISH mit antisense IL-1ra Sonden zeigten deutlich positive Pyramidenzellen der Regionen CA1-CA4 des Hippocampus. Ähnliche Befunde weist auch Yasuhara et al. nach. Eine Hauptfunktion von IL-1ra ist es Zellen vor einer Überstimmulation mit IL-1 $\beta$ zu schützen. In diesem Fall kommt den Neuronen eine große Bedeutung zu. Bei Stimulation, Streß oder Krankheiten kommt es, wie schon erläutert, zu einer vermehrten Expression von IL-1 $\beta$ durch die Mikroglia. Die Rezeptoren für IL-1 $\beta$, die im Anschluß an diesen Punkt näher erläutert werden, sind ebenfalls auf Neuronen lokalisiert. Die Kolokalisation von IL-1ra mit den Rezeptoren von IL-1 $\beta$ auf denselben Neuronen erscheint sinnvoll. Die Hypothese, daß die Stimulation der IL-1ra Produktion durch Neurone einen positiven therapeutischen Effekt bei Krankheiten, wie Alzheimer und Multipler Sklerose haben könnte, bedarf weiterer Forschung.

\subsubsection{Die beiden Interleukin-1 Rezeptoren Typ I und Typ II}

Neben dem Agonisten IL-1 $\beta$ und dem Antagonisten IL-1ra gehören noch zwei Rezeptoren zu dem IL-1 $\beta$ System. Beide Rezeptortypen wiesen eine annähernd gleiche 
Verteilung im Gehirn auf und waren in den selben Hirnregionen wie IL-1 $\beta$ und IL-1ra zu finden. Die Signale des IL-1RI waren nicht ganz so stark, wie die vom IL-1RII.

Der ISH zeigte für den Rezeptor Typ II eine schwache gliale Lokalisation an. Die Signale der IL-1RI waren zu schwach, um eine solche Zuordnung vornehmen zu können. Das kann einerseits an dem Signal selber gelegen haben, oder an der Färbung, wobei letzteres unwahrscheinlich erscheint, da die Färbungen für den IL-1RI gleichmäßig schwach waren. Vielmehr läßt sich eine geringere Expression von IL-1RI vermuten. Parallel $\mathrm{zu}$ den eigenen Befunden im Gehirn von C. jacchus wiesen verschiedene ISH Studien zunächst den IL-1RI in nicht-neuronalen Zellen (Mikroglia, Astroglia) nach, die als Barriere zwischen der Peripherie und dem ZNS fungieren. Aus Studien in vivo und in vitro ist bekannt, daß auch Gliazellen IL-1 $\beta$ binden können (Ban et al. 1993a,b). Mit radioaktiv markierten IL-1 $\beta$ wurde die Bindung an die Rezeptoren an Gliazellen in einem Mäusegehirn untersucht. Nach Friedman (2001) zeigen IL-1R Expressionen in Gliazellen sich erst nach z.B. Läsionen deutlich. Ein Nachweis ohne vorherige Stimulierung war nicht möglich. Dies spricht für einen engen Zusammenhang zwischen IL-1 $\beta$ und den IL-1R bei der Immunantwort.

Neben der schwachen glialen Expression wies die ISH, im Gegensatz zu IL-1 $\beta$ oder IL1ra, den Rezeptor Typ I und Typ II hauptsächlich stark in neuronale Zellen nach. neben positiven Zellen im Cortex und wurden auch im Hippocampus positive Zellen gefunden und dort vorwiegend in der Zellen der Fascia dentata und der großen Pyramidenzellen der Regionen CA1-CA4, nach. Einen ähnlichen Befund machte Friedman (2001) im Hippocampus von Ratten. In weiterführenden Untersuchungen gelang es Friedman (2001) in einer Zellkultur mit Embryo-Hippocampus-Neuronzellen durch Stimulierung mit IL-1 $\beta$ eine erhöhte Expression von IL-1RI nachzuweisen. Auch Takao et al (1992) wiesen eine neuronale Lokalisation von IL-1RI im Hippocampus nach. Yabuccchi et al. (1994) wies die IL-1RI mRNA speziell in den Pyramidezellen des Hippocampus der Ratten nach. Da die Expression von IL-1RI und IL-1RII auch unter basalen Bedingungen in den Neuronen des Hippocampus nachzuweisen war, scheint auch IL-1 $\beta$ eine Rolle in der „,normalen Funktion“ dieser Neurone zu spielen (Punkt 4.2.2.1). Breder et al. zeigten 1998 in einer immunhistologischen Studie, daß im menschlichen Gehirn im Hypothalamus IL-1 $\beta$ immunoreaktive Fasern gibt. Ähnliche Fasern wurden in Versuchen an Ratten im Hypothalamus und Hippocampus gefunden (Lechan 1990). Es scheint auch im Gehirn von C. jacchus diese neuronalen Fasern zu geben. Bei der immunhistologischen Detektion von IL-1 $\beta$ im Gehirn von C. jacchus waren die 
Pyramidenzellen der Regionen CA1-CA4 deutlich positiv. Unter Berücksichtigung der Lokalisation der beiden Rezeptoren mittels ISH, liegt eine Wirkung von IL-1 $\beta$ auf neuronalen Fasern nahe.

\subsection{Der quantitative Nachweis des Agonisten IL-1 $\beta$ und des Antagonisten IL-1ra}

Zusätzlich zum Nachweis und zur Verteilung der einzelnen IL-1 Systemkomponenten wurde erstmals für C. jacchus ein System zur Quantifizierung und zum Nachweis der Expression der IL-1 Systemkomponenten mittels RT-PCR (TaqMan) in ausgesuchten irnarealen entwickelt. Die Sensitivität der RT-PCR Technik ermöglichte es sehr niedrige Cytokinniveaus in verschiedenen Hirnstrukturen unter basalen oder stimulierten Bedingungen zu bestimmen.

Es gelang die basalen Expressionsniveaus zu messen. Es zeigten sich unterschiedliche hohe Expressionen von IL-1 $\beta$ und IL-1ra in den verschiedenen Hirnarealen. IL-1 $\beta$ wies im Vergleich zum Hippocampus im Claustrum eine höhere Expression und im Cortex eine geringere Expression auf. Beim IL-1ra waren die Unterschiede größer und im Vergleich zur Expression im Hippocampus war die Expression im Cortex höher und im Claustrum noch stärker. Diese Expressionen in Gehirnen der Kontrollgruppe können verschiedene Ursachen haben. $\mathrm{Zu}$ einen können die Expressionen auf die ständige Expression dieser Cytokine im Gehirn von C. jacchus zurückgeführt werden, was dem eigentlichen Basalniveau entsprechen würde. Zum anderen ist zu vermuten, daß auch die Kontrolltiere aufgrund der Versuchsbedingungen gestreßt waren und deswegen höhere Niveau der Cytokine aufwiesen. Für einen Vergleich zwischen stimulierten und nicht-stimulierten Tieren ist dies jedoch nicht maßgeblich, da alle Versuchstiere gleich behandelt wurden.

Im Gehirn werden die Cytokine auf verschiedene Weise exprimiert, was auf die unterschiedlichen Wirkungsweisen zurückzuführen sind. Zum einen werden Cytokine ständig auf einem niedrigen Niveau in Neuronen exprimiert und sind an der neuronale Verschaltung beteiligt. Zum anderen werden die Cytokine für die schnelle Reaktion des Systems auf Stimulierung über die Mikroglia ausgeschüttet.

Beim Vergleich der stimulierten relativen mRNA Expressionen in den einzelnen Hirnarealen zeigte sich ein Unterschied der beiden untersuchten Cytokine. Für IL-1 $\beta$ 
war die Erhöhung der IL-1 $\beta$ mRNA Niveaus der stimulierten Tiere signifikant erhöht im Vergleich zur Kontrolle. Bei dem IL-1ra waren sie nicht signifikant erhöht.

Ein Anstieg der IL-1 $\beta$ Expression war zu erwarten, da es sich um das wichtigste Cytokin handelt und es seinen Ursprung in einer erhöhten Produktion der Mikroglia hat. Die Auswirkungen von IL-1 $\beta$ wurden bereits unter Punkt 4.2.2.1 beschrieben. Die Expression von IL-1 ra startet zeitlich versetzt zu der von IL-1 $\beta$. Dies zeigte Eriksson et al. (1998) an Ratten. Nach einer peripheren Stimulierung kam es zuerst zu einer vermehrten IL-1 $\beta$ Expression. Die Expression von IL-1ra stieg erst 5 Stunden nach Stimulierung an, ungefähr zu der Zeit, wo erste degenerierende Neurone auftauchten. Studien, die sich mit Ischämie beschäftigen berichten von ähnlichen zeitlich versetzten Expressionen von IL-1 $\beta$ und IL-1ra (Buttini et al. 1994, Liu et al. 1993, Loddick et al. 1997, Minami et al. 1992 Ericksson et al. 1999). lokalisierten die Proteine von IL-1 $\beta$ und IL-1ra zu verschiedenen Zeiten in unterschiedlichen Hirenarealen. 5 Stunden nach Stimulierung waren in der Mikroglia im Hippocampus und im Cortex immunreaktive IL-1 $\beta$ Zellen nachweisbar, aber noch keine IL-1ra Zellen. Diese konnten erst zu einem späteren Zeitpunkt nachgewiesen werden. Die für die hier vorliegende Arbeit gewonnenen Proben wurden nach 3 Stunden genommen. Daher wäre ein starker Anstieg der IL-1ra mRNA Expression noch nicht $\mathrm{zu}$ beobachten. Die zeitliche Beziehung zwischen der IL-1 $\beta$ Expression und dem IL-1ra läßt eine ähnliche Kopplung von IL-1 $\beta$ und IL-1ra wie bei der peripheren Immunantwort vermuten (Granowitz et al. 1991a,b). Im Hinblick auf den Zweck einer Abwehrreaktion ist diese zeitlich versetzte Expression von IL-1 $\beta$ und IL-1ra durchaus sinnvoll. Die gleichzeitige starke Expression von IL-1ra würde die Wirkung von IL-1 $\beta$ negativ beeinflussen. Die Signalübertragung von IL-1 $\beta$ ist jedoch wichtig, um eine körpereigene Abwehr auszulösen. Eine Blockierung dieser Reaktion ist daher nicht sinnvoll. IL-1ra kommt bei der Regulierung dieser körpereigenen Abwehr eine wichtige Rolle zu. Der IL-1ra soll Zellen vor einer Überstimulation mit IL-1 $\beta$ und damit vor einer Überreaktion schützen.

Bei einem Vergleich der für diese Arbeit gewonnenen Daten bezüglich der einzelnen Hirnareale war die LPS-Stimulierung von IL-1 $\beta$ im Hippocampus ähnlich stark, wie im Cortex. Im Vergleich dazu war die Expression im Claustrum nicht im selben Maß stimuliert. Die Stimulierung verursachte eine leichte Erhöhung der Expression von IL1ra im Cortex wie auch im Hippocampus. Im Claustrum hingegen hatte die Stimulierung auf die IL-1ra Expression fast gar keine Wirkung. Ähnliche Ergebnisse 
finden sich in einer Studie von Gayle et al. (1998). LPS-stimulierte Ratten wiesen eine signifikant höhere IL-1 $\beta$ mRNA Expression im Hippocampus, aber eine nur leicht erhöhte mRNA Expression von IL-1ra in derselben Region im Vergleich zur Kontrolle auf. Ein Grund für das ähnliche Expressionsverhalten von IL-1 $\beta$ und IL-1ra (Cortex $\geq$ Hippocampus > Claustrum) ist, was den Expressionsort angeht auf eine gleiche Lokalisation von IL-1 $\beta$ und IL-1ra zurückzuführen. Was die geringe Expression von IL1ra angeht, so wurde bereits weiter oben die zeitlich versetzte Beziehung von IL-1 $\beta$ und IL-1ra besprochen. Streßauslösende Ereignisse können die Cytokinproduktion in unterschiedlichen Hirnarealen beeinflussen. So berichten Minami und Mitarbeiter (1991) in einer Studie an Ratten, daß eine Imobilisierung der Tiere zu einem Anstieg der IL-1mRNA Expression im Hypothalamus führte, aber in anderen Hirnregionen keine Veränderungen gefunden wurden. Dagegen berichtet Tanebe et al. (2000) von einer durch Kältestreß starken Erhöhung der Expression im Hippocampus und einer weniger stark erhöhten Expression im Cortex. Eine Stimulierung mit LPS führte bei Ratten zu einer verstärkten Expression von IL-1 $\beta$ und IL-1ra in Hypothalamus und Hippocampus (Ilyin et al. 1998). Dies läßt eine unterschiedliche Reaktion der verschiedenen Hirnstrukturen auf die Art der periphere Stimulation vermuten.

Zusammenfassend läßt sich sagen, daß es gelungen ist, ein neues Tiermodell vorzustellen. Nach der Klonierung und Teilsequenzierung der IL-1 $\beta$-Systemkomponenten konnte eine Verteilung mittels zwei Techniken in speziellen Gehirnarealen beschrieben werden. Damit wurde eine Grundlage geschaffen für zukünftige Untersuchungen im Hinblick auf Gehirnareale, die für die spezifische Regulation des IL-1 $\beta$-Systems verantwortlich sind. 


\section{$5 \quad$ Zusammenfassung}

Als neues Tiermodell zur Untersuchung des Interleukin-1 $\beta$-Systems wurde die Gattung der nichtmenschlichen Primaten Callithrix jacchus ausgewählt.

In der vorliegenden Arbeit wurde zunächst erstmals der Einfluß der künstlichen Stressung mittels Lipopolysaccharid (LPS) und deren Auswirkung auf die Cytokine und den Hormonhaushalt in C. jacchus untersucht. Die stimulierende Wirkung der LPSGabe zeigte sich deutlich in den Untersuchungen der Streßhormone und Cytokine. Es konnte eine zuverlässige Methode zur Identifizierung (partiellen Sequenzen) der einzelnen Interleukin-1 (IL-1) Systemkomponenten im Gehirn von C. jacchus entwickelt werden. Damit gelang auch ein Nachweis der IL-1 Systemkomponenten unter basalen Bedingungen. Mit Hilfe der Technik der in-situ-Hybridisierung und der Immunhistochemie konnte erstmals ein Verteilungsmuster der einzelnen IL-1 Systemkomponenten im Gehirn von C. jacchus erstellt werden. Neben Expressionen in Gliazellen konnten auch für IL-1 $\beta$ und IL-1ra Expressionen in Neuronen nachgewiesen werden. Es wurden zudem verschiedene Hirnareale, Cortex, Claustrum und Hippocampus näher betrachtet.

Zum Nachweis, aber auch zur Quantifizierung von IL-1 $\beta$ und IL-1ra wurde ein sensibles RT-PCR System entwickelt. Mit dieser Methode konnte eine signifikante Stimulierung der IL-1 $\beta$ Expression im Cortex, Claustrum und Hippocampus durch periphere Gabe von LPS nachgewiesen werden. Die IL-1ra Expression stieg im Vergleich nicht signifikant.

Aufgrund dieser Ergebnisse konnte ein neues Tiermodell vorgestellt werden. Für zukünftige Untersuchungen im Hinblick auf die Regulation des IL-1 Systems im Gehirn wurden so entscheidene Grundlagen erarbeitet. 


\section{$6 \quad$ Literaturverzeichnis}

AREND W.P. \& MASSONI R.J. (1986) Characteristics of bacterial lipopolysaccharide induction of interleukin 1 synthesis and secretion by human monocytes. Clin.Exp.Immunol. 64, 656-664.

BAN E., MARQUETTE C., SARRIEAU A., FITZPATRICK F., FILLION G., MILON G., ROSTENE W. \& HAOUR F. (1993) Regulation of interleukin-1 receptor expression in mouse brain and pituitary by lipopolysaccharide and glucocorticoids. Neuroendocrinology 58, 581-587.

BAN E.M., SARLIEVE L.L. \& HAOUR F.G. (1993) Interleukin-1 binding sites on astrocytes. Neuroscience 52, 725-733.

BANKS W.A., ORTIZ L., PLOTKIN S.R. \& KASTIN A.J. (1991) Human interleukin (IL) 1 alpha, murine IL-1 alpha and murine IL-1 beta are transported from blood to brain in the mouse by a shared saturable mechanism. J Pharmacol.Exp.Ther. 259, 988-996.

BERNARDINI R., JOHNSON E.O., KAMILARIS T., CHIARENZA A., CANTARELlA G., CALOGERO A.E., LEMPEREUR L., CHROUSOS G.P., GIUFFRIDA R. \& GOLD P.W. (2001) Increased ACTH and cortisol secretion after interleukin-alpha injection in the common marmoset (Callithrix jacchus jacchus). Life Sci. 68, 1657-1665.

BERNTON E., BRYANT H., HOLADAY J. \& DAVE J. (1992) Prolactin and prolactin secretagogues reverse immunosuppression in mice treated with cysteamine, glucocorticoids, or cyclosporin-A. Brain Behav.Immun. 6, 394-408.

BESEDOVSKY H.O. \& DEL REY A. (1992) Immune-neuroendocrine circuits: integrative role of cytokines. Front Neuroendocrinol. 13, 61-94.

BETANCUR C., BORRELL J. \& GUAZA C. (1995) Cytokine regulation of corticosteroid receptors in the rat hippocampus: effects of interleukin-1, interleukin-6, tumor necrosis factor and lipopolysaccharide. Neuroendocrinology 62, 47-54.

BLUTHE R.M., WALTER V., PARNET P., LAYE S., LESTAGE J., VERRIER D., POOLE S., STENNING B.E., KELLEY K.W. \& DANTZER R. (1994) Lipopolysaccharide induces sickness behaviour in rats by a vagal mediated mechanism. C.R.Acad.Sci.III 317, 499-503.

BLUTHE R.M., MICHAUD B., KELLEY K.W. \& DANTZER R. (1996) Vagotomy blocks behavioural effects of interleukin-1 injected via the intraperitoneal route but not via other systemic routes. Neuroreport 7, 2823-2827.

BLUTHE R.M., MICHAUD B., KELLEY K.W. \& DANTZER R. (1996) Vagotomy attenuates behavioural effects of interleukin-1 injected peripherally but not centrally. Neuroreport 7, 1485-1488. 
BOSMANN H.B., HALES K.H., LI X., LIU Z., STOCCO D.M. \& HALES D.B. (1996) Acute in vivo inhibition of testosterone by endotoxin parallels loss of steroidogenic acute regulatory (StAR) protein in Leydig cells. Endocrinology 137, 4522-4525.

BREDER C.D., TSUJIMOTO M., TERANO Y., SCOTT D.W. \& SAPER C.B. (1993) Distribution and characterization of tumor necrosis factor-alpha-like immunoreactivity in the murine central nervous system. J Comp Neurol. 337, 543-567.

BUCH J.P. \& HAVLOVEC S.K. (1991) Variation in sperm penetration assay related to viral illness. Fertil.Steril. 55, 844-846.

BUTTINI M., SAUTER A. \& BODDEKE H.W. (1994) Induction of interleukin-1 beta mRNA after focal cerebral ischaemia in the rat. Brain Res Mol.Brain Res 23, 126-134.

CERRETTI D.P., KOZLOSKY C.J., MOSLEY B., NELSON N., VAN NESS K., GREENSTREET T.A., MARCH C.J., KRONHEIM S.R., DRUCK T., CANNIZZARO L.A. \& . (1992) Molecular cloning of the interleukin-1 beta converting enzyme. Science 256, 97-100.

CHAO C.C., HU S., SHENG W.S. \& PETERSON P.K. (1995) Tumor necrosis factoralpha production by human fetal microglial cells: regulation by other cytokines. Dev.Neurosci. 17, 97-105.

CHIEN A., EDGAR D.B. \& TRELA J.M. (1976) Deoxyribonucleic acid polymerase from the extreme thermophile Thermus aquaticus. J Bacteriol. 127, 1550-1557.

COLOTTA F., RE F., MUZIO M., BERTINI R., POLENTARUTTI N., SIRONI M., GIRI J.G., DOWER S.K., SIMS J.E. \& MANTOVANI A. (1993) Interleukin-1 type II receptor: a decoy target for IL-1 that is regulated by IL-4. Science 261, $472-475$.

COLOTTA F., DOWER S.K., SIMS J.E. \& MANTOVANI A. (1994) The type II 'decoy' receptor: a novel regulatory pathway for interleukin 1. Immunol.Today $15,562-566$.

CUNNINGHAM E.T., Jr., WADA E., CARTER D.B., TRACEY D.E., BATTEY J.F. \& DE SOUZA E.B. (1992) In situ histochemical localization of type I interleukin-1 receptor messenger RNA in the central nervous system, pituitary, and adrenal gland of the mouse. J Neurosci. 12, 1101-1114.

CUNNINGHAM E.T., Jr., WADA E., CARTER D.B., TRACEY D.E., BATTEY J.F. \& DE SOUZA E.B. (1992) Distribution of type I interleukin-1 receptor messenger RNA in testis: an in situ histochemical study in the mouse. Neuroendocrinology 56, 94-99.

CUNNINGHAM E.T., Jr. \& DE SOUZA E.B. (1993) Interleukin 1 receptors in the brain and endocrine tissues. Immunol.Today 14, 171-176.

CUTOLO M., BALLEARI E., GIUSTI M., MONACHESI M. \& ACCARDO S. (1988) Sex hormone status of male patients with rheumatoid arthritis: evidence of low 
serum concentrations of testosterone at baseline and after human chorionic gonadotropin stimulation. Arthritis Rheum. 31, 1314-1317.

DANTZER R. (1993) Psychoneuroendocrinology on the move. Psychoneuroendocrinology 18, 1-2.

DANTZER R. (1994) [Neurotropic effects of cytokines: at the limits of immunology and neurobiology]. Pathol.Biol (Paris) 42, 826-829.

DANTZER R. (1994) How do cytokines say hello to the brain? Neural versus humoral mediation. Eur.Cytokine Netw. 5, 271-273.

DE LUIGI A., TERRENI L., SIRONI M. \& DE SIMONI M.G. (1998) The sympathetic nervous system tonically inhibits peripheral interleukin-1beta and interleukin-6 induction by central lipopolysaccharide. Neuroscience 83, 1245-1250.

DERIJK R., VAN ROOIJEN N., TILDERS F.J., BESEDOVSKY H.O., DEL REY A. \& BERKENBOSCH F. (1991) Selective depletion of macrophages prevents pituitary-adrenal activation in response to subpyrogenic, but not to pyrogenic, doses of bacterial endotoxin in rats. Endocrinology 129, 330-338.

DERIJK R., MICHELSON D., KARP B., PETRIDES J., GALLIVEN E., DEUSTER P., PACIOTTI G., GOLD P.W. \& STERNBERG E.M. (1997) Exercise and circadian rhythm-induced variations in plasma cortisol differentially regulate interleukin-1 beta (IL-1 beta), IL-6, and tumor necrosis factor-alpha (TNF alpha) production in humans: high sensitivity of TNF alpha and resistance of IL-6. $J$ Clin.Endocrinol.Metab 82, 2182-2191.

DINARELLO C.A. (1996) Biologic basis for interleukin-1 in disease. Blood 87, 20952147.

DINARELLO C.A. (1997) Role of pro- and anti-inflammatory cytokines during inflammation: experimental and clinical findings. J Biol Regul.Homeost.Agents 11, 91-103.

DINARELLO C.A. (1997) Interleukin-1. Cytokine Growth Factor Rev. 8, 253-265.

DINARELLO C.A. (1997) Induction of interleukin-1 and interleukin-1 receptor antagonist. Semin.Oncol. 24, S9-S9

DINARELLO C.A. (1997) Proinflammatory and anti-inflammatory cytokines as mediators in the pathogenesis of septic shock. Chest 112, 321S-329S.

DOHERTY G.M., JENSEN J.C., BURESH C.M. \& NORTON J.A. (1992) Hormonal regulation of inflammatory cell cytokine transcript and bioactivity production in response to endotoxin. Cytokine 4, 55-62.

DUNN A.J. (1992) Endotoxin-induced activation of cerebral catecholamine and serotonin metabolism: comparison with interleukin-1. J Pharmacol.Exp.Ther. 261, 964-969. 
DUNN A.J. (1992) The role of interleukin-1 and tumor necrosis factor alpha in the neurochemical and neuroendocrine responses to endotoxin. Brain Res Bull. 29, 807-812.

ERIKSSON C., WINBLAD B. \& SCHULTZBERG M. (1998) Kainic acid induced expression of interleukin-1 receptor antagonist mRNA in the rat brain. Brain Res Mol.Brain Res 58, 195-208.

ERIKSSON C., VAN DAM A.M., LUCASSEN P.J., BOL J.G., WINBLAD B. \& SCHULTZBERG M. (1999) Immunohistochemical localization of interleukin1beta, interleukin-1 receptor antagonist and interleukin-1beta converting enzyme/caspase-1 in the rat brain after peripheral administration of kainic acid. Neuroscience 93, 915-930.

ESPINOZA J., ROMERO R., CHAIWORAPONGSA T., KIM J.C., YOSHIMATSU J., EDWIN S., RATHNASABAPATHY C., TOLOSA J., DONNENFELD A., CRAPARO F., GOMEZ R. \& BUJOLD E. (2002) Lipopolysaccharide-binding protein in microbial invasion of the amniotic cavity and human parturition. $J$ Matern.Fetal Neonatal Med. 12, 313-321.

EVANS R.J., BRAY J., CHILDS J.D., VIGERS G.P., BRANDHUBER B.J., SKALICKY J.J., THOMPSON R.C. \& EISENBERG S.P. (1995) Mapping receptor binding sites in interleukin (IL)-1 receptor antagonist and IL-1 beta by site-directed mutagenesis. Identification of a single site in IL-1ra and two sites in IL-1 beta. J Biol Chem. 270, 11477-11483.

FALKENBURG J.H., HARRINGTON M.A., WALSH W.K., DAUB R. \& BROXMEYER H.E. (1990) Gene-expression and release of macrophage-colony stimulating factor in quiescent and proliferating fibroblasts. Effects of serum, fibroblast growth-promoting factors, and IL-1. J Immunol. 144, 4657-4662.

FARRAR W.L., KILIAN P.L., RUFF M.R., HILL J.M. \& PERT C.B. (1987) Visualization and characterization of interleukin 1 receptors in brain. $J$ Immunol. 139, 459-463.

FENG Y.J., SHALTS E., XIA L.N., RIVIER J., RIVIER C., VALE W. \& FERIN M. (1991) An inhibitory effects of interleukin-1a on basal gonadotropin release in the ovariectomized rhesus monkey: reversal by a corticotropin-releasing factor antagonist. Endocrinology 128, 2077-2082.

FONG Y., MOLDAWER L.L., MARANO M., WEI H., BARBER A., MANOGUE K., TRACEY K.J., KUO G., FISCHMAN D.A., CERAMI A. \& . (1989) Cachectin/TNF or IL-1 alpha induces cachexia with redistribution of body proteins. Am J Physiol 256, R659-R665

FRIEDMAN W.J. (2001) Cytokines regulate expression of the type 1 interleukin-1 receptor in rat hippocampal neurons and glia. Exp.Neurol. 168, 23-31.

GAYLE D., ILYIN S.E., FLYNN M.C. \& PLATA-SALAMAN C.R. (1998) Lipopolysaccharide (LPS)- and muramyl dipeptide (MDP)-induced anorexia during refeeding following acute fasting: characterization of brain cytokine and neuropeptide systems mRNAs. Brain Res 795, 77-86. 
GIULIAN D., BAKER T.J., SHIH L.C. \& LACHMAN L.B. (1986) Interleukin 1 of the central nervous system is produced by ameboid microglia. J Exp.Med. 164, 594-604.

GOLDMAN J.M., COOPER R.L., EDWARDS T.L., REHNBERG G.L., MCELROY W.K. \& HEIN J.F. (1991) Suppression of the luteinizing hormone surge by chlordimeform in ovariectomized, steroid-primed female rats. Pharmacol.Toxicol. 68, 131-136.

GOW R.M., O'BRYAN M.K., CANNY B.J., OOI G.T. \& HEDGER M.P. (2001) Differential effects of dexamethasone treatment on lipopolysaccharide-induced testicular inflammation and reproductive hormone inhibition in adult rats. $J$ Endocrinol. 168, 193-201.

GRANOWITZ E.V., SANTOS A.A., POUTSIAKA D.D., CANNON J.G., WILMORE D.W., WOLFF S.M. \& DINARELLO C.A. (1991) Production of interleukin-1receptor antagonist during experimental endotoxaemia. Lancet 338, 1423-1424.

GRANOWITZ E.V., CLARK B.D., MANCILLA J. \& DINARELLO C.A. (1991) Interleukin-1 receptor antagonist competitively inhibits the binding of interleukin-1 to the type II interleukin-1 receptor. J Biol Chem. 266, 1414714150 .

GRAY G.D., MICKELSON M.M., HALL T.C. \& KESSEL D. (1972) Small lymphocyte phosphorylation of cytarabine--an organ and species survey. Biochem.Pharmacol. 21, 2227-2236.

HALL A.K. \& RAO M.S. (1992) Cytokines and neurokines: related ligands and related receptors. Trends Neurosci. 15, 35-37.

HANNUM C.H., WILCOX C.J., AREND W.P., JOSLIN F.G., DRIPPS D.J., HEIMDAL P.L., ARMES L.G., SOMMER A., EISENBERG S.P. \& THOMPSON R.C. (1990) Interleukin-1 receptor antagonist activity of a human interleukin-1 inhibitor. Nature 343, 336-340.

HAOUR F., MARQUETTE C., TSIANG H., BAN E., CRUMEYROLLE-ARIAS M., ROSTENE W. \& FILLION G. (1994) Interleukin-1 receptors in brain and pituitary. Characterization and modulation during infection and stress. Ann.N.Y.Acad.Sci. 741, 324-337.

HINZE-SELCH D., MULLER-PREUSS P. \& ZHANG Y. (1997) Cytokine secretion in squirrel monkeys. Psychoneuroendocrinology 22, 311-323.

HOPKINS S.J. \& ROTHWELL N.J. (1995) Cytokines and the nervous system. I: Expression and recognition. Trends Neurosci. 18, 83-88.

ILYIN S.E., GAYLE D., FLYNN M.C. \& PLATA-SALAMAN C.R. (1998) Interleukin-1beta system (ligand, receptor type I, receptor accessory protein and receptor antagonist), TNF-alpha, TGF-betal and neuropeptide Y mRNAs in specific brain regions during bacterial LPS-induced anorexia. Brain Res Bull. 45, 507-515. 
JOHNSON B.D. \& TRUITT R.L. (1992) A decrease in graft-vs.-host disease without loss of graft-vs.-leukemia reactivity after MHC-matched bone marrow transplantation by selective depletion of donor NK cells in vivo. Transplantation 54, 104-112.

JOHNSON J.D., O'CONNOR K.A., DEAK T., STARK M., WATKINS L.R. \& MAIER S.F. (2002) Prior stressor exposure sensitizes LPS-induced cytokine production. Brain Behav.Immun. 16, 461-476.

JOHNSON L.L., NORBERG B., WILLIS M.L., ZEBROSKI H. \& SWANSON P. (1997) Isolation, characterization, and radioimmunoassay of Atlantic halibut somatolactin and plasma levels during stress and reproduction in flatfish. Gen.Comp Endocrinol. 105, 194-209.

KAPCALA L.P., HE J.R., GAO Y., PIEPER J.O. \& DETOLLA L.J. (1996) Subdiaphragmatic vagotomy inhibits intra-abdominal interleukin-1 beta stimulation of adrenocorticotropin secretion. Brain Res 728, 247-254.

KELLER S.E., SCHLEIFER S.J., LIOTTA A.S., BOND R.N., FARHOODY N. \& STEIN M. (1988) Stress-induced alterations of immunity in hypophysectomized rats. Proc.Natl.Acad.Sci.U.S.A 85, 9297-9301.

KLASING K.C., LAURIN D.E., PENG R.K. \& FRY D.M. (1987) Immunologically mediated growth depression in chicks: influence of feed intake, corticosterone and interleukin-1. J Nutr. 117, 1629-1637.

KLIN B., BOLDUR I., HALEVY A., BARR J. \& VINOGRAD I. (1997) Bacteriology of cholelithiasis in infants and children. Surg.Laparosc.Endosc. 7, 137-139.

KOIKE K., MASUMOTO N., KASAHARA K., YAMAGUCHI M., TASAKA K., HIROTA K., MIYAKE A. \& TANIZAWA O. (1991) Tumor necrosis factoralpha stimulates prolactin release from anterior pituitary cells: a possible involvement of intracellular calcium mobilization. Endocrinology 128, 27852790 .

KRUEGER J.M. \& TOTH L.A. (1994) Cytokines as regulators of sleep. Ann.N.Y.Acad.Sci. 739, 299-310.

LAYE S., PARNET P., GOUJON E. \& DANTZER R. (1994) Peripheral administration of lipopolysaccharide induces the expression of cytokine transcripts in the brain and pituitary of mice. Brain Res Mol.Brain Res 27, 157-162.

LECHAN R.M., TONI R., CLARK B.D., CANNON J.G., SHAW A.R., DINARELLO C.A. \& REICHLIN S. (1990) Immunoreactive interleukin-1 beta localization in the rat forebrain. Brain Res 514, 135-140.

LEGAC E., VAUGIER G.L., BOUSQUET F., BAJELAN M. \& LECLERC M. (1996) Primitive cytokines and cytokine receptors in invertebrates: the sea star Asterias rubens as a model of study. Scand.J Immunol. 44, 375-380.

LIEBERMAN A.P., PITHA P.M., SHIN H.S. \& SHIN M.L. (1989) Production of tumor necrosis factor and other cytokines by astrocytes stimulated with 
lipopolysaccharide or a neurotropic virus. Proc.Natl.Acad.Sci.U.S.A 86, 63486352.

LIEBERMAN A.P., PITHA P.M. \& SHIN M.L. (1990) Protein kinase regulates tumor necrosis factor mRNA stability in virus-stimulated astrocytes. J Exp.Med. 172, 989-992.

LIU T., MCDONNELL P.C., YOUNG P.R., WHITE R.F., SIREN A.L., HALLENBECK J.M., BARONE F.C. \& FEURESTEIN G.Z. (1993) Interleukin-1 beta mRNA expression in ischemic rat cortex. Stroke 24, 17461750 .

LODDICK S.A., WONG M.L., BONGIORNO P.B., GOLD P.W., LICINIO J. \& ROTHWELL N.J. (1997) Endogenous interleukin-1 receptor antagonist is neuroprotective. Biochem.Biophys.Res Commun. 234, 211-215.

LUHESHI G.N., STEFFERL A., TURNBULL A.V., DASCOMBE M.J., BROUWER S., HOPKINS S.J. \& ROTHWELL N.J. (1997) Febrile response to tissue inflammation involves both peripheral and brain IL-1 and TNF-alpha in the rat. Am J Physiol 272, R862-R868

LYNCH M.A. (2002) Interleukin-1 beta exerts a myriad of effects in the brain and in particular in the hippocampus: analysis of some of these actions. Vitam.Horm. 64, 185-219.

MANTOVANI A., LOCATI M., VECCHI A., SOZZANI S. \& ALLAVENA P. (2001) Decoy receptors: a strategy to regulate inflammatory cytokines and chemokines. Trends Immunol. 22, 328-336.

MCFARLAND H.I., LOBITO A.A., JOHNSON M.M., PALARDY G.R., YEE C.S., JORDAN E.K., FRANK J.A., TRESSER N., GENAIN C.P., MUELLER J.P., MATIS L.A. \& LENARDO M.J. (2001) Effective antigen-specific immunotherapy in the marmoset model of multiple sclerosis. J Immunol. 166, 2116-2121.

MERRILL J.E. \& CHEN I.S. (1991) HIV-1, macrophages, glial cells, and cytokines in AIDS nervous system disease. FASEB J 5, 2391-2397.

MERRILL J.E. (1991) Effects of interleukin-1 and tumor necrosis factor-alpha on astrocytes, microglia, oligodendrocytes, and glial precursors in vitro. Dev.Neurosci. 13, 130-137.

MERRILL J.E. (1992) Proinflammatory and antiinflammatory cytokines in multiple sclerosis and central nervous system acquired immunodeficiency syndrome. $J$ Immunother. 12, 167-170.

MINAMI M., KURAISHI Y., YAMAGUCHI T., NAKAI S., HIRAI Y. \& SATOH M. (1990) Convulsants induce interleukin-1 beta messenger RNA in rat brain. Biochem.Biophys.Res Commun. 171, 832-837.

MINAMI M., KURAISHI Y. \& SATOH M. (1991) Effects of kainic acid on messenger RNA levels of IL-1 beta, IL-6, TNF alpha and LIF in the rat brain. Biochem.Biophys.Res Commun. 176, 593-598. 
MINAMI M., KURAISHI Y., YAMAGUCHI T., NAKAI S., HIRAI Y. \& SATOH M. (1991) Immobilization stress induces interleukin-1 beta mRNA in the rat hypothalamus. Neurosci.Lett. 123, 254-256.

MINAMI M., KURAISHI Y., YABUUCHI K., YAMAZAKI A. \& SATOH M. (1992) Induction of interleukin-1 beta mRNA in rat brain after transient forebrain ischemia. J Neurochem. 58, 390-392.

MULLIS K., FALOONA F., SCHARF S., SAIKI R., HORN G. \& ERLICH H. (1992) Specific enzymatic amplification of DNA in vitro: the polymerase chain reaction. 1986. Biotechnology 24, 17-27.

NAGY E. \& BERCZI I. (1991) Hypophysectomized rats depend on residual prolactin for survival. Endocrinology 128, 2776-2784.

NASHAN D. \& LUGER T.A. (1999) [Interleukin 1. 1: Basic principles and pathophysiology]. Hautarzt 50, 680-688.

NASHAN D. \& LUGER T.A. (1999) [Interleukin 1. Part 2: Mode of action and therapeutic possibilities]. Hautarzt 50, 756-763.

O'BRYAN M.K., SCHLATT S., PHILLIPS D.J., DE KRETSER D.M. \& HEDGER M.P. (2000) Bacterial lipopolysaccharide-induced inflammation compromises testicular function at multiple levels in vivo. Endocrinology 141, 238-246.

OHLSSON K., BJORK P., BERGENFELDT M., HAGEMAN R. \& THOMPSON R.C. (1990) Interleukin-1 receptor antagonist reduces mortality from endotoxin shock. Nature 348, 550-552.

OKUDA Y., BARDIN C.W., HODGSKIN L.R. \& MORRIS P.L. (1995) Interleukins-1 alpha and -1 beta regulate interleukin-6 expression in Leydig and Sertoli cells. Recent Prog.Horm.Res 50 , 367-372.

OPP M.R. \& KRUEGER J.M. (1994) Interleukin-1 is involved in responses to sleep deprivation in the rabbit. Brain Res 639, 57-65.

PARNET P., AMINDARI S., WU C., BRUNKE-REESE D., GOUJON E., WEYHENMEYER J.A., DANTZER R. \& KELLEY K.W. (1994) Expression of type I and type II interleukin-1 receptors in mouse brain. Brain Res Mol.Brain Res 27, 63-70.

PAUL W.E. \& SEDER R.A. (1994) Lymphocyte responses and cytokines. Cell 76, 241-251.

PEARSON V.L., ROTHWELL N.J. \& TOULMOND S. (1999) Excitotoxic brain damage in the rat induces interleukin-1beta protein in microglia and astrocytes: correlation with the progression of cell death. Glia 25, 311-323.

PLATA-SALAMAN C.R. (1998) Cytokines and Feeding. News Physiol Sci. 13, 298304. 
PRYCE C.R., PALME R. \& FELDON J. (2002) Development of pituitary-adrenal endocrine function in the marmoset monkey: infant hypercortisolism is the norm. J Clin.Endocrinol.Metab 87, 691-699.

RAMACHANDRA R.N., BERCZI A., SEHON A.H. \& BERCZI I. (1993) Inhibition of lip. J Infect.Dis. 167, 1151-1159.

REDL H., SCHLAG G. \& BAHRAMI S. (1998) Animal models of sepsis and shock: a review and lessons learned. Edwin A Deitch. Shock 9(1):1-11, 1998. Shock 10, $442-445$.

REFOJO D., ARIAS P., MOGUILEVSKY J.A. \& FELEDER C. (1998) Effect of bacterial endotoxin on in vivo pulsatile gonadotropin secretion in adult male rats. Neuroendocrinology 67, 275-281.

REYES T.M. \& COE C.L. (1998) The proinflammatory cytokine network: interactions in the CNS and blood of rhesus monkeys. Am J Physiol 274, R139-R144

RIVEST S. \& RIVIER C. (1995) The role of corticotropin-releasing factor and interleukin-1 in the regulation of neurons controlling reproductive functions. Endocr.Rev. 16, 177-199.

RIVIER C., CHIZZONITE R. \& VALE W. (1989) In the mouse, the activation of the hypothalamic-pituitary-adrenal axis by a lipopolysaccharide (endotoxin) is mediated through interleukin-1. Endocrinology 125, 2800-2805.

ROTHWELL N.J. \& HOPKINS S.J. (1995) Cytokines and the nervous system II: Actions and mechanisms of action. Trends Neurosci. 18, 130-136.

ROTHWELL N.J. \& LUHESHI G.N. (2000) Interleukin 1 in the brain: biology, pathology and therapeutic target. Trends Neurosci. 23, 618-625.

SABATTINI E., BISGAARD K., ASCANI S., POGGI S., PICCIOLI M., CECCARELLI C., PIERI F., FRATERNALI-ORCIONI G. \& PILERI S.A. (1998) The EnVision++ system: a new immunohistochemical method for diagnostics and research. Critical comparison with the APAAP, ChemMate, CSA, LABC, and SABC techniques. J Clin.Pathol. 51, 506-511.

SCHREUDER H., TARDIF C., TRUMP-KALLMEYER S., SOFFIENTINI A., SARUBBI E., AKESON A., BOWLIN T., YANOFSKY S. \& BARRETT R.W. (1997) A new cytokine-receptor binding mode revealed by the crystal structure of the IL-1 receptor with an antagonist. Nature 386, 194-200.

SCHWARTZ G.J., PLATA-SALAMAN C.R. \& LANGHANS W. (1997) Subdiaphragmatic vagal deafferentation fails to block feeding-suppressive effects of LPS and IL-1 beta in rats. Am J Physiol 273, R1193-R1198

SEDLACEK H. H. \& MÖRÖY T. (1995) Immune reaction. Springer-Verlag

SEGGIE J.A. \& BROWN G.M. (1975) Stress response patterns of plasma corticosterone, prolactin, and growth hormone in the rat, following handling or exposure to novel environment. Can.J Physiol Pharmacol. 53, 629-637. 
SHARMA A.C., BOSMANN H.B., MOTEW S.J., HALES K.H., HALES D.B. \& FERGUSON J.L. (1996) Steroid hormone alterations following induction of chronic intraperitoneal sepsis in male rats. Shock 6, 150-154.

SHARMA A.C., SAM A.D., LEE L.Y., HALES D.B., LAW W.R., FERGUSON J.L. \& BOSMANN H.B. (1998) Effect of NG-nitro-L-arginine methyl ester on testicular blood flow and serum steroid hormones during sepsis. Shock 9, 416421.

SHENG J.G., GRIFFIN W.S., ROYSTON M.C. \& MRAK R.E. (1998) Distribution of interleukin-1-immunoreactive microglia in cerebral cortical layers: implications for neuritic plaque formation in Alzheimer's disease. Neuropathol.Appl.Neurobiol. 24, 278-283.

SIMS J.E., GAYLE M.A., SLACK J.L., ALDERSON M.R., BIRD T.A., GIRI J.G., COLOTTA F., RE F., MANTOVANI A., SHANEBECK K. \& . (1993) Interleukin 1 signaling occurs exclusively via the type I receptor. Proc.Natl.Acad.Sci.U.S.A 90, 6155-6159.

SIMS J.E. \& DOWER S.K. (1994) Interleukin-1 receptors. Eur.Cytokine Netw. 5, 539546.

SLACK J., MCMAHAN C.J., WAUGH S., SCHOOLEY K., SPRIGGS M.K., SIMS J.E. \& DOWER S.K. (1993) Independent binding of interleukin-1 alpha and interleukin-1 beta to type I and type II interleukin-1 receptors. J Biol Chem. 268, 2513-2524.

SMITH D.E., KETCHEM R.R., MOORE H., ANDERSON Z., RENSHAW B.R., FRIEND D.J. \& SIMS J.E. (2002) A single amino acid difference between human and monkey interleukin (IL)-1beta dictates effective binding to soluble type II IL-1 receptor. J Biol Chem. 277, 47619-47625.

SONG C. \& LEONARD B.E. (1995) Interleukin-2-induced changes in behavioural, neurotransmitter, and immunological parameters in the olfactory bulbectomized rat. Neuroimmunomodulation. 2, 263-273.

SPINEDI E., HADID R., DANEVA T. \& GAILLARD R.C. (1992) Cytokines stimulate the $\mathrm{CRH}$ but not the vasopressin neuronal system: evidence for a median eminence site of interleukin-6 action. Neuroendocrinology 56, 46-53.

STEPHAN H., BARON G. \& SCHWERDTFEGER W.K. (1980) The Brain of the Common Marmoset. Springer-Verlag

STERNBERG E.M. (1997) Neural-immune interactions in health and disease. $J$ Clin.Invest 100, 2641-2647.

STRAUB R.H., VOGL D., GROSS V., LANG B., SCHOLMERICH J. \& ANDUS T. (1998) Association of humoral markers of inflammation and dehydroepiandrosterone sulfate or cortisol serum levels in patients with chronic inflammatory bowel disease. Am J Gastroenterol. 93, 2197-2202.

SZELENYI J. (2001) Cytokines and the central nervous system. Brain Res Bull. 54, 329-338. 
TADA M., DISERENS A.C., DESBAILLETS I., JAUFEERALLY R., HAMOU M.F. \& DE TRIBOLET N. (1994) Production of interleukin-1 receptor antagonist by human glioblastoma cells in vitro and in vivo. J Neuroimmunol. 50, 187-194.

TAKAO T., CULP S.G., NEWTON R.C. \& DE SOUZA E.B. (1992) Type I interleukin-1 receptors in the mouse brain-endocrine-immune axis labelled with [125I]recombinant human interleukin-1 receptor antagonist. J Neuroimmunol. 41, 51-60.

TANEBE K., NISHIJO H., MURAGUCHI A. \& ONO T. (2000) Effects of chronic stress on hypothalamic Interleukin-1beta, interleukin-2, and gonadotrophinreleasing hormone gene expression in ovariectomized rats. J Neuroendocrinol. 12, 13-21.

VILLINGER F., BRAR S.S., MAYNE A., CHIKKALA N. \& ANSARI A.A. (1995) Comparative sequence analysis of cytokine genes from human and nonhuman primates. J Immunol. 155, 3946-3954.

VITKOVIC L., KONSMAN J.P., BOCKAERT J., DANTZER R., HOMBURGER V. \& JACQUE C. (2000) Cytokine signals propagate through the brain. Mol.Psychiatry 5, 604-615.

VITKOVIC L., BOCKAERT J. \& JACQUE C. (2000) "Inflammatory" cytokines: neuromodulators in normal brain? J Neurochem. 74, 457-471.

WAKABAYASHI G., GELFAND J.A., BURKE J.F., THOMPSON R.C. \& DINARELLO C.A. (1991) A specific receptor antagonist for interleukin 1 prevents Escherichia coli-induced shock in rabbits. FASEB J 5, 338-343.

WALLGREN M., KINDAHL H. \& RODRIGUEZ-MARTINEZ H. (1993) Alterations in testicular function after endotoxin injection in the boar. Int.J Androl 16, 235243.

WALTON P.E. \& CRONIN M.J. (1990) Tumor necrosis factor-alpha and interferongamma reduce prolactin release in vitro. Am J Physiol 259, E672-E676

WEBEL D.M., FINCK B.N., BAKER D.H. \& JOHNSON R.W. (1997) Time course of increased plasma cytokines, cortisol, and urea nitrogen in pigs following intraperitoneal injection of lipopolysaccharide. J Anim Sci. 75, 1514-1520.

WEIGENT D.A. (1996) Immunoregulatory properties of growth hormone and prolactin. Pharmacol.Ther. 69, 237-257.

WERLING D., SUTTER F., ARNOLD M., KUN G., TOOTEN P.C., GRUYS E., KREUZER M. \& LANGHANS W. (1996) Characterisation of the acute phase response of heifers to a prolonged low dose infusion of lipopolysaccharide. Res Vet.Sci. 61, 252-257.

WILEY C.A., GRAFE M., KENNEDY C. \& NELSON J.A. (1988) Human immunodeficiency virus (HIV) and JC virus in acquired immune deficiency syndrome (AIDS) patients with progressive multifocal leukoencephalopathy. Acta Neuropathol.(Berl) 76, 338-346. 
WONG H.L., COSTA G.L., LOTZE M.T. \& WAHL S.M. (1993) Interleukin (IL) 4 differentially regulates monocyte IL-1 family gene expression and synthesis in vitro and in vivo. J Exp.Med. 177, 775-781.

WONG M.L. \& LICINIO J. (1994) Localization of interleukin 1 type I receptor mRNA in rat brain. Neuroimmunomodulation. 1, 110-115.

XIAO E., XIA-ZHANG L., BARTH A., ZHU J. \& FERIN M. (1998) Stress and the menstrual cycle: relevance of cycle quality in the short- and long-term response to a 5-day endotoxin challenge during the follicular phase in the rhesus monkey. J Clin.Endocrinol.Metab 83, 2454-2460.

XIAO E., XIA L., FERIN M. \& WARDLAW S.L. (1999) Intracerebroventricular injection of interleukin-1 stimulates the release of high levels of interleukin-6 and interleukin-1 receptor antagonist into peripheral blood in the primate. $J$ Neuroimmunol. 97, 70-76.

XIAO E., XIA-ZHANG L. \& FERIN M. (1999) Stress and the menstrual cycle: s. $J$ Clin.Endocrinol.Metab 84, 623-626.

XIAO E., XIA-ZHANG L. \& FERIN M. (2000) Inhibitory effects of endotoxin on LH secretion in the ovariectomized monkey are prevented by naloxone but not by an interleukin-1 receptor antagonist. Neuroimmunomodulation. 7, 6-15.

XIAO E., XIA-ZHANG L., VULLIEMOZ N.R., FERIN M. \& WARDLAW S.L. (2003) Agouti-Related Protein Stimulates the Hypothalamic-Pituitary-Adrenal (HPA) Axis and Enhances the HPA Response to Interleukin-1 in the Primate. Endocrinology 144, 1736-1741.

YABUUCHI K., MINAMI M., KATSUMATA S. \& SATOH M. (1994) Localization of type I interleukin-1 receptor mRNA in the rat brain. Brain Res Mol.Brain Res 27, 27-36.

YABUUCHI K., MINAMI M., KATSUMATA S., YAMAZAKI A. \& SATOH M. (1994) An in situ hybridization study on interleukin-1 beta mRNA induced by transient forebrain ischemia in the rat brain. Brain Res Mol.Brain Res 26, 135142.

YASUHARA O., MATSUO A., TERAI K., WALKER D.G., BERGER A.E., AKIGUCHI I., KIMURA J. \& MCGEER P.L. (1997) Expression of interleukin1 receptor antagonist protein in post-mortem human brain tissues of Alzheimer's disease and control cases. Acta Neuropathol.(Berl) 93, 414-420.

YU A.C. \& LAU L.T. (2000) Expression of interleukin-1 alpha, tumor necrosis factor alpha and interleukin-6 genes in astrocytes under ischemic injury. Neurochem.Int. 36, 369-377.

ZOLI A., FERLISI E.M., LIZZIO M., ALTOMONTE L., MIRONE L., BARINI A., SCUDERI F., BARTOLOZZI F. \& MAGARO M. (2002) Prolactin/cortisol ratio in rheumatoid arthritis. Ann.N.Y.Acad.Sci. 966, 508-512. 


\section{$7 \quad$ Anhang}

\subsection{Geräte und Verbrauchsmaterialien}

- $\quad$ ABI PRISM ${ }^{\mathrm{TM}} 7700$

Sequence Detektion System 7700 SDS

- BD Vacutainer

- Blöckchenformen

- DAKO TechMate ${ }^{\mathrm{TM}}$ Horizon 500

- DAKO ChemMate ${ }^{\mathrm{TM}}$ Capillary Gap Microscope Slides $(75 \mu \mathrm{m})$ for TechMate ${ }^{\mathrm{TM}} 500 / 1000$

- Deckgläschen 18x18mm

- ELISA-Reader

- ELISA-Washer

- Flurometer Versa Fluor ${ }^{\mathrm{TM}}$ Flurometer

- Friomobil No.1206

- Gammacounter No. 1470 Wizard

- Gewebeinfiltrationsautomat

- Kodak Kamera und Software ds/Digital science Version 2.0.3.

- Kühlplatte

- Kühlzentrifuge Sepatech Biofuge 15R

- MicroOptical 96-well reaktion Plate

- MicroOptical Caps

- Mikroreaktionsgefäße (E-Cups)

- Mikroskop Nikon Eclipse E 600

- Mikroskop-Kamera und Programm
PE Applied

Biosystems

$\mathrm{BD}$

Leica

DakoCytomation

DakoCytomation \&

BioTek Solutions

Menzel-Gläser

Tecan

Tecan

BIO-RAD

Reichert-Jung

Wallac

Leica

Eastman Kodak Company

Leica

Heraeus Instruments

Sarsted

Sarsted

Sarsted

Nikon

Zeiss AxioCam und AxioVision Programm Version 3.0.6 SP4

- Mikrotom RM

Leica

- Mikrotomklingen Model $819^{\circledR}$

Leica

- Nylon Membranen positiv geladen Nr. 1209272

Roche

- Objektträger SuperForst ${ }^{\circledR}$ Plus

Menzel-Gläser 
- Paraffinausgießstation Leica EG 1160

- Photometer

- Pipetten

- Reagenziengefäße für TechMate ${ }^{\mathrm{TM}} \mathrm{Nr}$. S2039

- Saugkissen für TechMate ${ }^{\mathrm{TM}}$ Nr. S2043

- Schüttler Vibax

- Spannungsblock Power Pack P25

- Thermocycler Biometra ${ }^{\circledR}$ TRIO-Thermoblock Biometra $^{\circledR}$ Thermocycler T3

- Thermomixer 5436

- Tubes

- Ultraschallbad Sonifer B-12 Cell Disrupter

- Vortexgerät Vortex Genie $2^{\mathrm{TM}}$

- Wärmeplatte H11220

- Wärmeschrank Function Line

- Zerntrifugen Microcentifuge MC-13
Leica

Amersham Pharmacia

GeneQuant

Eppendorf

DakoCytomation

DakoCytomation

Serono Diagnostics

Biometra

Biometra

Biometra

Eppendorf

Sarsted

Branson Sonic Power

Company

Vortex

Leica

Heraeus Instruments

amicon

Eppendorf Zentrifuge 5413

Hettich Rotixa RP Zentrifuge

\subsection{Verwendete Kits}

- DAKOChemMate ${ }^{\mathrm{TM}}$ EnVision ${ }^{\mathrm{TM}}$ Detektion Kit

DakoCytomation Perxoidase/DAB + Anti Maus/Kaninchen Nr. K5007

- DAKO GenPoint ${ }^{\mathrm{TM}}$ Nr. K0620 DakoCytomation

- Dako EnVision $^{\mathrm{TM}}+$ HRP, Anti-Maus, DAB+ Nr. K4007 DakoCytomation

- DIG Nucleic Acid Detektion Kit Nr. 1175041 Roche

- ELISA-Kit zur Bestimmung von human IL-6 EASIA-Kit KAC1261

BIOSOURCE $^{\circledR}$

- $\quad$ ELISA-Kit zur Bestimmung von human IL-1 $\beta$ Quantikine ${ }^{\circledR} \mathrm{HS}$ human IL-1 $\beta$ Immunoassay HSLB 50 R\&D Systems ${ }^{\circledR}$ 
- ELISA-Kit zu Bestimmung von Rhesus-Monkey TNF- $\alpha$ mkTNF- $\alpha$ ELISA-Kit KPC3012/KPC3011

BIOSOURCE $^{\circledR}$

- IRMA-Kit zur Bestimmung von Prolaktin

DSL-4500

$\mathrm{DSL}^{\circledR}$

- QIAfilter Plasmid Midi Kit Nr.12245

Qiagen

- RIA-Kit zur Bestimmung von Testosteron:

DSL-4100

$\mathrm{DSL}^{\circledR}$

- RIA-Kit zur Bestimmung von Cortisol

DSL-2000

$\mathrm{DSL}^{\circledR}$

- RiboGreen RNA Quantitation Kit Nr. R-11491/R-11490

Molecular Probes

- RiboMAX $^{\mathrm{TM}}$ SP6-Polymerase Nr. P1280

Promega

- RiboMAX $^{\mathrm{TM}}$ T7-Polymerase Nr. P1300

Promega

- $\quad$ RNeasy ${ }^{\circledR}$ Kit Nr. 74106

Qiagen

- $\quad$ TOPO TA Cloning Kit Nr.K4600-01

Invitrogen

- ULYSIS $^{\circledR}$ Biotin Markierungs-Kit Nr. ULK001

DakoCytomation \&

Kreatech

- Wizard $^{\mathrm{TM}}$-DNA-Clean-Up-Kit Nr. A713A

Promega

\subsection{Chemikalien und Reagenzien}

- Agarose

GibcoBRL $^{\circledR}$

- Agarose $1.5 \%$ ig: 6 g Agarose

auf $400 \mathrm{ml}$ 1x TBE-Puffer

- Ampicillin

Sigma

- Ampuwa

Braun

- Anti-dig-AP Fab-Fragmente Nr. 1093274

Roche

- Antikörper:

polyclonal-rabbit-anti-human-IL-1 $\beta \mathrm{Nr}$. sc-7884

SantaCruz

monoclonal-mouse-anti-human-IL-1 $\beta$ Nr. AF-201-NA

R\&DSystems

monoclonal-mouse-anti-human-IL-1ra Nr. AF-280-NA

R\&DSystems

monoclonal-mouse-anti-human-IL-1RI Nr. AF269

R\&DSystems

monoclonal-mouse-anti-human-IL-1RII Nr. AF-201-NA

R\&DSystems 
monoclonal-mouse-anti-human-NSE (gebrauchsfertig)

DakoCytomation

Nr. H7092

monoclonal-mouse-anti-human-NSE Nr. M0873

DakoCytomation

monoclonal-mouse-anti-human-GFAP Nr. M0761

DakoCytomation

polyclonal-rabbit-anti-cow-GFAP (gebrauchsfertig)

DakoCytomation

Nr. H0083

- Antikörperverdünnungsmedium (gebrauchsfertig) Nr. S3022 DakoCytomation

- $\quad$ BCIP Nr. 1383221

Roche

5-Bromo-4-chloro-3-indolyl-phosphate, 4-Toluidin-Salz

- Blocking-Reagenz Nr. 1096176

Roche

- Blocking-Stammlösung 10\%: 10 g Blocking-Reagenz

in $100 \mathrm{ml}$ Maleinsäurepuffer lösen

autoklavieren

in Aliquots bei $-20^{\circ} \mathrm{C}$ lagern

- Borsäure Nr. B-0394

Sigma

- DAKO ChemMate ${ }^{\mathrm{TM}}$ Antikörperverdünnungsmittel

DakoCytomation Nr. S2022

- DAKO ChemMate ${ }^{\mathrm{TM}}$ Hematoxylin Nr. S2020

DakoCytomation

- DAKO ChemMate ${ }^{\mathrm{TM}}$ Peroxidase-Blocking Solution

DakoCytomation Nr. S2023

- DAKO ChemMate ${ }^{\mathrm{TM}}$ Puffer Kit Nr. K5006

DakoCytomation

- DAB Plus-Substratlösung Nr. K3468

DakoCytomation

- Deionisiertes Formamid: $50 \mathrm{ml}$ Formamid

+ mit $5 \mathrm{~g}$ Ionenaustauscher Serdolit

60 min auf rühren, $2 x$ filtern

- DePeX Nr. 361254D

Paesel \& Lorei

- DNA-Längenstandard

GibcoBRL

- DNA-Längenstandard: $50 \mu 1$ Ladder

$$
\begin{aligned}
& +450 \mu 1 \text { bidest. Wasser } \\
& +100 \mu 1 \text { Stopmix }
\end{aligned}
$$

- dNTP Mix 10 mM Nr. 18427-013

Invitrogen

- $\quad$ DIG Easy Hyb Nr. 1603558

Roche

- DIG RNA Labeling Mix Nr. 1277073

Roche

- EDTA 0,5 M pH 8.0 Nr. 15575-038

GibcoBRL $^{\circledR}$ 
- $\quad$ Eosin Nr. 1345

Merck

- Ethanol Nr.1.00983.1000

Merck

- Ethydiumbromid

Amresco

- Ethydiumbromidbad: $50 \mu 1$ Ethydiumbromid auf $750 \mathrm{ml}$ bidest. Wasser

- Formaldehyd 37\% Nr.1.04003.1000

Merck

- Formamid Nr. F 7503

Sigma

- Hämatoxylin nach Mayer Nr. 1.09249.05000

Merck

- Hybridisierungspuffer (gebrauchsfertig) Nr. S3304

DakoCytomation

- Isopropanol

J.T.Baker

- Kaliumchlorid (KCl ) Nr. 4936.1000

Merck

- Kaliumdihydrogensposphat $\mathrm{KH}_{2} \mathrm{PO} 4 \mathrm{Nr} .4873$

Merck

- Lithiumchlorid (LiCl) Nr. L-8895

Sigma

- Lithiumchlorid-Lösung 4M: $17 \mathrm{~g} \mathrm{LiCl}$ auf $100 \mathrm{ml}$ Velc. $-\mathrm{H}_{2} \mathrm{O}$

- Magnesiumchlorid $\left(\mathrm{MgCl}_{2}\right)$ Nr. 8.14733.0500

Merck

- Magnesiumchlorid-Lösung $1 \mathrm{M}: 101,7 \mathrm{~g} \mathrm{MgCl}_{2} \cdot 6 \mathrm{H}_{2} \mathrm{O}$ in $400 \mathrm{~mL}$ bidest. Wasser lösen ad $500 \mathrm{ml}$ bidest.Wasser $+0,5 \mathrm{ml}$ Velcorin, autoklavieren

- Maleinsäure Nr. 800380.0500

Merck

- Maleinsäurepuffer: $\quad$ 5,8g Maleinsäure

$+4,38 \mathrm{~g} \mathrm{NaCl}$

in $400 \mathrm{ml}$ bidest.Wasser lösen

mit $\mathrm{NaOH}$ auf $\mathrm{pH}$ 7,5 einstellen ad $500 \mathrm{ml}$ bidest.Wasser

$+0,5 \mathrm{ml}$ Velcorin, autoklavieren

- Methanol Nr. 1.06009.1000

Merck

- M-MLV Reverse Transcriptase Nr. M3682

Promega

- MOPS Nr. $120 \mathrm{~K} 5400$

Sigma 3-(N-Morpholino)propanesulfonic acid

- MOPS-Puffer: 20.6g MOPS in $800 \mathrm{ml} 50 \mathrm{mM} \mathrm{NaAc}$ 


$$
\begin{aligned}
& \text { auf pH } 7.0 \text { einstellen } \\
& +10 \mathrm{ml} 0.5 \mathrm{~m} \text { EDTA pH } 8.0
\end{aligned}
$$

- Natriumacetat Nr. 1.06268.0250

Merck

- Natriumchlorid ( $\mathrm{NaCl}) \mathrm{Nr} .0278$

- Natriumchlorid-Lösung $5 \mathrm{M}$ : $146,1 \mathrm{~g} \mathrm{NaCl}$ in 400 bidest.Wasser lösen ad $500 \mathrm{ml}$ bidest.Wasser $+0,5 \mathrm{ml}$ Velcorin, autoklavieren

- Natriumcitrat Nr. S4641

- di-Natriumhydrogenphosphat $\left(\mathrm{Na}_{2} \mathrm{HPO}_{4}\right) \mathrm{Nr} .106586$

- $\quad$ NBT Nr. 1383213

Nitroblautetrazoliumchlorid

- $\quad$ NTM-Puffer: $5 \mathrm{~mL} 1 \mathrm{M}$ Tris pH 9,5 (100 mM)

$$
\begin{aligned}
& +1 \mathrm{~mL} 5 \mathrm{M} \mathrm{NaCl}(100 \mathrm{mM}) \\
& +2.5 \mathrm{~mL} 1 \mathrm{M} \mathrm{MgCl}_{2}(50 \mathrm{mM}) \\
& \text { ad } 50 \mathrm{~mL} \text { Velc.-Wasser }
\end{aligned}
$$

- Oligo(dt)Primer Nr. 18418-012

- Paraformaldehyd Nr. 8.18715.0100

- Paraffin Polarit TW56/58 Nr. 10054

- PCR-Supermix

- Peroxidase-Blockingreagenz (gebrauchsfertig) Nr. S2001

- PBS 10x 1M: $5,75 \mathrm{~g} \mathrm{Na}_{2} \mathrm{HPO}_{4}$

$$
\begin{aligned}
& +1 \mathrm{~g} \mathrm{KH}_{2} \mathrm{PO}_{4} \\
& +40 \mathrm{~g} \mathrm{NaCl} \\
& +1 \mathrm{~g} \mathrm{KCl} \\
& \text { ad } 500 \mathrm{ml} \text { bidest. Wasser } \\
& +0,5 \mathrm{ml} \text { Velcorin, autoklavieren }
\end{aligned}
$$

- Proteinase K (gebrauchsfertig) Nr. S3020

DakoCytomation

- RNAse A Invitrogen

- RNAse T1 Promega
Sigma

Merck

Roche
GibcoBRL $^{\circledR}$

Merck

Süsse

Life Technologies

DakoCytomation

- RNAse-Puffer: $15 \mathrm{ml}$ 1M Tris-HCL pH 8.0

$$
\begin{aligned}
& +150 \mathrm{ml} 5 \mathrm{M} \mathrm{NaCl} \\
& +3 \mathrm{ml} 0.5 \mathrm{M} \text { EDTA } \\
& +6 \mathrm{ml} \text { RNAse A }(10 \mathrm{mg} / \mathrm{ml})
\end{aligned}
$$




$$
\begin{aligned}
& +10 \mu 1 \text { RNAse T1 } \\
& \text { ad } 1.51 \text { bidest. Wasser }
\end{aligned}
$$

- RNAsin $^{\circledR} \mathrm{Nr}$. N2511

Promega

- Salzsäure (HCl) Nr. 1.00317.1000

Merck

- SDS Nr. 15553-035

$\mathrm{GibcoBRL}^{\circledR}$

- SDS 10\%: 10 g SDS

auf $100 \mathrm{ml}$ Velc. $\mathrm{H}_{2} \mathrm{O}$

- Serdolit MB- 1pA Ionenaustauscher Nr. 40701

Serva

- $\quad$ SP6 RNA Polymerase Nr. P1085

Promega

- $\quad$ Spe I (Enzym) Nr. R6591

Promega

- $\quad$ SSC 20x pH 7.0: $87.65 \mathrm{~g} \mathrm{NaCl}$

$$
\begin{aligned}
& +44.1 \mathrm{~g} \text { Na-Citrat } \\
& \text { in } 400 \mathrm{ml} \text { bidest. Wasser lösen } \\
& \text { mit } 2 \mathrm{M} \text { Zitronensäure auf } \mathrm{pH} 7.0 \\
& \text { ad } 500 \mathrm{ml} \text { bidest. Wasser } \\
& +0.5 \mathrm{ml} \text { Velcorin, autoklavieren }
\end{aligned}
$$

- TAE $50 \mathrm{x}: 242 \mathrm{~g}$ Tris base

$+57,1 \mathrm{ml}$ Eisessig

$+100 \mathrm{ml}$ 0,5 M EDTA

ad 11 bidest. Wasser

- TaqMan Universal PCR Mastermix

PE Applied

Biosystems

- $\quad$ Target Retrieval Solution (10x, gebrauchsfertig) Nr. S1699

- TBE $20 \mathrm{x}$ : $108 \mathrm{~g}$ Tris

$$
\begin{aligned}
& +55 \text { g Borsäure } \\
& +40 \mathrm{ml} \text { 0,5 M EDTA } \\
& \text { ad } 11 \text { bidest. Wasser }
\end{aligned}
$$

- TBS 10x: $61 \mathrm{~g}$ Tris ultrarein

$+88 \mathrm{~g} \mathrm{NaCl}$

$+370 \mathrm{ml} 1 \mathrm{M} \mathrm{HCl}$

- TBST:

$125 \mathrm{ml} 1 \mathrm{M}$ Tris- $\mathrm{HCl} \mathrm{pH} 7.5$

$$
\begin{aligned}
& +45 \mathrm{~g} \mathrm{NaCl} \\
& +5 \mathrm{ml} \text { Tween-20 } \\
& \text { ad } 500 \mathrm{ml} \text { bidest. Wasser }
\end{aligned}
$$


$+0.5 \mathrm{ml}$ Velcorin, autoklavieren

- $\quad$ TissueTek ${ }^{\circledR}$ O.C.T. ${ }^{\mathrm{TM}}$ Compound Nr. 4583

Sakura

- Tris ultrarein Nr. 100840

Paesel \& Lorei

- Tris-HCl 1M: $\quad 60.5$ Tris

in $400 \mathrm{ml}$ bidest. Wasser lösen

pH mit konz. $\mathrm{HCl}$ einstellen

Für pH 7.4 ca. 35 ml konz. $\mathrm{HCl}$

Für pH 7.6 ca. $30 \mathrm{ml}$ konz. $\mathrm{HCl}$

Für pH 8.0 ca. $20 \mathrm{ml}$ konz. $\mathrm{HCl}$

ad $500 \mathrm{ml}$ bidest. Wasser

$+0.5 \mathrm{ml}$ Velcorin, autoklavieren

- Trypsin Nr. S2012

DakoCytomation

- Tween 20 Nr. P-1379

Sigma

- Velcorin E242

Bayer Leverkusen

- Velcorin- $\mathrm{H}_{2} \mathrm{O}: \quad 0,5 \mathrm{~mL}$ Velcorin

auf $500 \mathrm{~mL}$ bidest. Wasser

mind. $4 \mathrm{~h}$ stehen lassen und dann autoklavieren

- Wasserstoffperoxid $\left(\mathrm{H}_{2} \mathrm{O}_{2}\right) \mathrm{Nr}$. 1.07209.1000

Merck

- Zitronensäure Nr. 244

Merck

- Zitronensäure-Lösung 2M: $\quad 42,03$ g Zitronensäure

auf $50 \mathrm{ml} \mathrm{Velc.}-\mathrm{H}_{2} \mathrm{O}$ 


\subsection{Maschinenprotokolle}

\subsubsection{HE-Färbung mit dem Dako TechMate ${ }^{\mathrm{TM}}$ Horizon 500}

Dauer: 13 Minuten 46 Sekunden

Position der Reagenzien im Gerät:

1. Saugkissen 1

2. Saugkissen 2

3. Leitungswasser

4. Hematoxylin

5. $100 \%$ Ethanol

6. $1 \%$ iges Eosin

Tab.5: TechMate Horizon Maschinenprotokoll zur HE-Färbung

\begin{tabular}{|l|l|c|c|}
\hline Schritt & Reagenzien & $\begin{array}{l}\text { Start } \\
\text { h : min : sek }\end{array}$ & $\begin{array}{l}\text { Dauer } \\
\text { h min : sek }\end{array}$ \\
\hline $\mathbf{1}$ & Saugkissen 1 & $00: 00: 00$ & $00: 00: 20$ \\
\hline $\mathbf{2}$ & Wasser & $00: 00: 22$ & $00: 00: 10$ \\
\hline $\mathbf{3}$ & Saugkissen 1 & $00: 00: 35$ & $00: 00: 30$ \\
\hline $\mathbf{4}$ & Wasser & $00: 01: 08$ & $00: 00: 10$ \\
\hline $\mathbf{5}$ & Saugkissen 1 & $00: 01: 21$ & $00: 00: 45$ \\
\hline $\mathbf{6}$ & Hematoxylin & $00: 02: 09$ & $00: 04: 30$ \\
\hline $\mathbf{7}$ & Saugkissen 1 & $00: 06: 42$ & $00: 00: 30$ \\
\hline $\mathbf{8}$ & Wasser & $00: 07: 14$ & $00: 00: 10$ \\
\hline $\mathbf{9}$ & Saugkissen 2 & $00: 07: 26$ & $00: 00: 30$ \\
\hline $\mathbf{1 0}$ & Wasser & $00: 07: 58$ & $00: 00: 10$ \\
\hline $\mathbf{1 1}$ & Saugkissen 2 & $00: 08: 10$ & $00: 00: 30$ \\
\hline $\mathbf{1 2}$ & Wasser & $00: 08: 43$ & $00: 00: 10$ \\
\hline $\mathbf{1 3}$ & Saugkissen 2 & $00: 08: 55$ & $00: 00: 30$ \\
\hline $\mathbf{1 4}$ & Wasser & $00: 09: 27$ & $00: 00: 10$ \\
\hline $\mathbf{1 5}$ & Saugkissen 2 & $00: 09: 40$ & $00: 00: 30$ \\
\hline $\mathbf{1 6}$ & $100 \%$ Ethanol & $00: 10: 13$ & $00: 00: 10$ \\
\hline $\mathbf{1 7}$ & Saugkissen 2 & $00: 10: 27$ & $00: 00: 30$ \\
\hline $\mathbf{1 8}$ & Eosin & $00: 11: 01$ & $00: 01: 00$ \\
\hline $\mathbf{1 9}$ & Saugkissen 2 & $00: 12: 04$ & $00: 00: 30$ \\
\hline $\mathbf{2 0}$ & $100 \%$ Ethanol & $00: 12: 37$ & $00: 00: 10$ \\
\hline $\mathbf{2 1}$ & Saugkissen 2 & $00: 12: 50$ & $00: 00: 20$ \\
\hline $\mathbf{2 2}$ & $100 \%$ Ethanol & $00: 13: 13$ & $00: 00: 10$ \\
\hline $\mathbf{2 3}$ & Saugkissen 2 & $00: 13: 27$ & $00: 00: 20$ \\
\hline
\end{tabular}




\subsubsection{EnVision ${ }^{\mathrm{TM}}$-Färbung mit dem Dako TechMate ${ }^{\mathrm{TM}}$ Horizon 500}

Dauer: 1 Stunde 46 Minuten 50 Sekunden

Position der Reagenzien im Gerät:

1. Saugkissen 1

2. Saugkissen 2

3. Saugkissen 3

4. Saugkissen 4

5. Waschpuffer 1 (gepufferte Lösung mit Trägerprotein, Reinigungs- und Konservierungsmittel)

6. Waschpuffer 2 (gepufferte Lösung mit Reinigungs- und Konservierungsmittel)

7. Waschpuffer 3 (gepufferte Lösung mit Reinigungs- und Konservierungsmittel)

8. Waschpuffer 4 (Wasser mit Reinigungs- und Konservierungsmittel)

9. Antikörper

10. EnVision

11. Blockierungsreagenz

12. Chromogen-Substrat

13. Hematoxylin 
Tab.6: TechMate Horizon Maschinenprotokoll zur EnVision-Färbung

\begin{tabular}{|c|c|c|c|c|c|c|c|}
\hline Schritt & Reagenzien & $\begin{array}{l}\text { Start } \\
\text { h : min : sek }\end{array}$ & $\begin{array}{l}\text { Dauer } \\
\text { h: } \text { : min : sek }\end{array}$ & Schritt & Reagenzien & $\begin{array}{l}\text { Start } \\
\text { h : min : sek }\end{array}$ & $\begin{array}{l}\text { Dauer } \\
\text { h : min : sek }\end{array}$ \\
\hline 1 & Puffer 1 & 00:00:00 & $00: 00: 10$ & 38 & Saugkissen 2 & $01: 16: 40$ & 00:00:29 \\
\hline 2 & Saugkissen 1 & $00: 00: 13$ & 00:00:29 & 39 & Puffer 2 & $01: 17: 12$ & 00:00:10 \\
\hline 3 & Puffer 1 & $00: 00: 46$ & $00: 00: 10$ & 40 & Saugkissen 3 & $01: 17: 26$ & $00: 00: 29$ \\
\hline 4 & Saugkissen 1 & 00:01:00 & 00:00:29 & 41 & Puffer 3 & 01:17:59 & 00:00:10 \\
\hline 5 & Puffer 1 & 00:01:32 & 00:00:10 & 42 & Saugkissen 3 & $01: 18: 12$ & 00:00:29 \\
\hline 6 & Saugkissen 1 & $00: 01: 46$ & 00:00:29 & 43 & Puffer 3 & $01: 18: 45$ & 00:00:10 \\
\hline 7 & Puffer 1 & $00: 02: 19$ & 00:00:10 & 44 & Saugkissen 3 & 01:19:01 & $00: 00: 45$ \\
\hline 8 & Saugkissen 1 & $00: 02: 34$ & $00: 00: 45$ & 45 & Chromogen & $01: 19: 52$ & $00: 05: 00$ \\
\hline 9 & Antikörper & $00: 03: 25$ & $00: 25: 00$ & 46 & Saugkissen 3 & $01: 24: 56$ & 00:00:29 \\
\hline 10 & Saugkissen 1 & $00: 28: 28$ & $00: 00: 29$ & 47 & Puffer 3 & $01: 25: 28$ & $00: 00: 10$ \\
\hline 11 & Puffer 1 & $00: 29: 01$ & $00: 00: 10$ & 48 & Saugkissen 3 & $01: 25: 44$ & $00: 00: 45$ \\
\hline 12 & Saugkissen 1 & $00: 29: 15$ & 00:00:29 & 49 & Chromogen & $01: 26: 36$ & 00:05:00 \\
\hline 13 & Puffer 1 & $00: 29: 48$ & $00: 00: 10$ & 50 & Saugkissen 3 & $01: 31: 39$ & 00:00:29 \\
\hline 14 & Saugkissen 1 & $00: 30: 01$ & $00: 00: 29$ & 51 & Puffer 3 & $01: 32: 12$ & $00: 00: 10$ \\
\hline 15 & Puffer 1 & $00: 30: 34$ & $00: 00: 10$ & 52 & Saugkissen 3 & $01: 32: 28$ & $00: 00: 45$ \\
\hline 16 & Saugkissen 1 & $00: 30: 48$ & 00:00:29 & 53 & Chromogen & $01: 33: 19$ & 00:05:00 \\
\hline 17 & Puffer 1 & $00: 31: 20$ & $00: 00: 10$ & 54 & Saugkissen 3 & $01: 38: 23$ & 00:00:29 \\
\hline 18 & Saugkissen 1 & $00: 31: 34$ & $00: 00: 29$ & 55 & Puffer 3 & $01: 38: 55$ & $00: 00: 10$ \\
\hline 19 & Puffer 1 & $00: 32: 06$ & $00: 00: 10$ & 56 & Saugkissen 3 & 01:39:08 & 00:00:29 \\
\hline 20 & Saugkissen 2 & $00: 32: 22$ & 00:00:29 & 57 & Puffer 3 & 01:39:40 & 00:00:10 \\
\hline 21 & Blocking & $00: 32: 57$ & 00:02:30 & 58 & Saugkissen 4 & $01: 39: 56$ & 00:00:29 \\
\hline 22 & Saugkissen 2 & $00: 35: 33$ & $00: 00: 29$ & 59 & Hematoxylin & $01: 40: 31$ & 00:01:00 \\
\hline 23 & Blocking & 00:36:08 & $00: 02: 30$ & 60 & Saugkissen 4 & $01: 41: 34$ & 00:00:29 \\
\hline 24 & Saugkissen 2 & $00: 38: 44$ & 00:00:29 & 61 & Puffer 3 & 01:42:07 & 00:00:10 \\
\hline 25 & Blocking & $00: 39: 19$ & $00: 02: 30$ & 62 & Saugkissen 4 & $01: 42: 20$ & 00:00:29 \\
\hline 26 & Saugkissen 2 & $00: 41: 53$ & 00:00:29 & 63 & Puffer 3 & $01: 42: 52$ & $00: 00: 10$ \\
\hline 27 & Puffer 2 & $00: 42: 26$ & $00: 00: 10$ & 64 & Saugkissen 4 & $01: 43: 05$ & 00:00:29 \\
\hline 28 & Saugkissen 2 & $00: 42: 39$ & $00: 00: 29$ & 65 & Puffer 2 & $01: 43: 36$ & $00: 00: 10$ \\
\hline 29 & Puffer 2 & $00: 43: 12$ & 00:00:10 & 66 & Saugkissen 4 & $01: 43: 49$ & 00:00:29 \\
\hline 30 & Saugkissen 2 & $00: 43: 26$ & 00:00:29 & 67 & Puffer 2 & $01: 44: 21$ & 00:00:10 \\
\hline 31 & Puffer 2 & $00: 43: 59$ & $00: 00: 10$ & 68 & Saugkissen 4 & $01: 44: 34$ & 00:00:29 \\
\hline 32 & Saugkissen 2 & $00: 44: 14$ & $00: 00: 45$ & 69 & Puffer 4 & $01: 45: 07$ & $00: 00: 10$ \\
\hline 33 & EnVision & $00: 45: 04$ & $00: 30: 00$ & 70 & Saugkissen 4 & $01: 45: 21$ & $00: 00: 29$ \\
\hline 34 & Saugkissen 3 & 01:15:07 & 00:00:29 & 71 & Puffer 4 & $01: 45: 53$ & $00: 00: 10$ \\
\hline 35 & Puffer 2 & $01: 15: 40$ & $00: 00: 10$ & 72 & Saugkissen 4 & 01:46:07 & 00:00:29 \\
\hline 36 & Saugkissen 2 & $01: 15: 54$ & $00: 00: 29$ & 73 & Puffer 4 & $01: 46: 40$ & $00: 00: 10$ \\
\hline 37 & Puffer 2 & $01: 16: 26$ & 00:00:10 & & & & \\
\hline
\end{tabular}




\section{Danksagung}

Herrn Prof. Dr. R. Hustert danke ich für die Bereitschaft die externe Arbeit zu Betreuen und für sein Interesse an dieser Arbeit.

Mein besonderer Dank gilt Prof. Dr. H. Jarry für die freundliche Überlassung des Themas und die gute Betreuung. Die sorgfältige und kritische Beratung hat entscheidend bei der Fertigstellung dieser Arbeit geholfen.

Weiterhin danke ich auch Frau Prof. Dr. I. Balzer für die Hilfe bei der Entwicklung der einzelnen Nachweismethoden und der stets geduldigen und kompetenten Beratung, die maßgeblich zur Fertigstellung der Arbeit beigetragen hat.

Ebenfalls danken möchte ich Herrn Prof. Dr. W. Wuttke und allen Mitarbeitern der Abteilung Klinische und Experimentielle Endokrinologie, in der diese Arbeit durchgeführt wurde, für die gute Zusammenarbeit und die Hilfsbereitschaft. Besonderer Dank gilt hier Maria Metten für die Hilfe bei der Durchführung der Assays, Claudia Neitzel für die Unterweisung am TaqMan, sowie Annette Witt und Frank Hegemann für die Hilfe bei den Hirnstanzen und der Gewebeaufarbeitung.

Bei der Firma DakoCytomation und speziell bei Herrn Dr. Linder möchte ich für das kostenlose Überlassen des Dako TechMate ${ }^{\mathrm{TM}}$ Horizon Immunautostainers für die Dauer meiner Arbeit bedanken. Die Beratung von Herrn Linder und seinen Kollegen hat sehr zur Lösung verschiedenster Probleme beigetragen.

Weiter möchte ich mich auch bei der Abteilung Tiermedizin und Primatenhaltung des Deutschen Primatenzentrums (Göttingen) von Prof. Kaup für die Überlassung der Tiere bedanken, sowie für die Hilfe bei der Vesuchsdurchführung. In diesem Zusammenhang ein besonderes Danke an „mein Team“: Dr. Susanne Rensing (DPZ), Dr. Tamara Becker und Maria Metten.

Dr. Karin Bingger und Kristina Simonyan gilt mein ganz besonderer Dank für ihre Freundschaft, die moralische Unterstützung und praktischer Anregungen bei der Korrektur des Manuskriptes.

Schließlich möchte ich meinem Mann Clemens Patzlaff danken für seine liebevolle Unterstützung. Meinen Eltern, Johann und Ilse Köster, die mir das Studium ermöglichten und mich in jeder erdenklichen Weise immer unterstützten und bestärkten, gilt mein ganz besonderer Dank. Desweiteren danke ich auch meinen Geschwistern Angelika Müller und Michael Köster, sowie ihren Familien, für ihren Rückhalt in den vergangenen Jahren. 


\section{Lebenslauf}

\section{Christiane Köster-Patzlaff}

Geburtsdatum

18.09.1971

Geburtsort

Papenburg

Familienstand

verheiratet

\section{Schulbildung:}

$\begin{array}{ll}1977-1984 & \text { Grundschule und Orientierungsstufe } \\ & \text { Kirchschule Papenburg } \\ & \text { Realschule Papenburg } \\ & \text { Abschluß: Erweiterter Sekundarabschluß I } \\ & \text { Einjährige Berufsfachschule - Landwirtschaftliche und Haus- } \\ 1987-1988 & \text { wirtschaftliche Fachrichtung Berufsbildende Schulen Papenburg } \\ & \text { Mariengymnasium Papenburg } \\ & \text { Abschluß: Allgemeine Hochschulreife } \\ & \text { Studium an der Georg-August-Universität Göttingen } \\ & \text { Studiengang Biologie } \\ & \text { Abschluß: Diplom-Biologin } \\ & \text { Graduiertenkolleg „Perspektiven der Primatologie“ }\end{array}$

\section{Studium:}

09/97 - 02/99 Diplomarbeit bei Frau Prof. Dr. Podufal

III. Zoologisches Institut - Entwicklungsbiologie Arbeitsgruppe Insektenontogenese und Wirbeltierembryologie der GeorgAugust-Universität Göttingen

mit dem Thema: „Über die Entwicklung der Kauplatte bei Brachydanio rerio (HAMILTON-BUCHANAN)“ 
03/00 - 09/00 Dissertation im Rahmen des Graduiertenkollegs zunächst bei Prof. Dr. Kruse, Abteilung Phoniatrie und Pedaudiologie, Klinikum Göttingen, mit dem Thema: „Die Innervation der laryngealen Taschenfalte bei Macaca mulatta“

Abbruch aufgrund methodischer Probleme

09/00-12/02 Dissertation ebenfalls im Rahmen des Graduiertenkollegs bei Prof. Dr. Jarry, Abteilung Klin. und Exp. Endokrinologie, Klinikum Göttingen mit dem Thema: „Klonierung und Charakterisierung des Interleukin-1 $\beta$ Systems im Gehirn von Callithrix jacchus ${ }^{\text {“ }}$

\section{Berufliche Tätigkeiten:}

05/97-04/99 Tätigkeit als wissenschaftliche Hilfskraft bei Frau Prof. Dr. Podufal III. Zoologisches Institut - Entwicklungsbiologie Arbeitsgruppe Insektenontogenese und Wirbeltierembryologie der Georg-August-Universität Göttingen

07/02 - 12/02 Tätigkeit als wissenschaftliche Hilfskraft bei Prof. Dr. Jarry, Abteilung Klin. und Exp. Endokrinologie, Klinikum Göttingen

01/03 - 05/03 Tätigkeit als wissenschaftliche Mitarbeiterin bei Prof. Dr. Jarry, Abteilung Klin. und Exp. Endokrinologie, Klinikum Göttingen 